UNIVERSIDADE DE SÃO PAULO

INSTITUTO DE GEOCIÊNCIAS

\title{
MICROFÓSSEIS EM DEPÓSITOS QUATERNÁRIOS DE MEGAFAUNA NO NORDESTE DO BRASIL E SEU SIGNIFICADO PALEOAMBIENTAL
}

\section{VANDA BRITO DE MEDEIROS}

Tese apresentada ao Programa de PósGraduação em Geoquímica e Geotectônica, do Instituto de Geociências da Universidade de São Paulo, para obtenção do título de Doutor em Ciências

Orientador Prof ${ }^{\circ}$ Dr. Paulo Eduardo De Oliveira

SÃO PAULO

2019 

Autorizo a reprodução e divulgação total ou parcial deste trabalho, por qualquer meio convencional ou eletrônico, para fins de estudo e pesquisa, desde que citada a fonte.

Serviço de Biblioteca e Documentação do IGc/USP

Ficha catalográfica gerada automaticamente com dados fornecidos pelo(a) autor(a) via programa desenvolvido pela Seçāo Técnica de Informática do ICMC/USP

Bibliotecários responsáveis pela estrutura de catalogação da publicação: Sonia Regina Yole Guerra - CRB-8/4208 | Anderson de Santana - CRB-8/6658

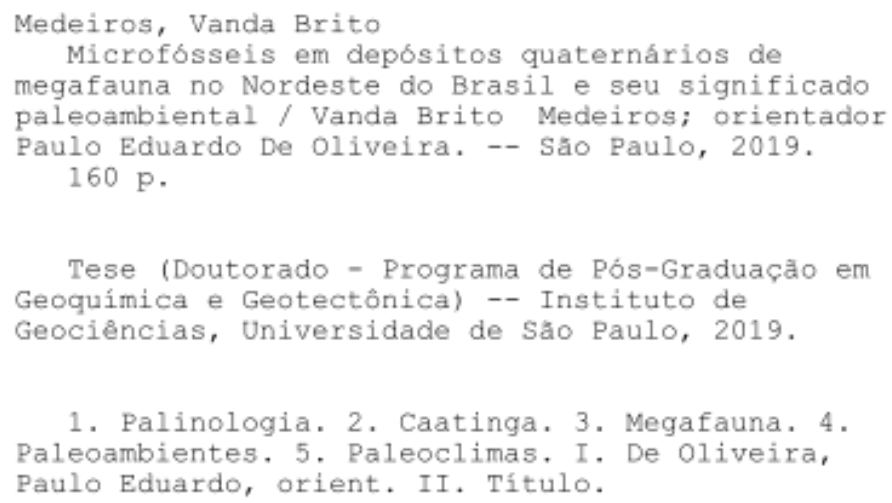


UNIVERSIDADE DE SÃO PAULO

INSTITUTO DE GEOCIÊNCIAS

\section{MICROFÓSSEIS EM DEPÓSITOS QUATERNÁRIOS DE MEGAFAUNA NO NORDESTE DO BRASIL E SEU SIGNIFICADO PALEOAMBIENTAL}

\section{VANDA BRITO DE MEDEIROS}

Orientador: Prof. Dr. Paulo Eduardo de Oliveira

TESE DE DOUTORADO

№ 601

COMISSÃO JULGADORA

Dr. Paulo Eduardo de Oliveira

Dr. Francisco William da Cruz Júnior

Dr. Gregório Cardoso Tápias Ceccantini

Dra. Alcina Magnólia Franca Barreto

Dr. Luiz Carlos Ruiz Pessenda

Dr. Vinícius Ribau Mendes

SÃO PAULO

2019 
Ao Sérgio e à Marina, que me dão forças todos os dias para continuar e me fazem ser uma pessoa melhor só por existirem na minha vida”

Dedico 


\section{AGRADECIMENTOS}

Agradeço a Deus pela oportunidade desta existência, pela saúde, conquistas e aprendizados.

Agradeço ao meu orientador, Prof. Dr. Paulo Eduardo de Oliveira, pela orientação, encorajamento, confiança, incentivo e amizade, assim como pelo companheirismo nos trabalhos de campo e pelos ensinamentos de vida, sempre transmitidos de forma espontânea.

À Prof ${ }^{a}$ Dra. Alcina Magnólia Franca Barreto, pelo acolhimento, amizade, alegria, companheirismo, disponibilidade em me auxiliar em todos os sentidos e acima de tudo, pelo grande carinho com que sempre me recebeu. Sem você este trabalho não seria possível.

Ao Prof. Dr. Édison Vicente de Oliveira, pelo desprendimento ao me auxiliar nos trabalhos de campo, pela amizade, pelas longas horas ao volante e por todo o ensinamento que me foi transmitido.

Ao Prof. Dr. Marcelo A. Teixeira de Oliveira, pelo suporte relativo ao testemunho do Vale do Catimbau.

Aos professores do Instituto de Geociências, com os quais tive contato e sempre me receberam e atenderam com boa vontade.

Ao Prof. Dr. Luiz Carlos Ruiz Pessenda pelo auxílio, orientação e esclarecimentos relacionados aos isótopos.

Aos funcionários do IGc/USP, pelo auxílio e apoio que facilitaram o desenvolvimento da minha pesquisa.

Aos amigos irmãos Judite, Rudney, Junior, Maicon, Cynthia, Jenny e Edilce pelo grande carinho, pelo convívio, amizade, auxílio, conversas, incentivo, desabafos e por fazerem minha vida mais alegre, mesmo nos momentos mais difíceis.

Aos demais amigos do Laboratório de Micropaleontogia do IGc/USP, Valeria, Thomas, Leonardo, Martin, Raphaella, Marina, Vinícius e todos os demais que passaram por lá ao longo destes anos e que os compartilharam comigo, sempre com otimismo, paciência e bom humor.

Aos amigos do Laboratório de Paleontologia do Departamento de Geologia da UFPE, Karoline, Yumi, Ludmila, Jefferson, Leonardo, Pétrius, Paula e Luana, por compartilhar conhecimentos, amizade e principalmente vários dias de campo em Capoeiras. 
Ao Sr. Elias, proprietário da Fazenda Zabelê em Capoeiras, por entender a importância do nosso trabalho e permitir que tivéssemos acesso ao depósito fossilífero em sua propriedade.

À Sra. Helenita Costa, Júnior, Dona Cida, Dona Eliana e Nenê, da Secretaria de Cultura do município de Capoeiras em Pernambuco, por nos acolher tão atenciosamente durante nossa estadia.

À Universidade de São Paulo, em especial ao Instituto de Geociências pelo suporte institucional que tornou possível o desenvolvimento desta pesquisa.

À Fundação de Amparo à Pesquisa do Estado de São Paulo (FAPESP), pelo apoio financeiro - Bolsa de Doutoramento - para a realização deste projeto (Processo FAPESP 2015/01782-8).

Ao CNPQ através do Edital MCT/CNPq/MEC/CAPES/FNDCT - Ação Tranversal/FAPS 47/2010 - SISBIOTA BRASIL ao Dr. Marcelo A. Teixeira de Oliveira, relacionado ao Vale do Catimbau.

À minha amada família, por tudo o que vocês significam para mim.

E finalmente agradeço a todas as demais pessoas que contribuíram para a execução deste projeto, direta ou indiretamente. 


\section{RESUMO}

O Nordeste brasileiro possui muitos depósitos com rico registro fossilífero da megafauna pleistocênica, ainda a serem estudados com relação ao habitat e hábitos alimentares destes megamamíferos. Desta forma, este trabalho teve por objetivo descrever o ambiente no qual estes animais habitavam durante o Pleistoceno Tardio; discutir o impacto das mudanças climáticas deste período na vegetação e as alterações ocorridas na base da cadeia trófica de representantes da megafauna; verificar se há evidências da interferência humana em sua extinção e averiguar a existência de corredores bióticos que teriam ligado a Mata Atlântica à Floresta Amazônica em momentos de maior umidade na região da Caatinga. Para tanto, foram realizadas análises micropaleontológicas em sedimentos coletados em tanques, contendo restos de megafauna e/ou em lagoas efêmeras, nos municípios de Afrânio, Buíque e São Bento do Una (Pernambuco) e em São João do Cariri (Paraíba) e em cálculos dentários destes animais. Sedimentos coletados em São Bento do Una, com aproximadamente 34.935 anos cal. AP, revelaram a presença de elementos de floresta úmida e fria, de forma descontínua até aproximadamente 19.000 anos cal. $\mathrm{AP}$, coincidindo com os eventos climáticos $\mathrm{H} 3$ e H2. Com o aquecimento do final do Pleistoceno, os elementos indicativos de clima frio desapareceram do registro, permanecendo alguns representantes da Amazônia e Floresta Atlântica. Os demais testemunhos cobrem o final do Pleistoceno, até o Holoceno. De forma geral, a umidade permanece, com a manutenção de uma floresta úmida até 6.000 anos cal. $\mathrm{AP}$, quando se inicia a fase de ressecamento e posterior implantação da Caatinga a partir de 4.900 anos cal. AP, sendo esta fase de seca marcada pela perda do sinal polínico, decorrente de hiato, em Buíque. O retorno da umidade, por volta de 2.000 anos cal. AP, foi caracterizado por chuvas torrenciais. Sinais de intervenção humana foram notados através da identificação de palmeiras a partir de 9.000 anos AP, assim como a presença de elementos introduzidos após a colonização. As análises realizadas nos cálculos dentários revelaram a presença de elementos vegetais característicos de floresta úmida e fria, com predomínio de ciclo fotossintético C3. Em suma, conclui-se que os megamamíferos pleistocênicos do Nordeste habitaram em um ecossistema não análogo à Caatinga atual; a presença de elementos vegetais atualmente restritos a ambientes mais úmidos e frios, indica a instalação de um corredor de trocas bióticas no passado; registros micropaleontológicos da Caatinga 
estão em sincronia e corroboram os estudos paleoclimáticos do Nordeste, no Quaternário Tardio. Não obstante, as alterações climáticas do Pleistoceno Tardio não foram responsáveis pelo estabelecimento da vegetação hiperxerófila, fato que ocorreu por volta de 4.900 anos cal. AP. Desta forma, a extinção da megafauna não ocorreu devido à inexistência de vegetação, mas o início do declínio pode ter ocorrido devido à configuração climática, em decorrência do aquecimento gradativo aliado ao aumento da pluviosidade, ao término do Último Máximo Glacial e durante o evento climático H1.

Palavras chave: Palinologia, Caatinga, Megafauna, Paleoambientes, Paleoclima 


\begin{abstract}
Northeastern Brazil has many deposits with rich fossil record of the Pleistocene megafauna, still to be studied in relation to the habitat and feeding habits of these megamammals. In this way, this work had the objective to describe the environment in which these animals inhabited during the Late Pleistocene; discuss the impact of climatic changes of this period on vegetation and the changes occurring at the base of the trophic chain of megafauna representatives; to verify if there is evidence of human interference in its extinction; and to investigate the existence of biotic corridors that would have connected the Atlantic Forest to the Amazon Forest in times of greater humidity in the Caatinga region. For that, micropaleontological analyses were performed in sediments collected in tanks containing megafauna remains and / or in ephemeral lagoons, in the cities of Afrânio, Buíque and São Bento do Una (Pernambuco state) and in São João do Cariri (Paraíba state) also in dental calculus of these animals. Sediments approximately 34,935 yrs cal. BP collected from São Bento do Una, revealed the presence of elements of wet and cold forest, discontinuously approximately 19,000 yrs cal. BP, coinciding with $\mathrm{H} 3$ and $\mathrm{H} 2$ climatic events. With the warming of the late Pleistocene, the elements indicative of cold weather disappeared from the registry, remaining some representatives of the Amazon and Atlantic Forest. The other core samples covered the late Pleistocene, up to the Holocene. In general, the humidity remains, with the maintenance of a rainforest up to 6,000 yrs cal. BP, when the dry season begins and the posterior Caatinga implantation after 4,900 yrs cal. BP, being this drought phase marked by the loss of the pollen signal, due to hiatus in Buíque. The return of humidity, about 2,000 yrs cal. BP, was characterized by torrential rains. Signs of human intervention were noted through the identification of palms from 9,000 yrs cal. BP, as well as the presence of elements introduced after colonization. The analyses performed in dental calculus revealed the presence of vegetal elements characteristic of wet and cold forest, with predominance of C3 photosynthetic cycle. In sum, it is concluded that the Pleistocene megamammals of the northeast inhabited an ecosystem not analogous to the current Caatinga; the presence of plant elements currently restricted to more wet and cold environments, indicates the installation of a corridor of biotic exchanges in the past; micropaleontological records of the Caatinga are in synchrony and corroborate the paleoclimatic studies of the Northeast in the Late Quaternary. Nevertheless, climatic
\end{abstract}


changes of Late Pleistocene were not responsible for the establishment of hyperxerophilic vegetation, a fact that occurred around 4,900 yrs cal. BP. Thus, the extinction of the megafauna did not occur due to the lack of vegetation, but the beginning of the decline may have occurred as a result of the climatic configuration, due to the gradual warming associated with the increase of rainfall, at the end of the Last Glacial Maximum and during the climatic event $\mathrm{H} 1$.

Keywords: Palynology, Caatinga, Megafauna, Paleoenvironments, Paleoclimate 


\section{SUMÁRIO}

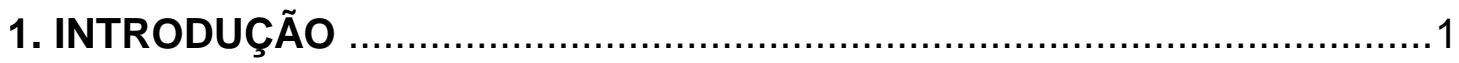

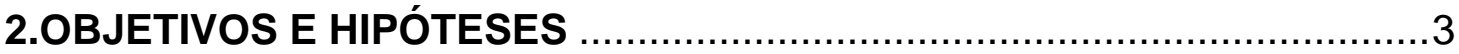

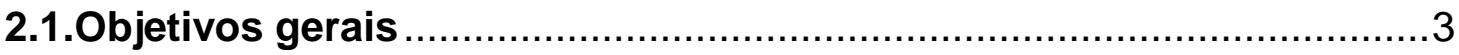

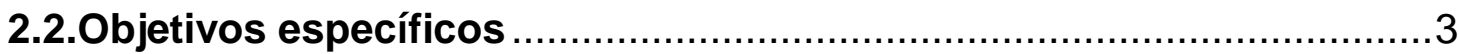

2.2.1.Núcleo paleovegetacional .....................................................

2.2.2.Núcleo paleontológico .....................................................

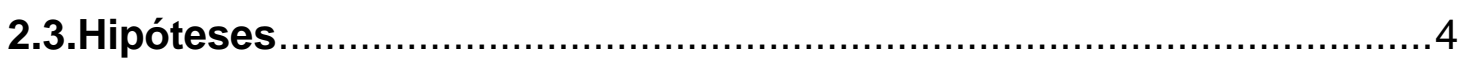

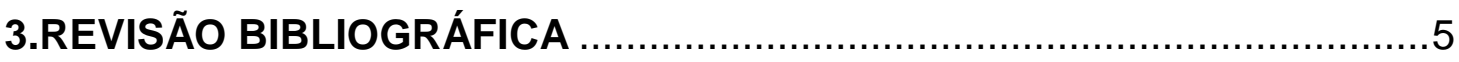

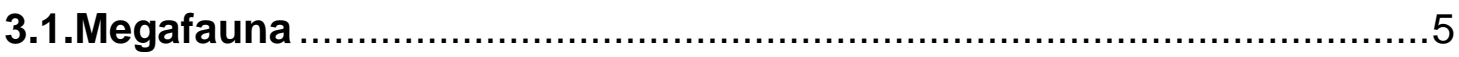

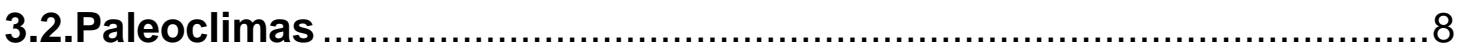

3.2.1.O clima do Nordeste brasileiro no Quaternário Tardio.....................8

3.2.2.Paleoclimas e seus indicadores..............................................9

3.2.3.Mudanças climáticas no NEB desde o Pleistoceno Tardio .............11

3.3.Microfósseis e isótopos estáveis ............................................... 12

3.3.1.Palinologia ............................................................... 12

3.3.2.Diatomáceas .................................................................... 14

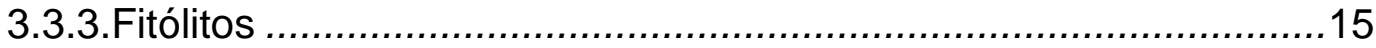

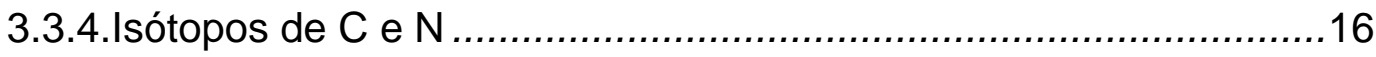

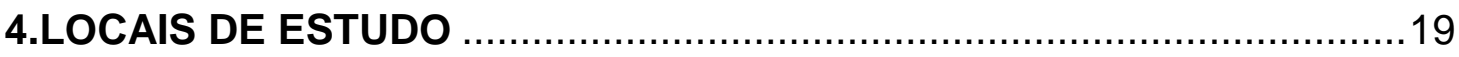

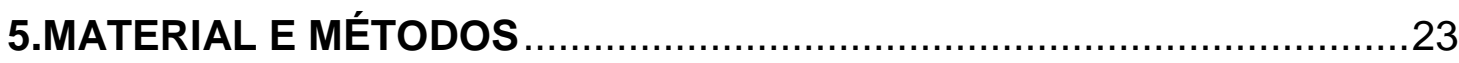

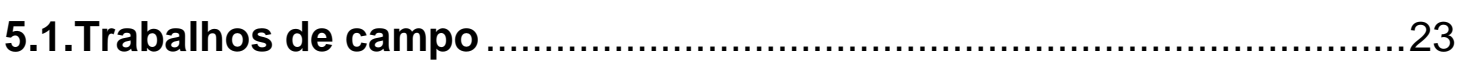

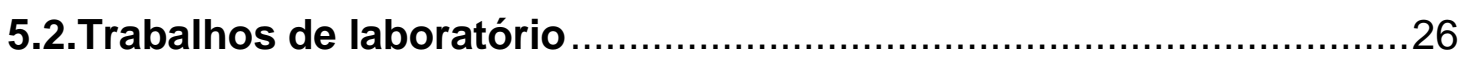

5.2.1.Protocolos micropaleontológicos ............................................26

5.2.2.Análises isotópicas e elementares de carbono e nitrogênio ...........30

6.VALE DO CATIMBAU - BUÍQUE - PE ......................................... 33

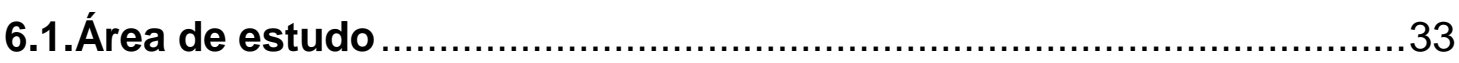

6.1.1.Caracterização geográfica ...................................................33

6.1.2.Caracterização geológica e geomorfológica ...............................33

6.1.3.Caracterização climática e vegetacional..................................33

6.2.Trabalho de campo .......................................................... 34

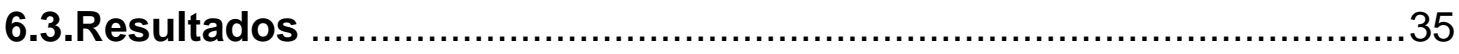

6.3.1.Litologia e datação........................................................ 35

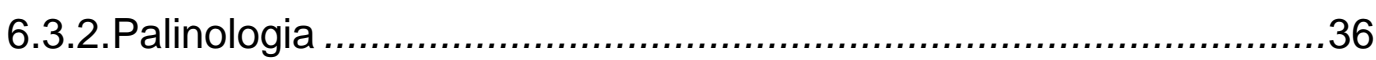

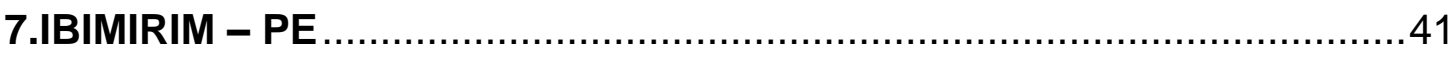

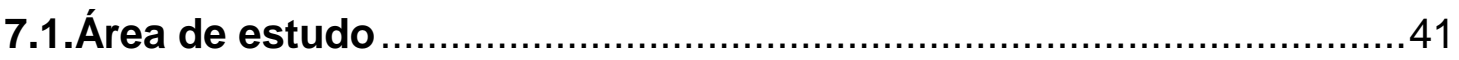


7.1.1.Caracterização geográfica, geomorfológica e geológica................. 41

7.1.2. Caracterização climática e vegetacional ...................................... 41

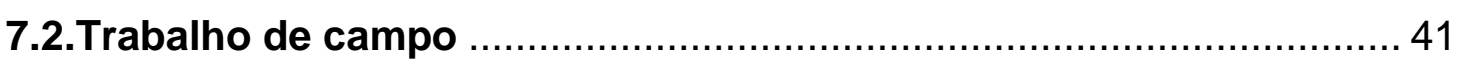

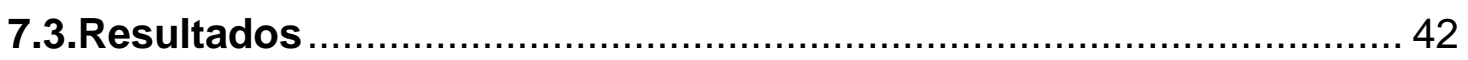

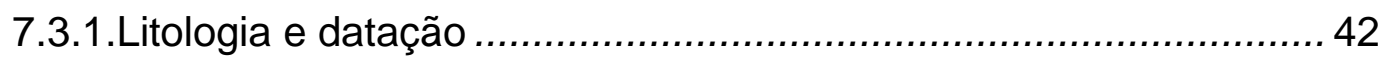

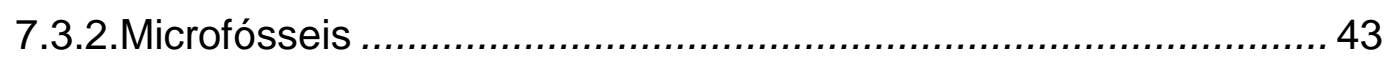

8.CAPOEIRAS - PE

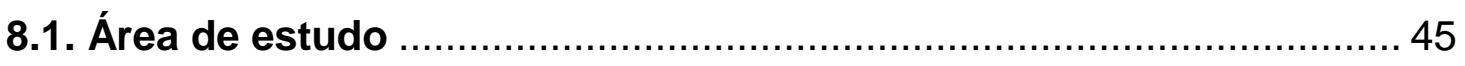

8.1.1. Caracterização geográfica, geomorfológica e geológica................ 45

8.1.2. Caracterização climática e vegetacional ...................................... 45

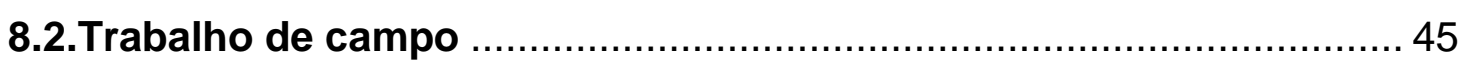

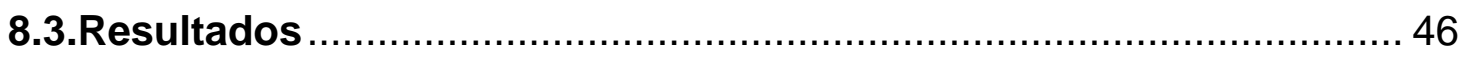

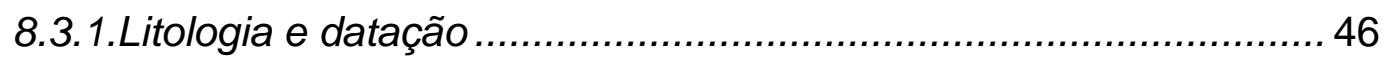

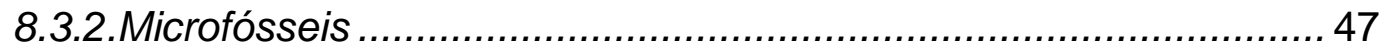

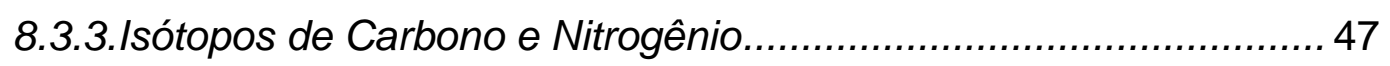

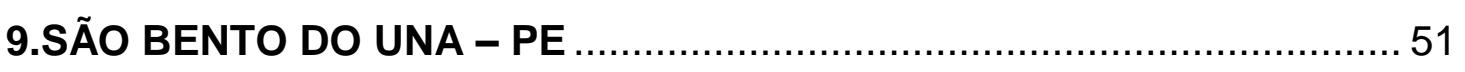

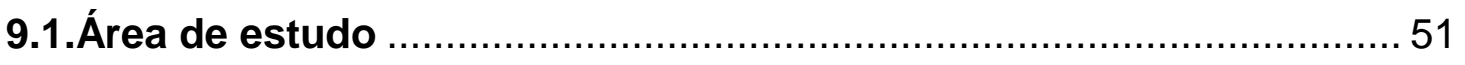

9.1.1. Caracterização geográfica, geomorfológica e geológica................ 51

9.1.2. Caracterização climática e vegetacional ...................................... 51

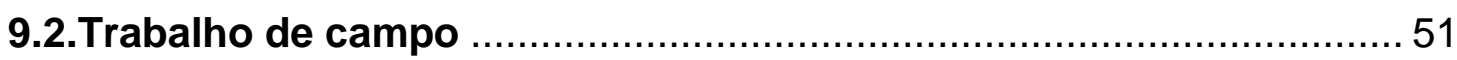

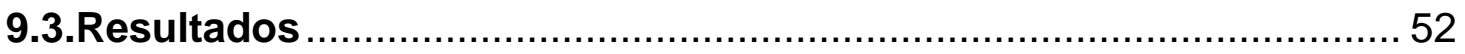

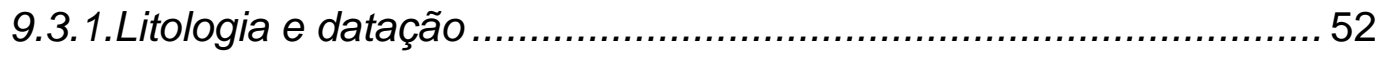

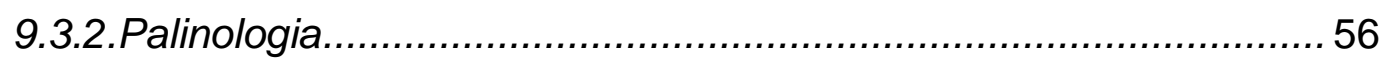

9.3.3. Isótopos de Carbono e Nitrogênio................................................. 60

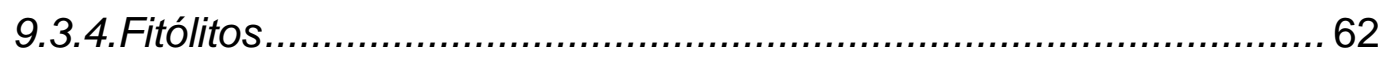

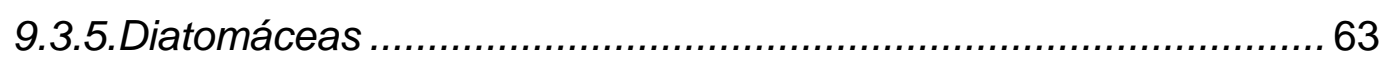

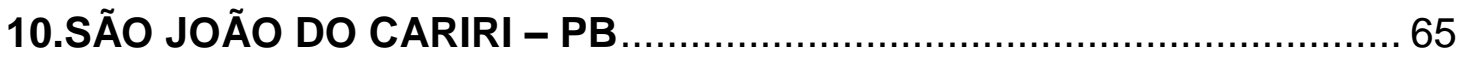

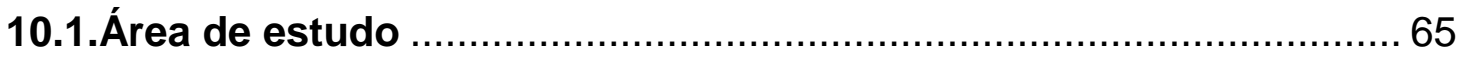

10.1.1.Caracterização geográfica, geomorfológica e geológica............... 65

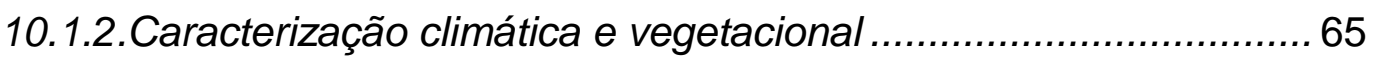

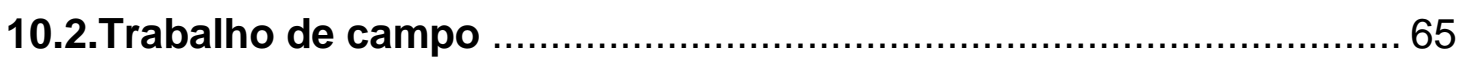

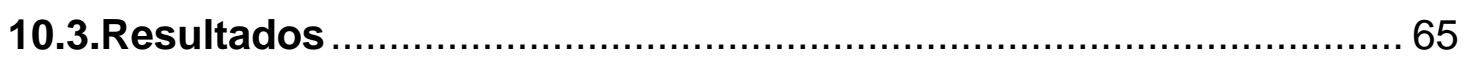

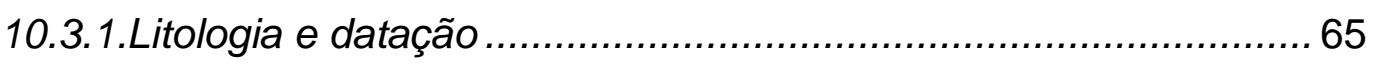

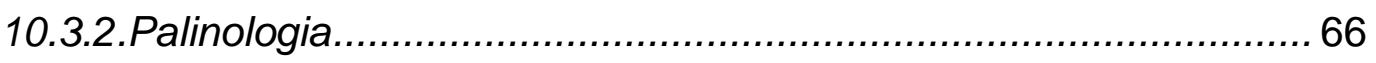

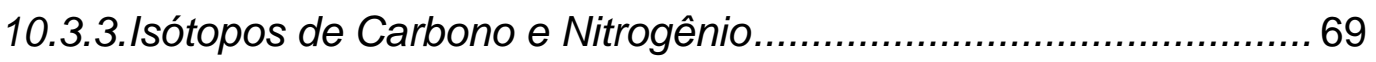

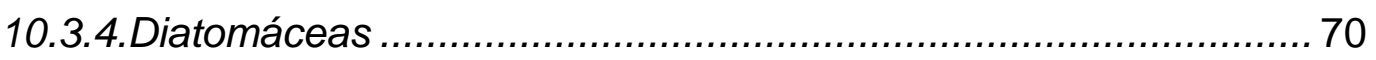

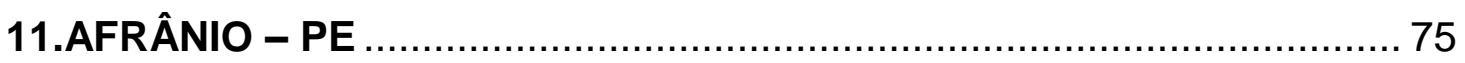




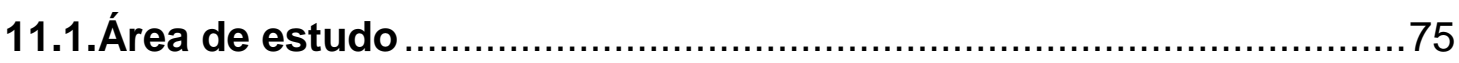

11.1.1.Caracterização geográfica, geomorfológica e geológica ..............75

11.1.2. Caracterização climática e vegetacional.....................................75

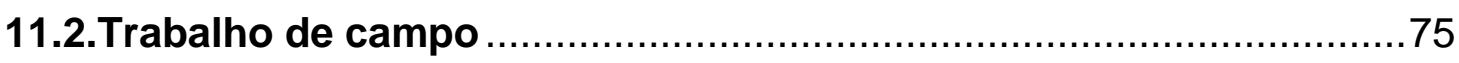

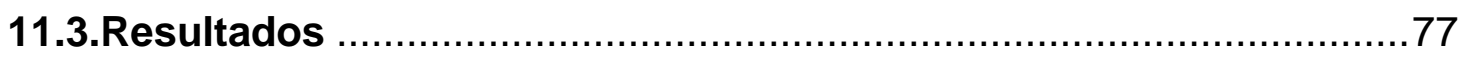

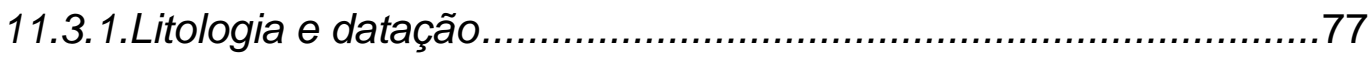

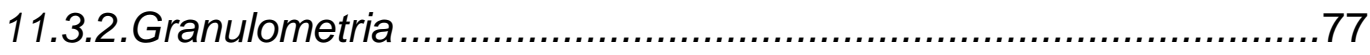

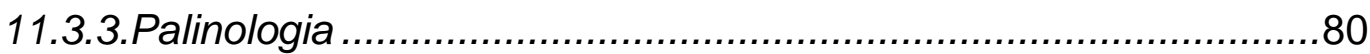

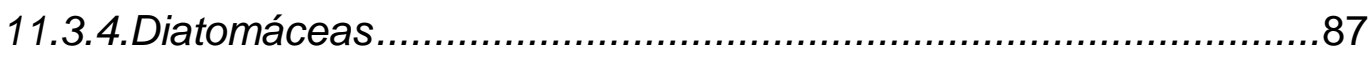

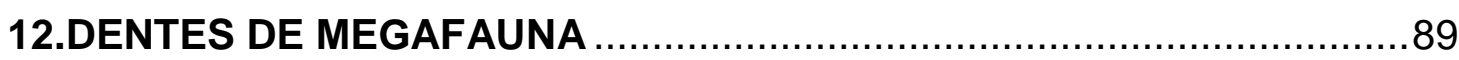

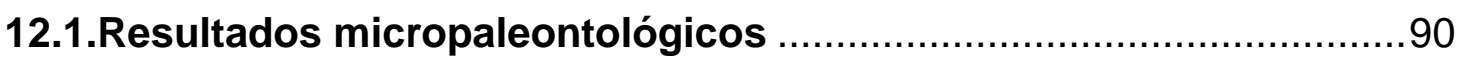

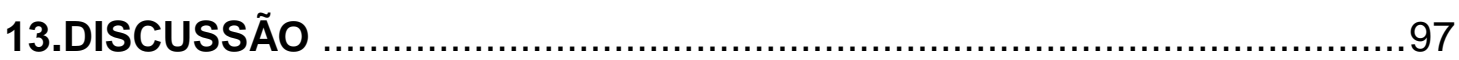

13.1.Micropaleontologia de sedimentos ricos em restos de Megafauna do NEB e de outros depósitos estudados ............................................................

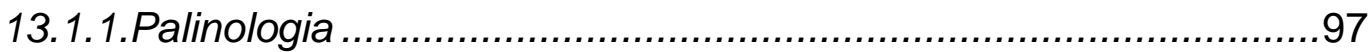

13.1.2. Diatomáceas e espículas de esponjas ...................................105

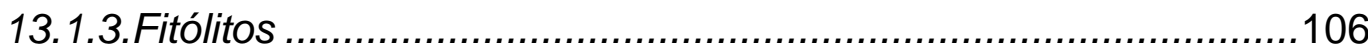

13.2.Fisionomia da vegetação e sua relação com as variações climáticas do Pleistoceno Tardio e Holoceno 107

13.2.1.Pleistoceno Tardio - Transição Pleistoceno/Holoceno................107

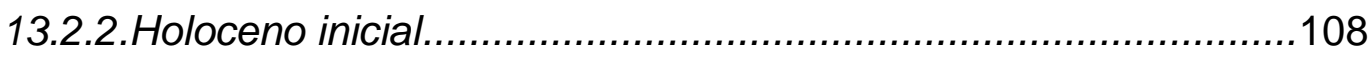

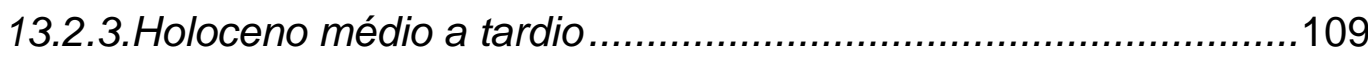

13.3.Micropaleontologia de cálculos dentários de Stegomastodon ......110

13.4.Integração de dados micropaleontológicos e paleontológicos......111

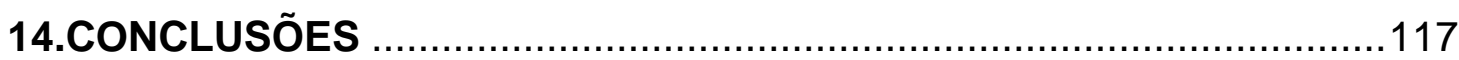

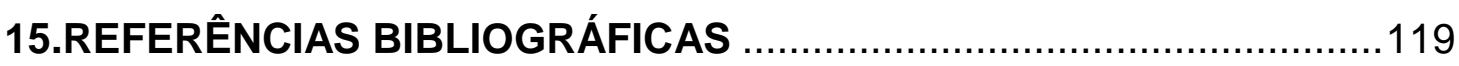




\section{LISTA DE FIGURAS}

Figura 1. Mapa de localização dos pontos de estudo, em relação a estudos paleoclimáticos anteriormente realizados, mostrando a distribuição da vegetação do NEB, elaborado em $Q$ GIS 2.18 Las Palmas software. Círculos amarelos - locais estudados: 1 - Vale do Catimbau, Buíque (PE); 2 - Ibimirim (PE); 3 - Capoeiras (PE); 4 - São Bento do Una (PE); 5 - São João do Cariri (PB); 6 -Afrânio (PE). Círculos brancos - estudos referenciados: 1 - Rio Icatu (De Oliveira et al., 1999); 2 - Cavernas Diva de Maura e Torrinha (Novello et al., 2014); 3 PARNA, FLONA e REBIO (Pessenda et al., 2010); 4 - Rio Grande do Norte (Cruz et al., 2009); 5 - Serra do Maranguape (Montade et al., 2014); 6 - GeoB 3104-1 (Behling et al., 2010); 7 Rio Parnaíba (Mendes, 2016).

Figura 2. Mapa geral de relevo da região estudada, com os pontos de coleta de sedimentos.

Figura 3. Distribuição média de precipitação sazonal (em $\mathrm{mm}$ ). Entre dezembro e fevereiro à esquerda e entre março e maio à direita. Os números se referem aos locais de estudo. Modificado de (Cruz et al., 2009)

Figura 4. Imagem da prospecção em lagoa seca, no município de Ibimirim - PE, quando foi avaliada a textura dos sedimentos, em fevereiro de 2014. Fotos: Paulo E. de Oliveira.

Figura 5. Imagens das prospecções em cacimba localizada no município de São Bento do Una, em junho de 2014. Foto: Paulo E. de Oliveira.

Figura 6. Imagem de prospecção em cacimba localizada no município de Capoeiras - PE, em setembro de 2015. Foto: Vanda Medeiros

Figura 7. Imagens de prospecções realizadas nos municípios de Cabaceiras e Boa Vista PB, em setembro de 2015. a, b, c) Sobre lajedos; d, e, f) em lagoas secas. Fotos: Vanda Medeiros.

Figura 8. Imagens de prospecções realizadas no estado da Paraíba em março de 2016. a) sobre o Lajedo da Gangorra no município de Cabaceiras - PB; b) em região de ecótono Caatinga/Mata Atlântica em Cabaceiras - PB; c) em brejo de altitude no município de Monteiro - PB. Fotos: Vanda Medeiros 25

Figura 9. Tentativa de coleta de sedimentos com o amostrador Livingstone em lagoa localizada no município de Afrânio - PE, em março de 2016.

Figura 10. Subamostragem de testemunho em amostras de $1 \mathrm{~cm}^{3}$. Fotos: Vanda Medeiros

Figura 11. Vista de aproximação do Vale do Catimbau, com a chapada ao fundo, composta por arenitos fluviais da Bacia sedimentar do Jatobá (Paleozoico ao Mesozoico). Foto: Paulo E. de Oliveira.

Figura 12. Coleta de sedimentos no Vale do Catimbau com testemunhador Russo. Fotos: Paulo E. de Oliveira. 
Figura 13. Modelo de idade obtido através do Software Oxcal 4.3 (Ramsey, 2008), com a presença de hiato deposicional entre ca. 6.000 e 2.000 anos cal. AP.

Figura 14. Diagrama polínico de porcentagem, do Vale do Catimbau, com os táxons mais representativos e soma de categorias.

Figura 15. Diagrama polínico de concentração de categorias (x 1000), do Vale do Catimbau.

Figura 16. Lagoa do Puiú, situada no município de lbimirim (PE). Foto: Vanda B. de Medeiros

Figura 17. Coleta de sedimentos na Lagoa do Puiú, município de Ibimirim (PE). a) Trincheira escavada; b) Coleta de testemunho com amostrador Linvigstone. Fotos: Vanda Medeiros e Alcina F. Barreto respectivamente 433

Figura 18. Seção estratigráfica com localização das amostras coletadas na Lagoa do Puiú lbimirim - PE. 444

Figura 19. Cacimba localizada no município de Capoeiras (PE), com lâmina d'água em setembro/2015. Foto: Vanda B. de Medeiros. 46

Figura 20. Cacimba localizada na Fazenda Currais Queimados, em Capoeiras (PE). a) Local onde foi realizada a escavação. $O$ traçado na imagem reflete a extensão da área de ocorrência de sedimentos na cacimba; b) Camada contendo ossadas de megafauna e seus sedimentos correlatos. Fotos: Vanda B. de Medeiros 477

Figura 21. Coluna estratigráfica do ponto de coleta em Capoeiras - PE. 488

Figura 22. Perfil de COT, NT e C/N ao longo do testemunho da localidade de Capoeiras - PE

Figura 23. Cacimba localizada no município de São Bento do Una (PE). a) Foto de jul/2014, época em que estava cheia, após período de chuvas; b) Foto de set/2015, em período de seca, quando foi feita a coleta de sedimentos no local. Fotos: Paulo E. de Oliveira e Vanda B. de Medeiros, respectivamente 52

Figura 24. Trincheira escavada no município de São Bento do Una. O colchete em preto destaca a laje de arenito calcífero, com $70 \mathrm{~cm}$ de espessura e a seta aponta a superfície dos sedimentos coletados. Foto: Paulo E. de Oliveira.

Figura 25. Perfil coletado no povoado de Tamanduá de Cima, no município de São Bento do Una - PE. a) Seção estratigráfica da cacimba, com a sinalização dos locais de amostragem para análises palinológicas e idades calibradas; b) Cacimba após a limpeza do perfil e coleta de amostras. .54

Figura 26. Modelo de idade, obtido através do pacote Rbacon (Blaauw e Christen, 2011). 55 
Figura 27. Cacimba em São Bento do Una. a) Local escavado para a coleta de sedimentos; b) Fácie similar ao ponto escavado, na mesma localidade, com a visualização da camada de argila sob o arenito calcífero, cheia de gretas, em período de seca. Fotos: Vanda B. de Medeiros.

Figura 28. Diagrama polínico de porcentagem dos elementos arbóreos da cacimba de São Bento do Una - PE. Área hachurada equivale a exagero de 10X.

Figura 29. Diagrama polínico de porcentagem de elementos herbáceos terrestres e aquáticos da cacimba de São Bento do Una - PE. Área hachurada equivale a exagero de 10X....55860

Figura 31. Diagrama polínico de concentração de categorias da cacimba de São Bento do Una - PE

Figura 32. Distribuição de valores de COT, NT, C/N, $\delta^{13} \mathrm{C}$, concentração de elementos arbóreos, micropartículas carbonizadas e grãos de pólen danificados, ao longo do perfil sedimentar de São Bento do Una - PE.

Figura 33. Diagrama de porcentagem de fitólitos, da cacimba de São Bento do Una - PE. As zonas foram obtidas pelo dendrograma do subprograma CONISS para a palinologia.

Figura 34. Perfil coletado em São João do Cariri - PB. a) Local de coleta, circulado com matacões; b) Trincheira escavada para amostragem. Fotos: Vanda B. de Medeiros.

Figura 35. Modelo de idade calibrado construído com pacote Rbacon (Blaauw e Christen, 2011), para o testemunho de São João do Cariri - PB.

Figura 36. Diagrama polínico de elementos arbóreos, do testemunho de São João do Cariri PB. Área hachurada com exagero de 5X.

Figura 37. Diagrama polínico de porcentagem de ervas terrestres e aquáticas, do testemunho de São João do Cariri - PB. Área hachurada com exagero de 5X.

Figura 38. Diagrama polínico de porcentagem de criptógamas aquáticas, pteridófitas e algas do testemunho de São João do Cariri - PB.

Figura 39. Diagrama polínico de porcentagem de categorias do testemunho de São João do Cariri - PB.

Figura 40. Diagrama polínico de concentração de categoria, inclusive das micropartículas carbonizadas, cujo gráfico representa sua concentração total, para o testemunho de São João do Cariri - PB.

Figura 41. Diagrama de resultados de isótopos, associados à concentração de categorias de árvores e arbustos, ervas terrestres e aquáticas, soma polínica total, grãos danificados e micropartículas carbonizadas $>100 \mu \mathrm{m}$, para o testemunho de São João do Cariri - PB. .. 73 
Figura 42. Tentativa de coleta de sedimentos lacustres com amostrador Livingstone realizada em março de 2016, em coluna d'água de 1,80 m, na Lagoa Comprida, em Afrânio - PE. Foto: Alcina F. Barreto 76

Figura 43. Trincheira escavada em Afrânio - PE. a) Panomorama geral da lagoa seca, com a trincheira escavada no centro; b) Vista frontal da trincheira, com $260 \mathrm{~cm}$ de profundidade, até o embasamento cristalino. Fotos: Vanda B. de Medeiros 76

Figura 44. Seção estratigráfica do perfil escavado na Lagoa Comprida, em Afrânio - PE, com a sinalização de amostragem para as análises....

Figura 45. Representação gráfica dos dados granulométricos dos sedimentos da Lagoa Comprida, Afrânio - PE. Areia, silte e argila são apresentados em porcentagem e diâmetro médio em micrômetros..

Figura 46. Diagrama polínico de porcentagem de elementos arbóreos e de palmeiras do testemunho de Afrãnio - PE.

Figura 47. Diagrama polínico de porcentagem de ervas terrestres, aquáticas e de lianas do testemunho de Afrãnio - PE.

Figura 48. Diagrama polínico de porcentagem de Azolla, algas e pteridófitas do testemunho de Afrãnio - PE.

Figura 49. Diagrama polínico de porcentagem de categorias do testemunho de Afrãnio - PE.

Figura 50. Diagrama polínico de concentração de categorias do testemunho de Afrãnio - PE.

Figura 51. Fragmentos de molares de Stegomastodon. a) molar coletado na Fazenda Currais Queimados, em Capoeiras (PE); b, c, d, e) coleção científica da UFPE. Fotos: Vanda Medeiros.

Figura 52. Dente molar de Stegomastodon waringi, coletado no município de Capoeiras - PE. A seta indica o orifício presente no dente, de onde foi coletado material para análise, além do cálculo. Foto: Vanda Medeiros.

Figura 53. Microfotografia do campo de visão de lâmina da amostra $B$, molar fragmentado coletado no município de Brejo da Madre de Deus - PE, onde se percebe que não há microfósseis de valor diagnóstico. Foto: Maicon Alicrin. 92

Figura 54. Diagrama de porcentagem e concentração de agrupamentos de microfósseis identificados em cálculos dentários de quatro molares ou fragmentos de molares de Stegomastodon waringi. .94

Figura 55. Mapa de relevo do ponto de coleta em São Bento do Una - PE, onde foram identificados grãos de pólen da conífera Podocarpus, hoje restrita a Brejos de Altitude no NEB. 
A altitude desta localidade sugere que este local pode ter apresentado a configuração climática de um Brejo de Altitude no passado.

Figura 56. Imagem de satélite da turfeira localizada no Vale do Catimbau, inserida dentro de um anfiteatro rochoso, no meio da Serra de São José. Percebe-se uma camada de umidade no sopé da serra, margeando a caatinga. A estrela sinaliza o local da amostragem. Imagem obtida de Google Earth., em 04/02/2018 101

Figura 57. Mapa de relevo da região da Bacia Escola, com a localização do ponto de coleta. a) Mapa do Brasil com a indicação do estado da Paraíba; b) Mapa da Paraíba, com indicação do município de São João do Cariri; c) Indicação do ponto de coleta, próximo à rede de drenagem. 102

Figura 58. Imagem de satélite com a demarcação do ponto de coleta, em formato de lagoa. Dado referente a 2014. Fonte Google Earth. Acesso: 21/01/2019.

Figura 59. Quadro resumo dos perfis analisados, em comparação com registros paleoclimáticos do último período glacial, do Nordeste do Brasil. As barras de cor cinza destacam os eventos $\mathrm{H}$.. Erro! Indicador não definido. 


\section{LISTA DE TABELAS}

Tabela 1. Relação de amostras encaminhadas para análises de carbono e nitrogênio, com a descrição dos sedimentos correlatos 31

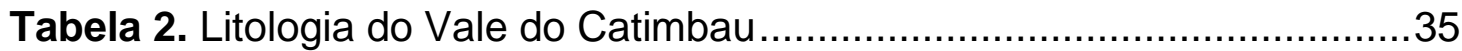

Tabela 3. Idades radiocarbônicas do testemunho do Vale do Catimbau.........35

Tabela 4. Idades radiocarbônicas do perfil sedimentar de São Bento do Una PE

Tabela 5. Idades radiocarbônicas de sedimentos coletados em São João do Cariri - PB 66

Tabela 6. Idades radiocarbônicas dos sedimentos coletados no município de Afrânio - PE .79

Tabela 7. Relação das amostras analisadas, número de código na coleção científica do Laboratório de Paleontologia do Departamento de Geologia da UFPE e município de origem. 90

Tabela 8. Dados de porcentagem e concentração de palinomorfos e microfósseis silicosos encontrados em cada amostra analisada 91

Tabela 9. Classificação quanto ao hábito dos táxons identificados, com altura mínima e sua fração $\delta^{13} \mathrm{C}$. As referências estão relacionadas abaixo. .95

Tabela 10. Distribuição dos táxons de diatomáceas identificados em cada localidade de estudo. 106 


\section{INTRODUÇÃO}

O Nordeste do Brasil (NEB), dentro do âmbito da Paleontologia, se destaca por possuir uma grande quantidade de depósitos como tanques/cacimbas ou lagos com ricos registros fossilíferos da megafauna pleistocênica, os quais foram estudados principalmente para responder questões paleontológicas (Alves 2007; Porpino, Fernicola, e Bergqvist 2009; Araújo-Júnior e Porpino 2011; Dantas et al. 2013; Oliveira, Porpino, e Silva 2013). No entanto, até o momento, não foram realizados estudos sobre o conteúdo micropaleontológico destes depósitos, apesar de microfósseis, tais como grãos de pólen, esporos de pteridófitas e fungos, zigósporos de algas, diatomáceas, fitólitos e micropartículas carbonizadas, serem excelentes bioindicadores e terem grande utilidade em estudos de reconstituição paleoambiental (Traverse, 2005). Entre as vantagens desse tipo de análise, estão seu pequeno tamanho, grande quantidade de organismos e sua capacidade de preservação, especialmente sob condições anóxicas (Salgado-Labouriau, 1994; Piperno, 2006).

Estudos realizados sobre a megafauna, em geral, levantam grandes questões ainda não totalmente respondidas tais como a relação desses animais com o meio ambiente, especialmente a vegetação e o clima; a época da extinção, comumente determinada na transição Pleistoceno/Holoceno a ca. 12.000 anos AP (Antes do Presente) (van Geel et al., 2011; Barnosky et al., 2016) e a contribuição do homem nesta extinção (Grayson 1984; Koch e Barnosky 2006; Dantas et al. 2014); rotas de migrações destes animais, desde altas latitudes do continente sul-americano até a América do Norte e vice-versa (MacFadden, 2006). Estas trocas bióticas implicam na existência de corredores ou áreas de contato e alguns estudos palinológicos apoiam a hipótese de rotas vegetacionais entre diferentes ecossistemas brasileiros para o Quaternário Tardio (De Oliveira, Barreto, e Suguio 1999; Behling et al. 2000).

Recentemente, com o desenvolvimento de estudos paleoambientais geoquímicos no NEB (Cruz et al., 2009; Novello et al., 2012), é necessária a contextualização dos dados paleontológicos sob a luz dos dados climáticos, especialmente os gerados pelos dados de $\delta^{18} \mathrm{O}$ em espeleotemas. Um consenso que predomina na literatura atual relaciona a expansão de geleiras no Hemisfério Norte $(\mathrm{HN})$, durante os eventos climáticos Heinrich, com climas mais úmidos no Hemisfério Sul, principalmente na região onde hoje predomina a Caatinga (Wang et al. 2004; Cruz et al. 2009; Barreto 2010; Cheng et al. 2012). Este paradigma tem apoio em registros 
paleobotânicos e palinológicos (Auler 1999; De Oliveira, Barreto, e Suguio 1999; Cristalli 2006), que sugerem a substituição de vegetação hiperxerófila e xerófila por floresta tropical durante fases úmidas dentro do último ciclo glacial. É importante ressaltar que dentre todos os ecossistemas modernos brasileiros, a Caatinga é o menos conhecido em termos de sua história ambiental, especialmente derivada da análise palinológica.

Desta forma, o presente estudo tem a finalidade de extrair e quantificar microfósseis em depósitos ricos em restos de megafauna em algumas áreas do NEB para reconstituir a paleovegetação, o paleoclima e testar hipóteses vegetacionais e climáticas, incluindo, se possível, aquelas relacionadas ao hábito alimentar e nicho ecológico desses animais e possivelmente contribuir com o entendimento sobre sua extinção. 


\section{OBJETIVOS E HIPÓTESES}

\subsection{Objetivos gerais}

* Contribuir para o conhecimento sobre a paleovegetação do NEB.

* Integrar dados micropaleontológicos com dados paleontológicos disponíveis na literatura para a região estudada.

\subsection{Objetivos específicos}

Os objetivos específicos são organizados em dois núcleos distintos: Núcleo paleovegetacional e Núcleo paleontológico, a seguir.

\subsubsection{Núcleo paleovegetacional}

* Analisar o conteúdo micropaleontológico de sedimentos lacustres e de tanques, ou seja, de corpos lacustres preenchidos por sedimentos ricos em restos de animais pertencentes à megafauna pleistocênica;

* Determinar a composição florística, ao nível de gênero, e inferir o tipo vegetacional, assim como as variações climáticas quaternárias dos locais estudados, inseridos atualmente no ecossistema Caatinga;

* Inferir mudanças vegetacionais em ecótonos Cerrado-Caatinga em região semi-árida de Pernambuco e Paraíba, em função de mudanças climáticas e/ou atividades antrópicas, através de análise micropaleontológica.

\subsubsection{Núcleo paleontológico}

- Analisar o conteúdo micropaleontológico encontrado em cálculos dentários presentes em fósseis de animais da megafauna;

* Identificar a composição florística predominante que sustentava alguns mamíferos pleistocênicos nas localidades estudadas, ou através da análise de microvestígios encontrados em cálculos dentários da megafauna do NEB; 


\subsection{Hipóteses}

Esta pesquisa é estruturada pelas seguintes hipóteses:

H1 - Evidências palinológicas, a partir do exame de sedimentos e/ou de dentição de grandes animais extintos, apoiam o cenário ambiental de convivência da megafauna pleistocênica com clima e vegetação florestal mais úmida que o presente.

H2 - Mudanças climáticas na transição Pleistoceno/Holoceno alteraram a composição da vegetação, com redução de elementos vegetais e estabelecimento da paisagem atual e, consequentemente, reduziram a base da cadeia trófica disponível à Megafauna.

H3 - A existência de corredores bióticos, instalados em momentos de maior umidade, possibilitou a interligação da Floresta Amazônica à Mata Atlântica, via Caatinga, por onde ocorreram trocas florísticas, que por sua vez explicam a presença relictual de táxons vegetais na Caatinga moderna.

H5 - O sinal vegetacional/climático obtido em sedimentos de Pernambuco e Paraíba mostram-se sincrônicos às mudanças e alterações registrados em outros locais do NEB, disponíveis na literatura. 


\section{REVISÃO BIBLIOGRÁFICA}

\subsection{Megafauna}

Fósseis de mamíferos do Quaternário no Brasil são reportados em praticamente todas as regiões, sendo que a maior diversidade está presente na região sudeste (Bergqvist e Almeida 2004; Bergqvist et al. 2008). Os fósseis do NEB geralmente são encontrados em tanques, depósitos sedimentares em bacias rasas com aparência de lagos, formados em fraturas ocorridas em rochas pré-cambrianas (Mabesoone et al., 1990).

Estes fósseis de mamíferos pleistocênicos são denominados como megafauna, por se tratar de um conjunto de animais, tais como mastodontes, megatérios, gliptodontes, toxodontes e dasipodídeos, que atingem massa corporal adulta acima de uma tonelada (Paula-Couto, 1979). Além destes animais, a fauna pleistocênica também era composta por mamíferos de médio e pequeno porte, tais como o tigredente-de-sabre e marsupiais, respectivamente, com distribuição por toda a América do Sul (Paula-Couto, 1953).

As descrições da fauna de mamíferos quaternários para o NEB com frequência apresentam citações de espécies ou gêneros de mamíferos, originalmente descritos para Lagoa Santa, Minas Gerais, mas também de formas consideradas endêmicas (Silva 2008; Oliveira, Porpino, e Barreto 2010; Paulo e Bertini 2015). Recentemente, contudo, foram identificados na região nordestina restos de mamíferos originalmente descritos para a América do Norte (Oliveira, Barreto, e Alves 2009). Estas recentes descobertas introduzem novas questões sobre a paleobiogeografia dos grupos que habitaram o local durante o Quaternário, com implicações paleoambientais e cronológicas importantes, ligadas ao intercâmbio interamericano. Paula-Couto (1975) aponta a presença de fósseis destes animais, datados do Pleistoceno superior, no Sudeste e NEB, como indício de uma migração ocorrida durante o UMG em decorrência da expansão dos sistemas glaciais na Cordilheira dos Andes, em decorrência da identificação, em Lagoa Santa (MG), de fósseis alóctones, tais como Ihamas e ursos, tipicamente andinos.

Por outro lado, tem havido tentativas em determinar o hábito alimentar das espécies da megafauna e, a partir deste dado, inferir o ambiente em que os animais viviam (Silva, 2008; Viana et al., 2011; Dantas et al., 2013; França et al., 2014 entre outros). Para tanto, é empregada a análise de isótopos de Carbono, Oxigênio e às 
vezes Nitrogênio, realizadas em colágeno ou bioapatita de ossos, dentes e esmalte de dentes e, desta forma, é possível determinar se os animais se alimentavam de vegetais com ciclo fotossintético $\mathrm{C} 3$ com as variações: florestas de dossel fechado $=$ variação entre $-22 \mathrm{a}-16 \%$, floresta aberta $=-16 \mathrm{a}-11 \%$, campos de ervas C3 $=-11 \mathrm{a}$ $-8 \%$, ou de gramíneas C $4=-3$ a $+5 \%$ e mistos $=-8$ a $-3 \%$ (Schoeninger e DeNiro, 1984; Cerling et al., 1999). Entretanto, são ainda escassas as iniciativas de integrar o conhecimento obtido sobre a megafauna com os dados paleovegetacionais, cronológicos e paleoecológicos (Cartelle 1999; Alves e Barreto 2007; Kinoshita et al. 2008; Silva 2008; Oliveira, Barreto, e Alves 2009).

Os restos da megafauna encontrados e descritos no NEB têm idade pleistocênica e pertencem a 35 famílias (Bergqvist e Almeida 2004). No estado de Pernambuco são descritos 12 táxons distintos, enquanto na Paraíba, Paula-Couto (1980) descreve 15 taxa distintos, e Bergqvist et al. (1997) descreve 14 e 12 táxons respectivamente. No entanto, os dois estados apresentam em comum a maior representatividade dos táxons Eremotherium, Stegomastodon e Toxodon.

O primeiro, representado por Eremotherium laurillardi (preguiça gigante) era um animal terrícola, que conseguia sustentar seu peso corpóreo em posição quase vertical e, nesta posição, chegou a atingir quatro metros de altura. Seu deslocamento se dava geralmente em grupos e seu hábito alimentar era do tipo megaherbívoros podadores que consumiam toneladas de folhas para se manter, em geral de plantas C3 (Paula-Couto, 1979; Cartelle, 2000).

Stegomastodon (mastodonte), era um animal que atingia entre $2,5 \mathrm{~m}$ a $3 \mathrm{~m}$ de altura e seu peso variava entre $4.300 \mathrm{~kg}$ e $6.100 \mathrm{Kg}$ (Christiansen, 2004). Se deslocava em bandos numerosos, próximo a bacias hidrográficas e sua manutenção dependia provavelmente da ingestão de $300 \mathrm{~kg} /$ dia de frutos, ervas, raízes, brotos de arbustos e árvores, assim como de suas cascas, em geral de plantas C3. Esses grandes herbívoros atuavam como disseminadores de sementes de árvores tropicais e palmeiras (Paula-Couto, 1979; Cartelle, 1994).

Já o Toxodon era um animal inicialmente comparado aos hipopótamos atuais e Paula-Couto (1979) e Cartelle (1994) consideram que teria hábito anfíbio, caracterizado como megaherbívoro de ambientes abertos de zonas baixas e inundadas, cuja alimentação se baseava em gramíneas, folhas e macrófitas aquáticas abrasivas. No entanto, novas investigações morfológicas têm indicado que a semelhança maior se dá com os rinocerontes atuais, que caracteriza o animal como 
terrícola (Mendonça, 2012). Apesar das discordâncias, Viana et al. (2011) determinaram com base em isótopos de carbono e oxigênio que a alimentação destes animais incluía, também, macrófitas aquáticas enquanto Oliveira, Barreto, e Alves (2009) afirmam que corpos d'água foram essenciais para a sobrevivência do gênero.

Os estudos realizados no Brasil geralmente focam na taxonomia, cronologia e rotas migratórias dos animais que compõem o registro fossilífero (Alves et al. 2007; Kinoshita et al. 2008; Silva 2008; Oliveira, Barreto, e Alves 2009; Porpino, Fernicola, e Bergqvist 2009; Oliveira, Porpino, e Barreto 2010) e outros buscam explicar a causa da extinção (Ferigolo, 1993; De Vivo e Carmignotto, 2004; Diniz-Filho, 2004)

Em relação à possível época de extinção, vários trabalhos sugerem o limite Pleistoceno/Holoceno como a data limite (Grayson 1984; Barnosky et al. 2004; Wroe et al. 2004; Koch e Barnosky 2006; Borrero 2008; Silva 2008; Rule et al. 2012; França et al. 2014). Apesar de não haver um consenso sobre a causa desta extinção, uma hipótese alternativa, proposta por Vivo e Carmignotto (2004) sugere que um clima mais úmido, na transição Pleistoceno/Holoceno, teve como resposta da vegetação, uma fisionomia mais fechada, que resultou na extinção dos megamamíferos adaptados a áreas abertas. Bergqvist e Almeida (2004), por outro lado, acreditam que as mudanças climáticas, ocorridas durante o Pleistoceno, contribuíram para a extinção dessa fauna.

Estudo baseado em modelo ecológico, com utilização de simulações computacionais, realizado por Diniz-Filho (2004) para a América do Sul, determinou que $73 \%$ da megafauna foi dizimada por atividades de caça, ao longo de aproximadamente 1.000 anos. Para a América do Norte, Alroy (2001) obteve resultado similar, ou seja, 78\%. Ferigolo (1993) por sua vez, promove a ideia de que a extinção teria ocorrido ao término do Pleistoceno por intermédio de patógenos e macroparasitas, vindos da América do Norte principalmente. Em corroboração a esta ideia, vários autores relatam que esqueletos humanos mais antigos datados na América do Sul apresentam idades radiocarbônicas entre 11.500 e 11.000 anos AP (Schmitz, 1987; Kipnis, 1998; Prous e Fogaça, 1999), o que sugere que a chegada dos primeiros grupos humanos possa ter sido responsável pela disseminação de possíveis patógenos e macroparasitas. 


\subsection{Paleoclimas}

\subsubsection{O clima do Nordeste brasileiro no Quaternário Tardio}

A região do NEB apresenta diversidade geomorfológica, geográfica, vegetacional e climática devido à sua dimensão (1.554.158 Km²), assim como sua localização - todos os 9 estados têm contato direto com o Oceano Atlântico e estão entre a linha do Equador e 15오 (Garcia, 1984).

Estas características proporcionam um range de condições climatológicas que vão do tropical sem estação seca, no litoral sul do estado da Bahia à seco, semiárido de baixa latitude e altitude, que atinge 8 dos 9 estados da região, sem no entanto ser exclusivo - a única exceção é o estado do Maranhão, que está sob duas faixas climáticas: tropical com verão seco (litoral) e tropical com inverno seco (interior) (Alvares et al., 2014).

O clima da região é diretamente influenciado pela presença da Zona de Convergência Intertropical (ZCIT), como visto no Lago do Caçó (Ledru et al., 2002; Aimola e Moura, 2016) A ZCIT apresenta padrão sazonal, alterando sua posição na zona equatorial, de acordo com a variação da temperatura da superfície oceânica, para o hemisfério que estiver com saldo energético positivo. Isto faz com que no inverno boreal a ZCIT se localize mais ao sul e no inverno austral mais ao norte. A ZCIT modula o (SMAS) Sistema de Monções do Atlântico Sul (Marengo et al., 2017), ao inserir no continente uma banda de umidade, que recebe o nome de Zona de Convergência do Atlântico Sul (ZCAS), ao ser desviada pela Cordilheira dos Andes, atingir o interior do continente e chegar à região sudeste e às vezes ao sul (Cook, 2005; Cruz et al. 2009). Uma vez que a ZCAS se desloca em direção ao sudeste, grande parte dos estados do NEB não recebem umidade durante o verão, com exceção do extremo norte, que está no limite extremo ao sul da ZCIT e os litorais, que recebem umidade proveniente das brisas marinhas. Os litorais também recebem umidade durante o inverno, com chuvas ocasionadas por Ondas de Leste (Silva, 2010).

Além da ZCIT, outros mecanismos atuam na determinação do clima no semiárido nordestino, tais como as células de Hadley e Walker e a topografia (Wanderley et al. 2019). As células de Hadley e de Walker são células de circulação de ar em altos níveis, ativadas pela diferença de pressão e atmosfera: o ar quente e leve sobe, se resfria, fica frio e pesado e desce. Associadas ao movimento de rotação da Terra, que provoca o efeito de Coriolis, são formados os ventos alísios. As células 
de Hadley, localizadas entre o equador e os trópicos, tem o movimento de ascendência na linha do equador, onde o ar é aquecido pela maior incidência solar. O ar se desloca para os trópicos, enquanto vão se resfriando e perdendo peso, devido à ocorrência da alta precipitação, comum nesta região (Aimola e Moura, 2016). O movimento de subsidência, de alta pressão, ocorre por volta dos $30^{\circ} \mathrm{S}$ e $\mathrm{N}$ e como o ar está frio e leve, sem umidade, estas regiões, geralmente, abrigam os desertos (Mendonça e Danni-Oliveira, 2007). As células de Walker apresentam circulação longitudinal, em larga escala, devido ao aquecimento diferencial entre o oceano e o continente. Se movem no sentido leste - oeste, em sintonia com a ocorrência dos eventos El Niño - La Niña (Schneider et al., 2014).

Com base no Princípio do Atualismo, supõe-se que a influência destes mecanismos tenha modelado o clima ao longo do tempo, e, em especial, nos eventos climáticos do último ciclo glacial, tais como os Heinrich e Bond. Os eventos Heinrich se referem a período de frio extremo, com aumento de geleiras no $\mathrm{HN}$, durante o período glacial, determinado pela presença de fragmentos continentais (detritos rochosos) na superfície oceânica do Atlântico Norte, carregados por extensos icebergs marinhos após se desprenderem da calota de gelo (Heinrich, 1988). Já os eventos Bond se caracterizam por diminuição de temperatura durante o Holoceno e também foram identificados em sedimentos marinhos do Atlântico Norte, que continham fragmentos de rochas continentais desprendidos pelo derretimento de icebergs (Bond et al., 1997). Momentos de alta precipitação na região dominada pelo semiárido nordestino, nestes momentos, são reconhecidos por De Oliveira, Barreto, e Suguio (1999); Arz, Pätzold, e Wefer (1998) e Nace et al. (2014), entre outros.

\subsubsection{Paleoclimas e seus indicadores}

Os paleoclimas do Quaternário nos continentes podem ser inferidos através de proxies tais como isótopos de oxigênio $\left(\delta^{18} \mathrm{O}\right)$ de espeleotemas de cavernas, grãos de pólen, diatomáceas, fitólitos e isótopos estáveis de carbono $\left(\delta^{13} \mathrm{C}\right)$ e nitrogênio $\left(\delta^{15} \mathrm{~N}\right)$ do solo.

Análises isotópicas de razão ${ }^{18} \mathrm{O} /{ }^{16} \mathrm{O}$ em espeleotemas de cavernas sugerem um aumento na umidade do Oeste Amazônico, durante o UMG, ao mesmo tempo em que o Leste passava por um período com menor umidade (Cheng et al., 2013). Estudos geoquímicos de estalagmites em cavernas do Rio Grande do Norte, por outro lado, evidenciam uma fase predominantemente seca durante o período de 26.000 a 
15.000 anos AP, com umidade entre 25.9 e 25 ka e 17.3 e 15.1 ka, fenômeno atribuído aos eventos climáticos Heinrich 2 e 1 respectivamente (Cruz et al., 2009), os quais estão em fase com dados isotópicos da Bahia (Wang et al., 2004). Esses dados paleoclimáticos corroboram a interpretação de Cartelle e Hartwig (1996) para um esqueleto completo de Protopithecus, um primata com o dobro do tamanho dos gêneros de correspondência atuais, tipicamente associado a florestas e que se extinguiu no início do Holoceno, que viveu na região do oeste da Bahia, hoje caracterizada por clima semiárido.

Análises palinológicas determinaram resfriamento estimado entre $5^{\circ} \mathrm{C}$ e $6^{\circ} \mathrm{C}$, na média anual, para o Alto Rio Negro (Colinvaux et al., 1996), setor oeste da Amazônia do Brasil, durante o período cronológico equivalente ao UMG e por Haberle (1997), para o paleodelta do Rio Amazonas. É importante ressaltar que essas conclusões têm apoio em estudos de concentração de gases raros em aquíferos do NEB por Stute et al. (1995), que estabeleceram declínio médio de temperatura em torno de $5^{\circ} \mathrm{C}$ para a Caatinga. Os estudos de De Oliveira (1992), Ledru (1992) e Ledru et al. (1996) no sudeste e os de Behling e Lichte (1997) no sul do Brasil indicam que o fenômeno climático de frentes polares estava mais intensificado durante o UMG e que, com o declínio generalizado da temperatura os ecossistemas foram rearranjados na paisagem e em locais de Cerrado houve o predomínio de Floresta de Araucária, enquanto que as áreas dessa gimnosperma no sul do Brasil foram substituídas por campos. Behling e Lichte (1997) e De Oliveira (1992), ao se basearem nos padrões biogeográficos da vegetação do Sul e do Sudeste do Brasil afirmam que nessas regiões a depressão da temperatura no UMG pode ter chegado a cerca de $12^{\circ} \mathrm{C}$. Esta afirmação vem ao encontro dos resultados obtidos por Colinvaux et al. (1996), Colinvaux e De Oliveira (2001) e Bush et al. (2002), assim como os obtidos por Pessenda et al. (2009) no sudeste, onde identificaram conjuntos polínicos que caracterizam Floresta de Araucária, típica de ambiente com clima frio e úmido em testemunho datado em 28.600 anos AP. Indicativos desta configuração também foram encontrados por Buso Jr et al. (2013) com análises isotópicas de $\sigma^{13} \mathrm{C}$, ao Norte do Espírito Santo, em sedimentos com ca. 17.000 anos, determinaram a presença de plantas com fotossíntese do tipo C3, predominante em espécies arbóreas, características de ambiente úmido. Nas proximidades do estudo desses autores, Nascimento (2012) também indica a presença de tipos polínicos amazônicos em 
sedimentos lacustres de ca. 20.000 anos AP na Lagoa Durão e por volta de 7.000 anos AP nos sedimentos da Lagoa Juparanã, Municipio de Linhares, Espírito Santo.

Com a análise de isótopos estáveis de $\mathrm{C}$ e $\mathrm{N}$, de análise granulométrica e de diatomáceas, Viana et al. (2014) determinaram a influência de eventos climáticos globais, ocorridos nos últimos 2.500 anos no norte do NEB, com alterações no nível da água de um lago, concordante com a variação da posição da ZCIT.

\subsubsection{Mudanças climáticas no NEB desde o Pleistoceno Tardio}

Análises isotópicas realizadas em ossadas de megafauna, datadas em torno de 21.000 anos AP, nos estados da Bahia, Sergipe e Alagoas identificaram a base da cadeia trófica desta fauna composta basicamente por plantas $\mathrm{C} 3$, características de clima mais úmido, enquanto no Rio Grande do Norte a dominância era de vegetação C4, indicativas de clima mais seco Dantas et al. (2013). Para esta última região, Cruz et al. (2009), obteve resultados similares, com análises de ${ }^{518} \mathrm{O}$ de espeleotemas de três cavernas, que indicaram condições secas para o UMG, intercalados com dois períodos de umidade, coincidentes com os eventos climáticos Heinrich 2 e 1 , respectivamente entre 25.900 e 25.0000 anos AP e 17.300 e 15.100 anos AP. Já os eventos de umidade determinados para a região central do NEB são apoiados por Cristalli (2006), com a identificação de florestas semi-decíduas, no estado da Bahia, características de ambientes úmidos, com idades entre 21 e 9 ka, obtidos em tufos calcáreos. Ainda na Bahia, oito depósitos descontínuos de travertino, datados com idades que variaram entre 108.000 e 9.700 anos, apresentaram intervalo entre essas datações: um deles atingiu 108.000 anos, dois obtiveram a idade em torno de 20.000 anos e os demais apresentaram idades que variaram entre 14.700 e 9.700 anos. Como os depósitos de travertino só ocorrem em situações em que há disponibilidade de água e de dióxido de carbono no solo, em níveis elevados, estas idades indicam possivelmente épocas em que a umidade predominava na região (Auler, 1999).

Similarmente, a análise de isótopos de matéria orgânica do solo em três localidades do NEB (Ceará, Piauí e Paraíba) obtiveram datações de 18.000 anos AP e demonstraram a presença de uma fase florestada entre 18.000 e 13.000 anos AP (Pessenda et al., 2010). Dados palinológicos do Rio Icatu (De Oliveira, Barreto, e Suguio 1999), na Caatinga do noroeste da Bahia, mostram a presença de táxons botânicos arbóreos de afinidades Amazônica e Atlântica, indicadores de vegetação adaptada a climas mais frios que os atuais, que indicam uma depressão de 
temperatura de pelo menos $5^{\circ} \mathrm{C}$, na média anual da região, durante a transição Pleistoceno/Holoceno. A hipótese de esfriamento dessa magnitude, na região da Caatinga, é apoiada pelos estudos sobre a composição botânica da Chapada Diamantina (Harley, 1995), que indicam a presença de uma flora típica de regiões sulinas, inserida em elevações da Caatinga baiana, tais como Podocarpus lambertii, Podocarpus sellowii, Drimys brasiliensis, Hedyosmum brasiliense, Weinmannia paulliniifolia, llex theezans e Ilex paraguariensis. Esses táxons, tipicamente associados à vegetação de clima frio, foram também encontrados anteriormente em região semiárida do Nordeste por Andrade-Lima (1966, 1982), Schultz (1985), Lorenzi (1992) e Jolly (1993), Outro apoio a esta hipótese é fornecido pelos dados paleoclimáticos obtidos a partir da análise de gases raros em paleoaquíferos do Piauí, NEB (Stute et al., 1995).

Durante o Holoceno, De Oliveira, Barreto, e Suguio (1999) demonstram para o Vale do Rio Icatu, oscilações climáticas, com tendência a progressiva aridez a partir de $8.9 \mathrm{ka}$, com pequenos episódios de umidade entre 6.2 e $4.2 \mathrm{ka}$, quando a Caatinga se estabelece na região. Estes dados estão em fase com os determinados por (Cruz et al., 2009) para a região norte do NEB (RN), onde até ca. 6 ka a condição de umidade era predominante, com o estabelecimento de clima mais seco na região se implantou a ca. 4 ka. O modelo climático Syntrace (Nace et al., 2014) demonstra a maior umidade para $\circ$ NEB, durante o Holoceno, durante o evento climático Bond 5, corresponde ao evento 8.2, com declínio da umidade até ca. $6 \mathrm{ka}$, e atinge o padrão atual por volta de $4 \mathrm{ka}$.

\subsection{Microfósseis e isótopos estáveis}

\subsubsection{Palinologia}

A Palinologia é definida como a ciência que estuda microfósseis orgânicos, chamados de palinomorfos, que são resíduos biológicos resistentes ao tratamento químico com ácido fluorídrico (HF) para a eliminação de material mineral nas amostras (Traverse, 2005). Esses microfósseis têm tamanho entre $5 \mu \mathrm{m}$ e $250 \mu \mathrm{m}$ e são encontrados em rochas sedimentares ou outros tipos de sedimentos (BarthSchatzmayr e Barros, 2011), assim como em suspensão na atmosfera, como vários tipos de grãos de pólen e esporos de plantas e fungos (Erdtman, 1986). Entre os palinomorfos, além dos grãos de pólen de angiospermas e gimnospermas, encontramse esporos de pteridófitas, briófitas e algas, restos microscópicos de animais e plantas 
e micropartículas de carvão (Salgado-Labouriau, 1973), as quais podem ser transportadas por correntes de ar, devido ao seu tamanho diminuto (Tolonen, 1986; Duffin et al., 2008).

Cada microfóssil, especialmente grãos de pólen e esporos, pertence a grupos vegetais com requerimentos ecológicos próprios, tais como quantidade de luminosidade, nutrientes, temperatura, salinidade, água e muitos outros parâmetros ambientais. Conforme estas condições se alteram, a vegetação da área atingida também sofrerá mudanças (Ricklefs, 2003). Dessa forma, o microfóssil torna-se um proxy para parâmetros definidos do meio físico, além de fornecer informações sobre os tipos de vegetação regional no passado, a sucessão da vegetação através do tempo e, de forma indireta, o paleoclima da época em que viviam as plantas que os produziram (Salgado-Labouriau, 1994).

Sob o ponto de vista arqueológico é possível distinguir, de forma indireta, influências antrópicas no meio físico, através de sinais deixados por microvestígios em sedimentos, como partículas de carvão associadas a incêndios, assim como grãos de pólen e esporos oriundos da vegetação manipulada por populações pretéritas (Salgado-Labouriau, 1973).

Até o momento somente uma análise palinológica contém o último período glacial da Caatinga, realizada por Behling et al. (2000) no testemunho marinho GeoB 3104-1, coletado na plataforma continental a $90 \mathrm{~km}$ da cidade de Fortaleza - CE. Este estudo palinológico revelou a predominância da vegetação xerófila da Caatinga, durante o intervalo de tempo entre 42.000 e 8.500 anos AP, com período de aumento de precipitação entre 15.500 e 11.800 anos AP. O Holoceno da Caatinga tem sua palinologia apresentada atualmente por dois trabalhos: O primeiro realizado no noroeste da Bahia, em sedimentos turfosos que alcançaram 10.990 anos AP em sua base, revelou a presença de táxons polínicos florestais amazônicos e atlânticos que podem ser utilizados como evidência para a existência de corredores de migração entre floras distintas (De Oliveira, Barreto, e Suguio, 1999). O segundo foi realizado na Caatinga de Pernambuco, em turfeira que atingiu 9.200 anos AP em sua base. Neste ambiente diferenciado, Medeiros et al. (2018) identificaram uma vegetação atípica na Caatinga, devido à alta umidade local, proveniente do acesso a águas subterrâneas, devido a falhas geológicas. Ainda assim, a partir de 5.700 anos AP, houve um hiato na sedimentação, que foi interpretado como consequência de diminuição da umidade local e subsequente abaixamento do lençol freático. Os 
demais registros palinológicos já realizados na região do NEB, tratam de locais fora do ecossistema Caatinga (Pessenda et al., 2005; Montade et al., 2014).

Paralelamente às análises realizadas em sedimentos, é possível a extração de palinomorfos de cálculos dentários de megafauna, que permite a recuperação de microfósseis, aderidos aos dentes dos animais, durante sua alimentação e, portanto, permite a inferência do tipo de vegetação consumidos por esses animais (Misumi et al. 2016). Adicionalmente, Sporormiella, um fungo coprólito que resiste ao processamento palinológico, tem sido utilizado em estudos relacionados à megafauna, como indicador da presença e abundância desses animais, além da época de sua extinção (Davis, 1987; Gill et al., 2009; Raczka et al., 2016). Por outro lado, micropartículas carbonizadas, também presentes em lâminas palinológicas, são geralmente utilizadas para determinação de atividades humanas, inferidas através de sinais de paleoincêndios (Scott e Damblon 2010; Raczka, Bush, e De Oliveira 2018) .

\subsubsection{Diatomáceas}

Diatomáceas são algas unicelulares ou coloniais, cuja parede celular é composta por sílica. São encontradas tanto em ambiente marinho como dulcícola e seu número de espécies gira em torno de 100.000. Suas paredes são divididas em duas partes, chamadas de frústulas, as quais apresentam uma grande diversidade de ornamentações, formadas por canais, depressões ou poros e outras estruturas, que possibilitam a identificação a nível de espécie (Raven et al., 2001).

As algas diatomáceas têm importante aplicação como bioindicadores de condições ecológicas, em ecossistemas aquáticos presentes ou passados, em termos de acidez, temperatura, salinidade, oxigênio dissolvido, transparência, níveis tróficos, entre outros, através da determinação sistemática dos táxons encontrados (Patrick e Reimer, 1966; Round et al., 1990; Battarbee et al., 2001). Também têm grande importância em estudos paleoambientais na determinação de paleoníveis da coluna d'água através de determinação da abundância de diatomáceas planctônicas (indicadoras de coluna d'água mais profundas) x diatomáceas perifíticas (indicadoras de lagos rasos e pântanos), que proliferam preferencialmente em pântanos e sistemas aquáticos rasos (Battarbee et al., 2001).

No NEB, diatomáceas como bioindicadores foram utilizadas por Suguio et al. (2013) em análise de sedimentos da Lagoa Olhos D’Água, em Recife - PE, para determinação de variação do nível do mar; e para inferir ativação de dunas 
relacionadas a paleoclimas do Holoceno, na Lagoa Boqueirão em Touros - RN (Viana et al., 2014; Utida, 2016).

\subsubsection{Fitólitos}

Fitólitos são micropartículas de sílica opaca depositadas em tecidos e células vegetais, resultantes de processos biológicos e físicos. A planta absorve ácido monossilícico $\left(\mathrm{H}_{4} \mathrm{SiO}_{4}\right)$ dissolvido em água presente no solo, o qual é polimerizado várias vezes e finalmente cristalizado como dióxido de sílica $\left(\mathrm{SiO}_{2}\right)$ em moldes presentes nas células das folhas, caules, raízes e estruturas reprodutivas (Piperno, 2006; Mazumdar, 2011; Watling e Iriarte, 2013; Lorente et al., 2015). São produzidos pelos vegetais para obtenção de maior resistência a herbívoros e fungos patogênicos, proteção contra toxidade de metais pesados e contra dissecação, entre outros fatores (Piperno, 2006; Mazumdar, 2011).

São produzidos com formas e ornamentações variadas e com tamanhos que variam de 2 a $200 \mu \mathrm{m}$, que possibilitam a identificação do grupo vegetal ao qual pertencem e alguns poucos são considerados diagnósticos, pois permitem a identificação taxonômica mais apurada, a nível de gênero (Runge, 1999). No entanto, plantas da mesma espécie podem produzir quantidades de fitólitos diferentes, uma vez que sua produção depende da disponibilidade de sílica e água no solo, do clima e idade da planta (Dickau et al., 2013). Podem ser encontrados em sedimentos terrestres e lacustres e por serem inorgânicos são facilmente preservados, inclusive em meios oxidantes, onde grãos de pólen se degradam. São ainda considerados os microfósseis vegetais mais duráveis, uma vez que sua degradação se dá somente em soluções básicas (Mulholland, 1989; Runge, 1999; Piperno, 2006; Dickau et al., 2013). São produzidos por monocotiledôneas, dicotiledôneas, gimnospermas e pteridófitas (Bozarth, 1992; Iriarte e Paz, 2009; Mazumdar, 2011; Watling e Iriarte, 2013; Dickau et al., 2013; Kumari e Kumarasamy, 2014).

Por esses motivos, são excelentes proxies para estudos da dinâmica florestal, de reconstrução paleovegetacional e paleoambiental e arqueológicos (Runge, 1999; Mercader et al., 2011; Watling e Iriarte, 2013; Dickau et al., 2013; Lorente et al., 2015; Maezumi et al., 2015; Carson et al., 2016). Entretanto, a análise de fitólitos apresenta algumas desvantagens: algumas famílias não produzem fitólitos; a ocorrência de multiplicidade, onde um determinado táxon produz vários morfotipos diferentes de 
fitólitos; e a redundância, que ocorre quando vários táxons produzem o mesmo padrão morfológico (Barboni e Bremond, 2009).

\subsubsection{Isótopos de $\mathrm{C}$ e $\mathrm{N}$}

A fotossíntese é a forma pela qual a energia proveniente do Sol entra na biosfera, com assimilação de dióxido de carbono $\left(\mathrm{CO}_{2}\right)$ da atmosfera em consequente produção de compostos orgânicos. Neste processo o carbono pode ser incorporado pelos organismos fotossintetizantes de duas formas diferentes: a primeira, denominada de Fotossíntese $\mathrm{C} 4$, mais eficaz, característica de plantas chamadas $\mathrm{C} 4$, adaptadas a maior luminosidade, maior temperatura e estresse hídrico; e a menos eficaz, a Fotossíntese C3, embora mais prevalente na Natureza, é encontrada em plantas adaptadas a ambientes mais úmidos (Raven et al., 2001). Por consequência, plantas com fotossíntese C3 são predominantes em florestas tropicais enquanto que as C4 são mais comuns em vegetação tropical aberta (Pessenda et al., 2010a).

$\mathrm{Na}$ atmosfera são encontrados dois isótopos estáveis de carbono, $0{ }^{13} \mathrm{C}$ e $\mathrm{o}$ ${ }^{12} \mathrm{C}$, em uma proporção de $1,11 \%$ para $98,89 \%$, respectivamente (Boutton, 1996). Amostras ambientais analisadas através da determinação da composição isotópica determinam o ciclo fotossintético utilizado pelas plantas ali depositadas, uma vez que prevalece a discriminação contra $0{ }^{13} \mathrm{CO}_{2}$ durante a fotossíntese (Vogel, 1980; O'Leary, 1988; Farquhar et al., 1989). Plantas com ciclo fotossintético $C_{3}$ (árvores e gramíneas aquáticas e bambusóides) possuem composição isotópica de carbono ( $\delta$ ${ }^{13} \mathrm{C}$ ou ${ }^{13} \mathrm{C} /{ }^{12} \mathrm{C}$ ) entre $-22,0 \%$ e $-32,0 \%$, com média de $-27,0 \%$, enquanto nas com ciclo fotossintético $\mathrm{C} 4$ o $\delta{ }^{13} \mathrm{C}$ varia entre $-9,0 \%$ e -17,0\%, com média de $-13,0 \%$ (Boutton, 1991, 1996; Pessenda et al., 2005).

Na região da Caatinga do NEB, foram realizadas análises isotópicas em um transecto de $200 \mathrm{~km}$ no estado de Pernambuco, a partir do litoral até o Vale do Catimbau (Ribeiro 2002) e um outro transecto através dos estados de Ceará, Piauí e Paraíba (Pessenda et al., 2010a), ambos os trabalhos, com o objetivo de determinar o paleoambiente e o paleoclima para a região, indicaram condições ambientais de floresta entre ca. 18.000 e 13.000 anos AP.

Os isótopos estáveis do nitrogênio $\left({ }^{14} \mathrm{~N}\right.$ e $\left.{ }^{15} \mathrm{~N}\right)$ também são utilizados em estudos ambientais, mas com uma diferença básica. As plantas vasculares possuem pequena quantidade de nitrogênio, enquanto em plantas não vasculares, como as do fitoplâncton a quantidade é considerável (Talbot e Johannessen, 1992). A variação 
entre as fontes de nitrogênio no ambiente é preservada nos valores de $\delta{ }^{15} \mathrm{~N}$, com $+8,5 \%$ na matéria orgânica com algas e $+0,5 \%$ com plantas terrestres. Portanto, a análise de $\delta{ }^{15} \mathrm{~N}$ é fundamental para a determinação de matéria orgânica de origem aquática ou terrestre (Peterson e Howarth, 1987). 


\section{LOCAIS DE ESTUDO}

Devido à correlação proposta pelo presente projeto, entre dados palinológicos e paleontológicos, há a necessidade de coleta de sedimentos em depósitos lacustres e/ou cacimbas com restos de megafauna. Os pontos de coleta deste trabalho, localizados entre os estados de Pernambuco e Paraíba, estão distribuídos em latitudes, longitudes e altitudes variadas e esta variação influencia diretamente a distribuição de umidade e consequentemente a vegetação local, tanto nos dias atuais como no passado. A figura 1 apresenta os pontos onde foram realizadas as coletas em cacimbas e lagos efêmeros, assim como a distribuição da vegetação, a figura 2 apresenta o relevo da região estudada e a figura 3 a variação de precipitação ao longo do ano.

Para facilitar a leitura, a caracterização dos locais de coleta das amostras, os trabalhos de campo e os respectivos resultados são descritos em capítulos independentes, correspondentes a cada localidade estudada. Em seguida serão apresentadas a discussão geral e as conclusões do trabalho. 


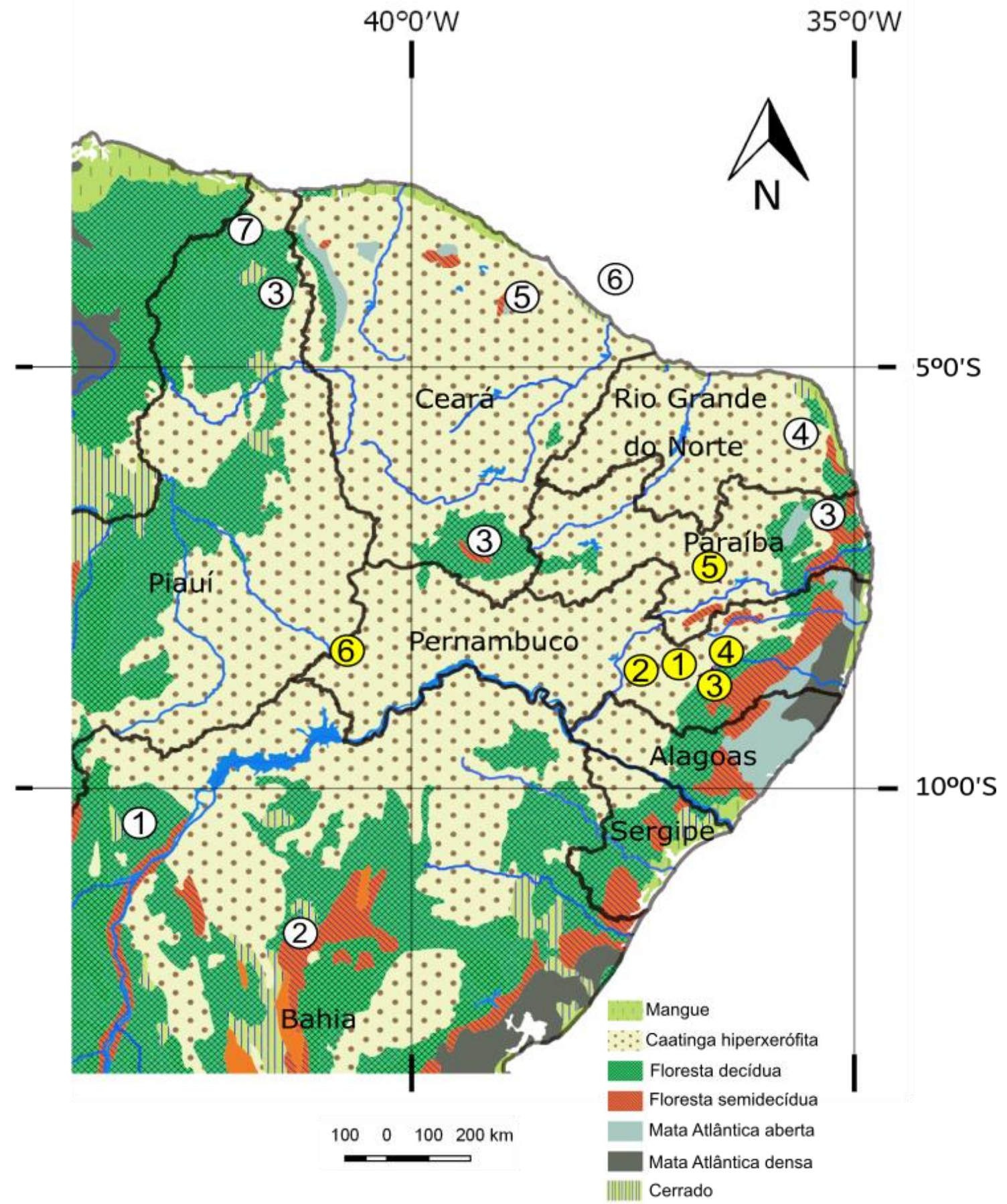

Figura 1. Mapa de localização dos pontos de estudo, em relação a estudos paleoclimáticos anteriormente realizados, mostrando a distribuição da vegetação do NEB, elaborado em Q GIS 2.18 Las Palmas software. Círculos amarelos - locais estudados: 1 - Vale do Catimbau, Buíque (PE); 2 Ibimirim (PE); 3 - Capoeiras (PE); 4 - São Bento do Una (PE); 5 - São João do Cariri (PB); 6 -Afrânio (PE). Círculos brancos - estudos referenciados: 1 - Rio Icatu (De Oliveira et al., 1999); 2 - Cavernas Diva de Maura e Torrinha (Novello et al., 2014); 3 - PARNA, FLONA e REBIO (Pessenda et al., 2010); 4 - Rio Grande do Norte (Cruz et al., 2009); 5 - Serra do Maranguape (Montade et al., 2014); 6 - GeoB 3104-1 (Behling et al., 2010); 7 - Rio Parnaíba (Mendes, 2016). 


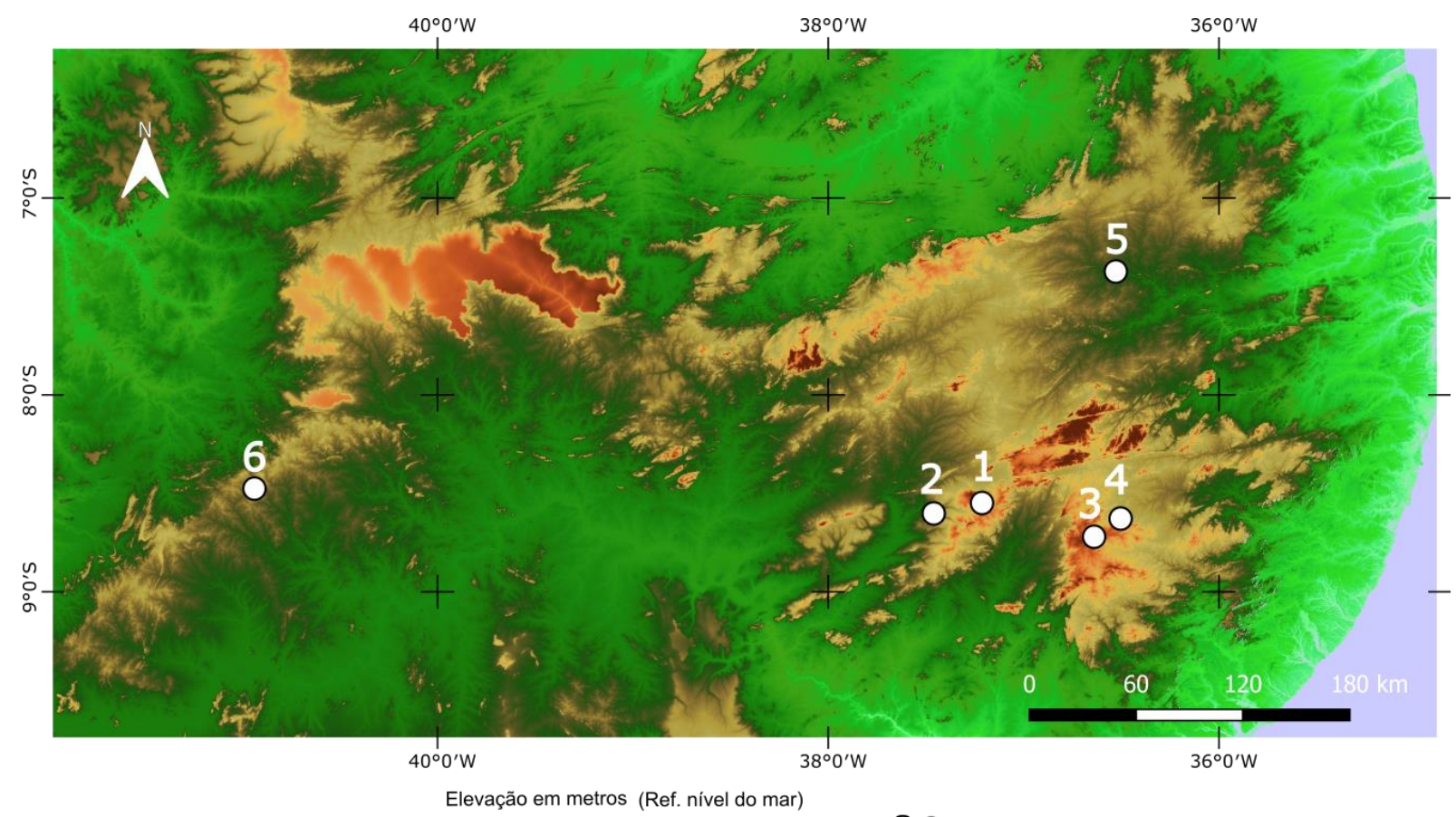

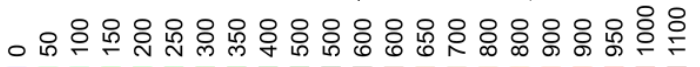

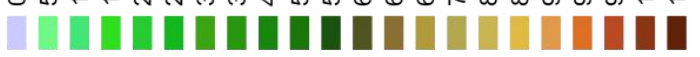

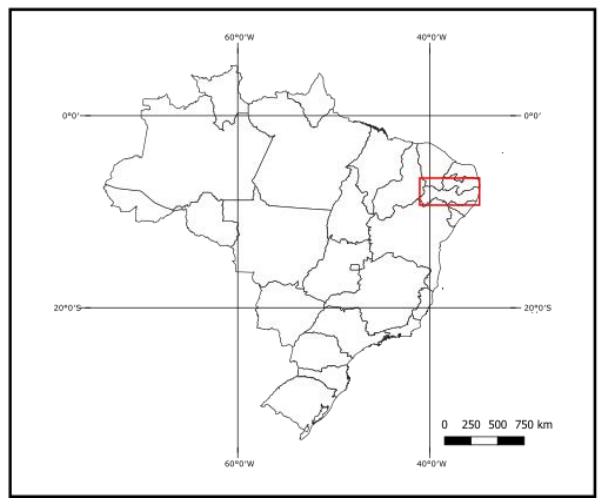

o áreas de estudo

1- Vale do Catimbau

2-Ibimirim

3-Capoeiras

4-São Bento do Una

5-São João do Cariri

6-Afrânio

Figura 2. Mapa geral de relevo da região estudada, com os pontos de coleta de sedimentos. 

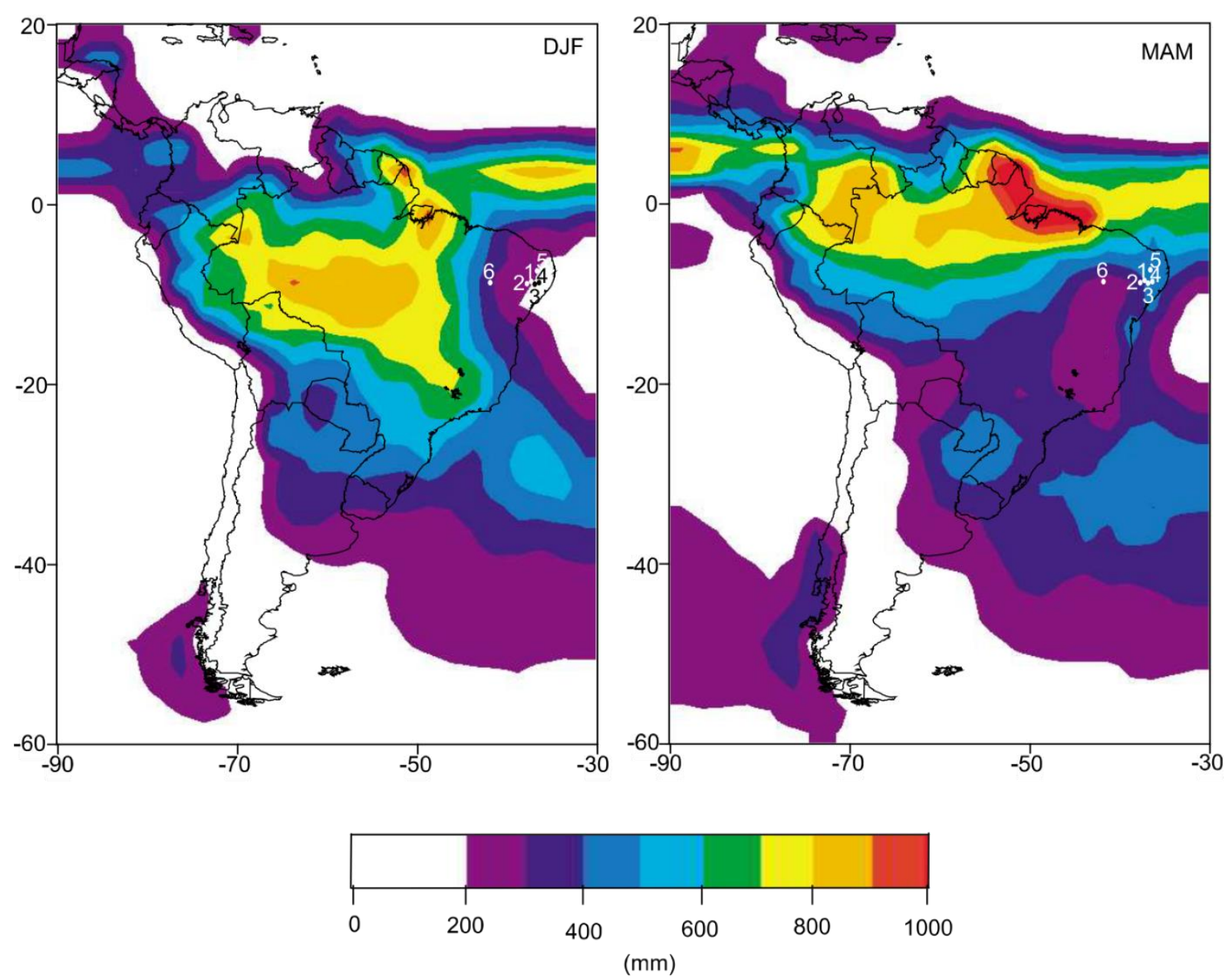

Figura 3. Distribuição média de precipitação sazonal (em $\mathrm{mm}$ ). Entre dezembro e fevereiro à esquerda e entre março e maio à direita. Os números se referem aos locais de estudo. Modificado de (Cruz et al., 2009). 


\section{MATERIAL E MÉTODOS}

\subsection{Trabalhos de campo}

Os trabalhos de campo foram realizados em etapas distintas: Fevereiro de 2014 - Vale do Catimbau - PE; Setembro de 2015 - Ibimirim e São Bento do Una - PE; Outubro de 2015 - Capoeiras - PE; Março de 2016 - São João do Cariri - PB; Setembro de 2017 - Afrânio - PE.

Além das coletas realizadas, foram feitas prospecções para localização de sedimentos orgânicos, tanto no estado de Pernambuco, quanto da Paraíba, concomitante com os trabalhos de coleta de sedimento ou não, como segue:

- Fevereiro de 2014: Prospecção em Ibimirim - PE ( Figura 4).

- Junho de 2014: Prospecção em São Bento do Una - PE (Figura 5).

- Setembro de 2015: Prospecção em cacimba localizada no município de Capoeiras - PE (Figura 6) e em localidades dos municípios de Cabaceiras e Boa Vista - PB (Figura 7).

- Março de 2016: Prospecção em Cabaceiras e Monteiro - PB (Figura 8 ) e Afrânio - PE (Figura 9).

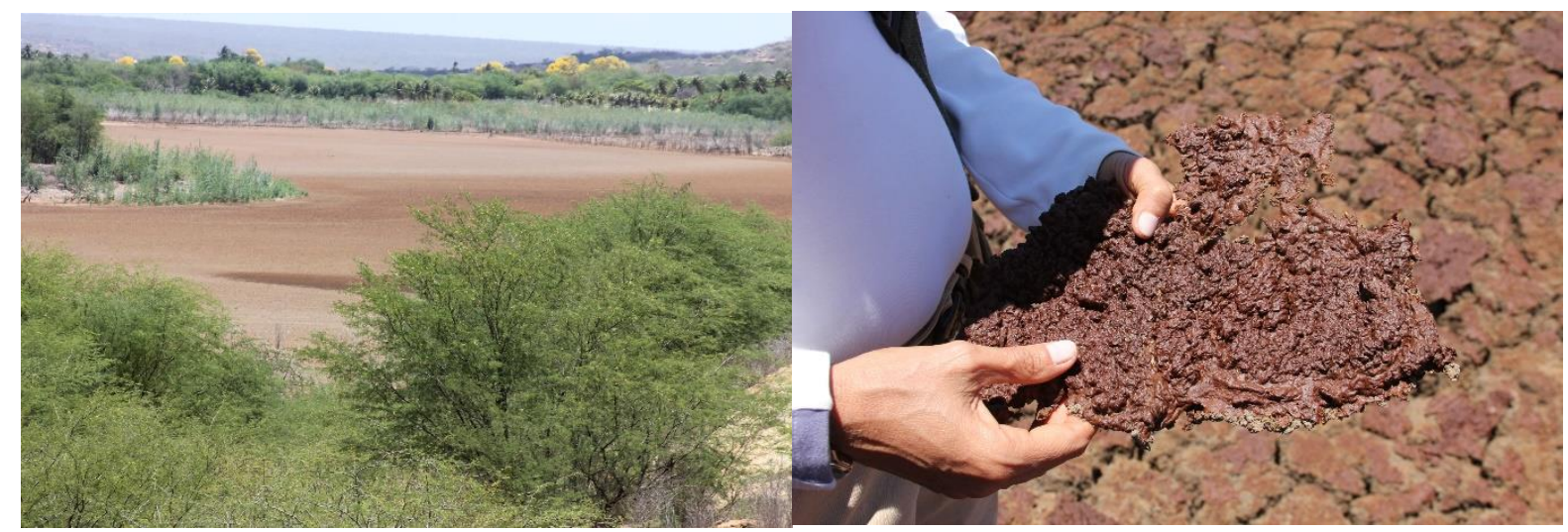

Figura 4. Imagem da prospecção em lagoa seca, no município de Ibimirim - PE, quando foi avaliada a textura dos sedimentos, em fevereiro de 2014. Fotos: Paulo E. de Oliveira.

Durante as prospecções foram averiguados os tipos de sedimentos, se eram orgânicos e se haviam sido alterados, qual a técnica a ser empregada para a coleta e a viabilidade da coleta em termos de distância a ser percorrida com o equipamento a ser utilizado. No caso de Cabaceiras, durante a prospecção realizada em março de 2016, os sedimentos foram escavados e foram coletadas amostras, as quais se 
revelaram inférteis para palinologia. Os sedimentos encontrados sobre os lajedos se mostraram inviáveis, pela logística para transporte do amostrador Vibro-Core ou mesmo Livingstone (Colinvaux et al., 1999). Em Afrânio, também em março de 2016, foi realizada a tentativa de coleta dos sedimentos com o amostrador Livingstone, no entanto, a superfície dos sedimentos lacustres, sob 1,80 m de água, se revelaram impenetráveis ao equipamento.

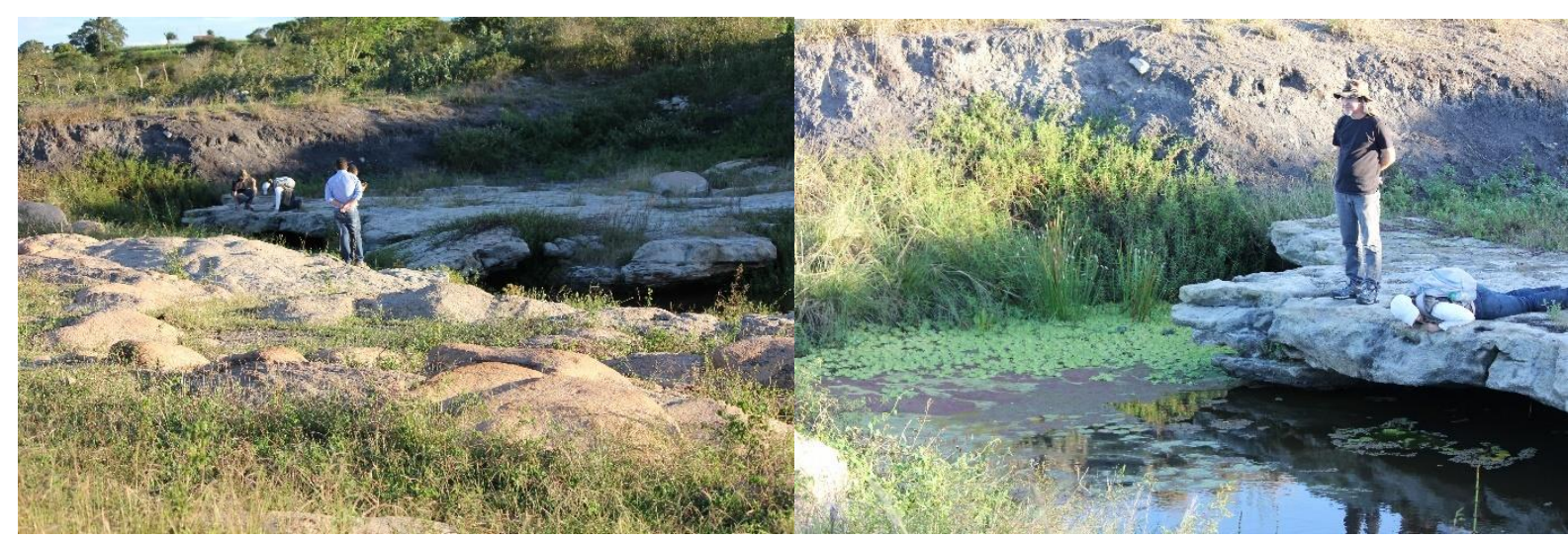

Figura 5. Imagens das prospecções em cacimba localizada no município de São Bento do Una, em junho de 2014. Foto: Paulo E. de Oliveira.

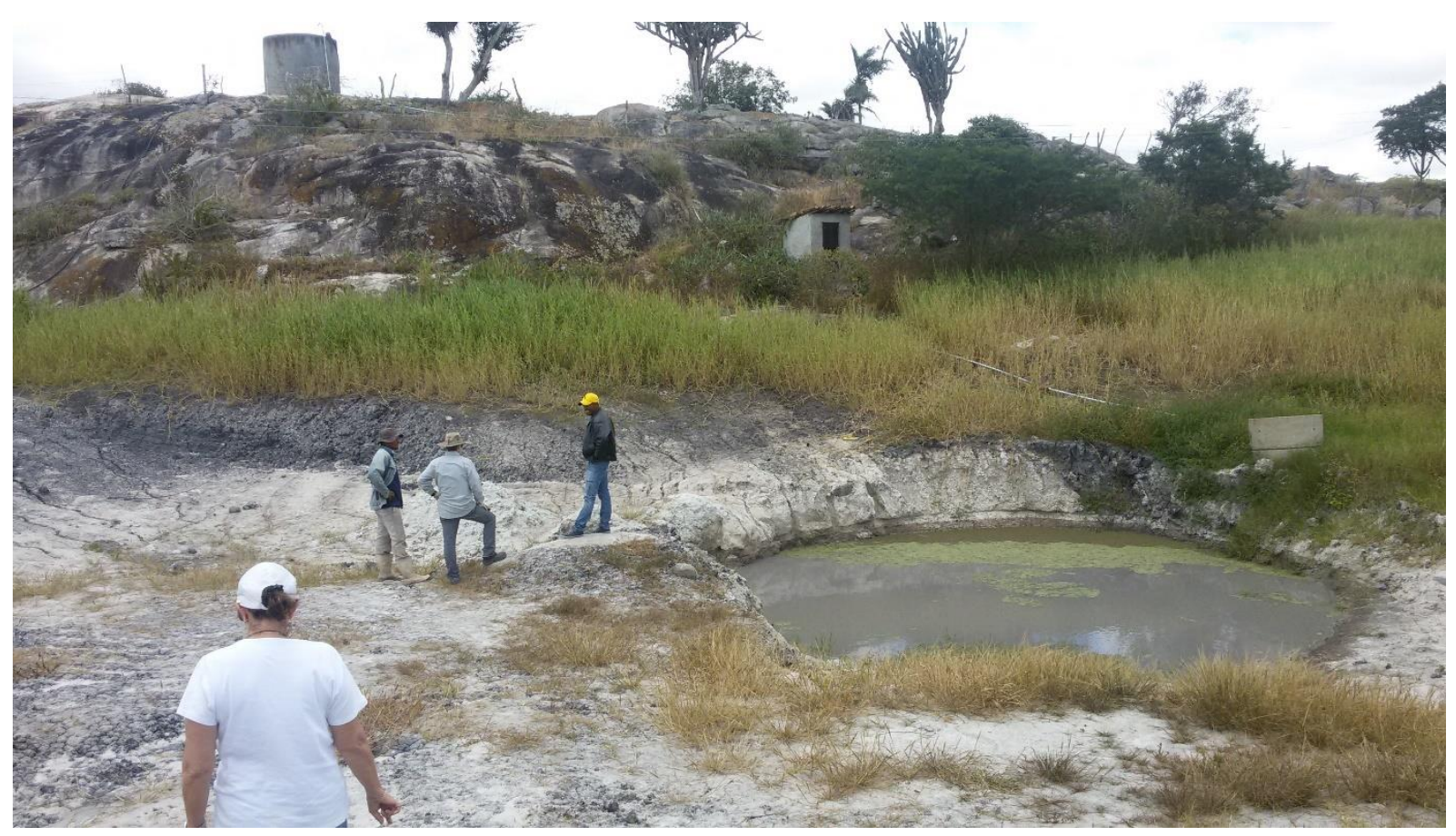

Figura 6. Imagem de prospecção em cacimba localizada no município de Capoeiras - PE, em setembro de 2015. Foto: Vanda Medeiros 

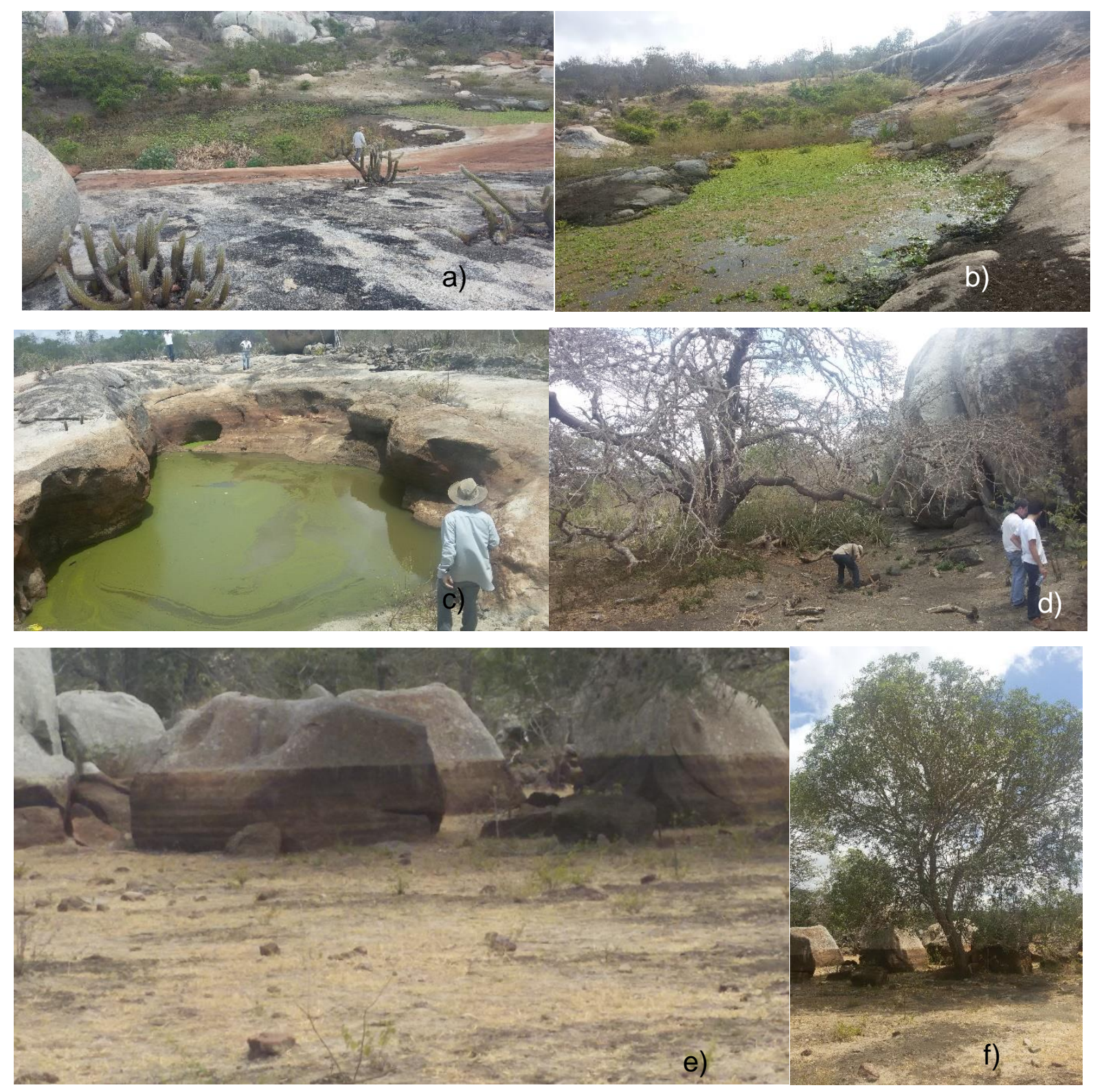

Figura 7. Imagens de prospecções realizadas nos municípios de Cabaceiras e Boa Vista - PB, em setembro de 2015. a, b, c) Sobre lajedos; d, e, f) em lagoas secas. Fotos: Vanda Medeiros.

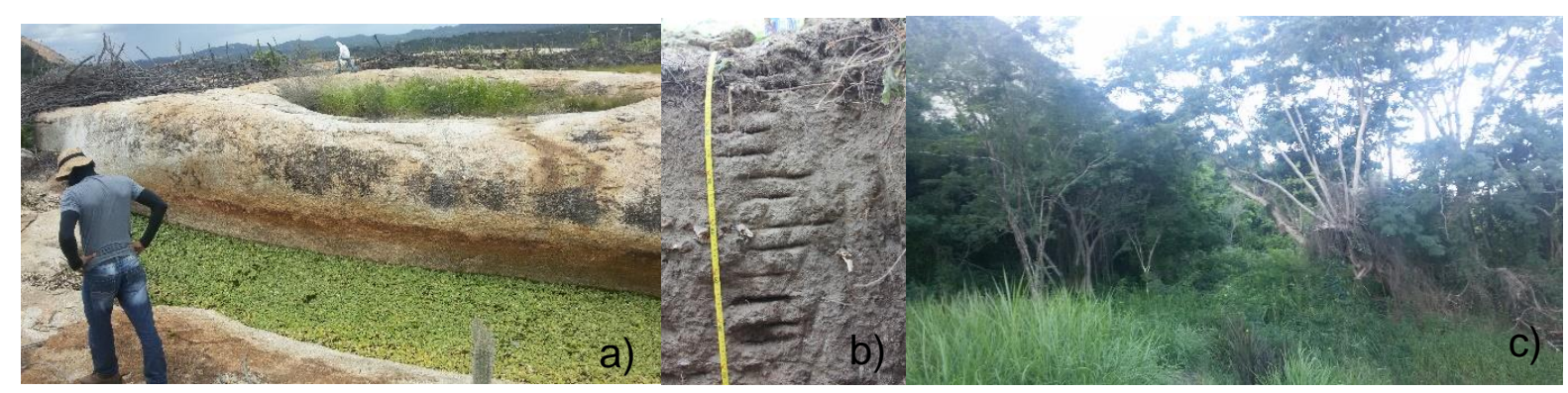

Figura 8. Imagens de prospecções realizadas no estado da Paraíba em março de 2016. a) sobre o Lajedo da Gangorra no município de Cabaceiras - PB; b) em região de ecótono Caatinga/Mata Atlântica em Cabaceiras - PB; c) em brejo de altitude no município de Monteiro - PB. Fotos: Vanda Medeiros 


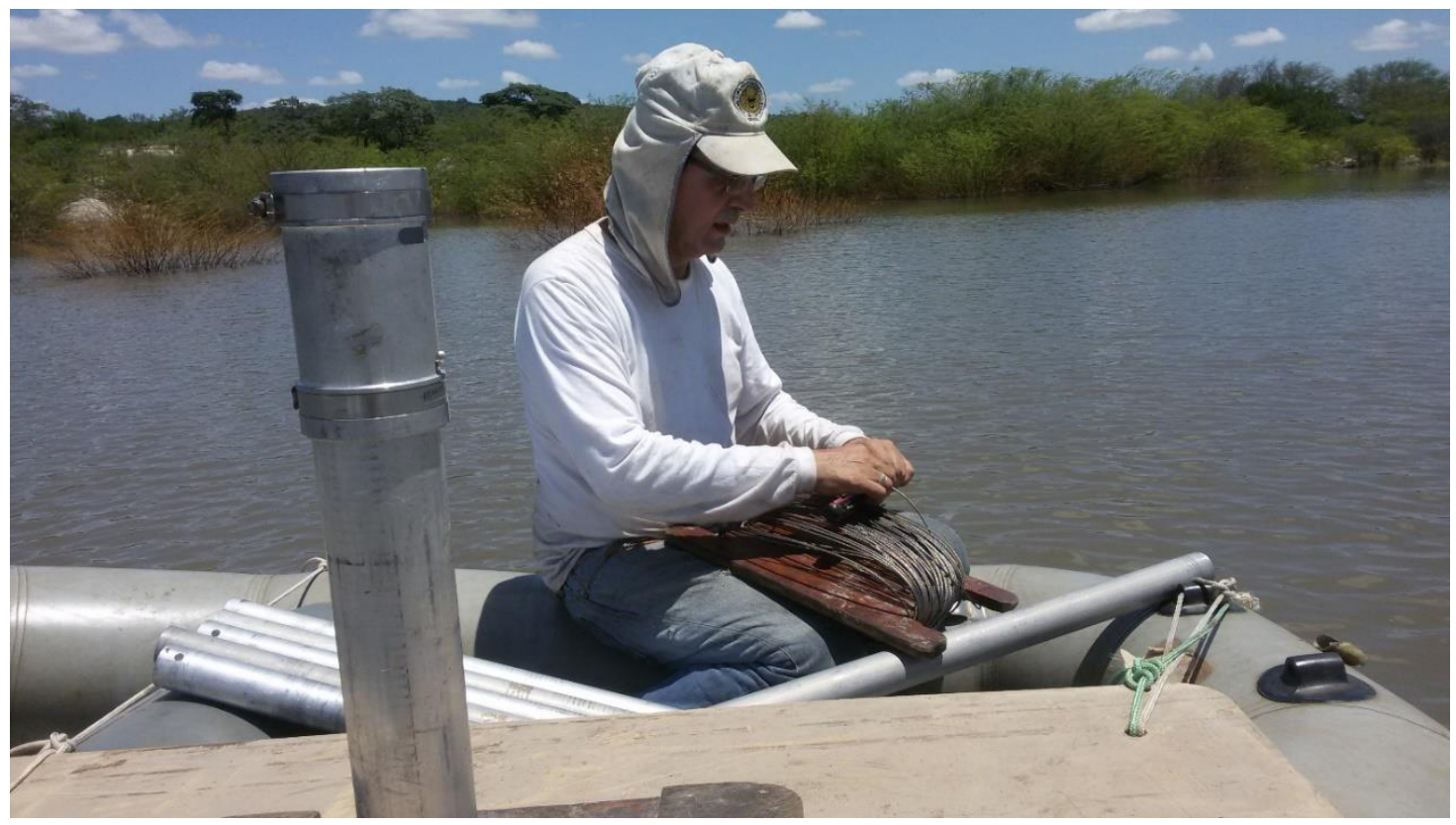

Figura 9. Tentativa de coleta de sedimentos com o amostrador Livingstone em lagoa localizada no município de Afrânio - PE, em março de 2016.

\subsection{Trabalhos de laboratório}

Os testemunhos coletados em tubos foram descritos quanto à litologia, coloração e textura, fotografados e amostrados para análises microfossilíferas, isotópicas e datação AMS (Espectometria de Massa com Acelerador), no laboratório de Micropaleontologia do IGc-USP como mostra a figura 10. Parte das amostras de sedimentos orgânicos, para datação, foram enviadas aos laboratórios da Beta Analytic Inc., Miami, EUA.
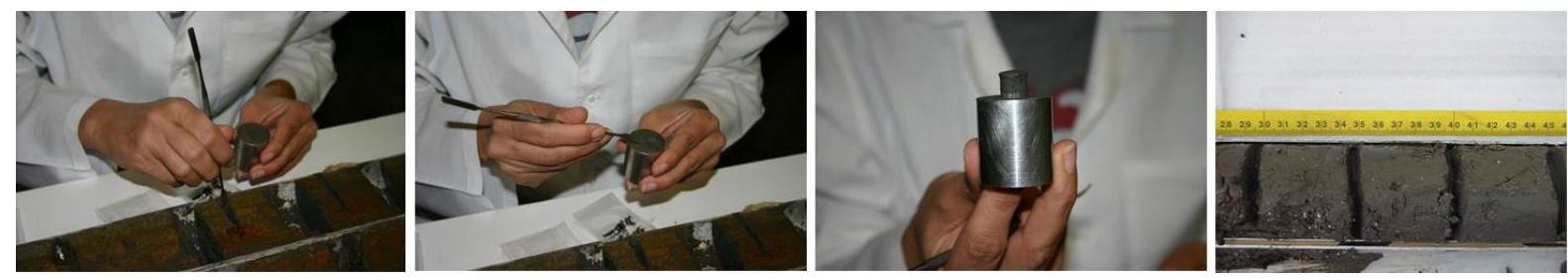

Figura 10. Subamostragem de testemunho em amostras de $1 \mathrm{~cm}^{3}$. Fotos: Vanda Medeiros

\subsubsection{Protocolos micropaleontológicos}

a) Palinologia

As amostras de sedimentos para a análise palinológica foram tratadas de acordo com a técnica descrita em Colinvaux et al. (1999), onde amostras, que variaram entre 1 a $3 \mathrm{~cm}^{3}$, de acordo com o tipo de sedimento, foram colocadas em 
tubos de centrífuga de polipropileno de $15 \mathrm{ml} \mathrm{e}$, em seguida, submetidas às etapas do protocolo palinológico que consiste em: adição de 1-2 pílulas do marcador exótico Lycopodium clavatum (Stockmarr, 1971); remoção de carbonato com $\mathrm{HCl}$ (ácido clorídrico) 10\%; dissolução de silicatos com HF (ácido fluorídrico) 40\%; eliminação de ácido húmico por solução de $\mathrm{KOH}$ (hidróxido de potássio) $5 \%$, por 5 minutos a quente; uma lavagem com ácido acético glacial concentrado para eliminação da água; reação de acetólise ( 9 partes de anidrido acético : 1 parte de ácido sulfúrico concentrado), em banho-maria por 10 minutos; interrupção da reação com ácido acético glacial concentrado, seguida de lavagem com água destilada e álcool absoluto e, finalmente, dispersão do resíduo final em glicerina. Amostras cuja quantidade de sedimentos finos era muito grande, ou que tinha muita matéria orgânica amorfa, foram submetidas ao processo de tamisação, que consiste no peneiramento em malha de $5 \mu \mathrm{m}$, simultâneo ou não com banho em ultrassom, antes da lavagem com álcool. Posteriormente as amostras foram colocadas em estufa por $8 \mathrm{~h}$ a $45^{\circ} \mathrm{C}$ para a evaporação total do álcool. Para a montagem das lâminas foi utilizado uma gota de glicerina com o resíduo final sobre lâmina microscópica. Esta foi recoberta por lamínula, cujas bordas foram preenchidas com parafina líquida quente.

Os trabalhos de identificação, descrição e contagem dos grãos de pólen e demais palinomorfos foram feitos em microscópio óptico com sistema de captura de imagens digitalizadas. As análises foram feitas sob aumento de $630 \mathrm{X}$ e 1000X (imersão em óleo). Para a identificação dos tipos polínicos foi utilizada a coleção palinológica de referência do Laboratório de Micropaleontologia do Instituto de Geociências da Universidade de São Paulo (IGc/USP), que contém mais de 7000 táxons neotropicais. Também foram realizadas consultas à literatura especializada (Salgado-Labouriau, 1973; Roubik e Moreno Patiño, 1991; De Oliveira, 1992; Colinvaux et al., 1999; Hilder, 2007; Oliveira e Santos, 2014; Silva et al., 2016; Lorente et al., 2017; entre outros). Em relação à contagem, foram contados os grãos de pólen, esporos de pteridófitas e briófitas, zigósporos de algas, grãos de pólen quebrados, corroídos e amassados e micropartículas carbonizadas, as quais foram separadas em duas categorias (menores e maiores que $100 \mu \mathrm{m}$ ). Inicialmente foi estipulada a obtenção de 200 grãos de pólen ou 300 palinomorfos, não incluídos os grãos alterados e as micropartículas de carvão, assim como as glochidias de Azolla.

Os dados obtidos foram tratados estatisticamente através dos programas específicos TILIA, TILIAGRAPH e CONISS (Grimm, 1987; Grimm e Troostheide, 
1994). O programa Tilia processa os dados brutos da contagem polínica e calcula as porcentagens e concentrações de cada táxon encontrado, enquanto o programa TILIAGRAPH produz os diagramas polínicos e o programa CONISS permite uma análise estatística preliminar dos dados para a geração de um dendrograma, a fim de se estabelecer as zonas do perfil palinológico a partir de similaridade entre as amostras em uma sequência sedimentar. Para o cálculo de porcentagem, foi realizada a soma polínica sem os demais palinomorfos (algas, pteridófitas e micropartículas carbonizadas) e sem os grãos danificados, amassados e corroídos, que não puderam ser identificados. Palinomorfos representativos estão ilustrados no Anexo 1.

\section{b) Diatomáceas}

A metodologia aplicada para o estudo diatomológico seguiu o padrão descrito por Battarbee (1986). Cerca de $1 \mathrm{~cm}^{3}$ de amostra foi oxidado com água oxigenada $\left(\mathrm{H}_{2} \mathrm{O}_{2}\right)$ a 30 volumes e, posteriormente lavado com água deionizada, no mínimo três vezes, até a normalização do $\mathrm{pH}$. Com o resíduo, foram montadas lâminas permanentes em resina Entellan, que foram submetidas à análise sob microscópio óptico biológico, sob aumento de 1000X, em imersão a óleo. A identificação dos táxons foi feita com base em comparações com táxons neotropicais existentes na literatura (Patrick e Reimer, 1966, 1975; Bicudo e Bicudo, 1970; Round et al., 1990; Moro e Fürstenberger, 1997; Fürstenberger, 2001). Os táxons identificados e descritos quanto à sua morfologia foram quantificados e tratados estatisticamente pelos programas TILIA e TILIA GRAPH (GRIMM; TROOSTHEIDE, 1994), assim como a zonação do perfil de diatomáceas foi realizado pelo programa CONISS (GRIMM,1987). A contagem das frústulas de diatomáceas seguiu o padrão recomendado no protocolo acima descrito, no qual se específica 500 frústulas por amostra.

c) Fitólitos

A metodologia para extração de fitólitos seguiu o descrito em Lombardo et al. (2016). Dispersão de argilas com hexametafosfato de sódio, por 15 minutos no ultrassom a quente $\left(60^{\circ} \mathrm{C}\right)$, remoção de carbonatos com $\mathrm{HCl} 10 \%$, peneiramento para criar duas sub-amostras (<53 $\mu \mathrm{m}$ e $53-250 \mu \mathrm{m}$ ), remoção de orgânicos com peróxido de hidrogênio, em aparelho de ultrassom a $60^{\circ} \mathrm{C}$ e ciclos alternados de $30 \mathrm{~min}$ com e sem agitação, remoção de argilas com hexametafosfato, no ultrassom quente por 15 
min, flotação com cloreto de zinco. As lâminas foram montadas em resina Entellan. A contagem foi realizada sob microscopia ótica, sob aumento de 400X. A fração grossa foi contada em sua totalidade em uma lâmina e a fração fina foi contada até a obtenção de 200 fitólitos.

d) Análise micropaleontológica em cálculos dentários

No Laboratório de Paleontologia, do Departamento de Geologia da Universidade Federal de Pernambuco (UFPE), foram coletados cálculos dentários de molares de Stegomastodon waringi, espécie da Família Gomphotheriidae, para a extração de grãos de pólen, esporos e fitólitos, através de técnica descrita em Misumi et al. (2016). Os cálculos dentários foram extraídos de cinco amostras de fragmentos e/ou molares, pertencentes à megafauna pleistocênica do NEB, sendo que um dos molares foi coletado no campo realizado em Outubro/Novembro de 2015, na Fazenda Currais Queimados em Capoeiras - PE, e os outros quatro pertencem à coleção científica da UFPE.

O molar coletado no município de Capoeiras - PE foi lavado com água deionizada, para a remoção dos detritos, ainda agregados a ele, do depósito no qual estava localizado. Os resíduos, compostos por água e por sedimentos aderidos ao dente, foram coletados e peneirados com malha de $250 \mu \mathrm{m}$ para descarte de areia grossa e em seguida com peneira de $10 \mu \mathrm{m}$, para coleta de microfósseis. Em seguida foi realizada a limpeza dos molares com acetona e etanol P.A e posterior remoção dos cálculos, com equipamentos odontológicos. O processamento químico das amostras para extração de microfósseis dos cálculos dentários foi realizado no Laboratório de Micropaleontologia do IGc/USP e consistiu em maceração do cálculo, adição de marcador exótico (Lycopodium clavatum), ácido clorídrico 37\%, lavagens com água deionizada e passagem pelo ultrassom. A montagem das lâminas foi feita em glicerina. Após a análise inicial das lâminas montadas, foi percebido que não era possível a observação e identificação confiável dos grãos de pólen. Por este motivo a glicerina presente nos resíduos foi retirada com lavagem em álcool P.A. e o material foi submetido ao processo de acetólise, ou seja, reação com mistura de 9 partes de anidrido acético para uma de ácido sulfúrico, para a remoção da matéria orgânica (Colinvaux et al., 1999). Após esta etapa, os resíduos foram novamente lavados em água e em álcool P.A., para a montagem de lâminas e posterior análise. A análise dos 
microfósseis foi realizada sob aumento de $630 \mathrm{X}$ e 1000X e foram contados todos os elementos encontrados em uma lâmina.

\subsubsection{Análises isotópicas e elementares de carbono e nitrogênio}

Amostras de $2 \mathrm{~cm}^{3}$, dos testemunhos de Capoeiras (PE), São Bento do Una $(P E)$ e São João do Cariri (PB), conforme tabela 1, foram enviadas ao Laboratório de Isótopos Estáveis - CENA/USP, para a determinação de razões ${ }^{13} \mathrm{C} /{ }^{12} \mathrm{C}$ em espectrômetro de massas ANCA GSL 20-20, da Europa Scientific, com analisador elementar acoplado. Foram também a concentração de carbono orgânico total (COT) e nitrogênio total (NT).

Após as análises, os resultados de COT e NT foram expressos em porcentagem, em relação ao peso de massa seca da amostra, com precisão de 0,1 \% para COT e $0,2 \%$ para NT. Já as razões isotópicas foram reportadas em unidades " $\delta$ ", determinadas em relação aos padrões internacionais PDB, para ${ }^{13} \mathrm{C}$ (Pessenda et al., 2010b). 
Tabela 1. Relação de amostras encaminhadas para análises de carbono e nitrogênio, com a descrição dos sedimentos correlatos

\begin{tabular}{|c|c|c|c|}
\hline Local & Código (Amostra) & Profundidade $(\mathrm{cm})$ & Tipo de sedimento \\
\hline \multirow{11}{*}{ Capoeiras (PE) } & Cap1-0 & 0 & \multirow{8}{*}{$\begin{array}{c}\text { Areia grossa } \\
\text { Areia com cascalho }\end{array}$} \\
\hline & Cap1-40 & 40 & \\
\hline & Cap1- 80 & 80 & \\
\hline & Cap1-120 & 120 & \\
\hline & Cap2 - 25 & 145 & \\
\hline & Cap3 - 9 a 12 & 154 a 157 & \\
\hline & Cap3 - 23 a 27 & 168 a 172 & \\
\hline & Cap3 - 40 a 45 & 185 a 190 & \\
\hline & Cap4 - 0 & 202 & \multirow[t]{3}{*}{ Areia siltosa } \\
\hline & Cap4-20 & 222 & \\
\hline & Cap4-40 & 242 & \\
\hline \multirow{11}{*}{$\begin{array}{l}\text { São Bento do Una } \\
\text { (PE) }\end{array}$} & SBU 0 a 2 & 1 & \multirow[t]{2}{*}{ Argila preta } \\
\hline & SBU 6 a 8 & 7 & \\
\hline & SBU 14 & 14 & \multirow[t]{4}{*}{ Areia } \\
\hline & SBU 46 & 46 & \\
\hline & SBU 65 & 65 & \\
\hline & SBU 86 & 86 & \\
\hline & SBU 93 & 93 & \multirow[t]{5}{*}{ Areia siltosa } \\
\hline & SBU 98 & 98 & \\
\hline & SBU 108 & 108 & \\
\hline & SBU 118 & 118 & \\
\hline & SBU 128 & 128 & \\
\hline \multirow{9}{*}{$\begin{array}{l}\text { São João do Cariri } \\
\text { (PB) }\end{array}$} & BES 0 & 0 & \multirow{9}{*}{ Argila arenosa marrom } \\
\hline & BES 20 & 20 & \\
\hline & BES 40 & 40 & \\
\hline & BES 60 & 60 & \\
\hline & BES 80 & 80 & \\
\hline & BES 100 & 100 & \\
\hline & BES 120 & 120 & \\
\hline & BES 140 & 140 & \\
\hline & BES 170 & 170 & \\
\hline
\end{tabular}




\section{VALE DO CATIMBAU - BUÍQUE - PE}

\section{1. Área de estudo}

\subsubsection{Caracterização geográfica}

A área de estudo denominada Vale do Catimbau está inserida no Parque Nacional do Catimbau, delimitado pelas coordenadas $8^{\circ} 24^{\prime} 00^{\prime \prime}$ e $8^{\circ} 36^{\prime} 35^{\prime \prime} \mathrm{S}$ e $37^{\circ} 09^{\prime} 30^{\prime \prime}$ e $37^{\circ} 14^{\prime} 40^{\prime \prime} \mathrm{W}$, entre os municípios de Arcoverde, Buíque, Ibimirim e Tupanatinga, no estado de Pernambuco.

\subsubsection{Caracterização geológica e geomorfológica}

O Município de Buíque, onde se insere o Parque Nacional do Catimbau, localiza-se na Província Borborema, caracterizada por rochas cristalinas do PréCambriano, presente nos complexos Cabrobó, Belém do São Francisco e Vertentes, além de rochas metamórficas e suítes intrusivas. A borda norte dessa área está inserida na Bacia Sedimentar do Jatobá, que apresenta idades que vão do Paleozóico ao Mesozóico constituída por arenitos, que formam a Chapada de São José. Além disso, de idade pleistocênica e holocênica se encontram os depósitos coluviais, eluviais e fluviais quaternários (CPRM, 2005; Hasui, 2012).

O Vale do Catimbau encontra-se inserido na Unidade Geoambiental do Planalto da Borborema, que é formada por maciços e outeiros altos, com altitudes que variam entre 650 a $1.000 \mathrm{~m}$ e possui uma área de arco que se estende do sul de Alagoas até o Rio Grande do Norte. Apresenta um relevo com predomínio de vales profundos e estreitos dissecados (CPRM, 2005). Entre os conjuntos de serras que compõem o relevo de Buíque, destaca-se a Serra de Jerusalém (Figura 11), com altitude máxima de $1.000 \mathrm{~m}$ que se caracteriza como uma chapada arenítica com topo plano e encostas íngremes e recortadas, que formam um vale aberto, onde se encontram os sedimentos turfosos que serão estudados. Adjacente a essa serra encontra-se uma extensa turfeira, mantida por um lençol freático aflorante no contato de rochas sedimentares com o embasamento cristalino (Nascimento 2008).

\subsubsection{Caracterização climática e vegetacional}

O Parque Nacional do Catimbau está situado em região com clima semi-árido, que corresponde ao tipo BSh na classificação climática de Köppen. O trimestre mais chuvoso vai de março a maio, com precipitação total acumulada média de $266 \mathrm{~mm}$ e 
o mês mais chuvoso é março, com precipitação média de $113 \mathrm{~mm}$, já o trimestre mais seco vai de setembro a novembro, com precipitação média de $51 \mathrm{~mm}$, sendo o mês mais seco outubro (12 mm), com a temperatura média anual de $23^{\circ} \mathrm{C}$ (INMET, 2014).

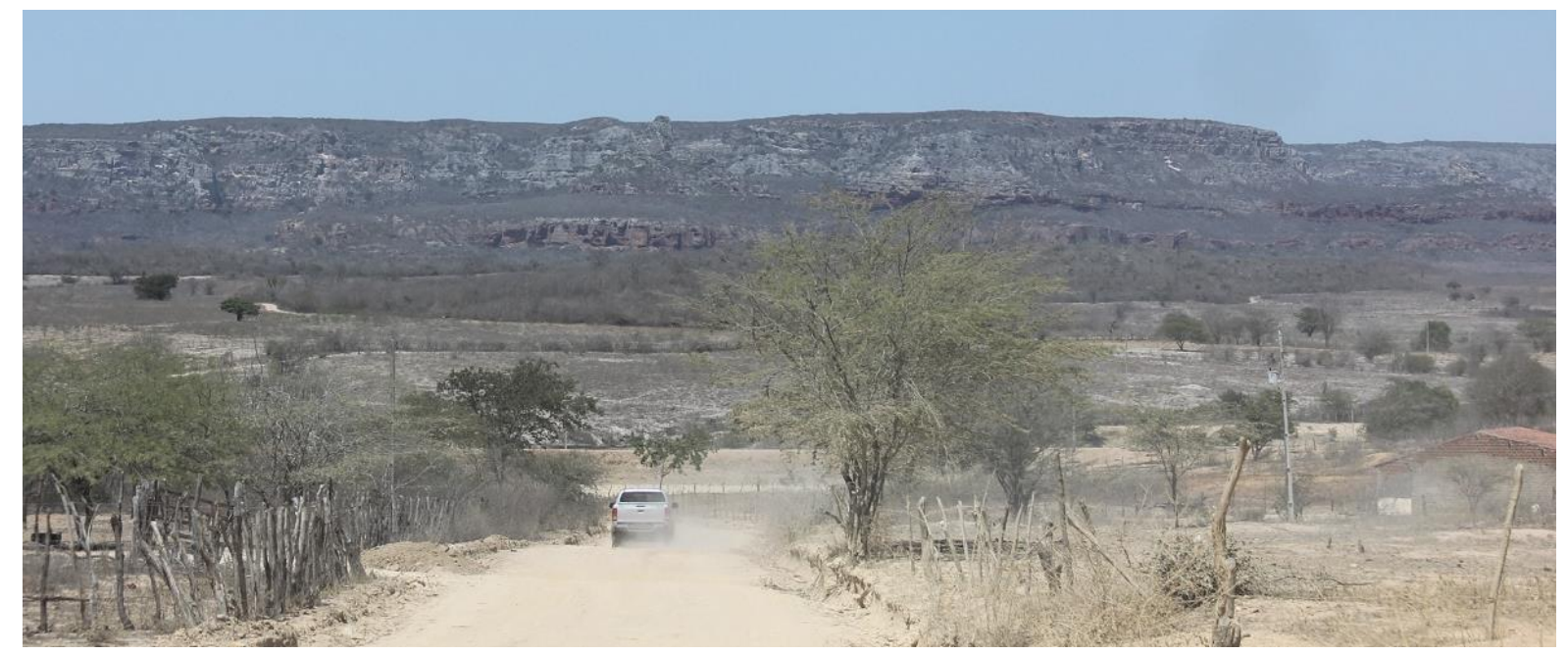

Figura 11. Vista de aproximação do Vale do Catimbau, com a chapada ao fundo, composta por arenitos fluviais da Bacia sedimentar do Jatobá (Paleozoico ao Mesozoico). Foto: Paulo E. de Oliveira.

Em função das variações do relevo e do clima, além de gêneros típicos da Caatinga, como Astronium, Cassia, Ceiba, Cereus, Croton, Jatropha, Manihot e Tabebuia, na região do Parque Nacional do Catimbau foram percebidas, em trabalho de campo, áreas com elementos de Cerrado (Krameria, Hymenaea, Senna, Guapira e Tocoyena) e de florestas (Jacaranda, Clusia, Paralychnophora, Anacardium Justicia, Orbignya e Sauvagesia).

\subsection{Trabalho de campo}

Em fevereiro de 2014 foram coletadas quatro seções sedimentares com testemunhador Russo (Figura 12), no total de $161,5 \mathrm{~cm}$, no Parque Nacional do

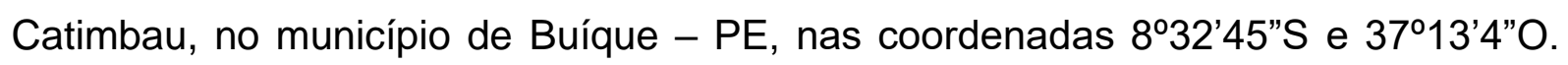
Esta etapa foi realizada por uma equipe liderada pelo Prof. Dr. Marcelo Accioly Teixeira de Oliveira, da Universidade Federal de Santa Catarina (UFSC). 


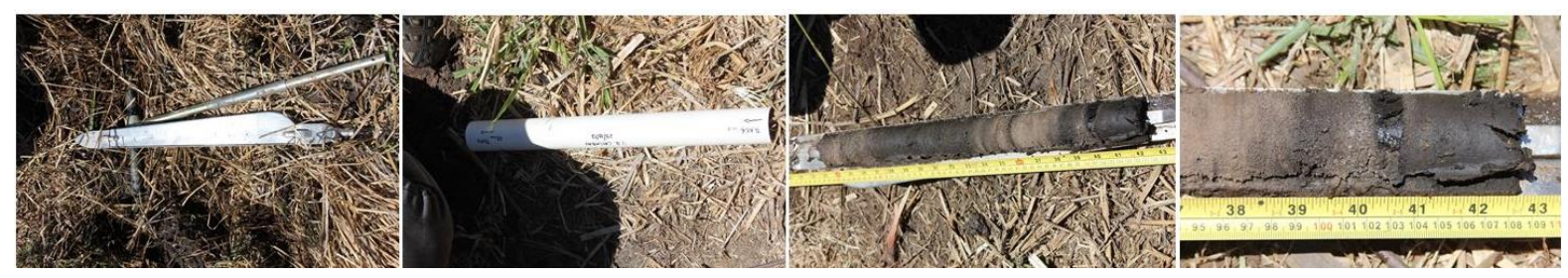

Figura 12. Coleta de sedimentos no Vale do Catimbau com testemunhador Russo. Fotos: Paulo E. de Oliveira.

\subsection{Resultados}

\subsubsection{Litologia e datação}

O testemunho coletado no Vale do Catimbau, composto por $169 \mathrm{~cm}$ de sedimentos turfosos, com base arenosa, de cor preta, apresentou laminações finas de areia, a 122,5 cm e entre 135 e $140 \mathrm{~cm}$ (Tabela 2). As idades radiocarbônicas variaram entre 10.322 e 152 cal anos BP, com inversão de idades por volta dos 1.800 anos (Tabela 3). O modelo de idade (Figura 13) foi elaborado com probabilidade de 95,4\% (2 sigma), pelo Software Oxcal 4.3 (Ramsey, 2008), a calibração das idades foi realizada pelo Software CALIB 7.1 (Stuiver et al., 2017), com os dados SHCAL 13, para o Hemisfério Sul (Hogg et al., 2013) .

Tabela 2. Litologia do Vale do Catimbau

\begin{tabular}{ll}
\hline Profundidade $(\mathrm{cm})$ & Descrição dos sedimentos \\
\hline $0-135$ & Turfa arenosa, com laminação de areia a 122,5 cm \\
$135-140$ & Laminação de areia \\
$140-161,5$ & Turfa arenosa \\
\hline
\end{tabular}

Tabela 3. Idades radiocarbônicas do testemunho do Vale do Catimbau

\begin{tabular}{cccc}
\hline Amostra & Nr. Beta & $\begin{array}{c}\text { Convencional } \\
(\mathrm{BP})\end{array}$ & $\begin{array}{c}\text { Calibrada } \\
\text { (anos cal. BP) 2 } \sigma\end{array}$ \\
\hline 30 & 390149 & $180+/-30$ & 152 \\
60 & 431967 & $1100+/-30$ & 956 \\
80 & 390150 & $1880+/-30$ & 1778 \\
110 & 390151 & $1830+/-30$ & 1714 \\
120 & 431968 & $5700+/-30$ & 6440 \\
130 & 390152 & $6540+/-30$ & 7416 \\
137 & 431969 & $6570+/-30$ & 7446 \\
165 & 370007 & $9200+/-40$ & 10322 \\
\hline
\end{tabular}




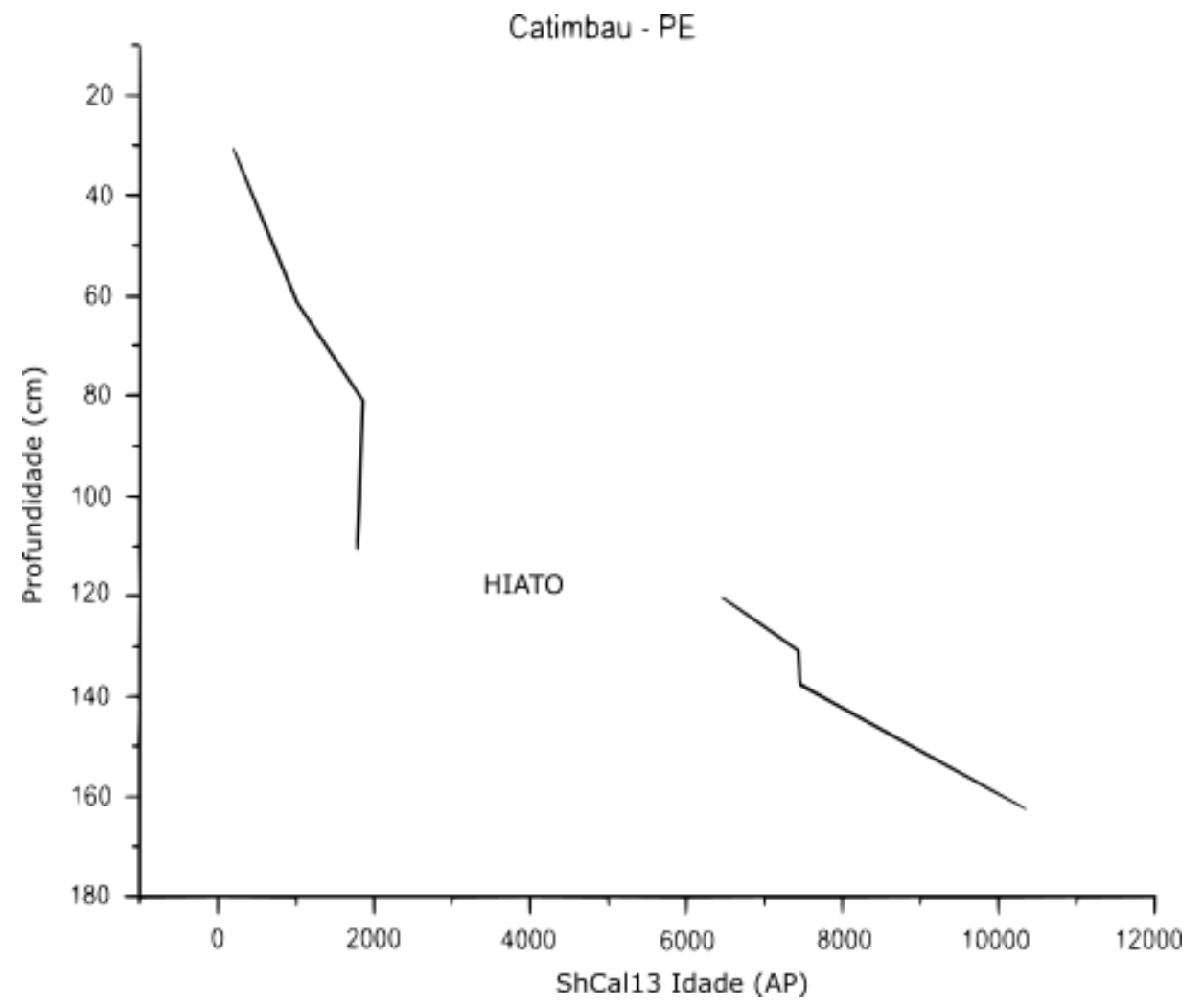

Figura 13. Modelo de idade obtido através do Software Oxcal 4.3 (Ramsey, 2008), com a presença de hiato deposicional entre ca. 6.000 e 2.000 anos cal. AP.

\subsubsection{Palinologia}

Os resultados quantitativos são apresentados na Figura 14, que mostra a porcentagem de taxa selecionados, assim como a soma das categorias de árvores e arbustos, ervas terrestres e aquáticas, esporos e algas, divididos em três ecozonas. A Figura 15 apresenta a concentração das categorias.

O perfil palinológico foi subdividido em zonas polínicas pelo dendrograma gerado pelo subprograma CONNIS, da seguinte forma:

CA-1 (160 - $111 \mathrm{~cm} ; 10,330$ a ca. 6.000 anos cal. AP) é caracterizada por uma tendência geral de aumento, seguido por declínio nos elementos arbóreos, tanto em porcentagem quanto em concentração, no final da zona. Os elementos mais representativos são Arecaceae, Byrsonima (4,6\% - 5,4\% a 0\%), Casearia (1,5\% - 4,5\% a $1,2 \%)$, Cecropia (1\% - $6 \%$ a $1,2 \%)$, Melastomataceae $(1,5 \%-15 \%$ a $1,2 \%)$. A ocorrência de Cecropia nesta zona é significante e pode ser interpretada como um sinal de evento sucessional, após alteração vegetacional, ocorrido devido a climas mais úmidos, ou sugerindo a influência de águas subterrâneas. Grãos de pólen de Orbignya (palmeira), aparece por volta de 9.000 anos cal. BP, com $6 \%$ do total da 
soma polínica, enquanto Ziziphus, um indicador de Caatinga xerófita, flutua nesta zona com valores abaixo de $2 \%$. Os dados de concentração (grãos $/ \mathrm{cm}^{3}$ ) seguem o mesmo padrão de aumento seguido de diminuição, com a preponderância de elementos adaptados à ambiente úmido: Arecaceae (15.724 - 1010), Myrtaceae (1.429 - 2.511 a 167), Cecropia (2.859 - 5.718 a 502), Melastomatace (2.654 - 10.191 a 606) e Orbignya (9.911).

CA-2 (110 - $57 \mathrm{~cm} ; 1,714$ - 956 anos cal. AP). A amostra $110 \mathrm{~cm}$ está na área de contato erosivo entre as camadas retrabalhadas e a não retrabalhada, como sugerido pela inversão de idades e por este motivo não foi inserida na zona anterior, apesar do que mostra o dendrograma, que separou essa profundidade amostral de todas as amostras anteriores devido à reduzida similaridade entre elas.

A zona CA-2 foi subdividida em duas subzonas: entre 110 e $80 \mathrm{~cm}$, correspondente ao intervalo da inversão de idades e retrabalhamento e a sequência não alterada, entre 80 e 57 cm (1.778 a 956 anos cal. AP). Esta última é caracterizada pelo aparecimento de Copaifera, que atinge 4\%, junto com Arecaceae, Celtis e Melastomataceae, em torno de $4 \%$, em sincronia com o aumento de Cecropia, que passa de 3 para 7\% e Piptadenia (>1 a 7\%), além de Simarouba, na casa de 10\%, enquanto Ziziphus continua presente no local, flutuando em torno de $1 \%$. Spathiphyllum que se destaca nesta subzona, devido ao marcado aumento em sua concentração, que atinge $230.300 \mathrm{~g} / \mathrm{cm}^{3}$, é um gênero de ervas encontradas atualmente no local, em rochas muito úmidas que circundam a turfeira. Em contraste a Spathiphyllum, Poaceae e Asteraceae são encontradas em porcentagem e concentração baixas. Orbignya reaparece no perfil, provavelmente como consequência da influência humana, uma vez que este gênero é encontrado em sítios arqueológicos amazônicos, associado à atividade humana, compondo as florestas culturais (Balée, 2013) além de ser nativo da transição floresta amazônica/cerrado (Clement et al., 2005).

Os valores de concentração nesta zona, tendem ao aumento, como no caso dos arbóreos Arecaceae (1.300 a 6.094), Melastomataceae (741 a 13.241), Cecropia (743 a 22.713), Ziziphus (663 a 1.032) e Orbignya (743 a 1.327). Os elementos herbáceos são representados por Asteraceae (2.590 a 11.356) e Poaceae (7.433 a 29.940) e as aquáticas por Borreria (371 a 1.032) e Cyperaceae (743 a 2.617). As 
pteridófitas também apresentam este padrão, com Cyathea (1.486 a 3.097) e esporos triletes (1.672 a 6.694).

CA-3 (56 - $0 \mathrm{~cm}$; 956 anos cal. AP - Presente). Esta zona é dominada pelos elementos arbóreos Arecaceae (0,7 a 3\%), Casearia (2,4 a 0,7\%), Celtis (2 a 13,4\%), Melastomataceae (12 a 9\%), Orbignya que fica em torno de 2,5\% e Piptadenia (2 a 0,2\%). Cecropia e Piper apresentam variações entre $5-29$ e 16\% e $2-4,4$ e $16 \%$ respectivamente. A presença da vegetação de Caatinga na proximidade é representada por Ziziphys, que continua a aparecer em baixa porcentagem $(0,3 \%)$. As taxas de concentração dos elementos arbóreos mantêm o padrão anterior de elevação, com Arecaceae variando de 1.250 a $10.221 \mathrm{~g} / \mathrm{cm}^{3}$, Cecropia passa de 4.385 a $51.106 \mathrm{~g} / \mathrm{cm}^{3}$, Melastomataceae varia de 10.215 a $28.805 \mathrm{~g} / \mathrm{cm}^{3}$ e Orbignya de 2.088 a $9.911 \mathrm{~g} / \mathrm{cm}^{3}$. As ervas são representadas por Asteraceae, que iniciam a zona com 4.176, passam a 10.619 e diminuem para $5.575 \mathrm{~g} / \mathrm{cm}^{3}$, enquanto Poaceae começa com 13.990, diminui para 9.724 e volta a subir para $31.592 \mathrm{~g} / \mathrm{cm}^{3}$, ao mesmo tempo em que as representantes aquáticas Cyperaceae passam de 5.220 para $16.106 \mathrm{e}$ $6.504 \mathrm{~g} / \mathrm{cm}^{3} \mathrm{e}$ a pteridófita Cyathea passa de 30.486 para $1.351 \mathrm{~g} / \mathrm{cm}^{3}$. 


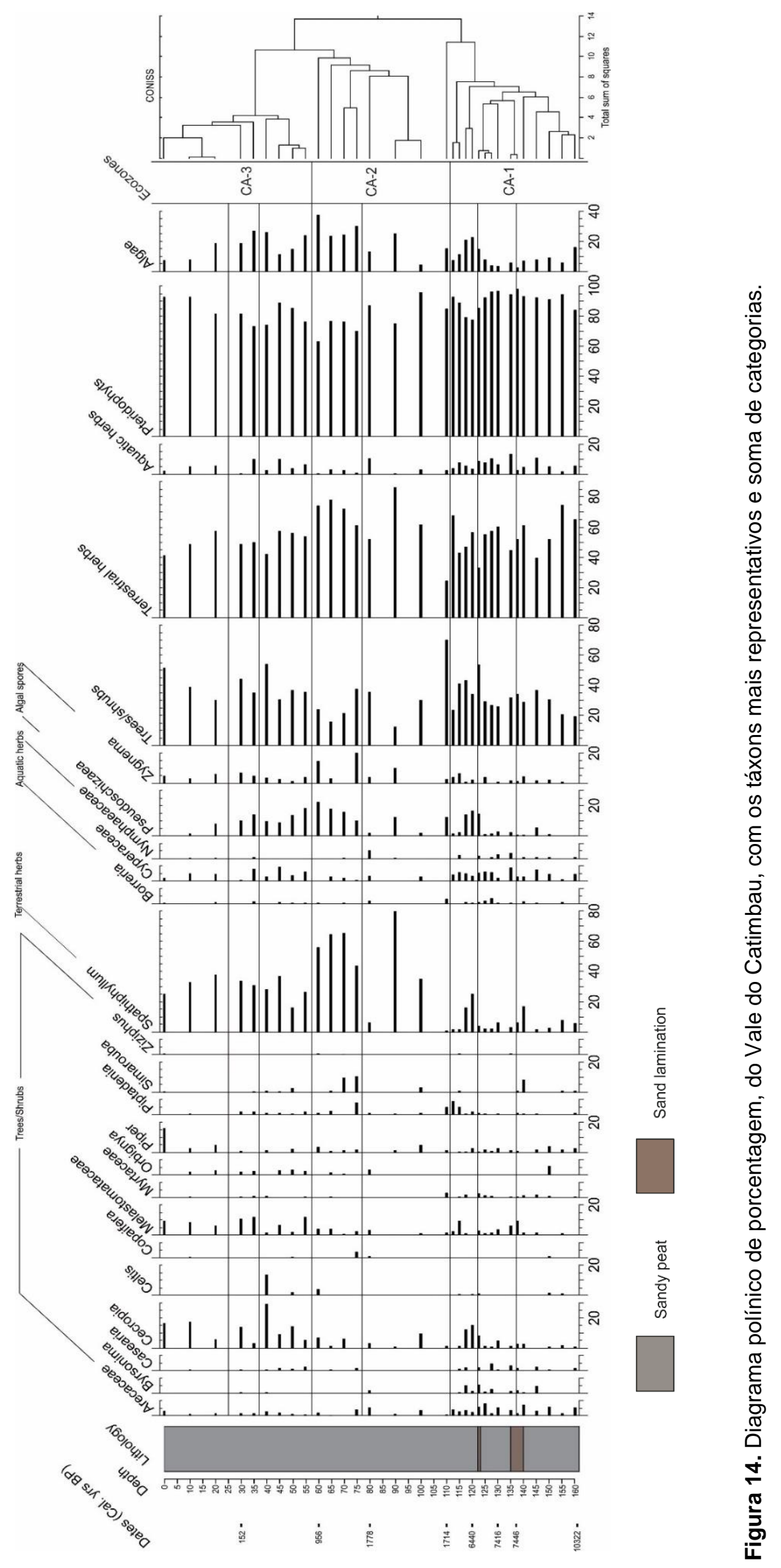




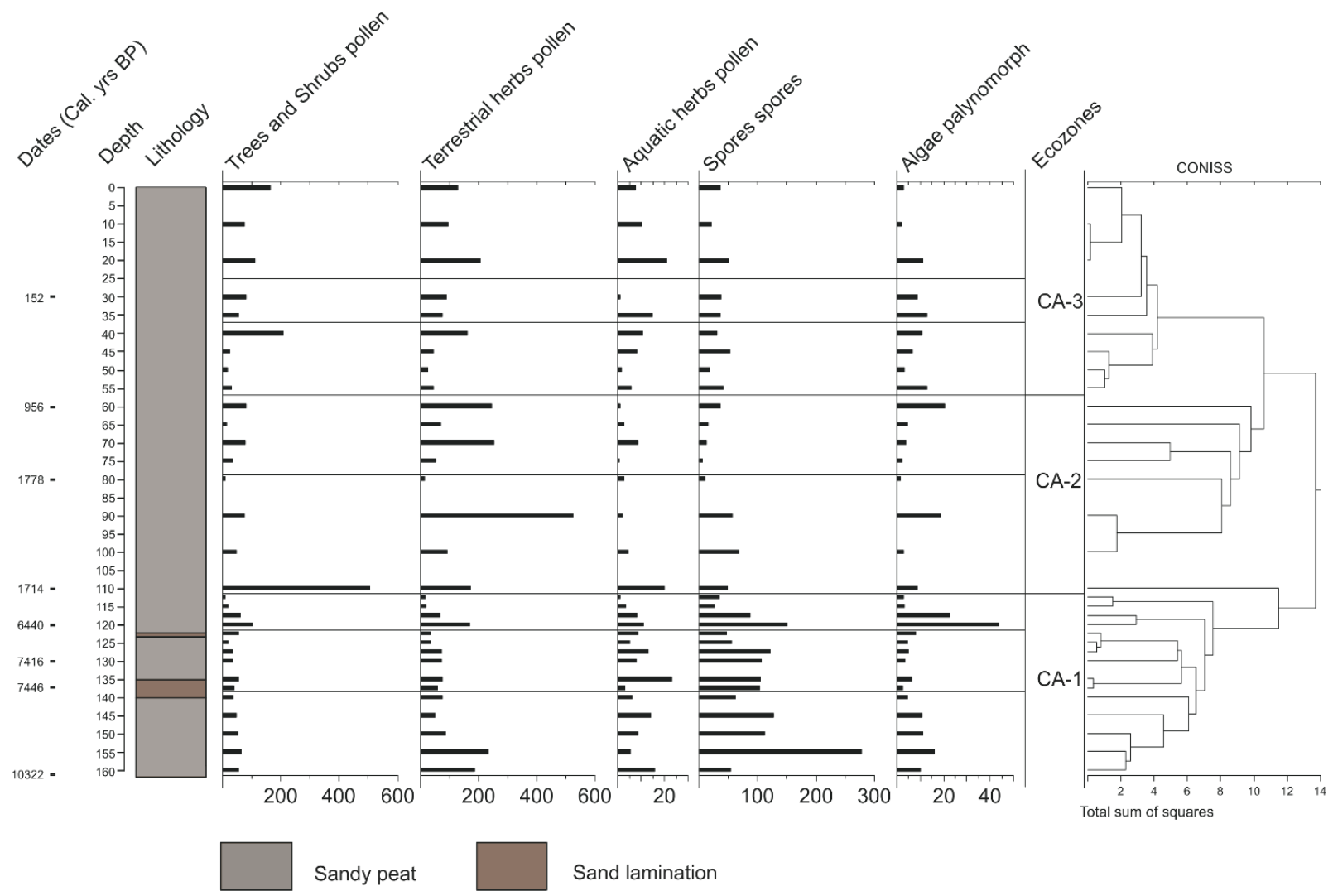

Figura 15. Diagrama polínico de concentração de categorias (x 1000), do Vale do Catimbau. 


\section{IBIMIRIM - PE}

\section{1. Área de estudo}

7.1.1. Caracterização geográfica, geomorfológica e geológica

O município de Ibimirim está situado nas coordenadas 832'26"S e 37041'25” $\mathrm{W}$, com $401 \mathrm{~m}$ de altitude média, com relevo suave ondulado e ondulado, com variação entre 380 e $850 \mathrm{~m}$ e área de 1901,5 Km2. O rio Moxotó e sua bacia hidrográfica abrangem quase toda a área do município, com $1893 \mathrm{~km}^{2}$.

O município possui cerca de $75 \%$ de sua área dentro da bacia sedimentar do Jatobá, que apresenta idades que vão do Paleozóico ao Mesozóico, composta basicamente por arenitos, que se acumulam em um graben. O restante do território é composto por rochas cristalinas, como gnaisses, migmatitos e granitos (Temóteo, 2000).

\subsubsection{Caracterização climática e vegetacional}

O município está situado em região com clima semiárido, do tipo BSh da classificação de Köppen. O trimestre mais chuvoso vai de fevereiro a abril, com precipitação total acumulada média anual de $513,1 \mathrm{~mm}$, o mês mais chuvoso é março, com precipitação média de $124 \mathrm{~mm}$, já o trimestre mais seco vai de agosto a outubro, com precipitação média de $21,9 \mathrm{~mm}$, com o mês de setembro sendo o mais seco $(6,67$ mm). A temperatura média anual é de 25ํㅡ (Temóteo, 2000).

No município prevalece a vegetação hiperxerófita, com predomínio de espécides arbóreas pertencentes aos gêneros Spondias, Commiphora, Pilosocereus, Caesalpinia, Cnidosculus e Piptadenia; das arbustivas Senna, Croton, Jatropha, Bocoa e Pavonia; e das herbáceas Ipomoea, Sida e Herissantia (Rodal et al., 1999).

\subsection{Trabalho de campo}

No Município de Ibimirim - PE, foram amostrados sedimentos da Lagoa do Puiú. Na ocasião da coleta, a lagoa estava seca (Figura 16) e por este motivo foi escavada uma trincheira de $1,5 \times 1,5 \mathrm{~m}$, nas coordenadas $8^{\circ} 36^{\prime} 09^{\prime \prime} \mathrm{S}$ e $37^{\circ} 27^{\prime} 37^{\prime \prime} \mathrm{O}$. Ao atingir a profundidade de $140 \mathrm{~cm}$ de profundidade, começou a minar água e por este motivo a escavação foi interrompida. Uma das paredes do depósito foi limpa e o perfil sedimentar foi descrito e amostrado in situ, a intervalos de $5 \mathrm{~cm}$, do topo para a base. 
Não foi possível continuar a amostragem após $135 \mathrm{~cm}$, uma vez que o pisoteio dos amostradores fez com que se formasse um lamaçal no fundo da trincheira, com 0 retrabalhamento dos sedimentos entre os níveis 135 e $160 \mathrm{~cm}$. Na tentativa de aumentar a quantidade de sedimentos coletados, improvisou-se a utilização do amostrador Livingstone (Colinvaux et al., 1999), uma vez que havia água subterrânea infiltrada e os sedimentos estavam friáveis (Figura 17). O perfil sedimentar totalizou a profundidade de $235 \mathrm{~cm}$, com a interrupção mencionada acima, que corresponde a $25 \mathrm{~cm}$.

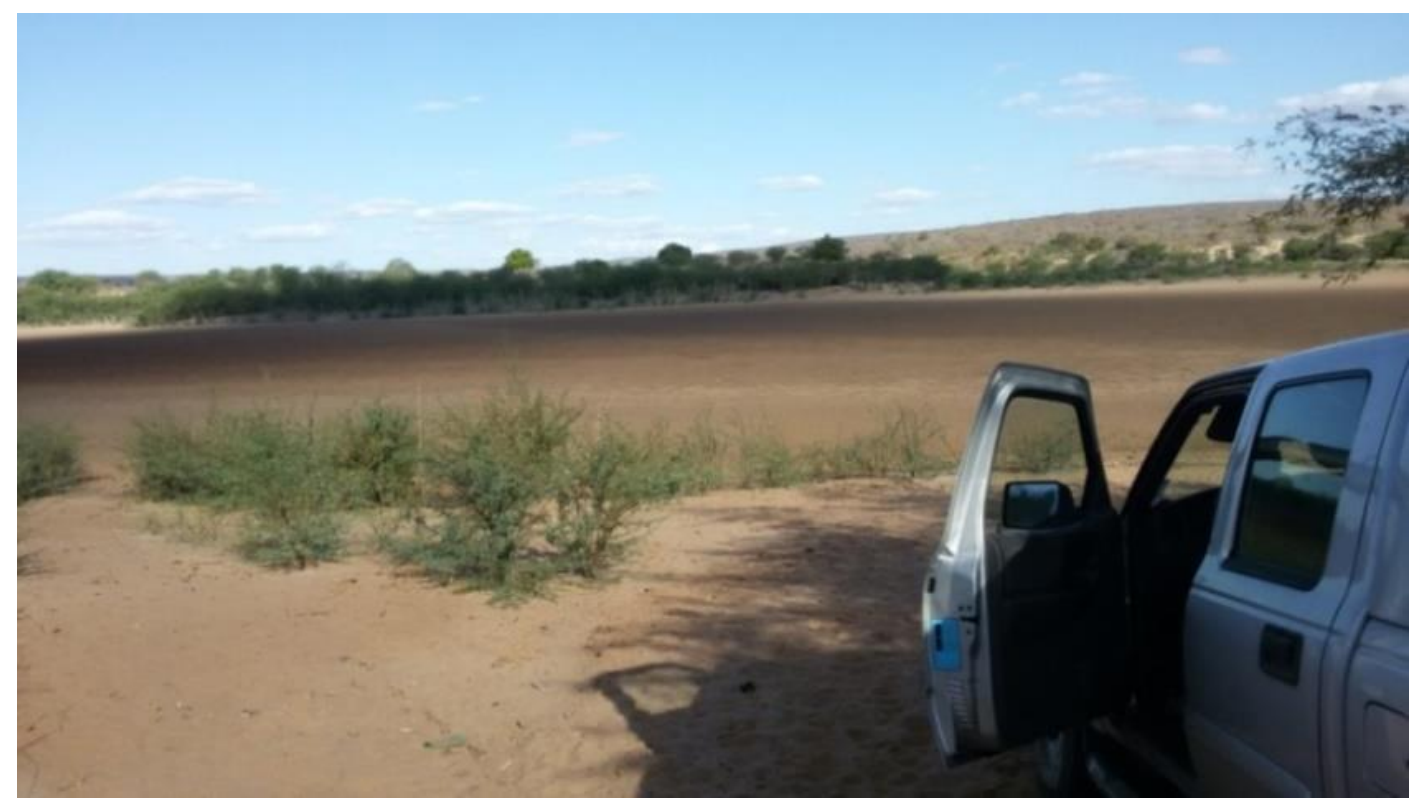

Figura 16. Lagoa do Puiú, situada no município de Ibimirim (PE). Foto: Vanda B. de Medeiros

\subsection{Resultados}

\subsubsection{Litologia e datação}

A trincheira aberta na Lagoa do Puiú, com $135 \mathrm{~cm}$ de profundidade, apresentou sedimentos argilosos avermelhados, com intervalos pretos e outros mosqueados, com a presença de gastrópodes planorbídeos nos primeiros $35 \mathrm{~cm}$, a partir do topo. A 5 $\mathrm{cm}$ de profundidade notou-se uma camada de sal e a $30 \mathrm{~cm}$ uma de argila nodular. Os $74 \mathrm{~cm}$ de sedimentos coletados com o amostrador Livingstone eram compostos pela mesma argila avermelhada mosqueada (Figura 18). A datação obtida na base do testemunho, correspondente a $234 \mathrm{~cm}$ de profundidade foi de $781 \pm 23$ anos AP. 

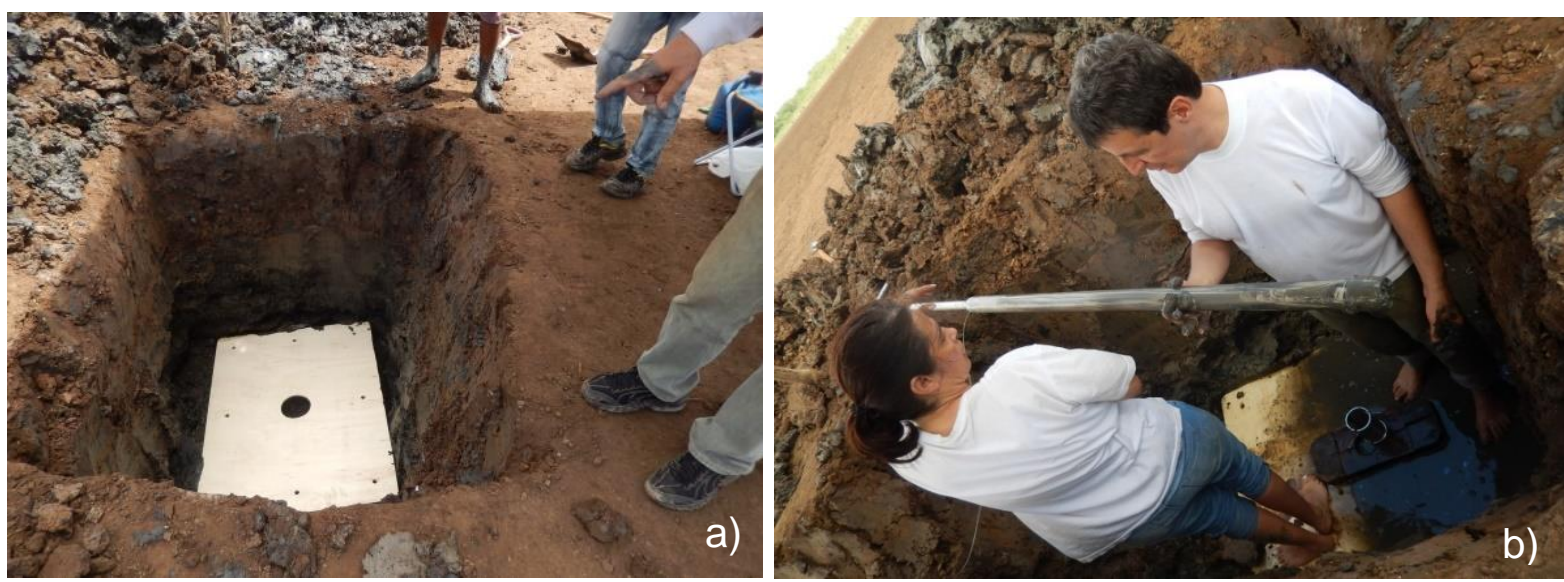

Figura 17. Coleta de sedimentos na Lagoa do Puiú, município de Ibimirim (PE). a) Trincheira escavada; b) Coleta de testemunho com amostrador Linvigstone. Fotos: Vanda Medeiros e Alcina F. Barreto respectivamente

\subsubsection{Microfósseis}

Apesar de análises prévias demostrarem a presença de grãos de pólen, tais como Poaceae, Zygnema e alguns triletes de Pteridófitas nos sedimentos, optou-se por descartá-los, devido à baixa idade radiocarbônica obtida. 


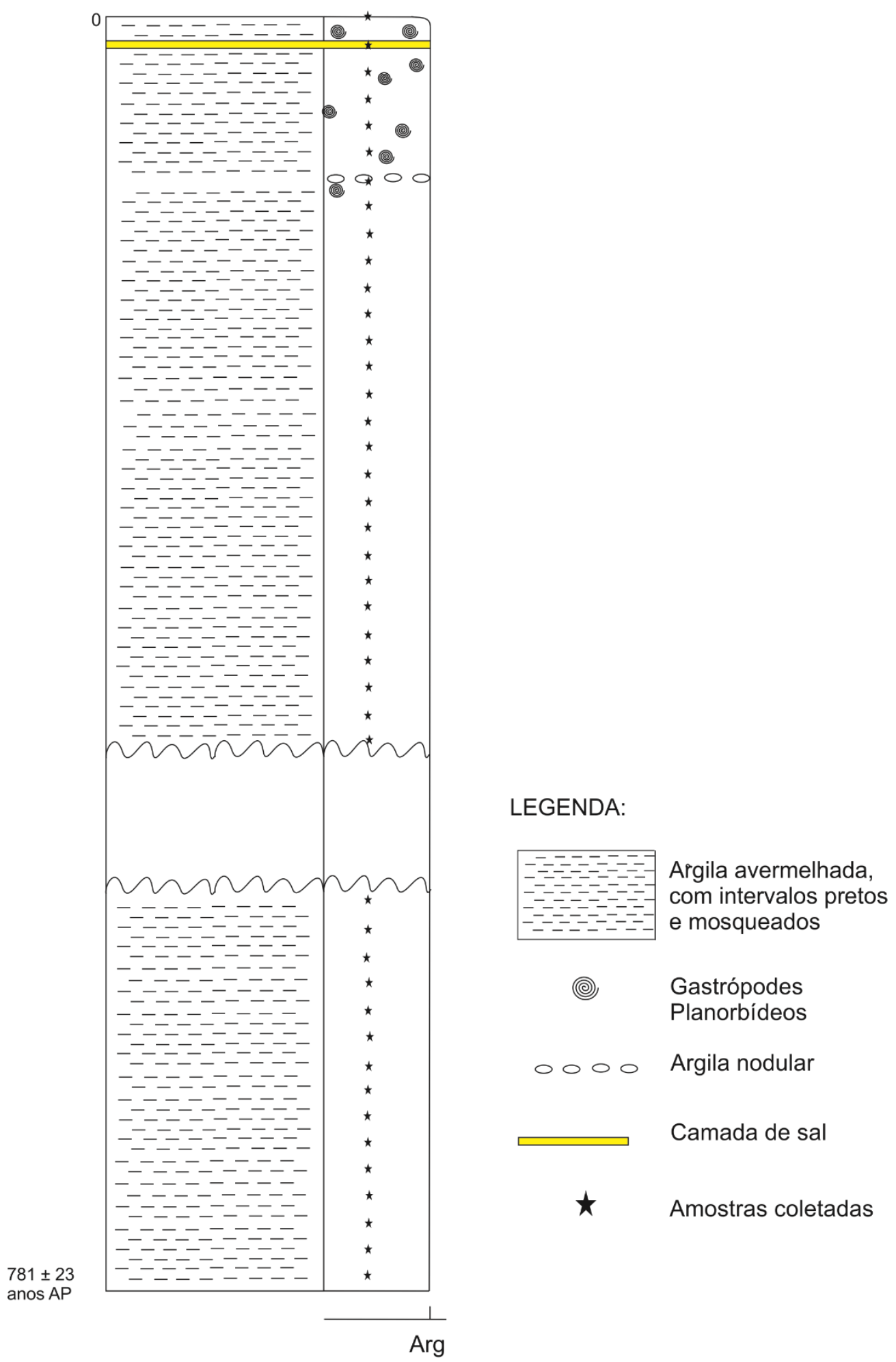

Figura 18. Seção estratigráfica com localização das amostras coletadas na Lagoa do Puiú - Ibimirim PE. 


\section{CAPOEIRAS - PE}

\section{1. Área de estudo}

8.1.1. Caracterização geográfica, geomorfológica e geológica

O município de Capoeiras está situado nas coordenadas $8^{\circ} 44^{\prime} 05^{\prime \prime S}$ e 3637'36"W, com $888 \mathrm{~m}$ de altitude média, e área de $342,9 \mathrm{Km} 2$. Faz parte da unidade geoambiental do Planalto da Borborema, com altitudes que variam de 650 a $1000 \mathrm{~m}$. É recortado por rios de pequena vazão, todos perenes, com relevo movimentado, caracterizado pela formação de vales (Mascarenhas et al., 2005b).

Geologicamente o município está inserido na Província Borborema, formado pelos complexos Cabrobó e Belém do São Francisco, do Mesoproterozóico e de Suíte Intrusiva do Neoproterozóico. (Mascarenhas et al., 2005b).

\subsubsection{Caracterização climática e vegetacional}

Situado no agreste pernambucano, o município possui clima tropical chuvoso, com verão seco, do tipo As da classificação de Köppen. O trimestre mais chuvoso vai de março a maio, com precipitação total acumulada média anual de $730 \mathrm{~mm}$. O mês mais chuvoso é abril, com precipitação média de $109 \mathrm{~mm}$, já o trimestre mais seco vai se setembro a novembro, com precipitação média de $69 \mathrm{~mm}$, sendo o mês de outubro o mais seco (17 mm). A temperatura média anual é de 20,5ㄷ․

Apesar de estar classificado em um clima tropical chuvoso, o município está inserido na região do semiárido, uma vez que o acumulado de pluviosidade não ultrapassa os $800 \mathrm{~mm}$ por ano. A vegetação encontrada neste local é caracterizada por espécies dos gêneros Anadenanthera, Aspidosperma, Cereus, Commiphora, Cynophalla, Hadroanthus, Jatropha, Libidibia, Mimosa, Myracrodruon, Piptadenia, Schinopsis, Sideroxylon, Spondias, Syagrus e Zizyphus joazeiro (ITP, 2014).

\subsection{Trabalho de campo}

Durante a primeira visita ao município de Capoeiras - PE, foi realizada a prospecção em uma cacimba com restos evidentes de megafauna, situada nas coordenadas $8^{\circ} 43^{\prime} 15^{\prime \prime}$ e e 36038'20"O. No interior da cacimba havia uma lâmina de água, mas era possível a visualização de que o local já havia sido escavado anteriormente e que o depósito já não apresentava a totalidade de seus sedimentos (Figura 19). 
Desta forma, um novo trabalho de campo foi realizado um mês e meio depois, após o dessecamento da cacimba, pois o proprietário solicitou a escavação do local para aumentar a capacidade de armazenamento de água. Para tanto, a prefeitura do município disponibilizou uma retroescavadeira, desde que as ossadas fossem retiradas para estudo pela UFPE. Neste trabalho de campo foi realizada a remoção de ossadas e dentes de megafauna, assim como sedimentos correlatos, para análise micropaleontológica (Figura 20).

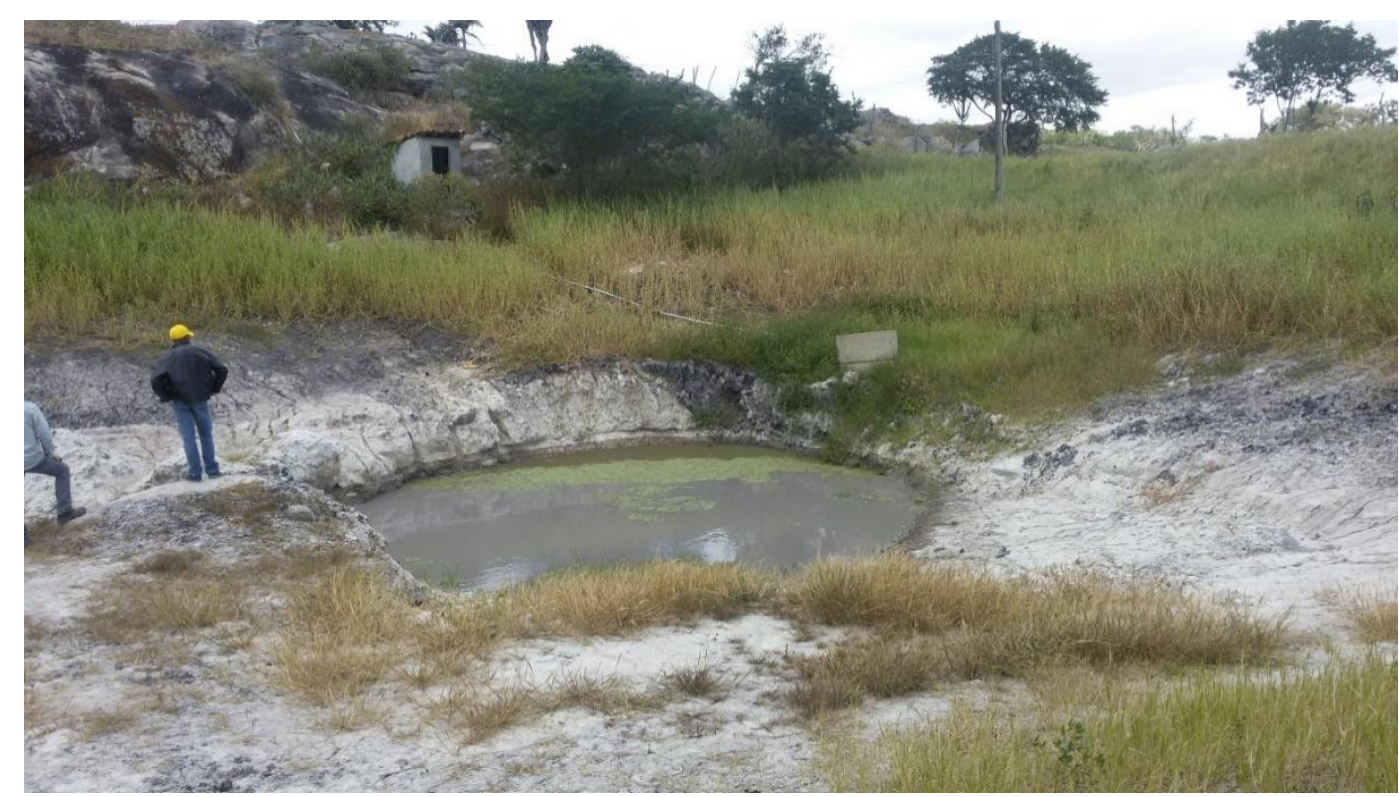

Figura 19. Cacimba localizada no município de Capoeiras (PE), com lâmina d'água em setembro/2015. Foto: Vanda B. de Medeiros

\subsection{Resultados}

\subsubsection{Litologia e datação}

Os sedimentos coletados nesta localidade correspondem a uma seção, de 250 $\mathrm{cm}$ de espessura, composta por unidades litológicas de pontos diferentes da cacimba, que revelou a presença de sedimentos basais silte-arenosos sobrepostos por uma camada de conglomerado, onde se encontram vários fragmentos de ossos e alguns ossos inteiros, assim como osteodermos (partes de carapaça de Glyptodon), integrantes da megafauna local entre 170 e $210 \mathrm{~cm}$ de profundidade. Dessa camada em direção ao topo são encontrados sedimentos arenosos, marcados por bioturbação, seguidos de uma sequência de argilito escuro (Figura 21). A idade radiocarbônica realizada em amostra coletada no meio da camada composta por conglomerados e ossos (entre 212 e $217 \mathrm{~cm}$ ) apresentou a idade de 9.388 anos cal. AP. 


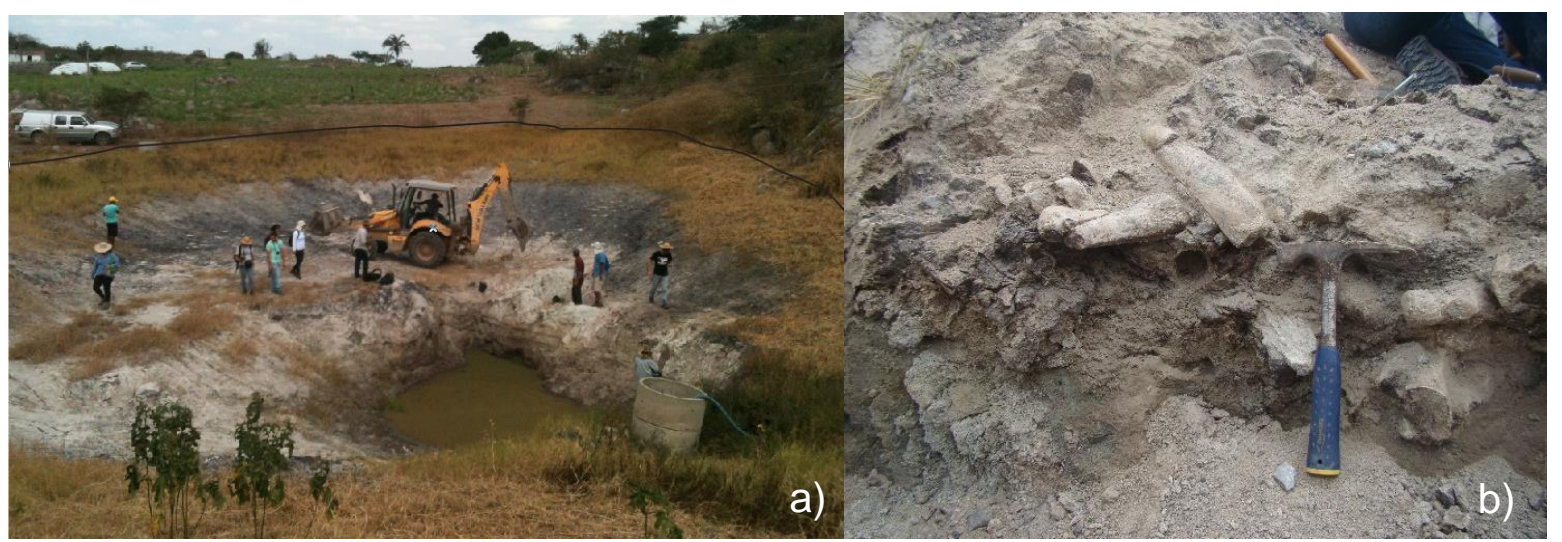

Figura 20. Cacimba localizada na Fazenda Currais Queimados, em Capoeiras (PE). a) Local onde foi realizada a escavação. O traçado na imagem reflete a extensão da área de ocorrência de sedimentos na cacimba; b) Camada contendo ossadas de megafauna e seus sedimentos correlatos. Fotos: Vanda B. de Medeiros

\subsubsection{Microfósseis}

A análise palinológica referente a esta localidade concentrou-se na camada rica em fragmentos de ossos da megafauna, em três amostras de areia aparentemente orgânicas, no entanto, as três foram inférteis. Não foram realizadas análises de diatomáceas nem de fitólitos para esta localidade.

\subsubsection{Isótopos de Carbono e Nitrogênio}

Os resultados de isótopos revelaram baixíssimo teor de COT, menor que 3\%, com incremento nas amostras superficiais, correlacionados a aumento de NT e da razão $\mathrm{C} / \mathrm{N}$, assim como com o enriquecimento do $\delta^{13} \mathrm{C}$ (Figura 22). Em geral, a vegetação da base desta localidade é de plantas $\mathrm{C} 3$, e a origem do Nitrogênio nos corpos d'água é proveniente de algas. A vegetação da seção de sedimentos relacionada à argila é composta por elementos C4 e/ou CAM, do limite entre as camadas até a superfície e o corpo d'água presente na região tem seu Nitrogênio originado de plantas vasculares terrestres. 


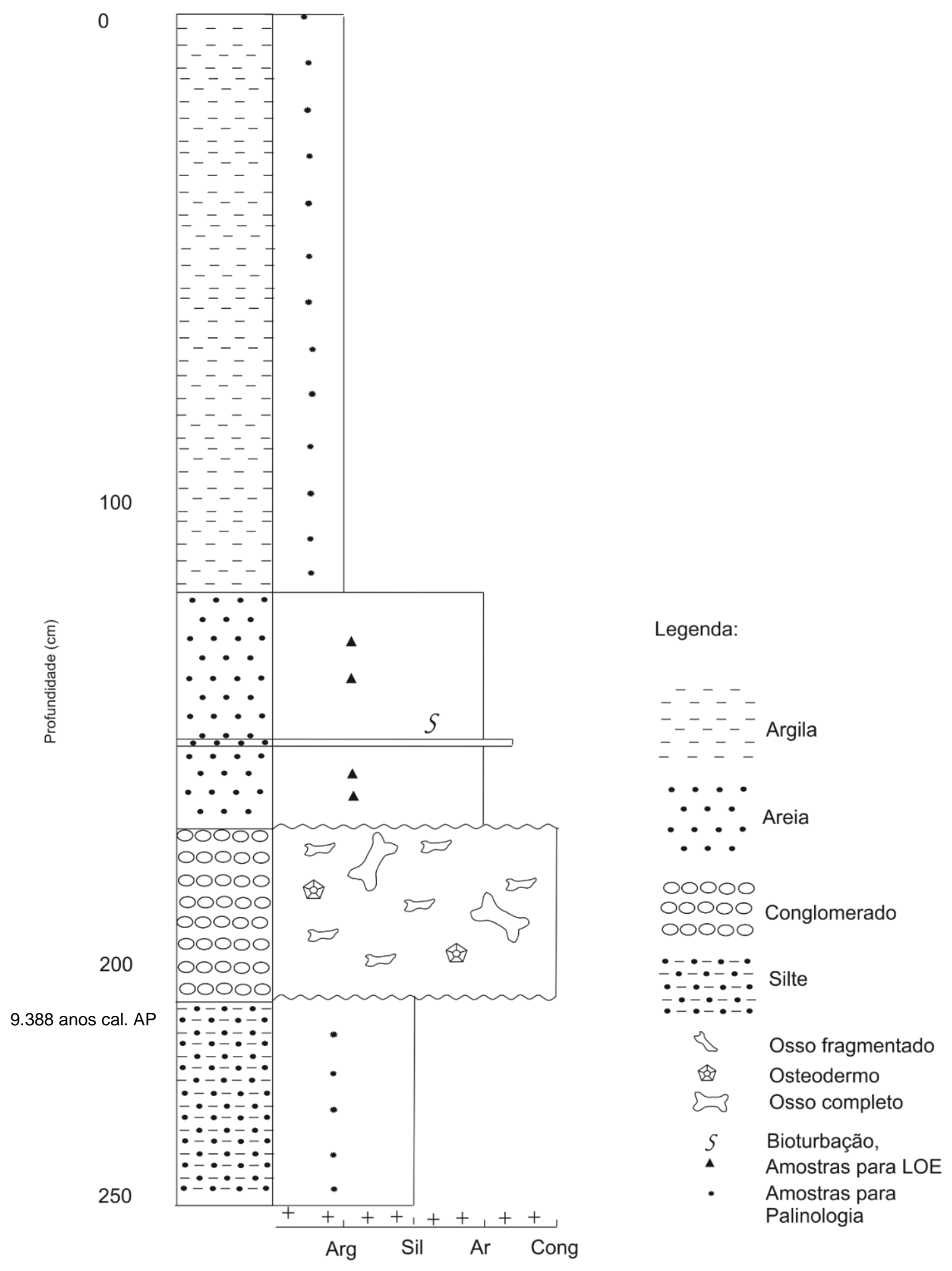

Figura 21. Coluna estratigráfica do ponto de coleta em Capoeiras - PE. 


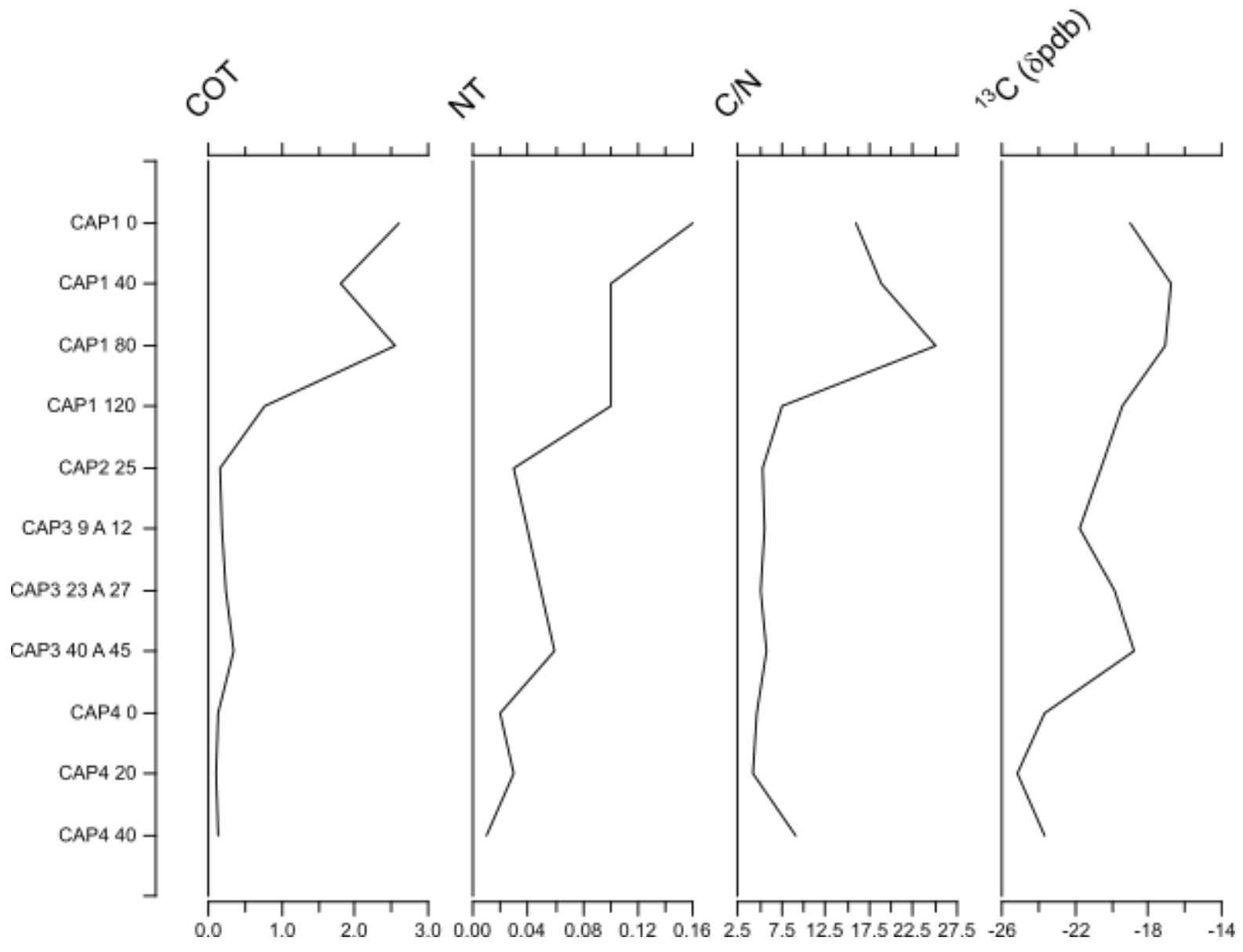

Figura 22. Perfil de COT, NT e C/N ao longo do testemunho da localidade de Capoeiras - PE 


\section{SÃO BENTO DO UNA - PE}

\section{1. Área de estudo}

9.1.1. Caracterização geográfica, geomorfológica e geológica

O município de São Bento do Una se localiza entre as coordenadas 8³1'22"S e 3606'40"W, com altitude média de $614 \mathrm{~m}$ e área de $712,9 \mathrm{~km}^{2}$. Faz parte da unidade geoambiental do Planalto da Borborema, com altitudes que variam de 650 a $1000 \mathrm{~m}$. É recortado por rios de pequena vazão, todos perenes, com relevo movimentado, caracterizado pela formação de vales (Mascarenhas et al., 2005b).

Geologicamente o município está inserido na Província Borborema, formado pelos complexos Cabrobó e Belém do São Francisco, do Mesoproterozóico e de Suíte Intrusiva do Neoproterozóico e pelo litotipo da Suíte Serra de Taquaritinga (Mascarenhas et al., 2005b).

\subsubsection{Caracterização climática e vegetacional}

Situado no agreste pernambucano, o município possui clima tropical chuvoso, com verão seco, do tipo As da classificação de Köppen, a temperatura média anual é de $22^{\circ} \mathrm{C}$ e a precipitação total acumulada média anual é de $653 \mathrm{~mm}$. O trimestre mais chuvoso vai de março a maio, com média de $107 \mathrm{~mm}$ em abril e o trimestre mais seco vai de setembro a novembro, com $16 \mathrm{~mm}$ em outubro.

Apesar de estar classificado em um clima tropical chuvoso, o município está inserido na região do semiárido, uma vez que o acumulado de pluviosidade não ultrapassa $800 \mathrm{~mm}$ por ano. A vegetação encontrada neste local é caracterizada por espécies pertencentes aos gêneros Anadenanthera, Aspidosperma, Cereus, Commiphora, Cynophalla, Hadroanthus, Jatropha, Libidibia, Mimosa, Myracrodruon, Piptadenia, Schinopsis, Sideroxylon, Spondias, Syagrus e Zizyphus joazeiro (ITP, 2014).

\subsection{Trabalho de campo}

No município de São Bento do Una - PE, nas coordenadas 8³7'43.2”S e $36^{\circ} 30^{\prime} 11.5^{\prime} \mathrm{W}$, com altitude de $840 \mathrm{~m}$, em cacimba com fósseis de megafauna, foram coletados sedimentos presentes sob uma camada de arenito calcífero (Figura 23). perfil coletado não segue um padrão contínuo de amostragem, devido à estratigrafia do local. A importância desta coleta deve-se à presença notória de ossadas de 
megafauna no local, coletadas por pesquisadores do Museu de História Natural de Taubaté, assim como uma datação por LOE (Luminescência Oticamente Estimulada) realizada previamente no arenito calcífero, com idade de aproximadamente 17.000 anos AP (Tatumi et al., 2015).

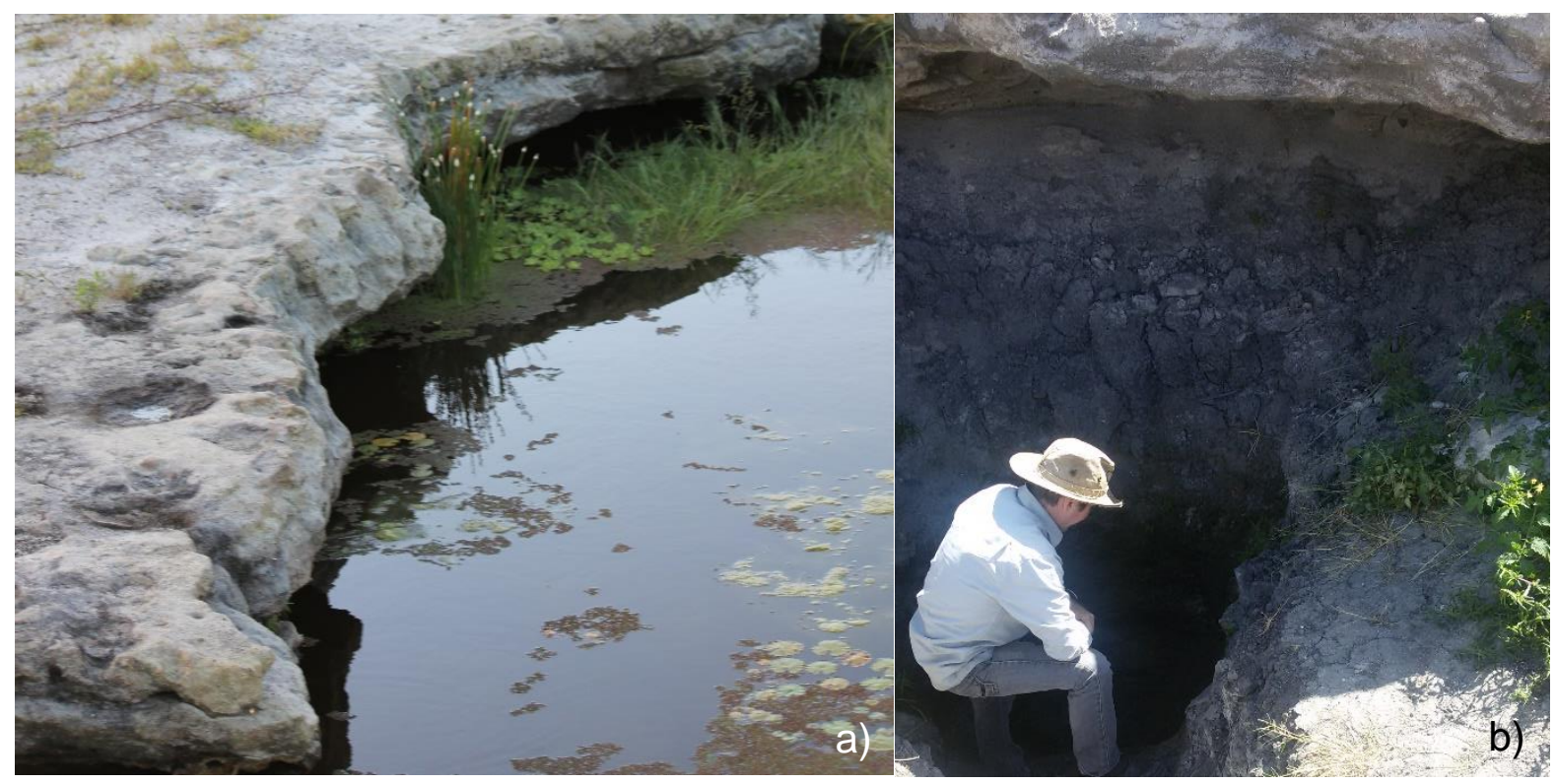

Figura 23. Cacimba localizada no município de São Bento do Una (PE). a) Foto de jul/2014, época em que estava cheia, após período de chuvas; b) Foto de set/2015, em período de seca, quando foi feita a coleta de sedimentos no local. Fotos: Paulo E. de Oliveira e Vanda B. de Medeiros, respectivamente

No total foram coletadas 17 amostras, sem intervalos fixos entre elas, em frações onde percebia-se, a olho nu, camadas mais escuras, possivelmente indicativas de deposição de matéria orgânica.

\subsection{Resultados}

\subsubsection{Litologia e datação}

Os sedimentos coletados nesta localidade perfazem um perfil composto, com $128 \mathrm{~cm}$ de profundidade. Este depósito sedimentar está inserido sob uma laje de arenito calcífero de $70 \mathrm{~cm}$ de espessura (Figura 24), impregnada de ossos de megafauna e datada por LOE, cuja idade varia entre 15.700 e 19.600 anos AP (Tatumi et al., 2015). Os primeiros oito centímetros de espessura são compostos por uma camada laminada de argila preta, seguida de uma camada de areia, com osteodermos e fragmentos de ossos, de $\sim 80 \mathrm{~cm}$ de espessura, interrompida por uma camada de cascalho (gnaisse) e mais $40 \mathrm{~cm}$ de areia argilosa (Figura 25). As idades radiocarbônicas variaram, de forma descontínua, entre 108 anos cal. AP e 34.935 
anos cal. AP, conforme a tabela 4 e o modelo de idade (Figura 26), obtido através do Software Bacon (Blaauw e Christen, 2011), com probabilidade de $95 \%$ e curva de calibração SHCAL13 (Hogg et al., 2013).

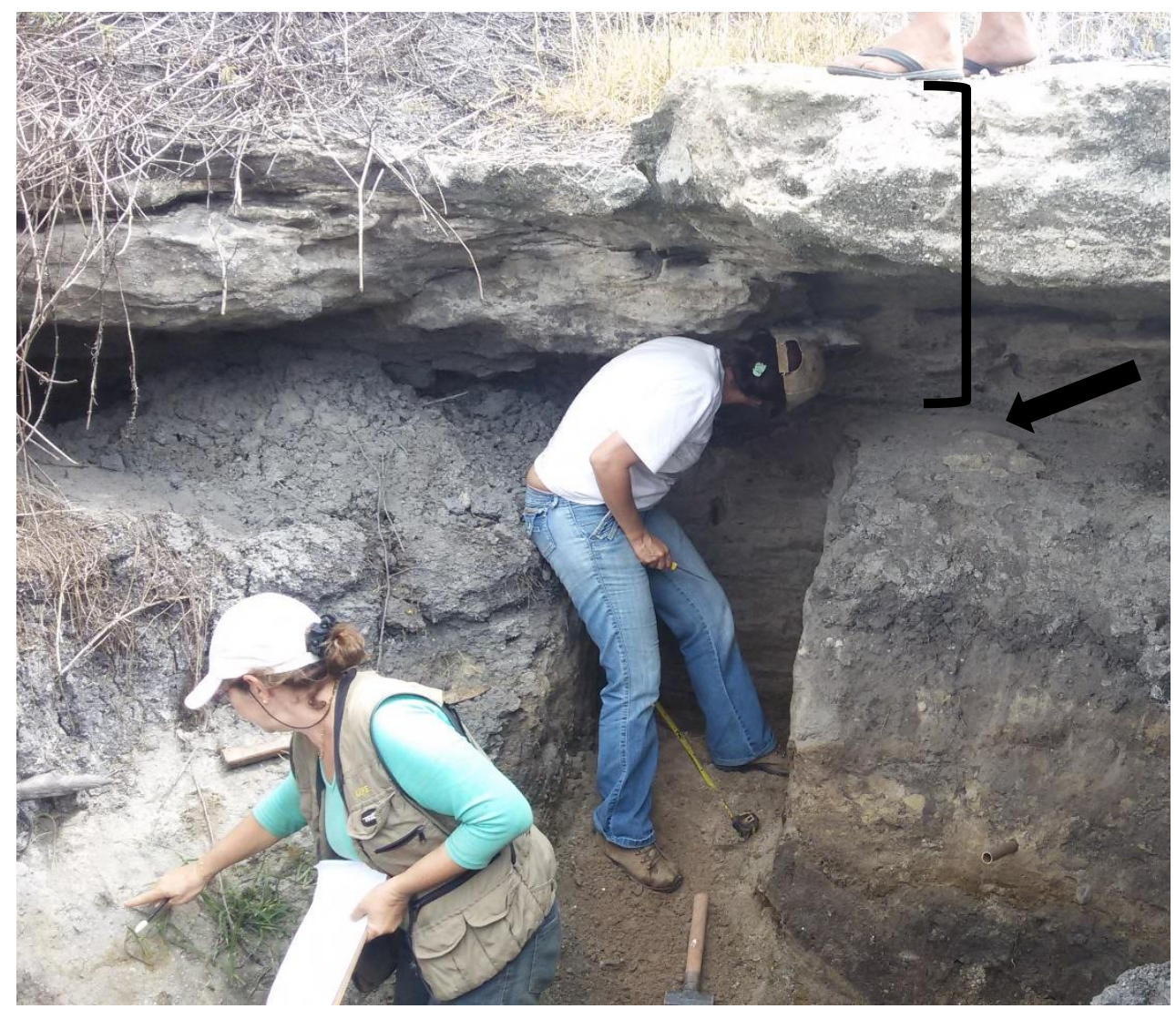

Figura 24. Trincheira escavada no município de São Bento do Una. O colchete em preto destaca a laje de arenito calcífero, com $70 \mathrm{~cm}$ de espessura e a seta aponta a superfície dos sedimentos coletados. Foto: Paulo E. de Oliveira

Tabela 4. Idades radiocarbônicas do perfil sedimentar de São Bento do Una - PE

\begin{tabular}{|c|l|c|c|}
\hline Amostra $(\mathrm{cm})$ & Nr. Laboratório & Idade 14C & Idade Calibrada (anos cal. AP) \\
\hline 1 & BETA 509064 & $210 \pm 30$ & 108 \\
\hline 14 & BETA 509065 & $1530 \pm 30$ & 1375 \\
\hline 93 & BETA 509066 & $8760 \pm 40$ & 9685 \\
\hline 128 & UGAMS 28377 & $32959 \pm 185$ & 34935 \\
\hline
\end{tabular}



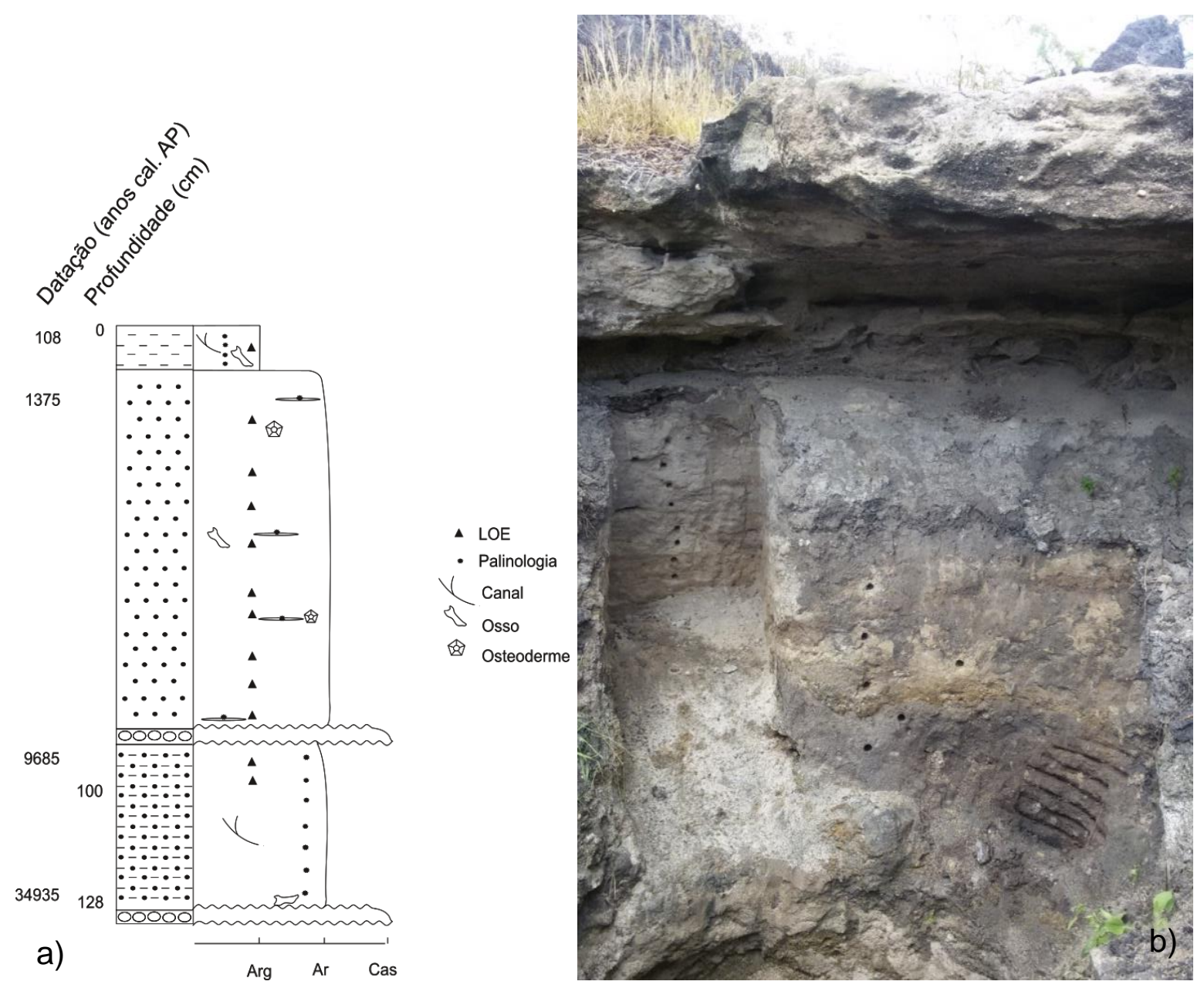

Figura 25. Perfil coletado no povoado de Tamanduá de Cima, no município de São Bento do Una PE. a) Seção estratigráfica da cacimba, com a sinalização dos locais de amostragem para análises palinológicas e idades calibradas; b) Cacimba após a limpeza do perfil e coleta de amostras. 
As idades radiocarbônicas são coerentes entre si e sem sinal de inversões. Este depósito sedimentar depositado sob a camada de arenito calcífero, datada em média com 17.000 anos AP, pode ser interpretada como uma segunda fase de deposição. Uma deposição anterior, que culminou com a deposição da camada de areia com carbonato de cálcio, que em algum momento mais seco precipitou e promoveu a cimentação do pacote, formando uma laje. Um possível cenário hipotético que poderia explicar a discrepância de idade entre o arenito calcífero e os sedimentos abaixo desse nível envolveria a remoção desses sedimentos inconsolidados por um episódio de grande umidade, que deixou uma cavidade aberta, que foi posteriormente preenchida por sedimentos em outros episódios de grande umidade. Tal explicação se faz coerente, uma vez que a amostra basal é mais antiga que a obtida na camada de arenito calcífero. Além disso, a camada mais superficial, composta por argila, que obteve idade muito recente (108 anos cal. AP), não tem contato direto com a camada superior, de arenito calcífero (Figura 27). Este fato sugere que houve a formação de um pequeno lago que depositou material mais fino na superfície.

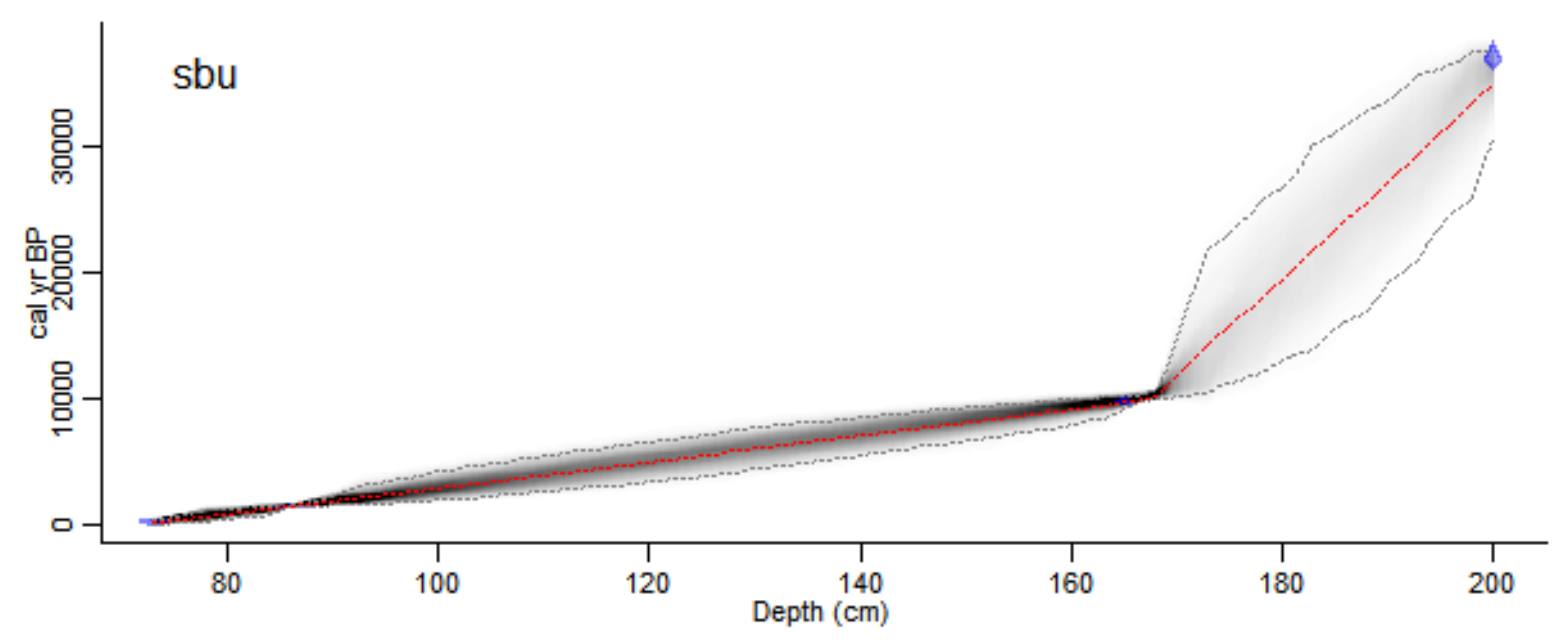

Figura 26. Modelo de idade, obtido através do pacote Rbacon (Blaauw e Christen, 2011). 


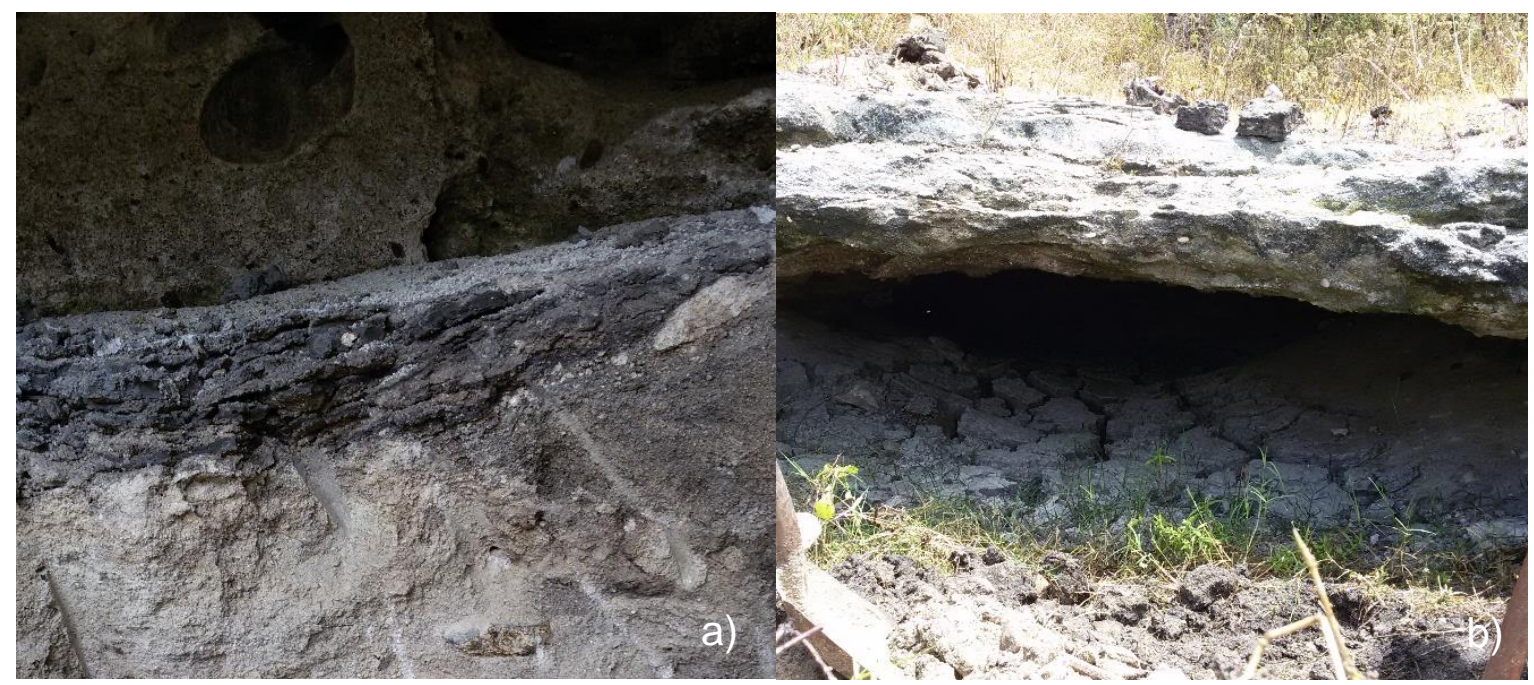

Figura 27. Cacimba em São Bento do Una. a) Local escavado para a coleta de sedimentos; b) Fácie similar ao ponto escavado, na mesma localidade, com a visualização da camada de argila sob o arenito calcífero, cheia de gretas, em período de seca. Fotos: Vanda B. de Medeiros.

\subsubsection{Palinologia}

As figuras 28 e 29 apresentam dados de porcentagem dos elementos arbóreos e herbáceos, respectivamente. Já a figura 30 mostra a porcentagem e a 31 a concentração das categorias arbóreas, ervas terrestres e aquáticas, Azolla, pteridófitas, algas e grãos não identificados, assim como a litologia, palinozonas e dendrograma CONISS.

O subprograma CONISS reconheceu três ecozonas: SBU1 $(200-162 \mathrm{~cm})$, SBU2 $(162-90 \mathrm{~cm})$ e SBU3 $(90-70 \mathrm{~cm})$, descritas a seguir:

SBU1 (34935- 9.685 anos cal. AP). Esta zona é caracterizada pela presença de elementos arbóreos, com destaque para Arecaceae, Asteraceae (Vernonia), Bredemeyera, Casearia, Cassia, Celtis, Croton, Guarea, Hedyosmum, Herissantia, Ilex, Lonchocarpus, Malpighiaceae, Maprounea, Melastomataceae, Myrtaceae, Podocarpus, Simaroubaceae, Symplocos, Tabebuia, Tetrorchidium, Tocoyena e Ziziphus. Esta categoria varia entre 5\% e $25 \%$ nesta zona, com concentrações entre 5.000 e 21.600 grãos $/ \mathrm{cm}^{3}$, que indicam a presença de vegetação florestal relativamente densa. O componente herbáceo é bem representado pelas terrestres Alternanthera (25\%), Amaranthus (10\%), Apocynaceae (8\%), Araceae, Asteraceae (11\%), Froelichia (10\%), Gomphrena (20\%), Poaceae (22\%) e Spermacoce (8\%). Já entre as aquáticas as mais representativas são Borreria (17\%) e Cyperaceae (11\%). 

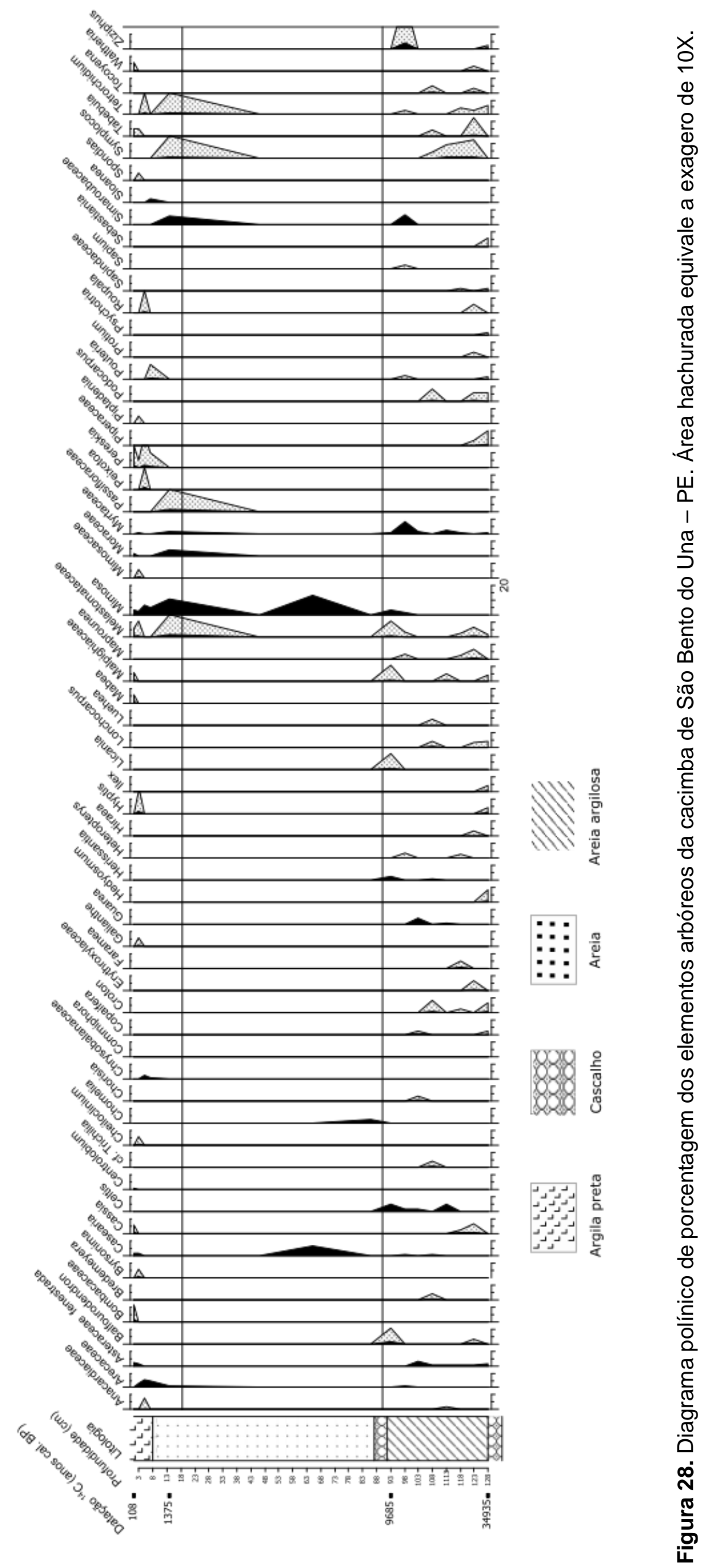


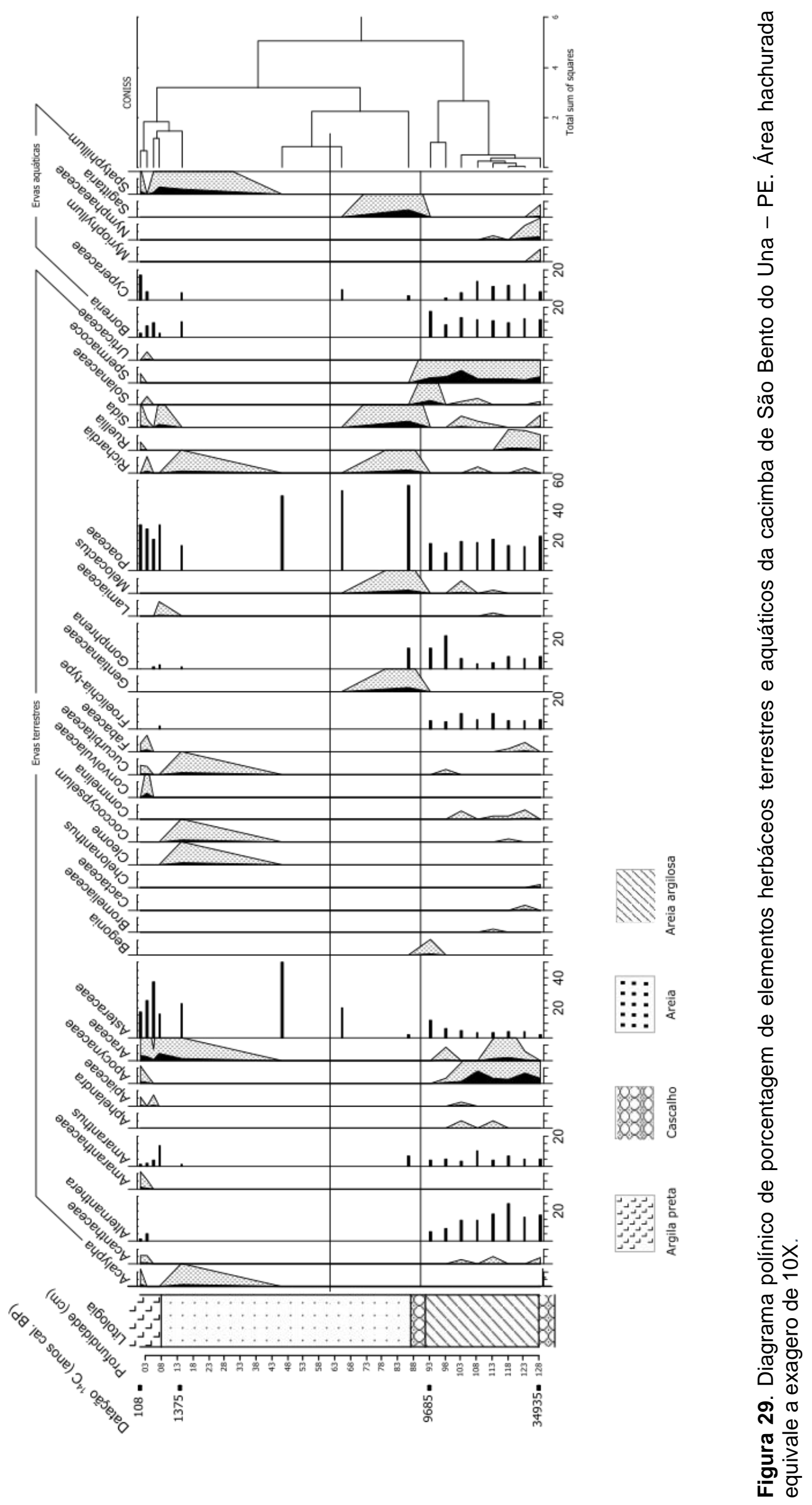


As ervas terrestres atingem 95.000 grãos $/ \mathrm{cm}^{3}$ e $76 \%$ da soma polínica, enquanto as ervas aquáticas chegam a 23.000 grãos $/ \mathrm{cm}^{3}$ e $23 \%$ da soma polínica. Ainda nesta ecozona ocorre a presença da criptógama aquática Azolla, que inicia a zona com 11.700 grãos $/ \mathrm{cm}^{3} \mathrm{e}$ atinge $16.600 \mathrm{grãos} / \mathrm{cm}^{3}$, enquanto as algas passam de 600 a 1.100 e de volta a 500 zigósporos $/ \mathrm{cm}^{3}$. As pteridófitas iniciam com 4.800 esporos $/ \mathrm{cm}^{3}$ e mantêm uma média de 2.000 esporos $/ \mathrm{cm}^{3}$. É notável também a presença de grãos danificados (8.200 a 16.600 e 440 grãos $\left./ \mathrm{cm}^{3}\right)$ e partículas carbonizadas maiores que $100 \mu \mathrm{m}\left(2.172\right.$ a 0 e $\left.1.487 / \mathrm{cm}^{3}\right)$.

SBU2 (9.685 a 1.375 anos cal. AP). Esta ecozona, apesar de possuir 70 $\mathrm{cm}$ de espessura, é composta por sedimentos arenosos e só foi possível obter três amostras para análises. $O$ espectro arbóreo é representado por Casearia, Chomelia e Mimosa, com concentrações de 20, 32 e $63 \mathrm{grãos} / \mathrm{cm}^{3}$ respectivamente. Entre as ervas terrestres foram recuperadas Amaranthus, Asteraceae, Gomphrena, Poaceae, Richardia e Sida, com a concentração mais elevada na primeira amostra da zona, que atingiu $805 \mathrm{grãos} / \mathrm{cm}^{3}$. O mesmo ocorreu entre as ervas aquáticas, representadas por Cyperaceae e Sagittaria com o acúmulo total de $60 \mathrm{grãos} / \mathrm{cm}^{3}$. Na mesma amostra Azolla atingiu 605 esporos $/ \mathrm{cm}^{3}$, as pteridófitas 584 esporos $/ \mathrm{cm}^{3}$, os danificados 443 grãos $/ \mathrm{cm}^{3} \mathrm{e}$ as partículas carbonizadas acima de $100 \mu \mathrm{m} 1.048 / \mathrm{cm}^{3}$.

SBU3 (1.375 a 108 anos cal. AP). Esta zona polínica se caracteriza pela baixa concentração generalizada de todas as categorias, quando comparada à zona SBU3. No entanto, em termos de porcentagem, os elementos arbóreos apresentam um leve aumento, passando de $15 \%$ no final daquela zona para 30\% no início desta, diminuindo novamente para a casa dos $15 \%$. Os táxons mais representativos são Arecaceae, com $5 \%$, Asteraceae (tipo Vernonia) com $2 \%$ no final da zona, Mimosa, que inicia a zona com 10\% e finaliza com 3\% e Simaroubaceae, que inicia com $6 \%$ e desaparece no final. Entre as ervas terrestres predominam Alternanthera, que inicia com $0 \%$, passa a $5 \%$ e finaliza com $1,7 \%$, Amaranthus, (1\% - 13\% - 1\%), Araceae com $1,5 \%$, depois $4,9 \%$ e por fim $3,4 \%$, Asteraceae com $22 \%$ no início, depois $24 \%$ e no fim $17 \%$ e Poaceae, (16\% - 30\% - 21\% - 30\%). Já nas ervas aquáticas, Borreria inicialmente com $10 \%$ cai para 2,8\%, Cyperaceae aumenta de $4,5 \%$ para $16 \%$ e Spatyphillum que inicia com $3 \%$, aumenta para $4,9 \%$ e cai para $1,7 \%$. Azolla diminui sua concentração drasticamente, passando de 5.700 esporos $/ \mathrm{cm}^{3}$ no final da zona 
SBU3 para 150 no início desta, atingindo o máximo de 1.500 esporos $/ \mathrm{cm}^{3}$ ao término da zona, assim como as algas, que também mantém concentrações baixas, com início em 150, aumento para 630 e posterior diminuição para 250 zigósporos $/ \mathrm{cm}^{3}$. As pteridófitas apresentam um aumento elevado em uma amostra determinada, atingindo 4.600 esporos $/ \mathrm{cm}^{3}$, ao mesmo tempo em que as partículas carbonizadas maiores que $100 \mu \mathrm{m}$ atingem $4.453 / \mathrm{cm}^{3}$ e os grãos danificados sobem para $5.400 / \mathrm{cm}^{3}$.

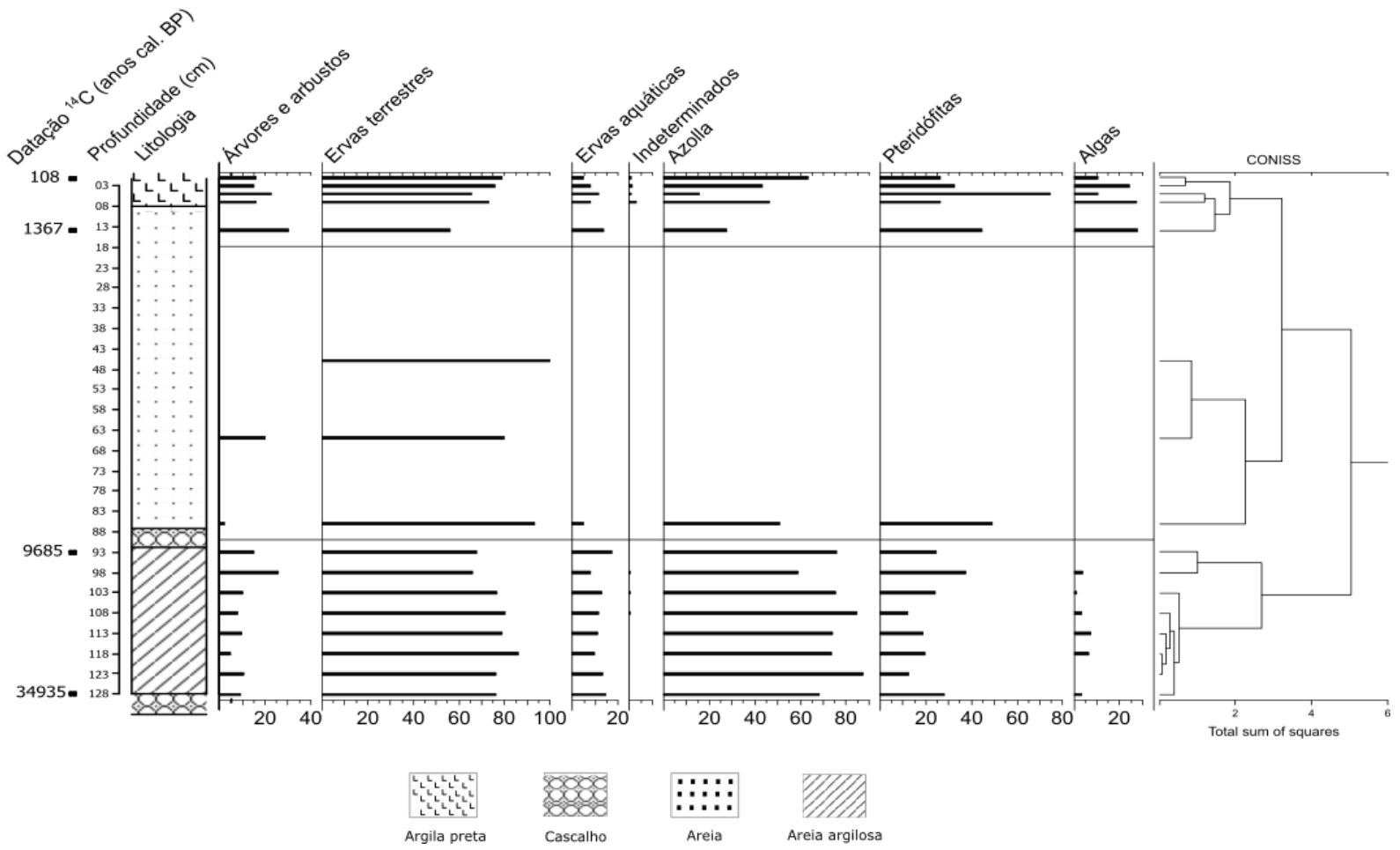

Figura 30. Diagrama polínico de porcentagem de categorias da cacimba de São Bento do Una - PE.

\subsubsection{Isótopos de Carbono e Nitrogênio}

A análise de isótopos estáveis de Carbono e Nitrogênio obteve os resultados apresentados na figura 32 . 


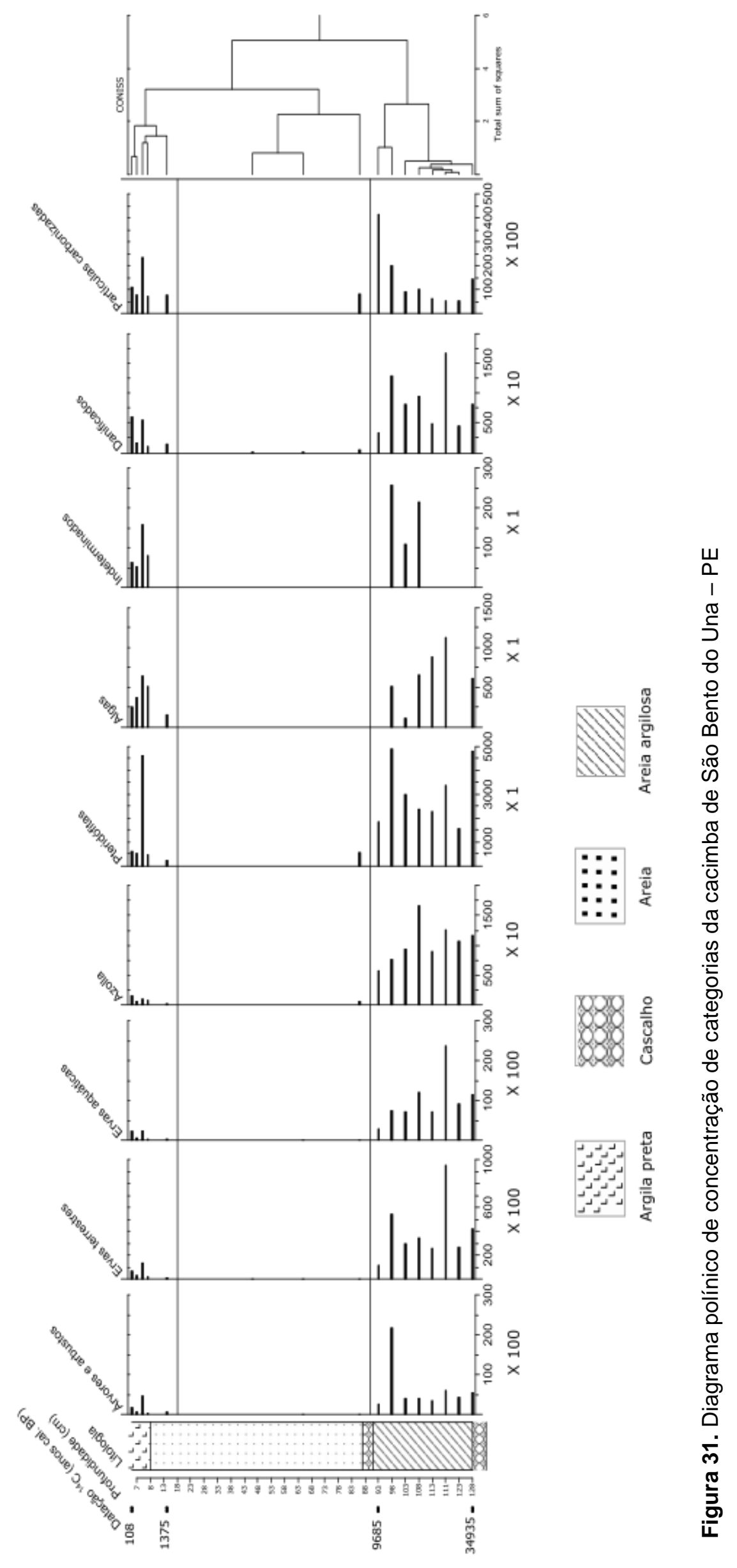




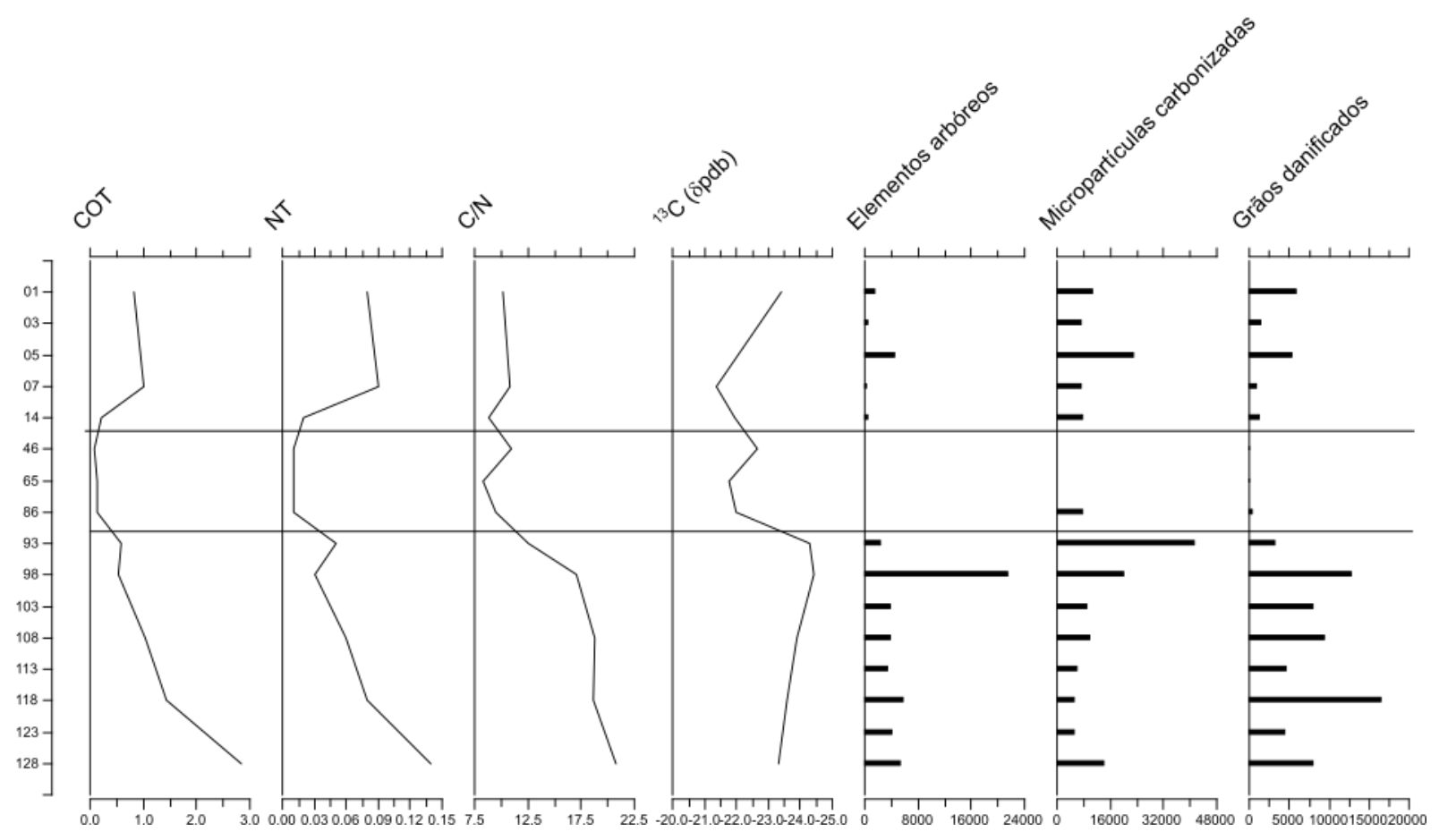

Figura 32. Distribuição de valores de COT, NT, C/N, $\delta 13 \mathrm{C}$, concentração de elementos arbóreos, micropartículas carbonizadas e grãos de pólen danificados, ao longo do perfil sedimentar de São Bento do Una - PE.

Nota-se que a quantidade de Carbono Orgânico Total (COT) é baixa ao longo de todo o perfil, inicia a camada basal com $2,83 \%$, diminui a 0 e finaliza com $1 \%$, assim como o Nitrogênio Total (NT), que fica constantemente abaixo de 0,15\%. Os valores do $\delta^{13} \mathrm{C}$ variam entre -21 e -24 , que sinalizam uma vegetação com processamento fotossintético do tipo C3, que geralmente é um sinal arbóreo. Já a razão $\mathrm{C} / \mathrm{N}$, com variação entre 20,71 no início do perfil e diminuição a 8,31 , revela que na base do testemunho a vegetação era composta predominantemente por plantas vasculares terrestres, e que ao passar para a zona SBU2, a incidência maior era de plantas aquáticas, como algas. Percebe-se que os picos de $\delta^{13} \mathrm{C}$ ocorrem ao mesmo tempo que o pico de elementos arbóreos e de partículas carbonizadas.

\subsubsection{Fitólitos}

A análise de fitólitos permitiu a identificação de elementos arbóreos, palmeiras, gramíneas, ervas terrestres, Bambusoides e Cyperaceae (Figura 33). A assembleia foi dominada por gramíneas (48\% a 76\%), com predominância das Panicóides, que variaram entre $18 \%$ e $37 \%$ ao longo do perfil, seguidas pelos elementos da Tribo 
Bambusoideae, cuja alternância esteve entre $11 \%$ e $32 \%$. Os elementos arbóreos, incluindo árvores e palmeiras oscilaram entre 5\% e 22\%.

\subsubsection{Diatomáceas}

A análise quantitativa deste microfóssil foi inviabilizada, devido à quantidade reduzida de frústulas por lâmina (>30), no entanto foram identificados vários gêneros e/ou espécies: Achnanthes deflexa, Cycoltella sp, Craticula cuspidata, Eunotia sp, Gomphonema sp, Luticola mutica, Pinnularia sp, Rhopalodia sp, assim como foram encontradas várias frústulas quebradas e dissolvidas (Anexo 2). Espículas de esponja também foram encontradas nas lâminas examinadas (Anexo 3). 

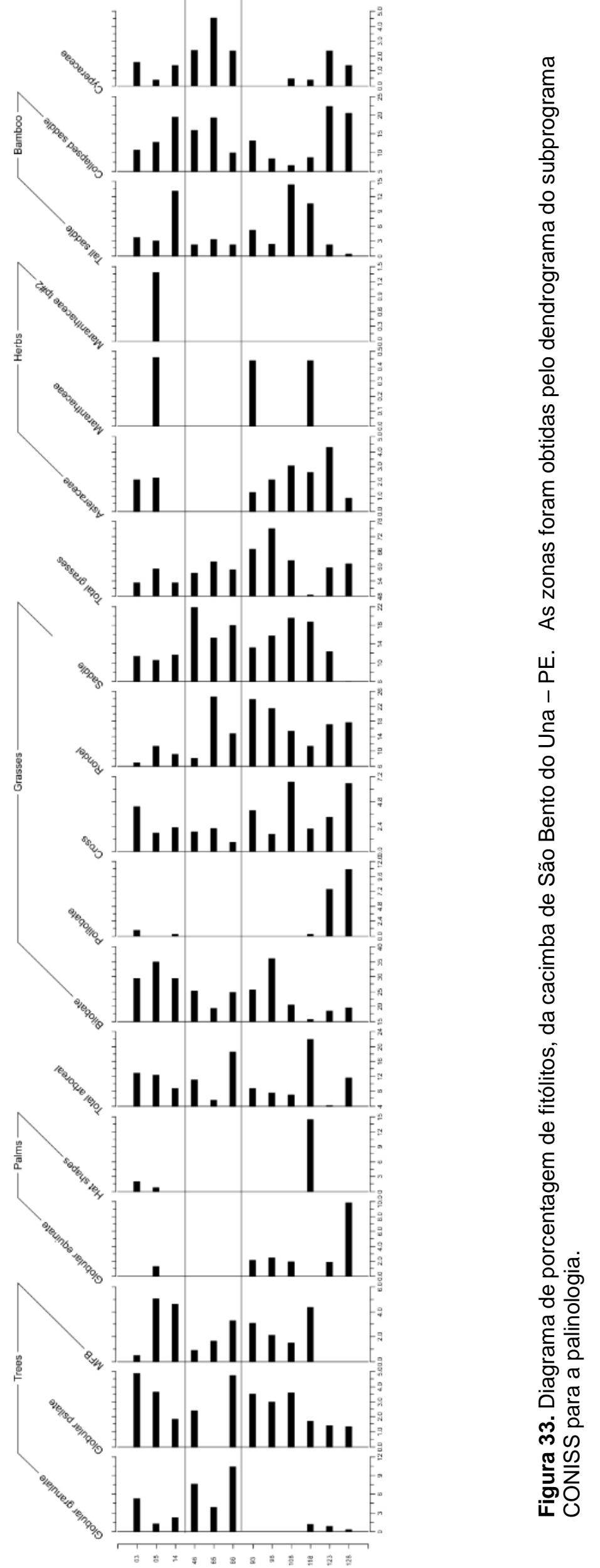


\section{SÃO JOÃO DO CARIRI - PB}

\section{1. Área de estudo}

10.1.1. Caracterização geográfica, geomorfológica e geológica

O município se localiza nas coordenadas 07²3'27"S e 36³1'58”W, com 458m de altitude e área de $700,6 \mathrm{~km}^{2}$. Está inserido na unidade geoambiental do Planalto da Borborema, que apresenta maciços e vales, por onde passam rios perenes, de baixa vazão, as altitudes na região variam de 650 a 1000 m (Mascarenhas et al., 2005b).

10.1.2. Caracterização climática e vegetacional

O clima no município é caracterizado como semiárido, do tipo BSh de Köppen. A média pluviométrica anual é de $399 \mathrm{~mm}$ e a de temperatura é de $23,2^{\circ} \mathrm{C}$. O trimestre mais chuvoso vai de fevereiro a abril, com a média de $102 \mathrm{~mm}$ em março, já o trimestre mais seco vai de setembro a novembro, com média de $2 \mathrm{~mm}$ em setembro (ClimateData, 2018). A vegetação se caracteriza como Caatinga arbórea, arbustiva e subarbustiva, com predominância de espécies pertencentes aos gêneros Caesalpinia, Aspidosperma, Pilosocereus, Croton e Jatropha, além da exótica Prosopis (Teles et al., 2006).

\subsection{Trabalho de campo}

Neste município foram coletados sedimentos em uma lagoa efêmera, que estava seca, preenchida por sedimentos orgânicos, escuros, localizada nas coordenadas $7^{\circ} 22^{\prime} 24.721^{\prime \prime S}$ e 36³1'40.327"O, na Bacia Escola da Universidade Federal da Paraíba. A coleta de sedimentos foi realizada em trincheira escavada com $1,50 \times 1,50 \mathrm{~m}$ de largura e $170 \mathrm{~cm}$ de profundidade, os quais foram descritos e amostrados in situ, com intervalos de $5 \mathrm{~cm}$ (Figura 34).

\subsection{Resultados}

10.3.1. Litologia e datação

O perfil amostrado na Bacia Escola apresentou $170 \mathrm{~cm}$ de sedimentos compostos por argila arenosa marrom e idades radiocarbônicas entre 6216 e 1615 anos cal. AP (Tabela 5), e modelo de idade (Figura 35), obtido através do pacote 
Rbacon (Blaauw e Christen, 2011), com probabilidade de 95\% e curva SHCAL13 (Hogg et al., 2013).

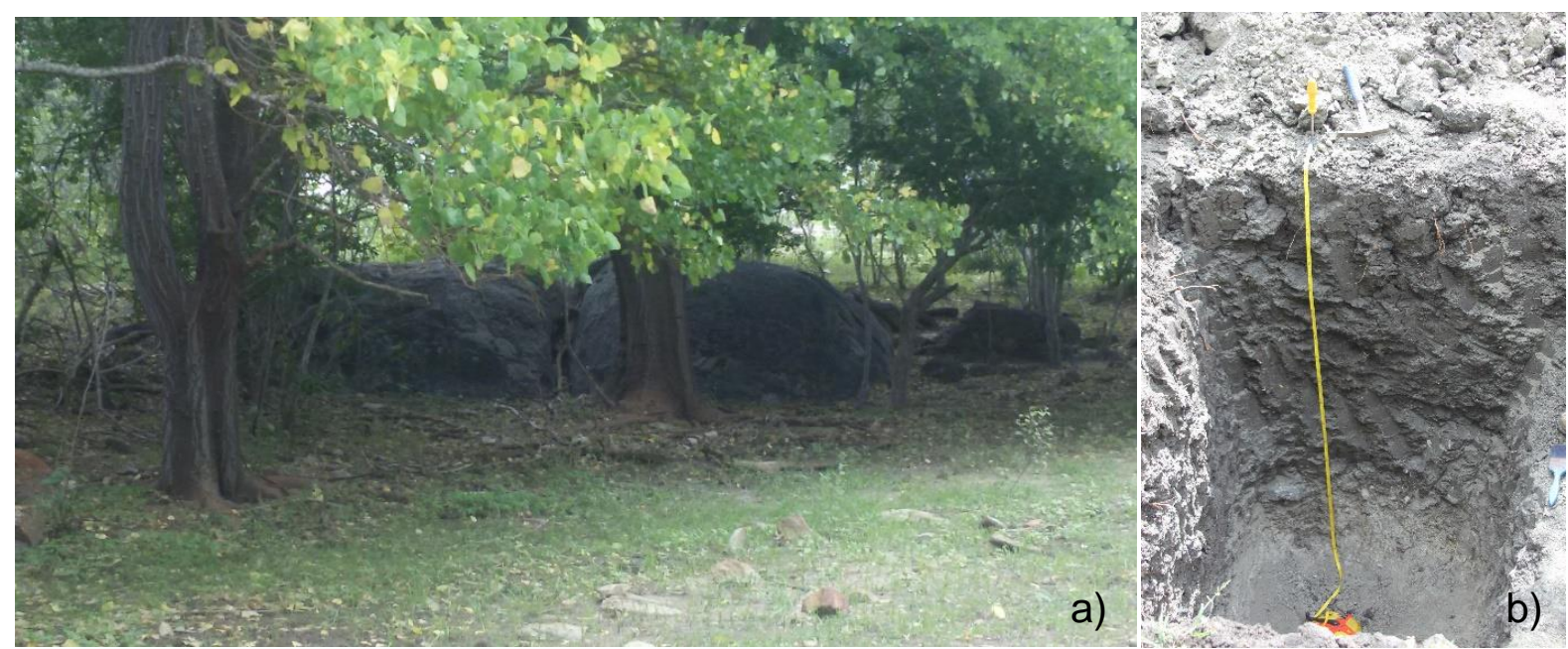

Figura 34. Perfil coletado em São João do Cariri - PB. a) Local de coleta, circulado com matacões; b) Trincheira escavada para amostragem. Fotos: Vanda B. de Medeiros.

Tabela 5. Idades radiocarbônicas de sedimentos coletados em São João do Cariri - PB

\begin{tabular}{clcc}
\hline Amostra & Nr. Laboratório & Idade 14C & Idade Calibrada (anos cal. AP) \\
\hline 55 & BETA 513367 & $1770 \pm 30$ & 1615 \\
115 & BETA 513368 & $2660 \pm 30$ & 2789 \\
170 & BETA 462506 & $5600 \pm 30$ & 6216 \\
\hline
\end{tabular}

\subsubsection{Palinologia}

A figura 36 mostra a porcentagem de elementos arbóreos, a figura 37 apresenta as porcentagens das ervas terrestres e aquáticas. A figura 38 mostra a porcentagem criptógamas aquáticas, pteridófitas e algas, enquanto as figuras 39 e 40 mostram as porcentagens e concentrações, respectivamente das categorias arbóreas, ervas terrestres e aquáticas, pteridófitas, algas, grãos danificados e palinomorfos não identificados, além da litologia, palinozonas e dendrograma CONISS. 


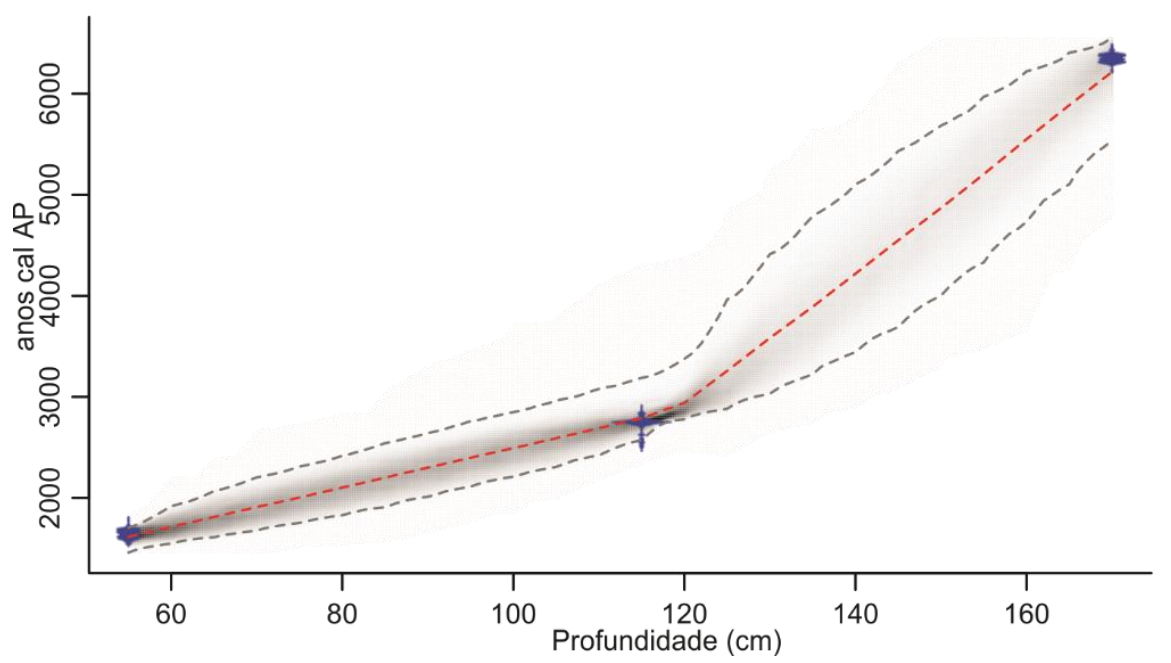

Figura 35. Modelo de idade calibrado construído com pacote Rbacon (Blaauw e Christen, 2011), para o testemunho de São João do Cariri - PB.

Através do dendrograma construído pelo subprograma CONISS foram demarcadas três zonas polínicas: BES A (170 a $115 \mathrm{~cm})$, BES B (115 a $55 \mathrm{~cm}$ ) e BES C $(55$ a $0 \mathrm{~cm})$, descritas a seguir:

BES A (6.216 anos cal. AP a 2.789 anos cal. AP - 170 a $115 \mathrm{~cm}$ ): Esta zona é dominada por ervas terrestres, que se iniciam com $65 \%$, atingem $82 \%$ e finalizam com $71 \%$, com pico de 2.700 grãos $/ \mathrm{cm}^{3}$, enquanto os elementos arbóreos não passam de $20 \%$ e 1.013 grãos $/ \mathrm{cm}^{3}$, ao mesmo tempo em que as ervas aquáticas atingem 1.135 grãos $/ \mathrm{cm}^{3}$ e $23 \%$ da soma polínica. A concentração de micropartículas carbonizadas atinge o total de $20.500 / \mathrm{cm}^{3}$ e os grãos danificados chegam a $2.500 / \mathrm{cm}^{3}$. Quando somados aos demais grãos de pólen, a porcentagem destes varia entre $40 \%$ e $60 \%$ do total. Os elementos arbóreos mais representativos são Casearia, Chomelia, Mimosa, Moraceae, Myracrodruon e Piptadenia, entretanto, entre estes, o táxon que atingiu maior representatividade foi Mimosa, com 6,5\%. Entre as ervas terrestres ocorreu o predomínio de Araceae e Poaceae, ambas com picos em volta de $40 \%$. As ervas aquáticas são representadas por Azolla, que inicia com 0,8\%, atinge 4,6\% e diminui para $1 \%$; Cyperaceae inicia com $15 \%$, diminui para $2 \%$ e volta a subir gradativamente até atingir $12 \%$ e Spathiphyllum que começa com $0 \%$ e termina a zona com $1 \%$. Entre as algas se destacam Brotryococcus, com 622 zigósporos $/ \mathrm{cm}^{3} \mathrm{e}$ Zygnema, com pico de 1.150 zigósporos $/ \mathrm{cm}^{3}$. 


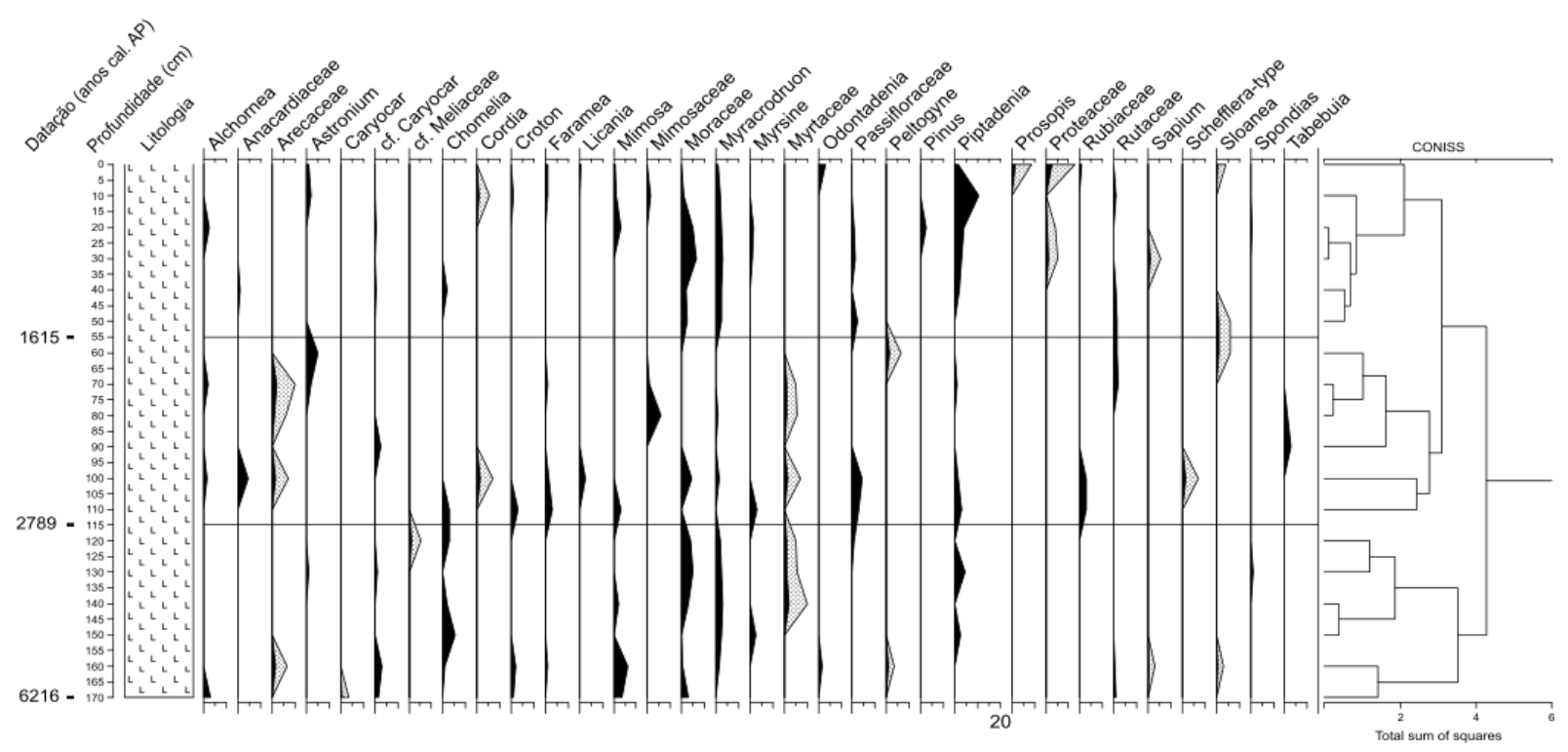

Argila arenosa marrom

Figura 36. Diagrama polínico de elementos arbóreos, do testemunho de São João do Cariri - PB. Área hachurada com exagero de $5 \mathrm{X}$.

BES B (2.789 anos cal. AP a 1.615 anos cal. AP - 115 a $55 \mathrm{~cm})$ : Esta zona, assim como a anterior, é dominada por ervas terrestres, que iniciam com $75 \%$ diminuem para $57 \%$, aumentam para $92 \%$ e finalizam a zona com $79 \%$, com pico de 4000 grãos $/ \mathrm{cm}^{3}$. Os elementos arbóreos oscilam ao longo da zona, com pico de $30 \%$ no início da zona e mínimo de $5 \%$ e 735 e 96 grãos $/ \mathrm{cm}^{3}$, enquanto as ervas aquáticas iniciam a zona sem representação e oscilam entre $12 \%$ e $2 \%$ e 487 e 0 grãos $/ \mathrm{cm}^{3}$. Entre os palinomorfos ocorre a dominância de algas, que começam com 96\% e finalizam com $70 \%$ e oscilam entre 480 e 2221 zigósporos $/ \mathrm{cm}^{3}$. As micropartículas de carvão iniciam a zona com $41785 / \mathrm{cm}^{3}$, diminuem para $7831 / \mathrm{cm}^{3}$ e finalizam a zona com $38772 / \mathrm{cm}^{3}$. Grãos danificados aparecem inicialmente nesta zona com $2186 / \mathrm{cm}^{3}$ e finalizam com $3086 / \mathrm{cm}^{3}$. Entre os elementos arbóreos, os de mais representativos foram Alchornea, Anacardiaceae, Astronium, Mimosoide, Moraceae, Passifloraceae, Piptadenia, Rubiaceae e Tabebuia. Entre as ervas terrestres sobressaem Araceae, Asteraceae e Poaceae, enquanto nas ervas aquáticas o predomínio é de Cyperaceae. A alga com maior predominância é Zygnema.

BES C (1.615 anos cal. AP ao atual - 55 a $0 \mathrm{~cm})$ : Nesta zona, como nas anteriores, o predomínio é das ervas terrestres, apesar de ser observado um pequeno declínio nas suas porcentagens, uma vez que iniciam com $75 \%$, passam a $69 \%$ e 
finalizam a zona com nova elevação, na casa de $85 \%$. Já nos elementos arbóreos se percebe um aumento seguido de nova diminuição, com $9 \%, 24 \%$ e depois $15 \%$. As algas se mantêm constantes, na casa dos $85 \%$. Em termos de concentração há uma tendência geral de elevação, as ervas terrestres atingem 4997 grãos $/ \mathrm{cm}^{3}$, os elementos arbóreos alcançam seu maior índice, com $1639 \mathrm{grãos} / \mathrm{cm}^{3}$, apesar de acabar a zona com $738 \mathrm{grãos} / \mathrm{cm}^{3}$. As algas atingem 2732 zigósporos $/ \mathrm{cm}^{3}$ e as micropartículas de carvão chegam a $35293 / \mathrm{cm}^{3}$ e finalizam com $13170 / \mathrm{cm}^{3}$. Os grãos danificados iniciam a zona com $2905 / \mathrm{cm}^{3}$, aumentam para $5778 / \mathrm{cm}^{3}$ e finalizam com $3816 / \mathrm{cm}^{3}$. Os elementos arbóreos mais abundantes são Alchornea, Astronium, Mimosa, Moraceae, Myracrodruon, Odontadenia e Piptadenia. Pinus e Prosopis aparecem no registro sedimentar pela primeira vez. As ervas terrestres são representadas predominantemente por Araceae, Asteraceae e Poaceae, enquanto as aquáticas são dominadas por Cyperaceae. Entre as algas sobressaem Botryococcus e Zygnema.

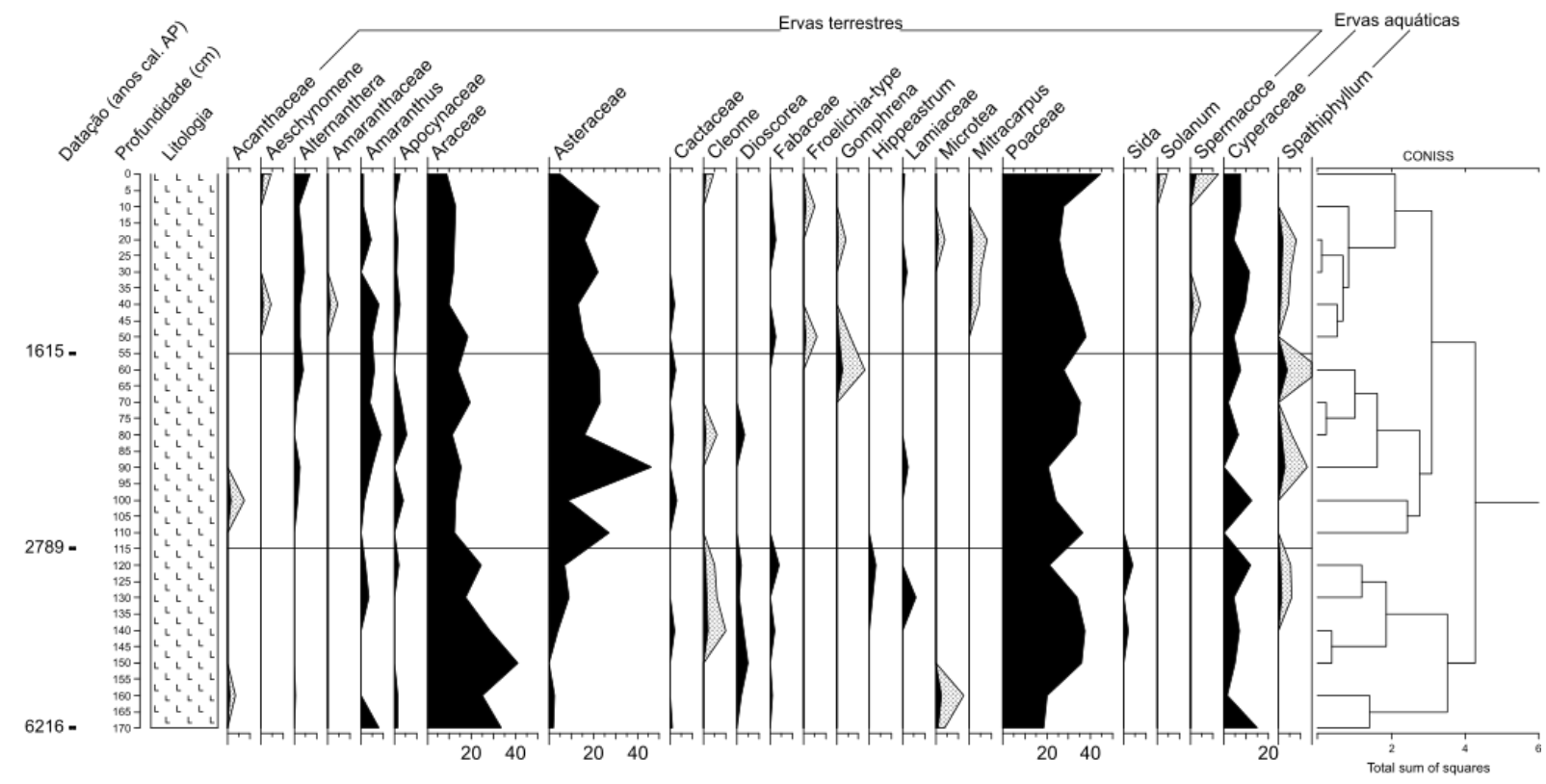

Argila arenosa marrom

Figura 37. Diagrama polínico de porcentagem de ervas terrestres e aquáticas, do testemunho de São João do Cariri - PB. Área hachurada com exagero de 5X.

10.3.3. Isótopos de Carbono e Nitrogênio

A análise de isótopos estáveis de Carbono e Nitrogênio, realizada no CENA/USP, obteve os resultados apresentados na figura 41. 
Nota-se que a quantidade de Carbono Orgânico Total (COT) é baixa ao longo de todo o perfil e não passa de $0,5 \%$, assim como o Nitrogênio Total (NT), que fica constantemente abaixo de $0,05 \%$. Os valores do $\delta^{13} \mathrm{C}$ variam entre -20 e -23 , que sinalizam uma vegetação com processamento fotossintético do tipo C3. Já a razão $\mathrm{C} / \mathrm{N}$, com variação entre 10 e 8,7, indicam que a matéria orgânica é proveniente de plantas aquáticas e/ou algas.

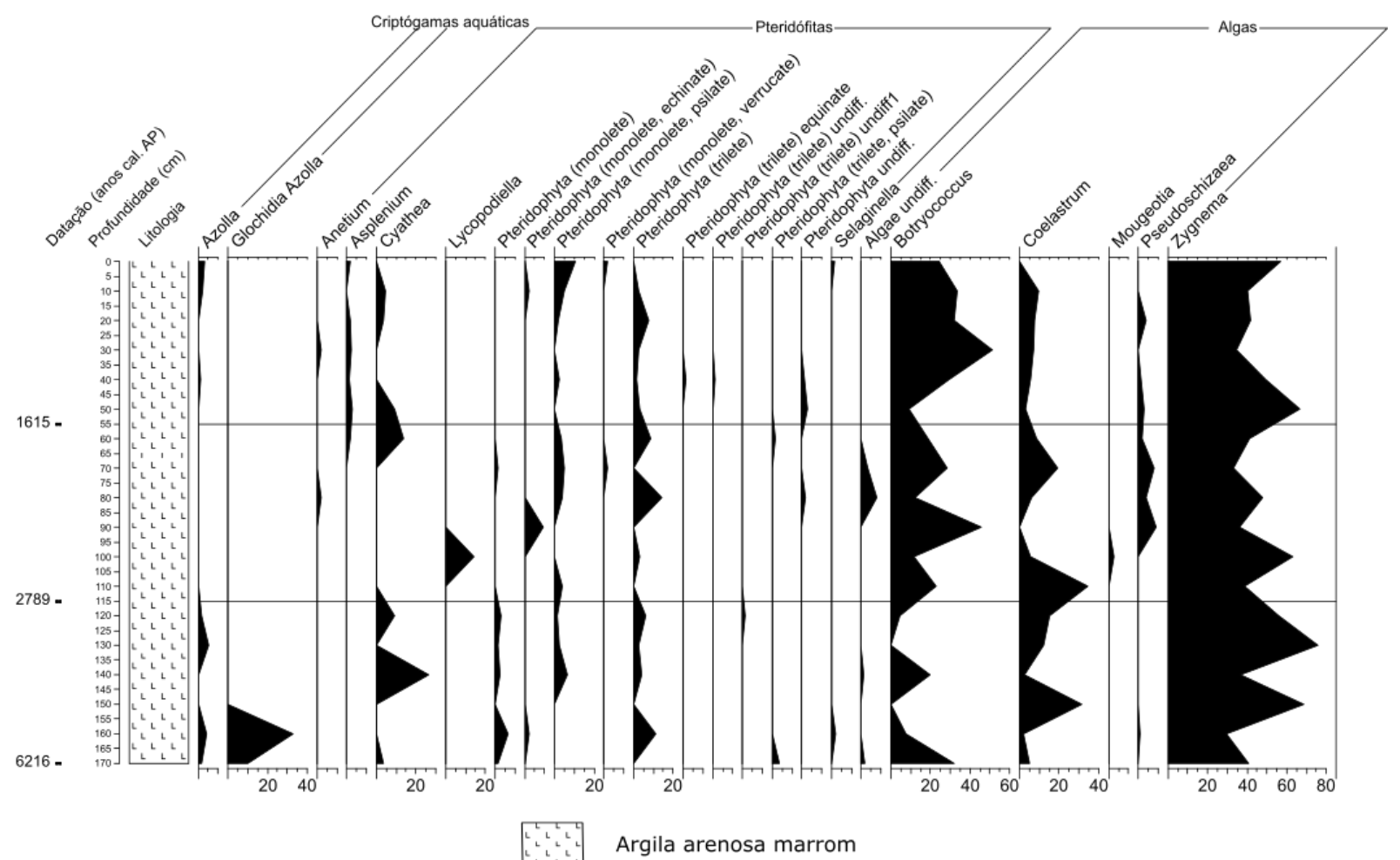

Figura 38. Diagrama polínico de porcentagem de criptógamas aquáticas, pteridófitas e algas do testemunho de São João do Cariri - PB.

\subsubsection{Diatomáceas}

A análise de diatomáceas nesta localidade ocorreu de forma diferenciada da convencional, uma vez que não havia frústulas suficientes para se realizar uma análise quantitativa, pois as tentativas de contagem não atingiam 50 frústulas de diatomácias em duas lâminas. No entanto, foi possível a identificação de cinco delas, a nível de gênero e uma a nível de espécie: Stauroneis sp, Pinnularia sp, Synedra sp, Navicula sp, Rhopalodia sp e Craticula cuspidata e, além disso, muitas estavam dissolvidas ou quebradas (Anexo 2). 

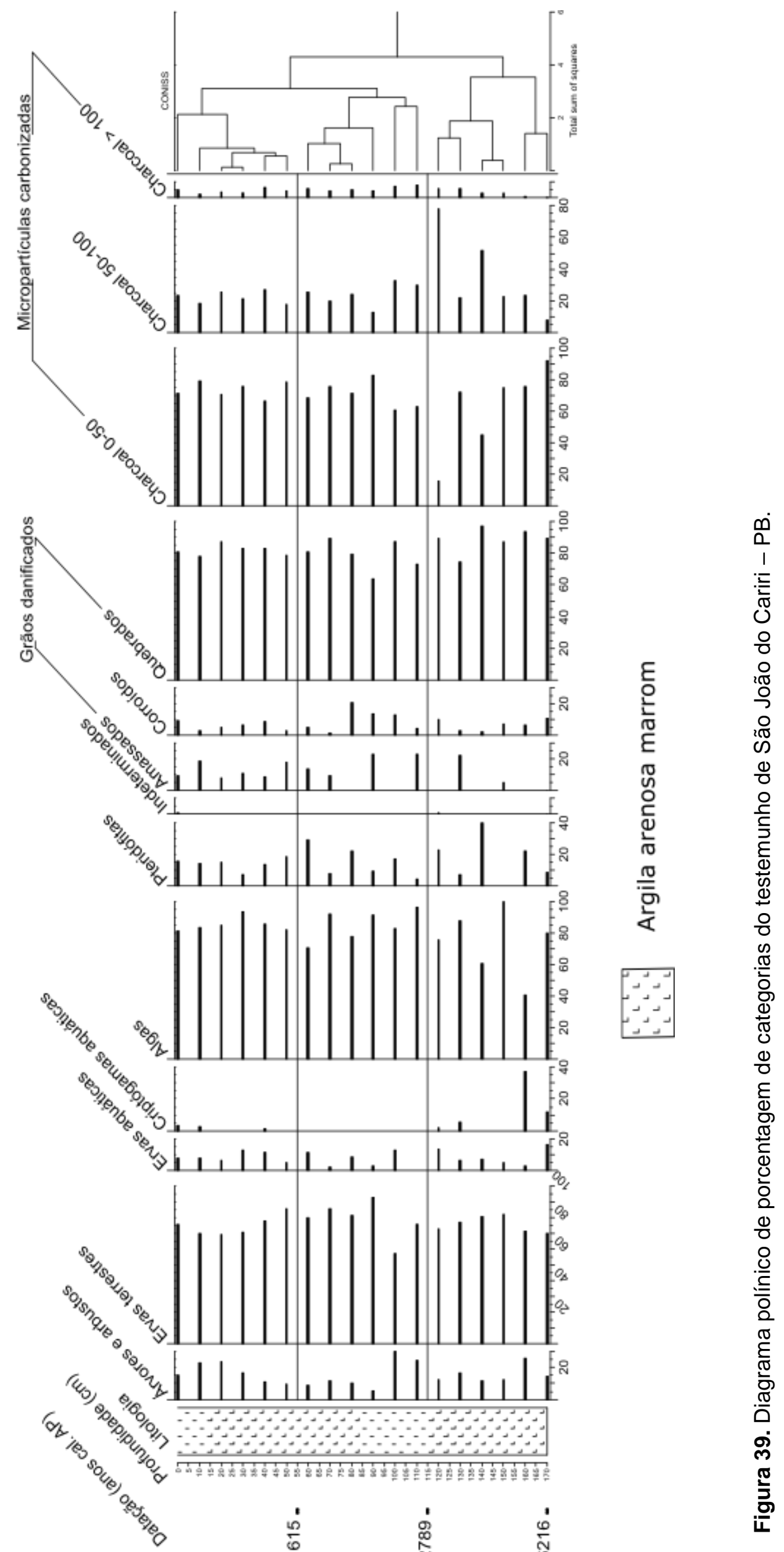


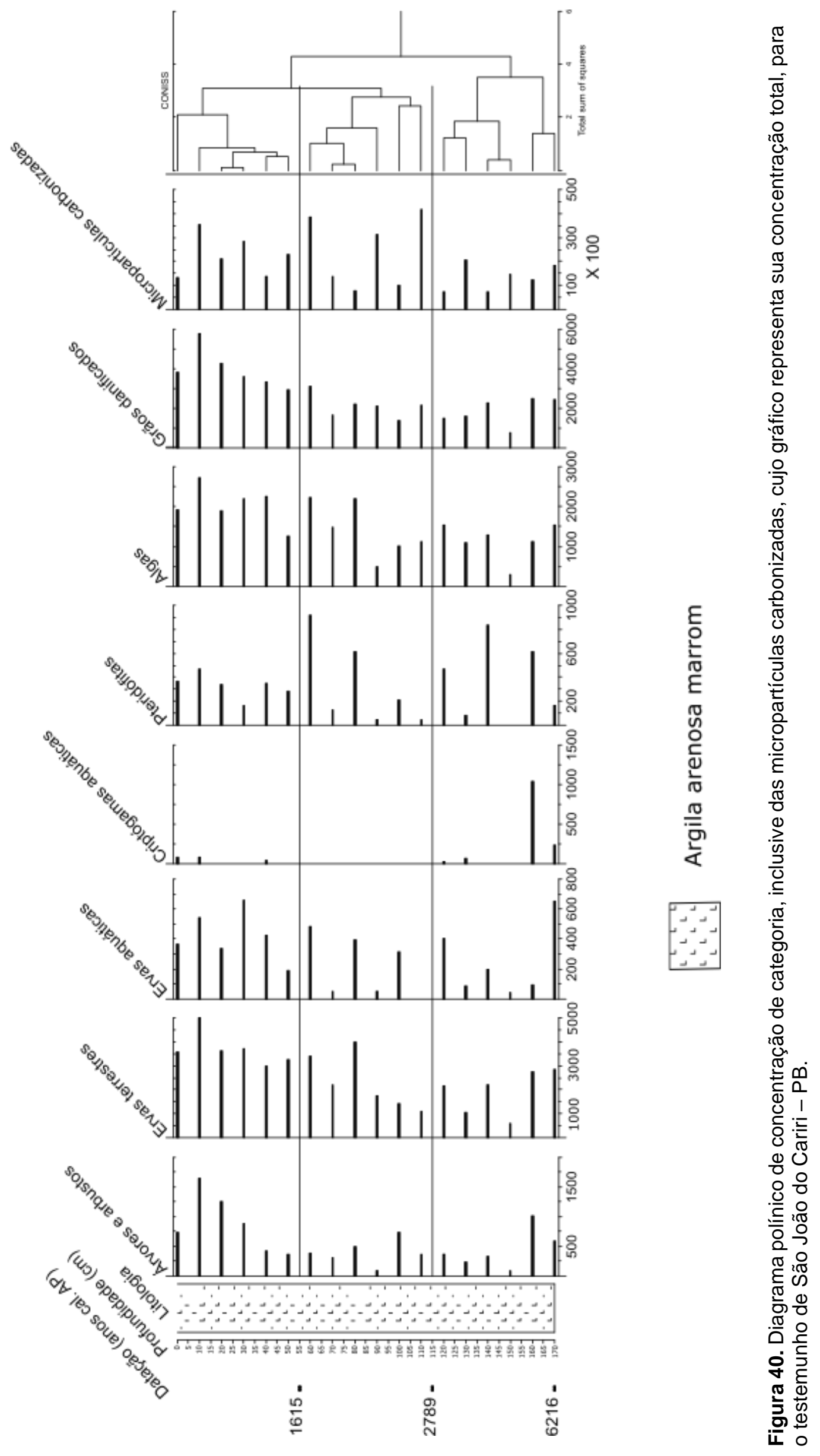




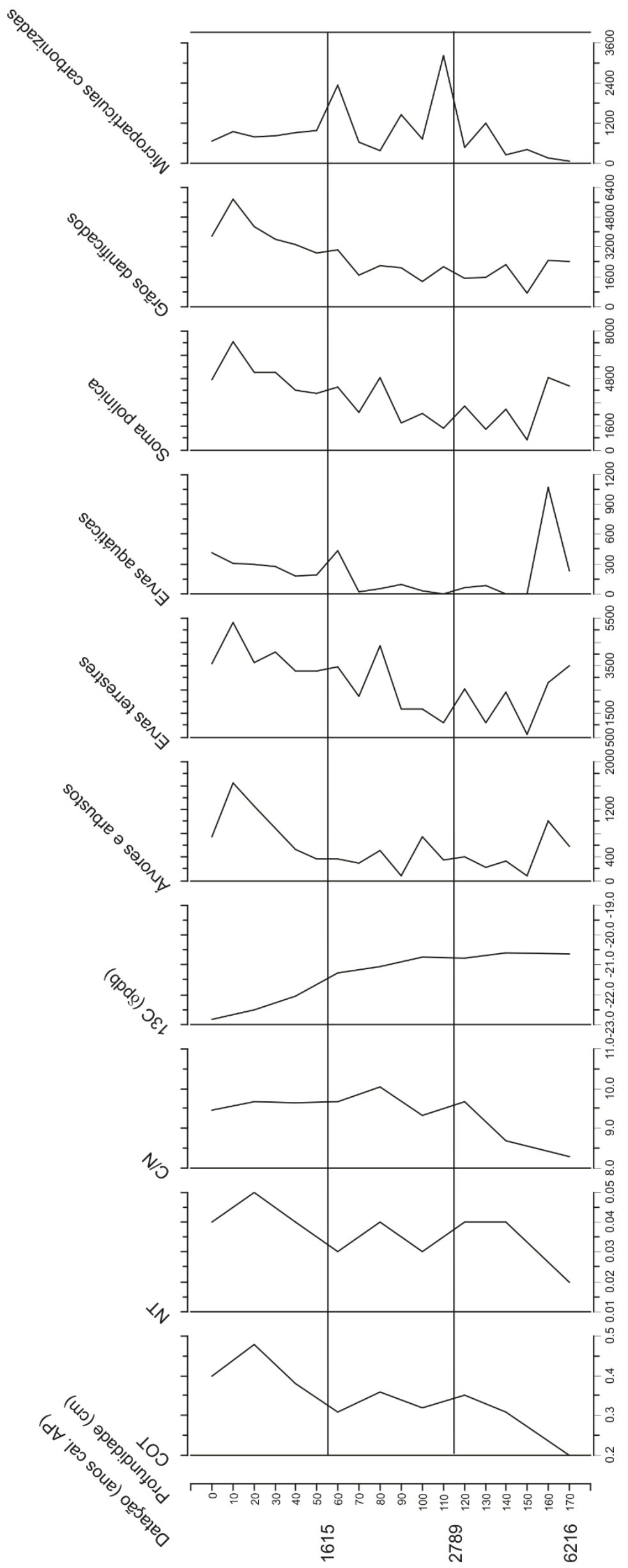

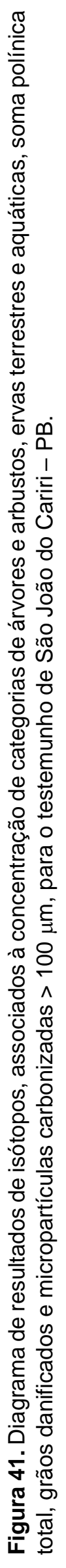

73 


\section{AFRÂNIO - PE}

\section{1. Área de estudo}

11.1.1. Caracterização geográfica, geomorfológica e geológica

O município de Afrânio está situado nas coordenadas 8³0'54"S e 4100"8”W, com altitude de 522 m em média e área de 1482 km2, está inserido na Depressão Sertaneja, com relevo suave e vales estreitos e se encontra na Bacia Hidrográfica do Rio do Pontal, o qual é intermitente. O município apresenta estruturação geológica complexa, com litotipos provenientes do Paleoproterozóico, Mesoproterozóico, Neoproterozóico e do Cenozóico (Mascarenhas et al., 2005a).

\subsubsection{Caracterização climática e vegetacional}

O município está situado em região com clima semiárido, do tipo BSh da classificação de Köppen. O trimestre mais chuvoso vai de fevereiro a abril, com média anual de $556 \mathrm{~mm}$ e em abril a média é de $134 \mathrm{~mm}$. O trimestre mais seco vai de julho a setembro, com a média de $8 \mathrm{~mm}$ no período - em agosto a média é de $1 \mathrm{~mm}$. A temperatura média anual é de $24,7^{\circ} \mathrm{C}$ (Mascarenhas et al., 2005a). A vegetação é caracterizada por Caatinga hiperxerófila, arbustiva e arbustivo-arbóreo, com predominância de espécies pertencentes aos gêneros Cereus, Pilocereus, Zizyphus joazeiro, Hymenachne, Opuntia, Aspidosperma e Cnidoscolus, além da introduzida Prosopis (Silva, 2009), popularmente conhecida como Algaroba.

\subsection{Trabalho de campo}

Durante a viagem de prospecção realizada para esta localidade, em março de 2016, tentou-se fazer a coleta de sedimentos com o amostrador Livingstone (Colinvaux et al., 1999), uma vez que a Lagoa Comprida estava com quase dois metros de água (Figura 42), no entanto, a superfície dos sedimentos estava impenetrável e a coleta com este equipamento se tornou inviável. A segunda viagem de campo, em setembro de 2017, após um ano e meio encontrou a lagoa completamente seca e foi possível escavar uma trincheira de 3,50 X1,70 m e com $260 \mathrm{~cm}$ de profundidade. Após a descrição dos sedimentos, foram coletadas amostras in situ, da base para o topo, a cada $5 \mathrm{~cm}$ (Figura 43). A insistência nesta coleta ocorreu devido à análise anterior destes sedimentos, realizada por pesquisadores da UFPE, 
determinarem idade LOE de 11.700 anos AP à profundidade de $140 \mathrm{~cm}$ e a existência de ossadas de megafauna.

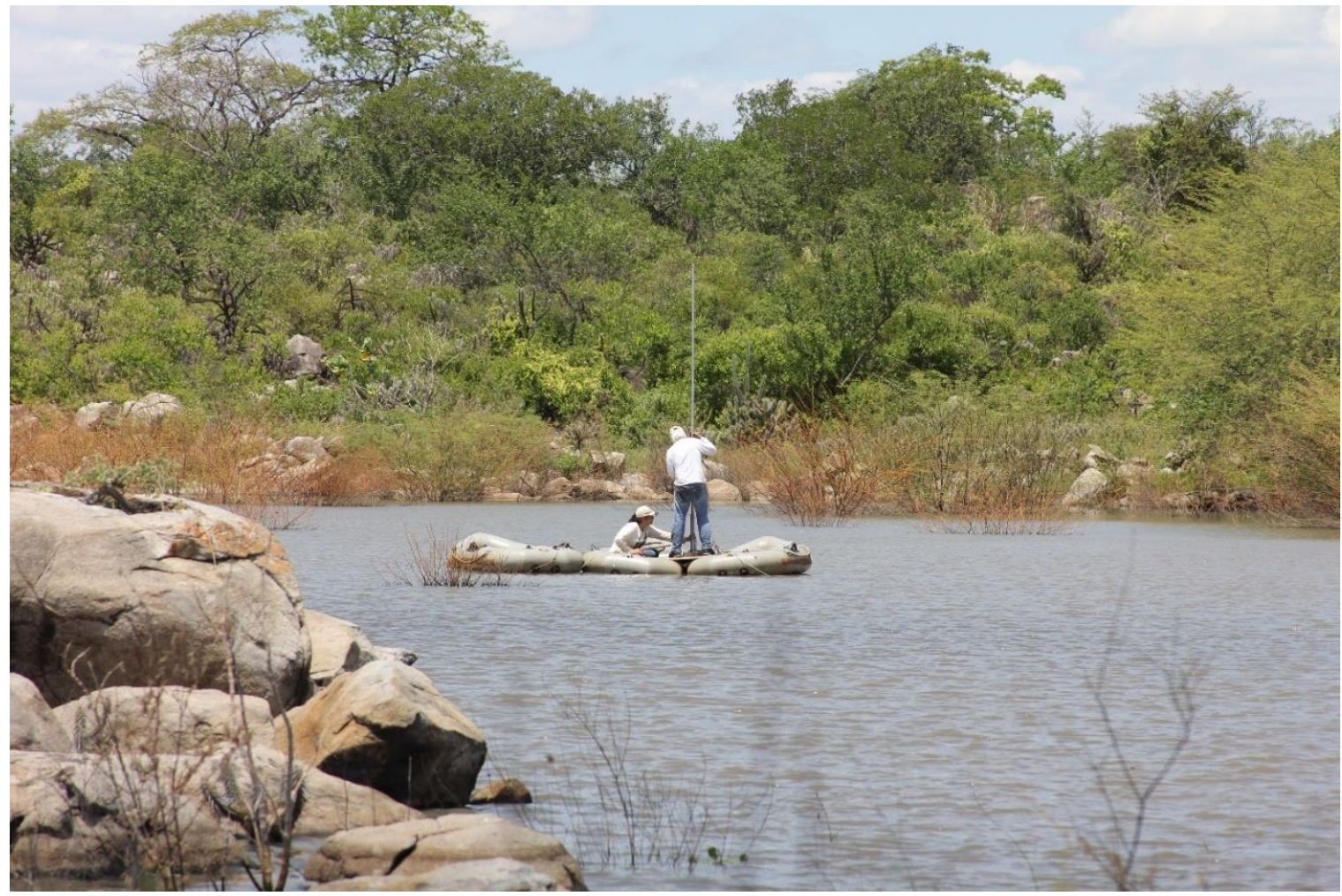

Figura 42. Tentativa de coleta de sedimentos lacustres com amostrador Livingstone realizada em março de 2016, em coluna d'água de 1,80 m, na Lagoa Comprida, em Afrânio - PE. Foto: Alcina F. Barreto

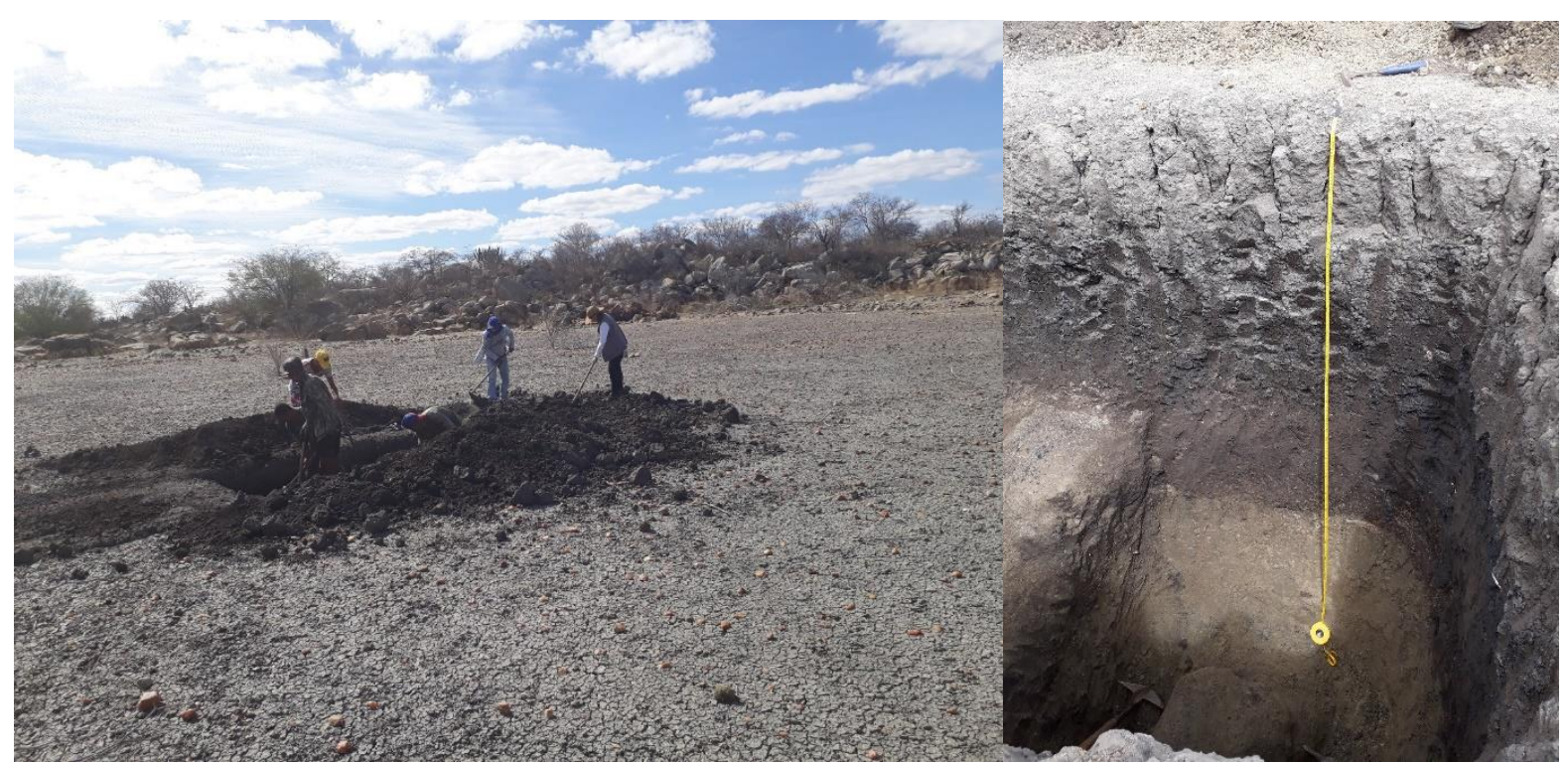

Figura 43. Trincheira escavada em Afrânio - PE. a) Panomorama geral da lagoa seca, com a trincheira escavada no centro; b) Vista frontal da trincheira, com $260 \mathrm{~cm}$ de profundidade, até o embasamento cristalino. Fotos: Vanda B. de Medeiros 


\subsection{Resultados}

11.3.1. Litologia e datação

A litologia do perfil amostrado, com um total de $260 \mathrm{~cm}$ de profundidade, está representada na figura 44 . Os primeiros $165 \mathrm{~cm}$ são compostos por argila preta, com intercalação de seixos de quartzo a $70 \mathrm{~cm}$. Em seguida, dos $165 \mathrm{~cm}$ a $177 \mathrm{~cm}$, há uma argila com laminações, que variam de preta a castanho. O primeiro fragmento de osso foi localizado em uma profundidade de $177 \mathrm{~cm}$, quando se inicia uma camada composta por $20 \mathrm{~cm}$ de silte arenoso, que passa por areia siltosa, com mosqueamento de cor cinza médio a esverdeado. Os últimos $30 \mathrm{~cm}$ são compostos por areia cascalhosa, de cor cinza esverdeada e finalmente ocorre uma camada de cascalhos de tamanhos variados. As idades obtidas para a camada de $30 \mathrm{~cm}$ e a base são de 765 anos cal. AP e 10.932 anos cal. AP, respectivamente (Tabela 6). Estas foram obtidas através do Software Bacon (Blaauw e Christen, 2011), com probabilidade de 95\% e curva SHCAL13 (Hogg et al., 2013). No entanto, durante o processamento da amostra de base, o laboratório Beta Analytic relatou a baixa quantidade de carbono, menor que $0,02 \%$, e a possibilidade da ocorrência de resultados alterados nesta amostra.

\subsubsection{Granulometria}

A análise granulométrica foi realizada no Laboratório de Sedimentologia do IGc/USP, com o método de granulometria por difração a laser, com a utilização do equipamento Malvern. Para a determinação do tamanho médio dos grãos, foram adotadas as curvas obtidas segundo o teste de significância $r$ de Pearson (Levin e Costa, 1987). Os resultados são apresentados na figura 45. 


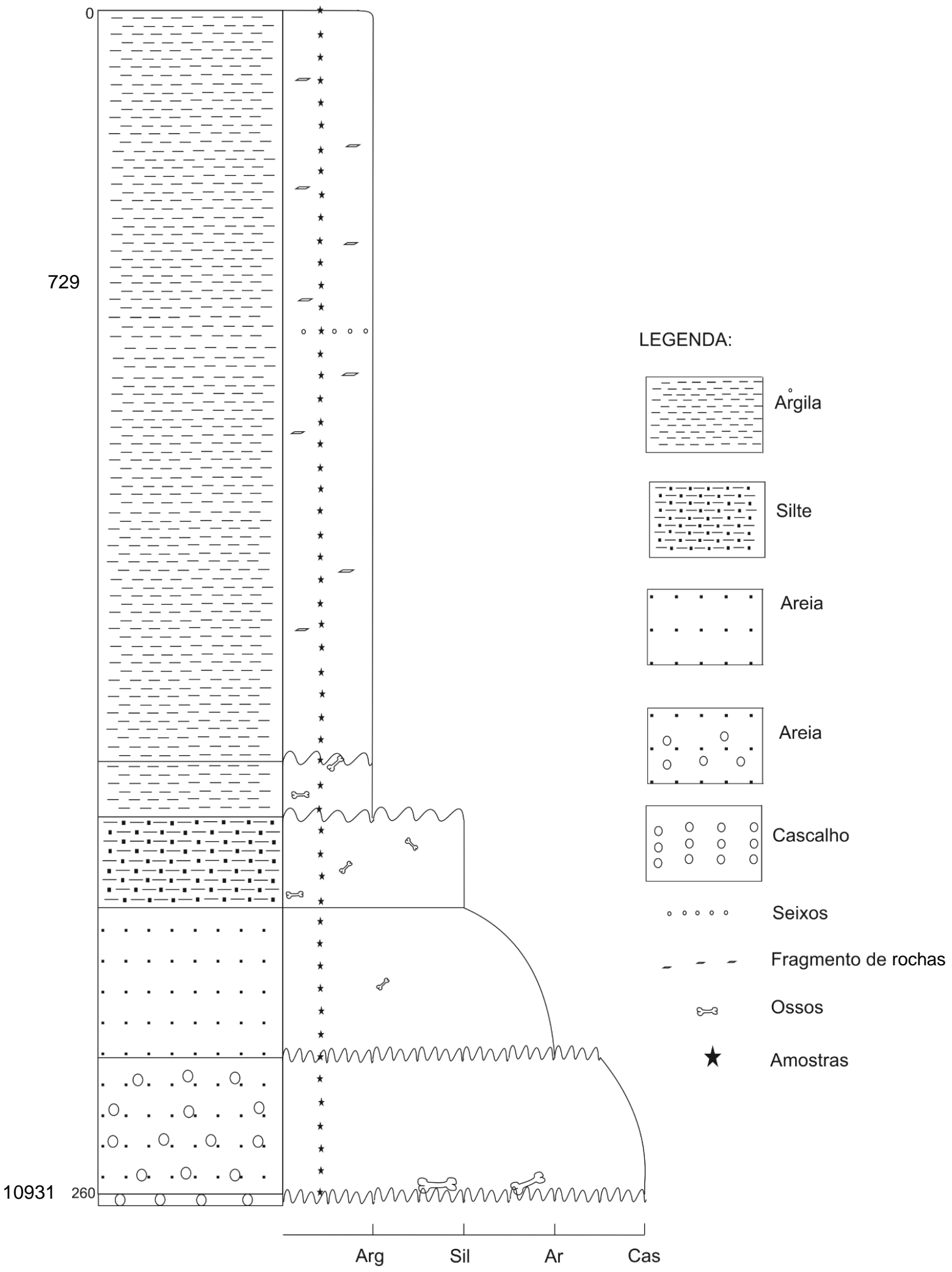

Figura 44. Seção estratigráfica do perfil escavado na Lagoa Comprida, em Afrânio - PE, com a sinalização de amostragem para as análises 
Tabela 6. Idades radiocarbônicas dos sedimentos coletados no município de Afrânio - PE

\begin{tabular}{|l|l|l|l|}
\hline Amostra & Nr. Lab. & Idade ${ }^{14} \mathrm{C}$ & Idade calibrada (anos cal. AP) $2 \sigma$ \\
\hline 30 & 509062 & $860 \pm 30$ & 729 \\
\hline 260 & 509063 & $9610 \pm 30$ & 10931 \\
\hline
\end{tabular}

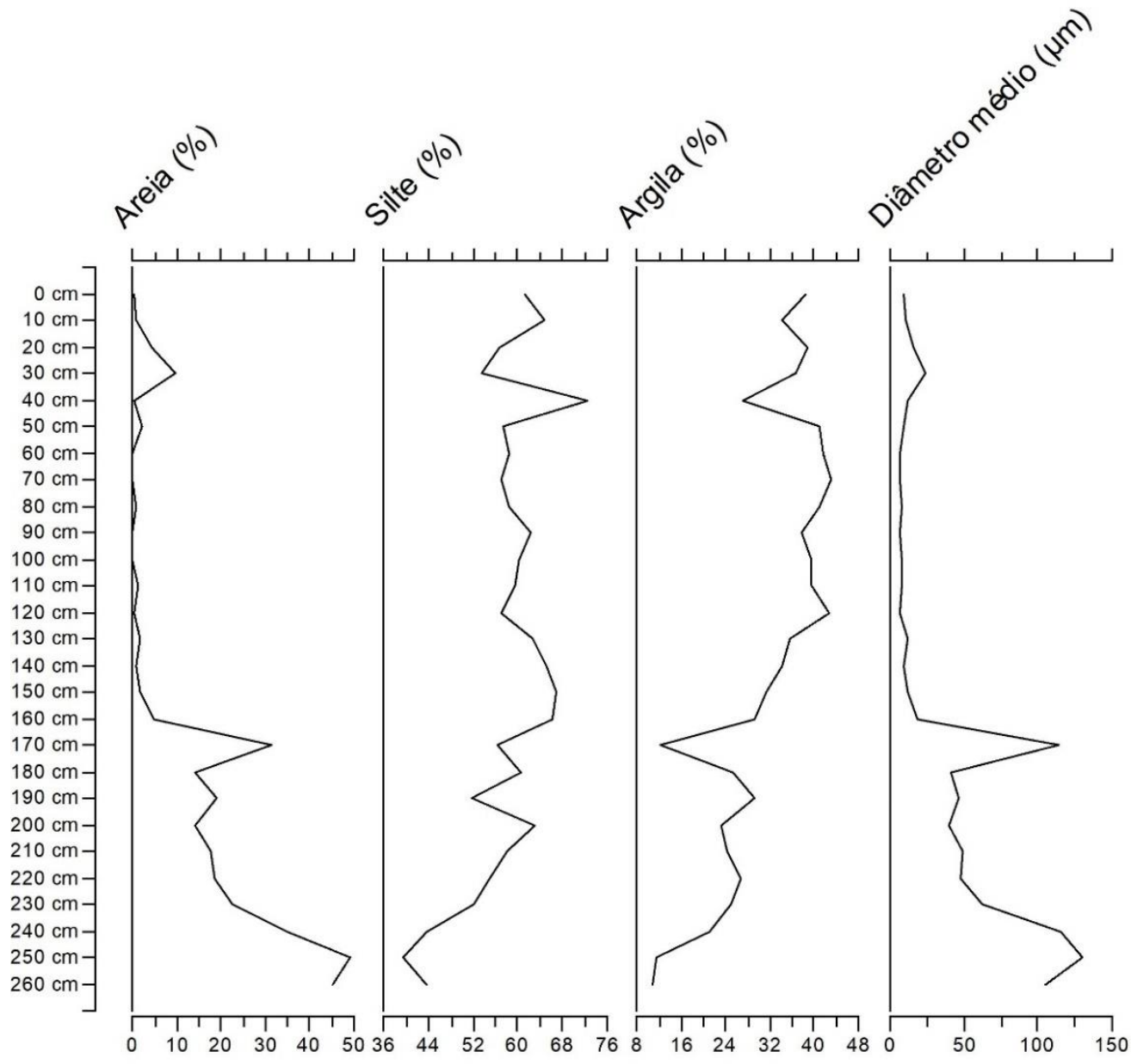

Figura 45. Representação gráfica dos dados granulométricos dos sedimentos da Lagoa Comprida, Afrânio - PE. Areia, silte e argila são apresentados em porcentagem e diâmetro médio em micrômetros.

Os dados granulométricos corroboram a seção estratigráfica, com o início do perfil composto por partículas mais finas (silte e argila), aumentando gradativamente de tamanho até o final (areia). Apesar de, em campo, termos determinado que a predominância era de argila, percebe-se na análise granulométrica o domínio de silte, que chega a atingir $72 \%$ do total dos sedimentos a $40 \mathrm{~cm}$. No entanto, as partículas de argila giram em volta de $40 \%$ até aproximadamente $150 \mathrm{~cm}$ de profundidade. 


\subsubsection{Palinologia}

As figuras 46,47 e 48 apresentam respectivamente as porcentagens dos elementos arbóreos, herbáceos e dos palinomorfos. A figura 49 a porcentagem das categorias e a figura 50 a concentração. O software CONISS reconheceu quatro zonas: KBC $1(260 \mathrm{~cm}$ a $235 \mathrm{~cm})$; KBC $2(235 \mathrm{~cm}$ a $175 \mathrm{~cm})$; KBC $3(175 \mathrm{~cm}$ a $65 \mathrm{~cm})$ e KBC $4(65 \mathrm{~cm}$ a $0 \mathrm{~cm})$, as quais são descritas a seguir:

KBC 1 (10.931 anos cal. AP - 9.815 anos cal. AP; $260 \mathrm{~cm}$ a $235 \mathrm{~cm}$ ): Esta zona é caracterizada pela presença de somente sete palinomorfos diferentes, que atingiram a concentração total de 3.500 palinomorfos $/ \mathrm{cm}^{3}$. Nas três amostras foram encontrados 27 grãos de pólen e 915 esporos exóticos de Lycopodium, em nove lâminas. Tal ocorrência está associada ao tipo de sedimento, caracterizado granulometricamente por $50 \%$ de areia. Os grãos de pólen encontrados nesta zona foram Melastomataceae com 194 grãos $/ \mathrm{cm}^{3}$, Myrtaceae com 1949 grãos $/ \mathrm{cm}^{3}$ e Paulinia, com 30 grãos $/ \mathrm{cm}^{3}$ entre os arbóreo/arbustivos, Poaceae com 194 grãos $/ \mathrm{cm}^{3}$ e Cyperaceae com 54 grãos $/ \mathrm{cm}^{3}$, entre os herbáceos terrestres e aquáticos, Coelastrum com 194 zigósporos $/ \mathrm{cm}^{3}$ entre as algas e Azolla e Lygodium com 61 e 182 esporos $/ \mathrm{cm}^{3}$, respectivamente, entre as pteridófitas.

KBC 2 (9.815 anos cal. AP - 7.148 anos cal. AP; $235 \mathrm{~cm}$ a $175 \mathrm{~cm}$ ): Esta zona se caracteriza pelo predomínio das ervas terrestres, que iniciam a zona com $58 \%$, atingem $71 \%$ e finalizam com $41 \%$, enquanto os arbóreos oscilam entre $31 \%$ e $16 \%$, sendo que a ca. 8.700 anos interpolados AP só houve a deposição de palmeiras entre os arbóreos. As ervas aquáticas iniciam com $2 \%$, aumentam para $18 \%$ e finalizam com 7\%. Em termos de concentração, os elementos arbóreos iniciam a zona com 464 grãos $/ \mathrm{cm}^{3}$ e finalizam com $2700 \mathrm{grãos} / \mathrm{cm}^{3}$, com o predomínio de Myrtaceae. As ervas terrestres iniciam com 871 e terminam com $2700 \mathrm{grãos} / \mathrm{cm}^{3}$, enquanto as pteridófitas têm grande oscilação ao longo da zona e iniciam com 464 esporos $/ \mathrm{cm}^{3}$, sobem para 1580, diminuem, aumentam, diminuem e finalmente finalizam a zona com 4000 esporos $/ \mathrm{cm}^{3}$. As ervas terrestres são dominadas por Poaceae $(10 \%-40 \%-10 \%) \mathrm{e}$ Araceae (45\%, 35\%, 40\% - 20\%), enquanto entre as aquáticas domina Cyperaceae, em torno de $20 \%$. Azolla inicia esta zona com $10 \%$, atinge $70 \%$ e finaliza a zona com $25 \%$. 

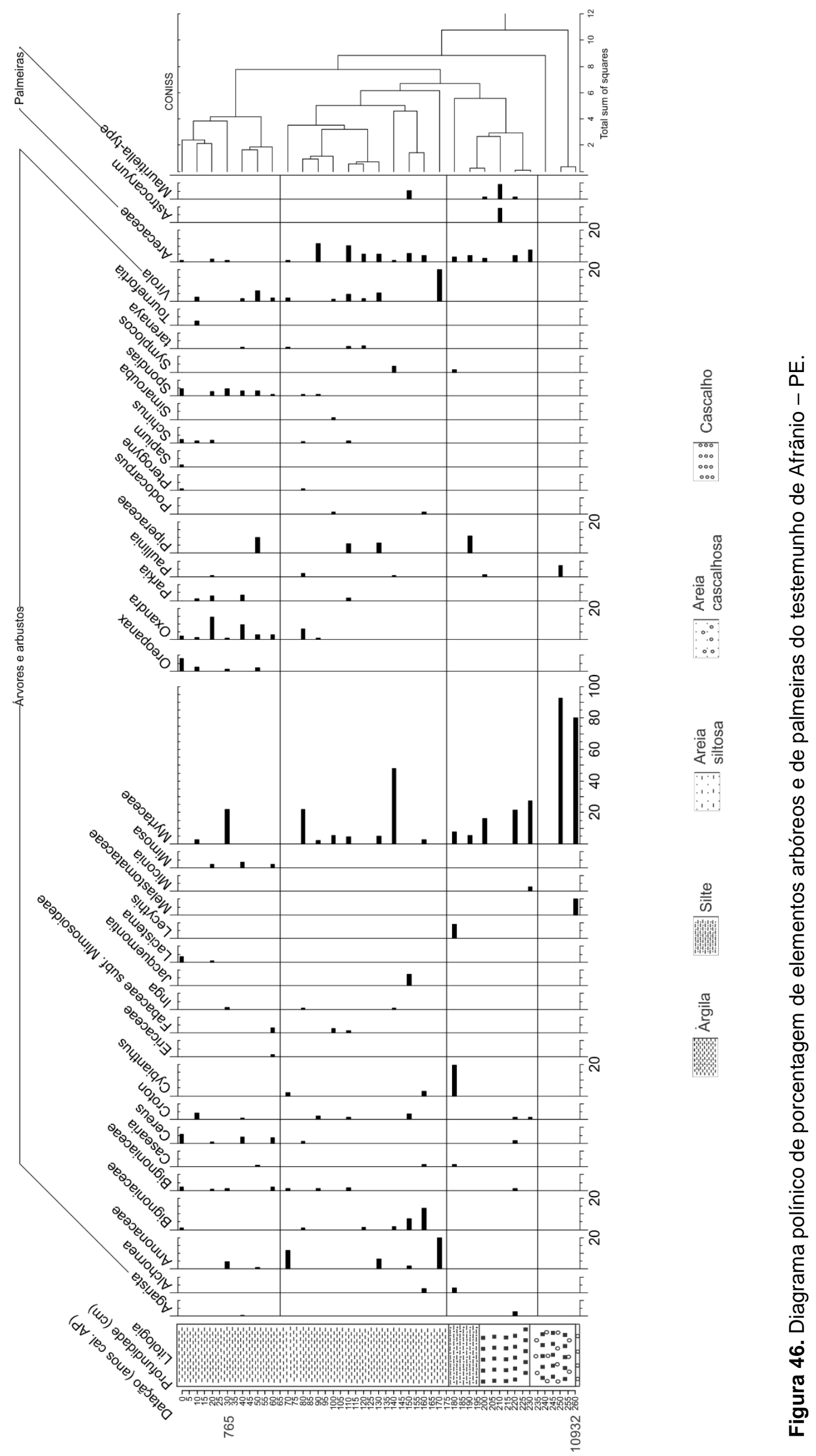

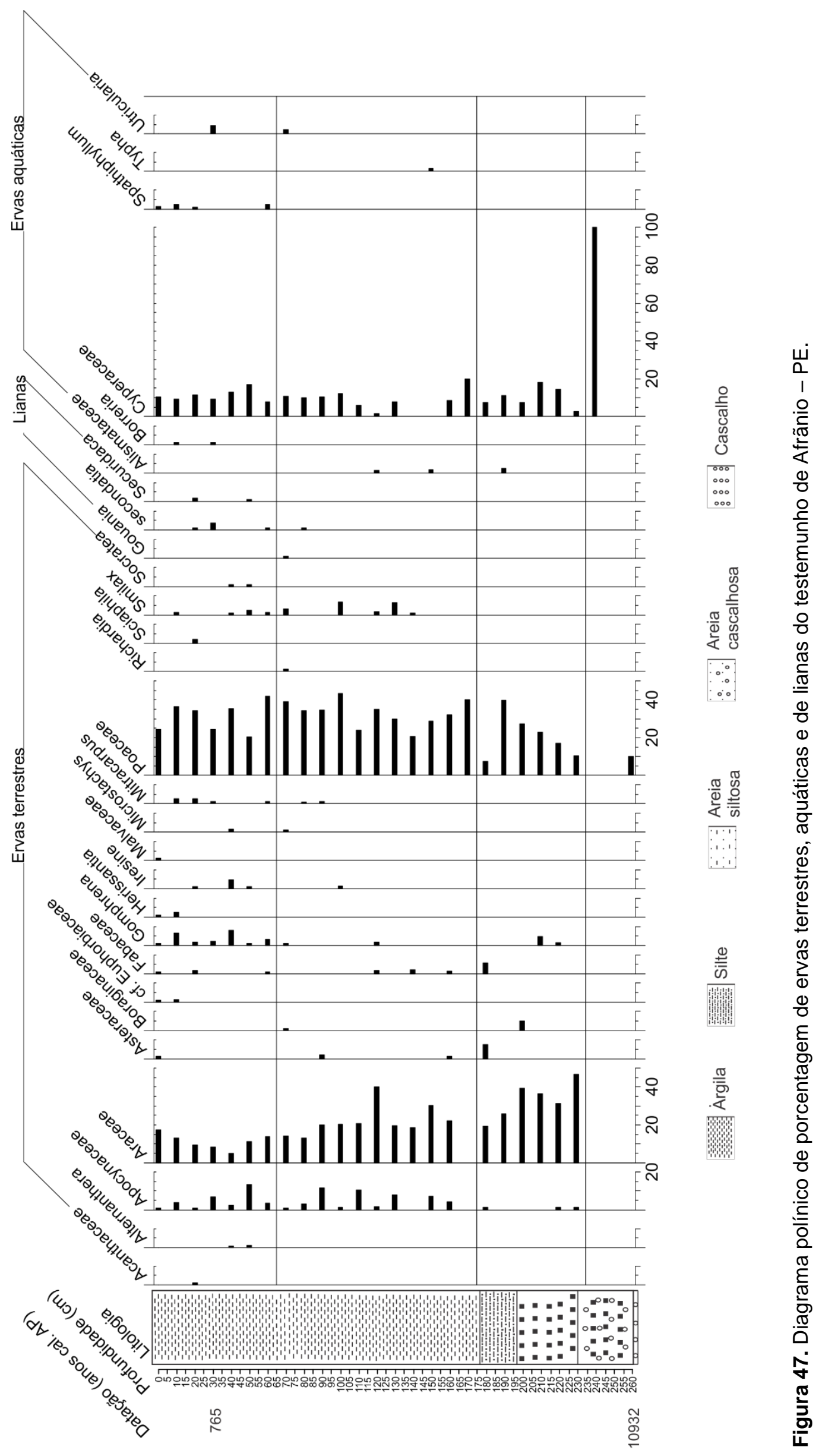


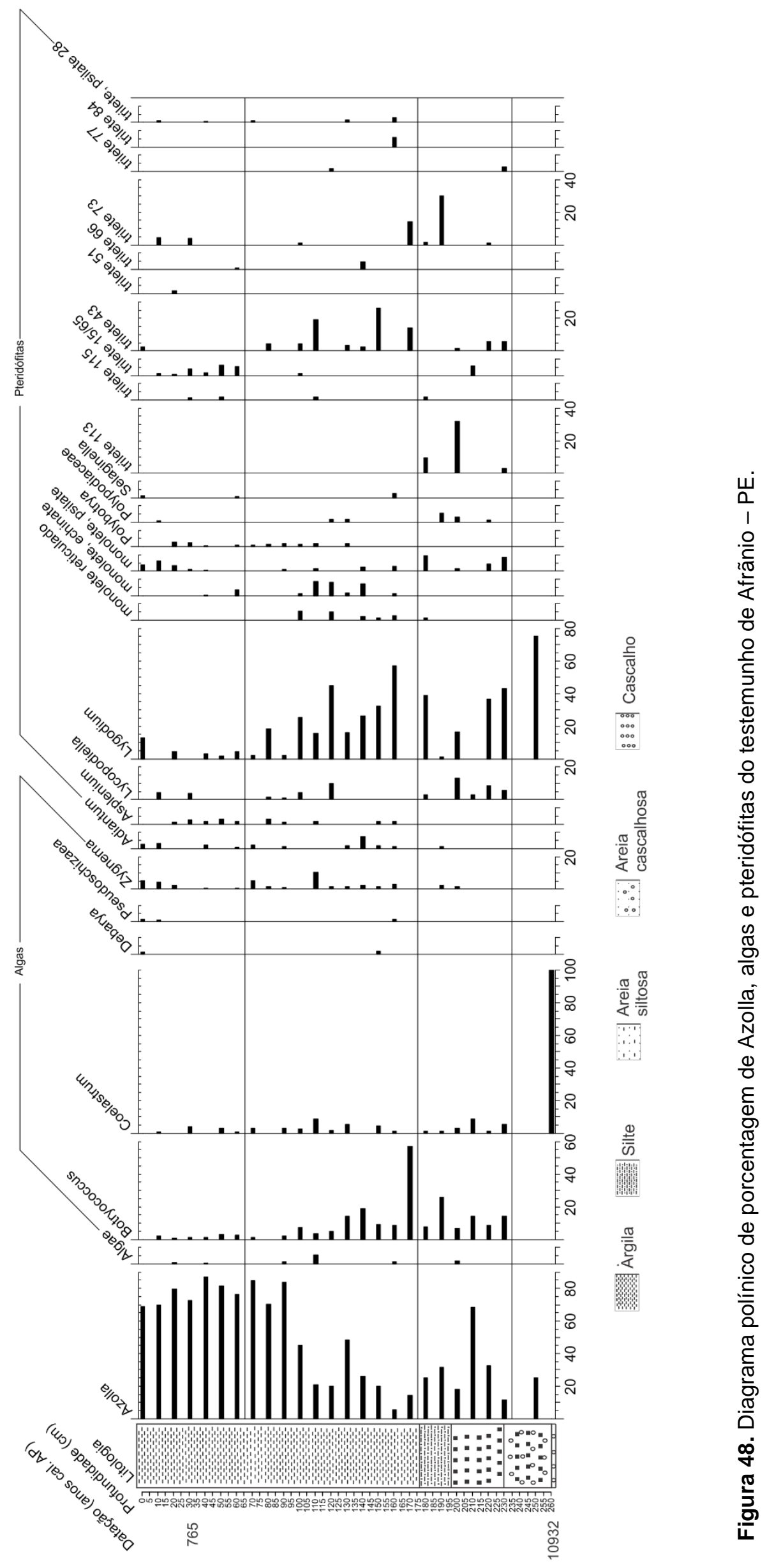



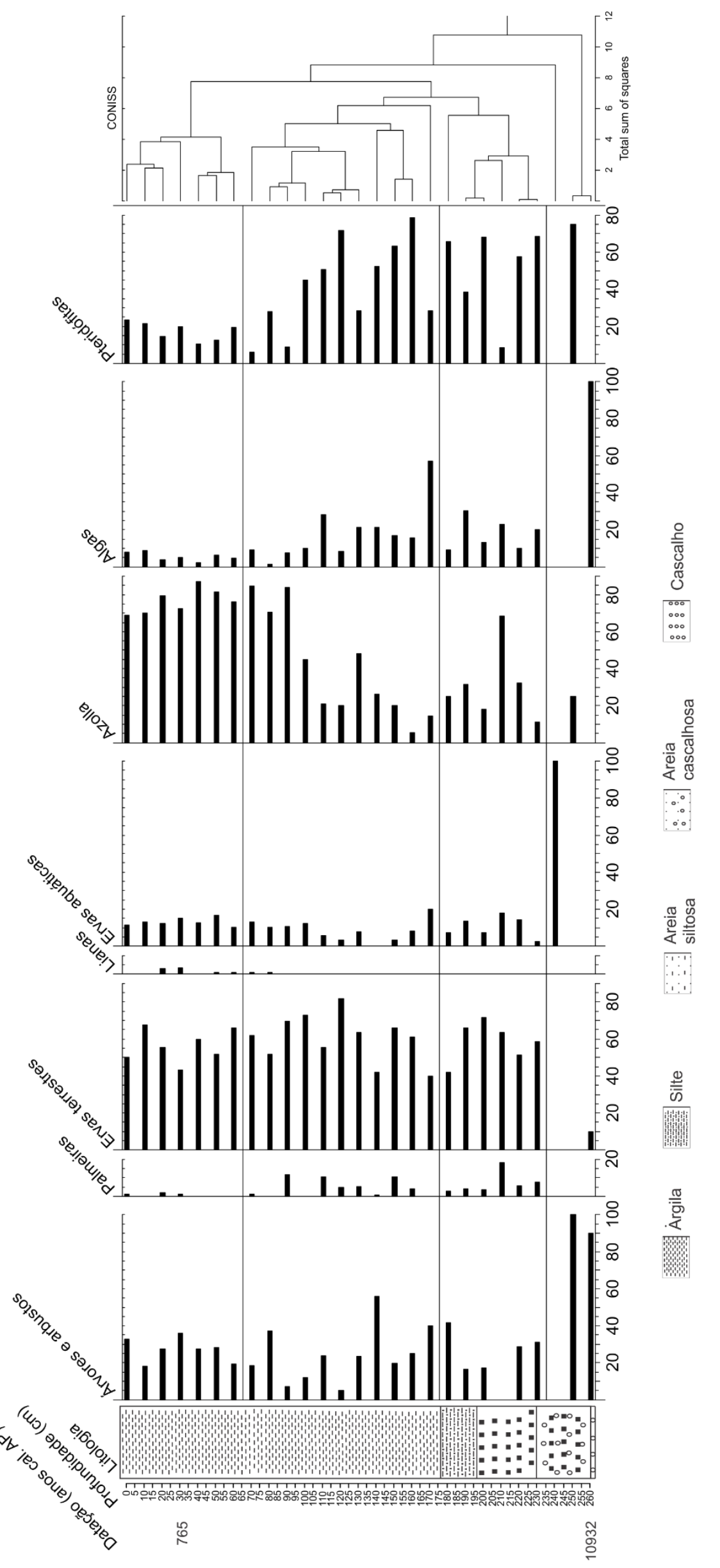

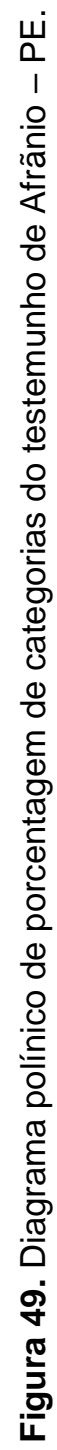




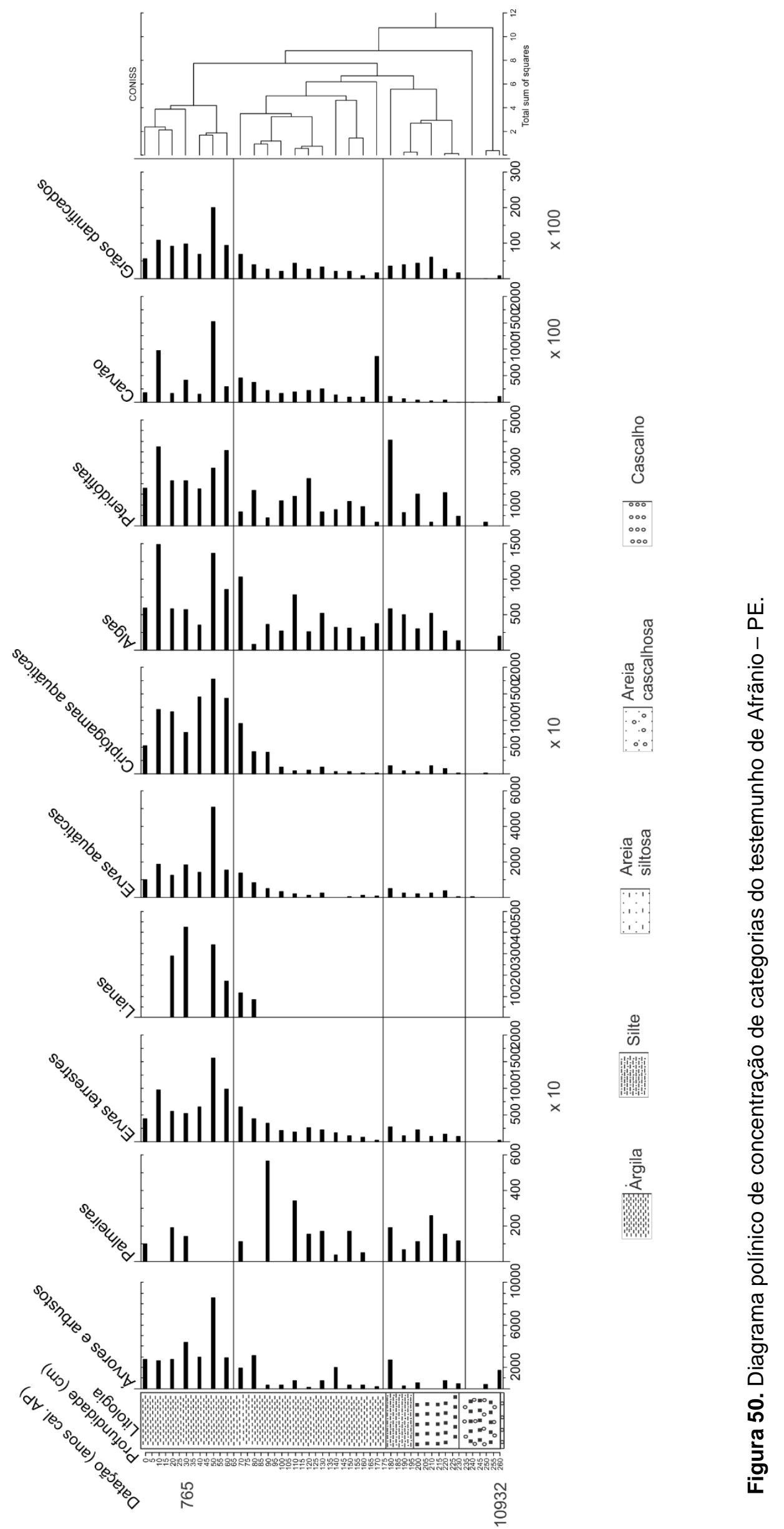


KBC 3 (7.148 anos cal. AP - 2.282 anos cal. AP; $175 \mathrm{~cm}$ a $65 \mathrm{~cm})$ : Esta zona se caracteriza pelo surgimento das lianas e pela maior concentração de palmeiras ao longo do perfil. Em termos gerais, os elementos arbóreos oscilam entre 55\% e 5\% e 186 para 2035, novamente 3098 grãos $/ \mathrm{cm}^{3}$, as palmeiras atingem $11 \%$ e 341 grãos $/ \mathrm{cm}^{3}$, os elementos herbáceos variam entre 40\% e $81 \%$ e 156 e 6537 grãos $/ \mathrm{cm}^{3}$. Azolla inicia com 14\% e termina a zona com $84 \%$ de 93 para 9405 mássulas $/ \mathrm{cm}^{3}$, ao mesmo tempo em que as algas passam de 57\% para 9\%, assim como as pteridófitas, que também diminuem de $78 \%$ para $6 \%$ ao término da zona. Inversamente, as concentrações das algas e das pteridófitas aumentam ao longo da zona e passam de 372 para 1032 zigósporos $/ \mathrm{cm}^{3}$ para as algas e 186 para 688 esporos $/ \mathrm{cm}^{3}$ para as pteridófitas. Individualmente, mesmo em pequenas quantidades, aparecem vários táxons novos nesta zona, dentro dos elementos arbóreos, tais como Annonaceae, Bignoniaceae, Mimosoide, Jacquemontia, Parkia, Podocarpus, Pterogyne, Schinus, Tarenaya e Virola. Entre as ervas terrestres há o predomínio de Apocynaceae, Araceae e Poaceae, além disso, surgem Iresine, Microstachys, Mitracarpus e Richardia. As lianas são representadas por Gouania, Secondatia e Securidaca. Já nas ervas aquáticas, Cyperaceae domina e ocorre o surgimento de Typha e Utricularia.

KBC 4 (2.282 anos cal. AP - atual; $65 \mathrm{~cm}$ a $0 \mathrm{~cm}$ ): Esta zona apresenta estabilidade entre as categorias, sem grandes oscilações percentuais, no entanto, em concentrações, há grandes oscilações. Os elementos arbóreos, que oscilaram em volta de $25 \%$, passam de 2900 para 8520 e voltam para 2780 grãos/cm³, enquanto as ervas terrestres, que se mantiveram na casa dos 55\%, passaram de 990 para 15700 e de volta para 4300 grãos $/ \mathrm{cm}^{3}$. As palmeiras não passaram de $194 \mathrm{grãos} / \mathrm{cm}^{3}$ e em algumas amostras não apareceram, assim como as lianas, que atingiram 435 grãos $/ \mathrm{cm}^{3}$. Os elementos aquáticos, ervas, Azolla e algas, atingiram seus maiores índices de concentração nesta zona, a saber: 5110, 17700 e 1400/cm³, respectivamente, por volta de 1.618 anos cal. AP. Neste mesmo momento, também houve a explosão de micropartículas de carvão e de grãos danificados, com 152000 e $20100 / \mathrm{cm}^{3}$, respectivamente. Dentre os elementos arbóreos surgem Ericaceae, Lacistema, Mimosa, Oreopanax e Sapium. Podocarpus desaparece, assim como Miconia, Melastomataceae, Lecythis, Cybianthus e Alchornea, assim como as palmeiras Astrocarium e Mauritiella-tipo. Nos elementos herbáceos, surgem 
Acanthaceae, Alternanthera, Euphorbiaceae, Herissantia, Malvaceae e Socratea e Borreria nas ervas aquáticas.

\subsubsection{Diatomáceas}

Nesta localidade foram identificados seis espécimes de diatomáceas, pertencentes aos gêneros: Amphora sp, Cyclotella sp, Cymbella sp, Gomphonema sp, Navicula sp e Pinnularia sp, além de frústulas quebradas e dissolvidas (Anexo 2). A análise quantitativa não foi realizada, devido à baixa quantidade de frústulas por lâmina (>20). 


\section{DENTES DE MEGAFAUNA}

Dentre os cinco dentes/fragmentos de dentes de Stegomastodon (Figura 51), foram recuperados microfósseis em quatro deles e somente três vestígios de tecido vegetal no quinto.

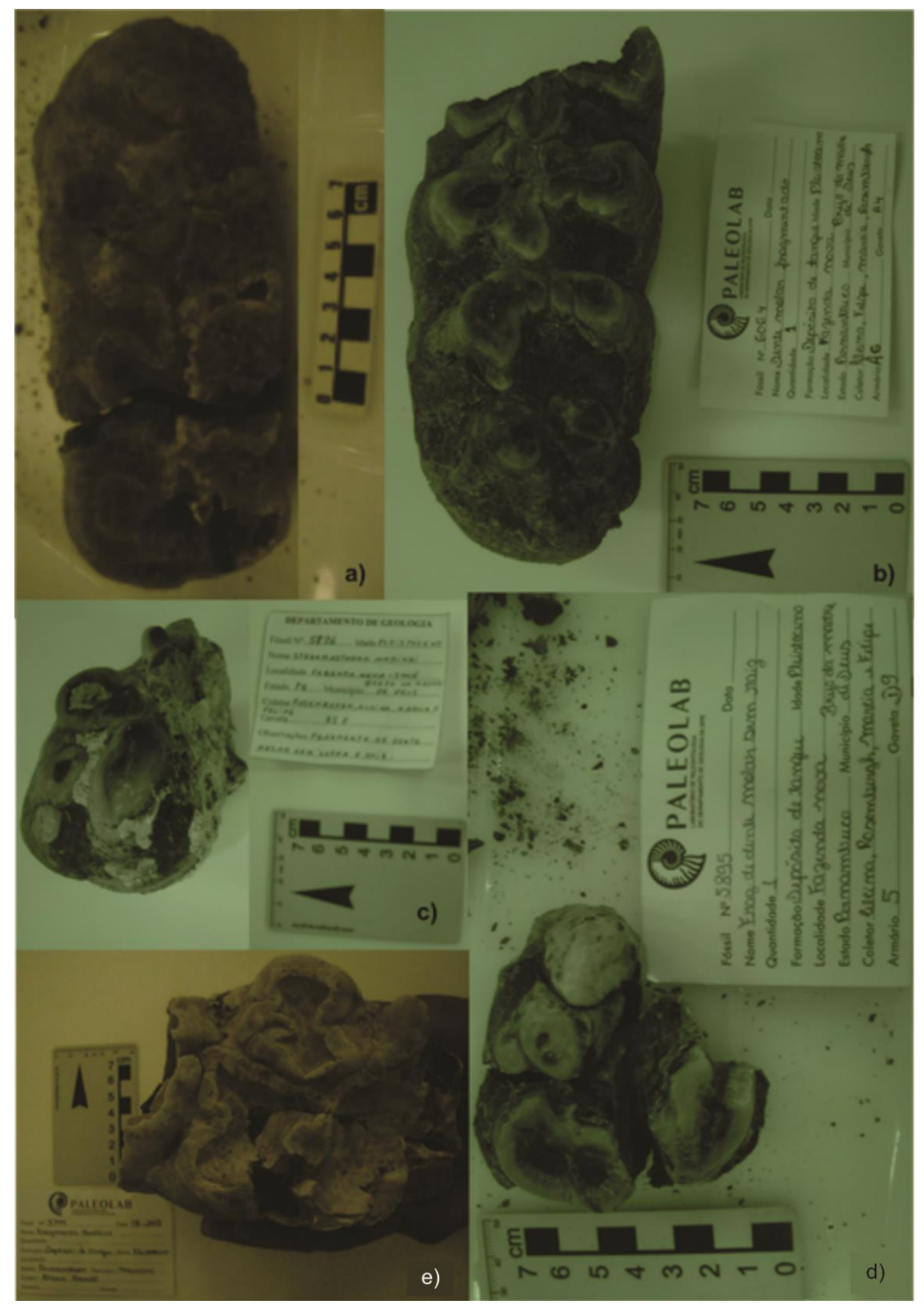

Figura 51. Fragmentos de molares de Stegomastodon. a) molar coletado na Fazenda Currais Queimados, em Capoeiras (PE); b, c, d, e) coleção científica da UFPE. Fotos: Vanda Medeiros. 
Os exemplares de dentes de megafauna que foram amostrados pertencem aos municípios de Capoeiras, Brejo da Madre de Deus e Manari, todos situados no estado de Pernambuco, conforme Tabela 7.

Tabela 7. Relação das amostras analisadas, número de código na coleção científica do Laboratório de Paleontologia do Departamento de Geologia da UFPE e município de origem.

\begin{tabular}{clll}
\hline Amostra & Código UFPE & Município & Tipo de peça \\
\hline A & Em incorporação & Capoeiras - PE & Molar \\
B & 6064 & Brejo da Madre de Deus - PE & Molar fragmentado \\
C & 5896 & Brejo da Madre de Deus - PE & Fragmento de molar \\
D & 5895 & Brejo da Madre de Deus - PE & Fragmento de molar \\
E & 5744 & Manari - PE & Fragmento de molar \\
\hline
\end{tabular}

\subsection{Resultados micropaleontológicos}

A análise micropaleontológica permitiu a recuperação de 12 grãos de pólen de táxons diferentes, dez morfotipos de fitólitos e três fragmentos de tecidos vegetais, que representam a vegetação presente na paisagem, assim como seis diatomáceas inteiras ou fragmentadas distintas e três morfotipos de espículas de esponjas dos reservatórios utilizados pelos animais.

A quantidade de microfósseis recuperados foi pequena, conforme demostrado na Tabela 8, que os apresenta, assim como resultados de porcentagem e concentração de cada um, isoladamente. A amostra A foi subdividida em duas subamostras, devido a um orifício no dente, preenchido com material escuro, o qual foi amostrado e processado separadamente dos cálculos dentários retirados da região gengival (Figura 52). A amostra B se mostrou infértil, conforme pode ser observado na figura 53. Dentre as amostras férteis, os grãos de pólen e os fragmentos vegetais estavam presentes em todas. No entanto, não havia fitólitos na amostra $D$, na amostra C não havia diatomáceas e nas amostras $C$, D e E não foram recuperadas espículas de esponjas. 
Tabela 8. Dados de porcentagem e concentração de palinomorfos e microfósseis silicosos encontrados em cada amostra analisada

\begin{tabular}{|c|c|c|c|c|c|c|c|c|c|c|c|}
\hline \multirow{2}{*}{ Grupo } & \multirow{2}{*}{ Elemento } & \multicolumn{2}{|c|}{ Dente A1 } & \multicolumn{2}{|c|}{ Dente A2 } & \multicolumn{2}{|c|}{ Dente C } & \multicolumn{2}{|c|}{ Dente D } & \multicolumn{2}{|c|}{ Dente $\mathrm{E}$} \\
\hline & & $\%$ & $\mathrm{C}$ & $\%$ & $\mathrm{C}$ & $\%$ & C & $\%$ & C & $\%$ & C \\
\hline Pólen & Alchornea & 0.0 & 0 & 0.0 & 0 & 0.0 & 0 & 4.5 & 19 & 7.7 & 74 \\
\hline Pólen & Asteraceae & 7.7 & 163 & 0.0 & 0 & 0.0 & 0 & 0.0 & 0 & 0.0 & 0 \\
\hline Pólen & Mimosa 01 & 0.0 & 0 & 1.8 & 65 & 0.0 & 0 & 0.0 & 0 & 0.0 & 0 \\
\hline Pólen & Mimosa 02 & 0.0 & 0 & 0.0 & 0 & 0.0 & 0 & 4.5 & 19 & 0.0 & 0 \\
\hline Pólen & Myrsine & 3.8 & 81 & 0.0 & 0 & 0.0 & 0 & 0.0 & 0 & 7.7 & 74 \\
\hline Pólen & Myrtaceae & 0.0 & 0 & 0.0 & 0 & 0.0 & 0 & 0.0 & 0 & 7.7 & 74 \\
\hline Pólen & Poaceae & 3.8 & 81 & 0.0 & 0 & 13.0 & 285 & 18.2 & 76 & 0.0 & 0 \\
\hline Pólen & Podocarpus & 0.0 & 0 & 0.0 & 0 & 2.2 & 48 & 0.0 & 0 & 7.7 & 74 \\
\hline Pólen & Solanaceae & 0.0 & 0 & 0.0 & 0 & 0.0 & 0 & 4.5 & 19 & 0.0 & 0 \\
\hline Pólen & Typha & 0.0 & 0 & 0.0 & 0 & 4.3 & 95 & 0.0 & 0 & 0.0 & 0 \\
\hline Pólen & Indt 19 & 0.0 & 0 & 0.0 & 0 & 2.2 & 48 & 0.0 & 0 & 0.0 & 0 \\
\hline Pólen & Indt 21 & 0.0 & 0 & 0.0 & 0 & 0.0 & 0 & 4.5 & 19 & 0.0 & 0 \\
\hline Fitólito & 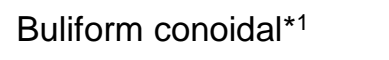 & 0.0 & 0 & 1.8 & 65 & 0.0 & 0 & 0.0 & 0 & 0.0 & 0 \\
\hline Fitólito & 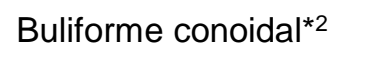 & 7.7 & 163 & 1.8 & 65 & 2.2 & 48 & 0.0 & 0 & 0.0 & 0 \\
\hline Fitólito & Buliforme paralelipdal*2 $^{\star 2}$ & 3.8 & 81 & 0.0 & 0 & 0.0 & 0 & 0.0 & 0 & 0.0 & 0 \\
\hline Fitólito & Cyperus & 7.7 & 163 & 1.8 & 65 & 17.4 & 381 & 0.0 & 0 & 7.7 & 74 \\
\hline Fitólito & Elongate $^{\star 2}$ & 3.8 & 81 & 0.0 & 0 & 0.0 & 0 & 0.0 & 0 & 0.0 & 0 \\
\hline Fitólito & Globular equinate ${ }^{\star 3}$ & 0.0 & 0 & 1.8 & 65 & 0.0 & 0 & 0.0 & 0 & 0.0 & 0 \\
\hline Fitólito & Globular granulate ${ }^{* 4}$ & 0.0 & 0 & 1.8 & 65 & 0.0 & 0 & 0.0 & 0 & 0.0 & 0 \\
\hline Fitólito & Tabular retangular $01^{\star 2}$ & 7.7 & 163 & 0.0 & 0 & 0.0 & 0 & 0.0 & 0 & 0.0 & 0 \\
\hline Fitólito & Tabular retangular $02^{\star 2}$ & 3.8 & 81 & 0.0 & 0 & 0.0 & 0 & 0.0 & 0 & 0.0 & 0 \\
\hline Fitólito & Tabular retangular $03^{\star 2}$ & 3.8 & 81 & 0.0 & 0 & 0.0 & 0 & 0.0 & 0 & 0.0 & 0 \\
\hline Vegetal & Fragmento Vegetal 01 & 23.1 & 488 & 40.0 & 1431 & 58.7 & 1285 & 50.0 & 209 & 53.8 & 519 \\
\hline Vegetal & Tricoma 01 & 3.8 & 81 & 0.0 & 0 & 0.0 & 0 & 0.0 & 0 & 0.0 & 0 \\
\hline Vegetal & Tricoma 02 & 3.8 & 81 & 0.0 & 0 & 0.0 & 0 & 0.0 & 0 & 0.0 & 0 \\
\hline Diatomácea & Cyclotella & 0.0 & 0 & 5.5 & 195 & 0.0 & 0 & 0.0 & 0 & 0.0 & 0 \\
\hline Diatomácea & Diatomácea 03 & 0.0 & 0 & 1.8 & 65 & 0.0 & 0 & 0.0 & 0 & 0.0 & 0 \\
\hline Diatomácea & Diatomácea 04 & 0.0 & 0 & 1.8 & 65 & 0.0 & 0 & 0.0 & 0 & 0.0 & 0 \\
\hline Diatomácea & Navicula & 0.0 & 0 & 1.8 & 65 & 0.0 & 0 & 9.1 & 38 & 0.0 & 0 \\
\hline Diatomácea & Eunotia & 7.7 & 163 & 5.5 & 195 & 0.0 & 0 & 0.0 & 0 & 0.0 & 0 \\
\hline Diatomácea & Fragmento Diatomácea & 3.8 & 81 & 0.0 & 0 & 0.0 & 0 & 4.5 & 19 & 7.7 & 74 \\
\hline Espícula & Espícula 01 & 3.8 & 81 & 21.8 & 780 & 0.0 & 0 & 0.0 & 0 & 0.0 & 0 \\
\hline Espícula & Espícula 02 & 0.0 & 0 & 5.5 & 195 & 0.0 & 0 & 0.0 & 0 & 0.0 & 0 \\
\hline Espícula & Espícula 03 & 0.0 & 0 & 5.5 & 195 & 0.0 & 0 & 0.0 & 0 & 0.0 & 0 \\
\hline
\end{tabular}




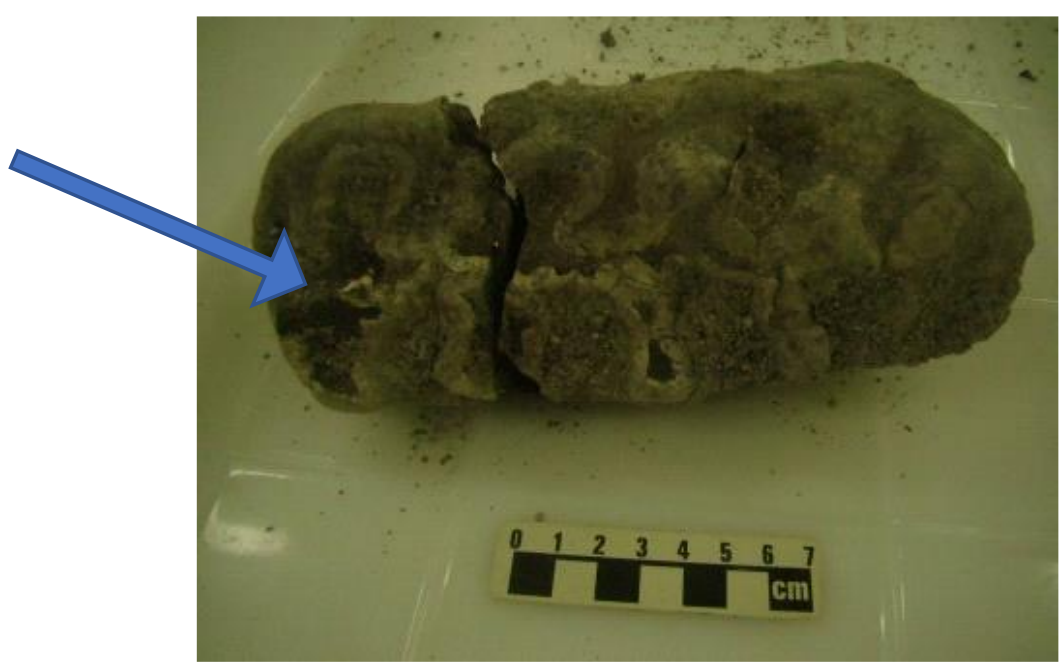

Figura 52. Dente molar de Stegomastodon waringi, coletado no município de Capoeiras - PE. A seta indica o orifício presente no dente, de onde foi coletado material para análise, além do cálculo. Foto: Vanda Medeiros

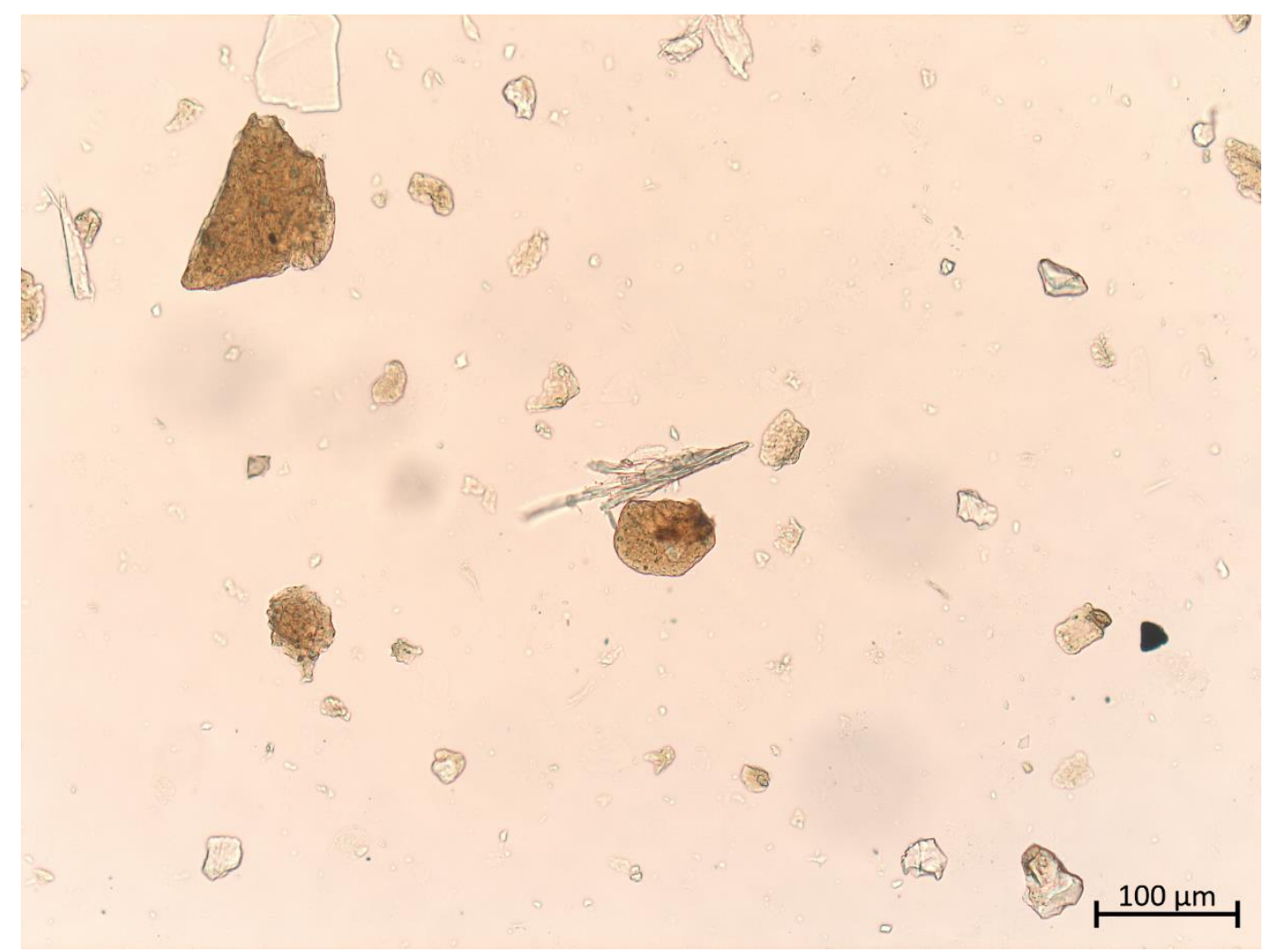

Figura 53. Microfotografia do campo de visão de lâmina da amostra B, molar fragmentado coletado no município de Brejo da Madre de Deus - PE, onde se percebe que não há microfósseis de valor diagnóstico. Foto: Maicon Alicrin.

A figura 54 mostra a porcentagem e concentração dos diferentes grupos recuperados, para tanto, a porcentagem foi realizada com base no número total de 
indivíduos, independentemente de ser grão de pólen, fitólitos, fragmentos vegetais, diatomáceas ou espículas de esponjas.

Em termos de porcentagem, o grupo mais representado entre todos os recuperados foram os fragmentos vegetais, com variação entre $30 \%$ no dente coletado no município de Capoeiras (Amostra A1) e 58\% no dente coletado no município de Brejo da Madre de Deus (Amostra C). Os grãos de pólen variaram entre 1,8\% (Amostra A2) e 36,3\% (Amostra D) e os fitólitos entre 7,6\% (Amostra E) e 38,4\% (Amostra A1).

Os resultados obtidos na análise dos cálculos dentários de Stegomastodon reconstituem uma floresta arbórea arbustiva, formada por árvores pertencentes aos gêneros Podocarpus, Myrsine, Mimosa, Alchornea e representantes das famílias Myrtaceae e Solanaceae, além de ervas terrestres, como Asteraceae e Poaceae e aquáticas como Typha, identificados através dos grãos de pólen. Estas árvores apresentam, quando adultas e nos dias atuais, a altura mínima de três metros e as frações isotópicas com variação entre -24,96 e -34,5 (Tabela 9), características de plantas com ciclo fotossintético C3 (Pessenda et al., 2010a) e, em sua maioria, são normalmente encontradas na Mata Atlântica (Lorenzi, 1992, 2009; Garcia, 2003; Mofatto, 2005; Reflora, 2019) e em outros ecossistemas florestais tropicais úmidos (Marchant and Hooghiemstra, 2004). Os fitólitos identificados também revelam a presença de elementos arbóreos, tais como Arecaceae e dicotiledôneas lenhosas, além de ervas terrestres - Poaceae C4 e aquáticas Cyperus e Oryzeae (Poaceae). Os fragmentos vegetais, tal como os fitólitos, são indicativos de dicotiledôneas lenhosas. Arecaceae apresenta $\delta^{13} \mathrm{C}$ por volta de $-33,0$ (Martinelli et al., 1998) e todas as gramíneas da Tribo Oryzeae são C3 (Barboni e Bremond, 2009; Longhi-Wagner, 2012), assim como as ciperáceas (Mofatto, 2005) e as dicotiledôneas lenhosas (Martinelli et al., 1998; Mofatto, 2005). 


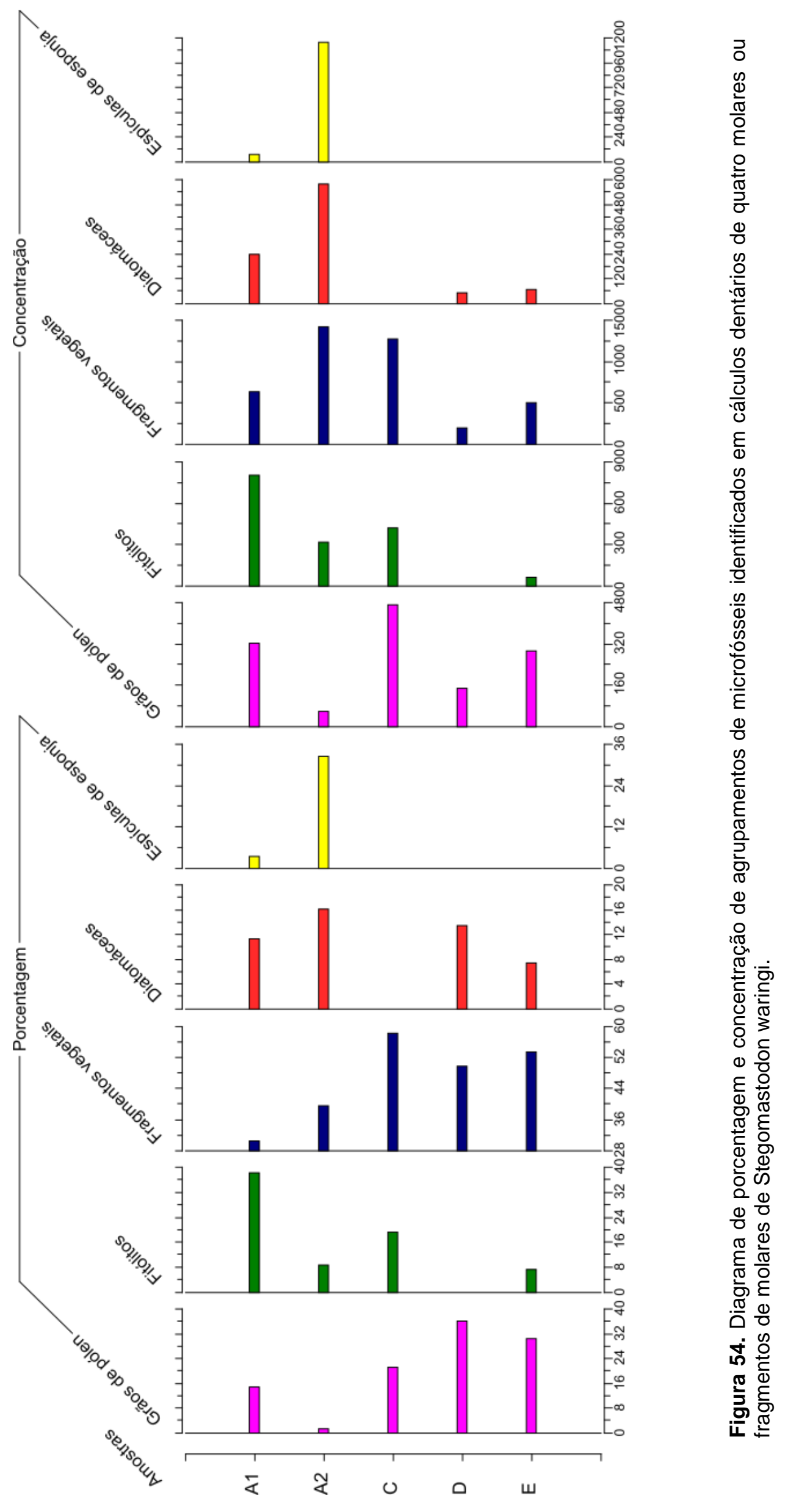


Tabela 9. Classificação quanto ao hábito dos táxons identificados, com altura mínima e sua fração $\delta^{13} \mathrm{C}$. As referências estão relacionadas abaixo.

\begin{tabular}{|c|c|c|c|c|}
\hline $\begin{array}{l}\text { Família } \\
\text { Gênero }\end{array}$ & Hábito & Altura mínima (m) & $\delta 13 C$ & $\begin{array}{l}\text { Referência } \\
\text { Alt }-\delta^{13} \mathrm{C}\end{array}$ \\
\hline $\begin{array}{l}\text { Asteraceae } \\
\text { Euphorbiace }\end{array}$ & Erva terrestre & 0,3 & média - 29 & $1-1$ \\
\hline $\begin{array}{l}\text { Alchornea } \\
\text { Mimosoide }\end{array}$ & Árvore & 10 & -29 & $2-2$ \\
\hline $\begin{array}{l}\text { Mimosa } \\
\text { Myrsinaceae }\end{array}$ & Árvore & 5 & média - 30 & $2-3$ \\
\hline Myrsine & Árvore & 3 & -29 & $2-1$ \\
\hline Myrtaceae & Árvore & 3 & média - 30 & $2-1$ \\
\hline $\begin{array}{l}\text { Poaceae } \\
\text { Podocarpace }\end{array}$ & Erva terrestre & 0,3 & média - 19 & $1-1$ \\
\hline Podocarpus & Árvore & 8 & $-28,6$ & $2-1$ \\
\hline $\begin{array}{l}\text { Solanaceae } \\
\text { Typhaceae }\end{array}$ & Árvore & 3 & $-30,1$ & $3-4$ \\
\hline Typha & Erva aquática & 2 & $-27,7$ & $1-3$ \\
\hline
\end{tabular}




\section{DISCUSSÃO}

\subsection{Micropaleontologia de sedimentos ricos em restos de Megafauna do NEB e de outros depósitos estudados}

\subsubsection{Palinologia}

- A idade mais antiga alcançada nos sedimentos estudados foi de 34.935 anos cal. AP, em São Bento do Una e está inserida entre os eventos climáticos globais H3 (ca. 30.000 a 32.000 anos AP) e H4 (ca. 38.000 a 40.000 anos AP), os quais tiveram impacto no NEB, em termos de umidade, com aumento de precipitação (Jaeschke et al., 2007; Wang et al., 2008; Cruz et al., 2009). Entre esta idade e 9.685 anos cal. AP, a vegetação local era rica em espécies e abundante, com estratos arbóreos, arbustivos e herbáceos, característicos de ambientes mais úmidos e com temperaturas mais amenas do que as atuais. Havia elementos hoje distribuídos somente na Mata Atlântica e Floresta Amazônica (Anexo 4), tais como Galianthe, Hiraea e Myriophyllum (Reflora, 2019), além daquelas encontradas em florestas úmidas, entre elas: Simarouba, Piptadenia, Melastomataceae, Myrtaceae, Copaifera, além da presença de elementos montanos, como Podocarpus, Hedyosmum e Symplocos assim como Melastomataceae e Myrtaceae. Esta assembleia corrobora a existência de vegetação de clima mais frio e úmido que o atual (Colinvaux et al., 1996a; Colinvaux e De Oliveira, 2001; Oliveira et al., 2005; Pessenda et al., 2009).

Atualmente, Podocarpus só é encontrado em Brejos de altitude (acima de 900 m) no interior do NEB (Sales et al., 1998; Locatelli e Machado, 2004; Cavalcanti e Tabarelli, 2004; Ledru et al., 2007; Locosselli e Ceccantini, 2012; Locosselli et al., 2016). A presença deste elemento em regiões do NEB é possível devido à sua adaptabilidade anatômica, com maior densidade de estômatos e menor diâmetro de traqueídeos que os indivíduos que vivem sob condições de clima frio e úmido (Locosselli e Ceccantini, 2012). Além disso, Locosselli et al. (2016) determinaram diminuição de temperatura em aproximadamente $5^{\circ} \mathrm{C}$ e aumento de $12 \%$ de umidade, além da diminuição da alternância destas variantes ao longo do tempo em brejos de altitude com afloramentos rochosos, os quais permitem o estabelecimento de microclimas.

A ocorrência atual mais próxima de Podocarpus ocorre em um Brejo de altitude no município de Caruaru - PE (Sales et al., 1998; Ledru et al., 2007), que se localiza a $57 \mathrm{~km}$ de distância do ponto de coleta, em São Bento do Una, que se encontra a 
$840 \mathrm{~m}$ de altitude (Figura 55), onde Podocarpus atingiu 0,71\% de distribuição polínica e $432 \mathrm{grãos} / \mathrm{cm}^{3}$ nos sedimentos analisados, com idades entre ca. 34.000 e 19.000 anos cal. AP, em contraste com a variação entre $2 \%$ e $5 \%$ em floresta alto-montana na Serra do Mar, em São Paulo (Pessenda et al., 2009) e 0 a 6,5\% no Lago Caço MA (Ledru et al., 2001, 2007) e 1 a 8\% em Salitre - MG (Ledru, 1993; Ledru et al., 2007) em regiões de cerrado.

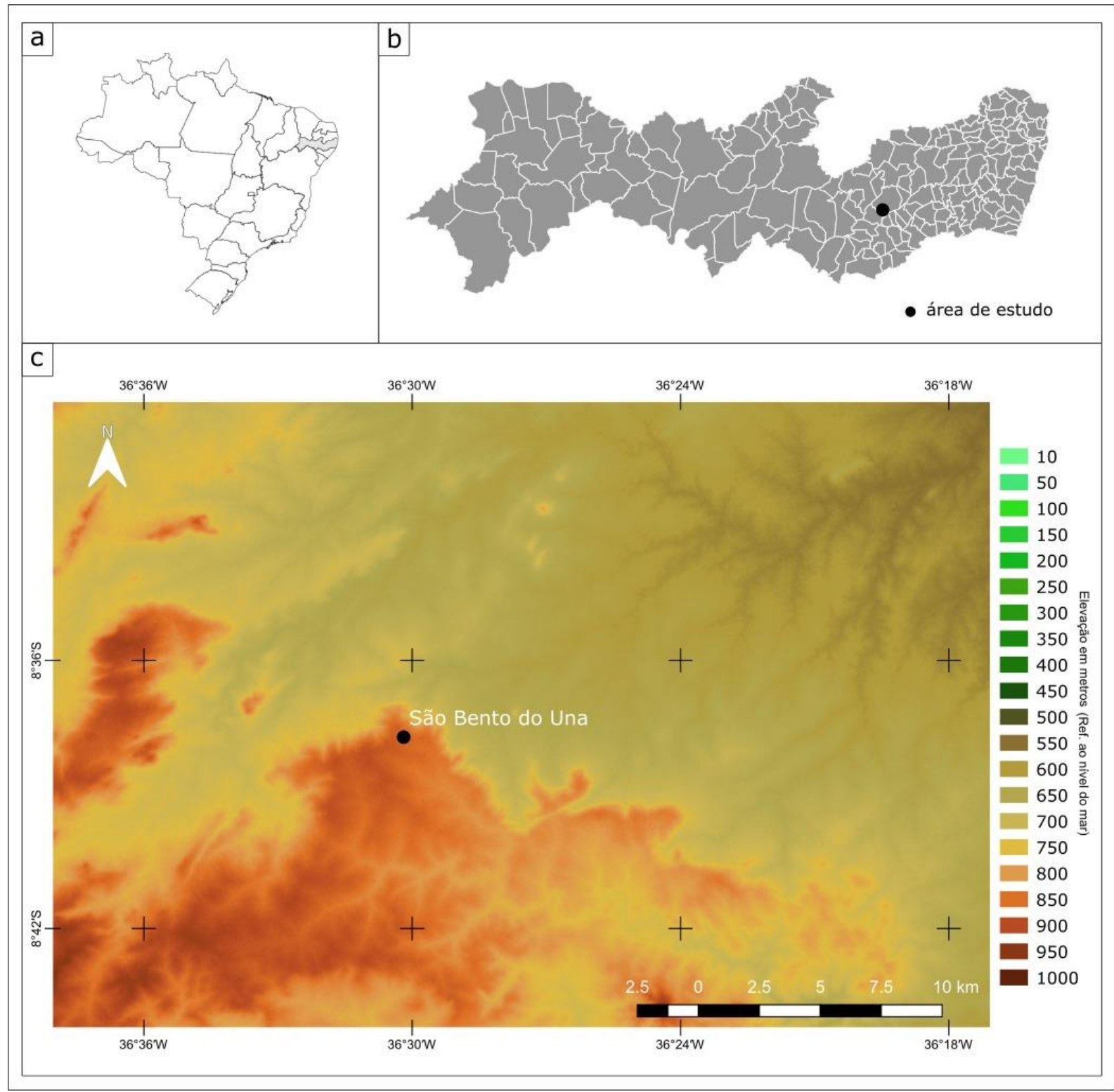

Figura 55. Mapa de relevo do ponto de coleta em São Bento do Una - PE, onde foram identificados grãos de pólen da conífera Podocarpus, hoje restrita a Brejos de Altitude no NEB. A altitude desta localidade sugere que este local pode ter apresentado a configuração climática de um Brejo de Altitude no passado. 
Ainda neste período, a presença de ervas aquáticas, tais como Borreria, Cyperaceae, Myriophyllum, Nymphaeaceae e Saggitaria, associadas à criptógama aquática Azolla, que chega a atingir 15.000 mássulas $/ \mathrm{cm}^{3}$, corroboram uma época mais úmida que o atual, com a presença de lagos na região. Este clima mais úmido que $o$ atual é ainda percebido através da baixa quantidade de micropartículas carbonizadas acima de $100 \mu \mathrm{m}$, que atingem o máximo de $864 / \mathrm{cm}^{3}$ no período, em contraste com 200.000 partículas $/ \mathrm{cm}^{3}$ encontradas em Cromínia, região de cerrado, que foram interpretadas como diminuição de incêndios (Salgado-Labouriau et al. 1998). A presença de grãos quebrados nesta zona é elevada, com pico de $16.600 / \mathrm{cm}^{3}$. A ocorrência deste tipo de grão geralmente está ligada à exposição subaérea e nova redeposição (Campbell, 1991) e, portanto, deve ser interpretada como ocorrência de menor umidade em um ciclo úmido.

- O próximo intervalo de idades compreende o início do Holoceno (ca. 10.500 anos cal. AP) até aproximadamente 6.000 anos cal. AP e abrange quatro localidades: São Bento do Una, Afrânio, Vale do Catimbau (PE) e São João do Cariri (PB).

Em São Bento do Una ocorreu uma grande alteração na paisagem neste período, em que os sedimentos se alteram de areia argilosa para areia. Tal evento configura a ocorrência de fluxo de maior energia, como o ocorrido na Bacia do Rio Parnaíba, no estado do Piauí (Mendes, 2016) e, consequentemente, a deposição e/ou preservação de grãos de pólen foi muito baixa. Neste intervalo, que aqui se estendeu até ca. 1.400 anos cal. AP, foram encontrados somente dez táxons diferentes entre arbóreos, ervas terrestres e aquáticas e pteridófitas. A maior concentração encontrada foi em Azolla, com 605 mássulas $/ \mathrm{cm}^{3}$, seguido por Poaceae, com $504 \mathrm{grãos} / \mathrm{cm}^{3}$. Os elementos presentes nas amostras permitem inferir uma paisagem com árvores esparsas, com ervas terrestres ao seu redor e ervas aquáticas ao longo do rio, além da criptógama Azolla se desenvolvendo em poças formadas na região devido ao acúmulo de chuvas. Neste período, não houve deposição de grãos danificados, que podem ter sido totalmente destruídos ou carregados e as micropartículas carbonizadas maiores que $100 \mu \mathrm{m}, \mathrm{com} 1.000 / \mathrm{cm}^{3}$, indicam a ocorrência de pequeno foco de incêndio no início da zona.

A vegetação do Vale do Catimbau durante o Holoceno, a partir de 10.322 anos cal. AP, pode ser interpretada como um ecossistema local em forma de oásis dentro do domínio semi-árido, com a umidade sendo mantida devido às condições 
geológicas, estruturais e de sedimentação locais, que favoreceu e proporcionou que a região, a partir de uma fonte de água subterrânea de um aquifero profundo (CPRM, 1964; Gomes, 1995; Nascimento, 2008), desenvolvesse uma vegetação exuberante e diferenciada de seu entorno. Esta configuração ambiental funciona como um refúgio para elementos arbóreos e herbáceos, encontrados em florestas úmidas, tais como: Cecropia, Cedrela, Simarouba, Piptadenia, Melastomataceae, Myrtaceae, Copaifera, assim como Orbignya, uma palmeira tipicamente indicativa de ambientes úmidos (Lorenzi, 1992), assim como justifica a abundância de Spathiphyllum em todo o testemunho. Esta erva, restrita a rochas e solos úmidos (Croat, 1988) em regiões semi-áridas, permaneceu estável no Catimbau, apesar das flutuações climáticas regionais durante o Holoceno.

A ocorrência de Cecropia neste período é significante, uma vez que é um gênero de árvores pioneiras, predominante em vegetações secundárias e geralmente é indicativa de eventos sucessionais sob climas úmidos ou mantidos por condições de umidade edáficas (Lorenzi, 1998).

A assinatura polínica do Catimbau é de amplitude local e não regional, devido ao anfiteatro rochoso no qual está inserida a turfeira (Figura 56) e, desta forma, é restrita e abundante, mantida por árvores e ervas locais, mascarando fontes anemófilas regionais. No entanto, é de salientar a presença de Ziziphus, muito provavelmente $Z$. joazeiro, uma conhecida espécie arbórea perene da Caatinga xerofítica da região do Sertão Nordestino, fato que sugere uma vegetação semiárida próxima ao redor deste local úmido, ao longo do Holoceno.

A configuração vegetal do início do Holoceno em Afrânio, município localizado a $504 \mathrm{~km}$ de distância de São Bento do Una, era similar ao ocorrido neste último, uma vez que entre 10.932 anos cal. AP e ca. 9.100 anos cal. AP foram identificados poucos grãos de pólen, associados a sedimentos compostos por $50 \%$ de areia, e grãos de $130 \mu \mathrm{m}$ de diâmetro, que caracteriza um ambiente de alta energia. Entre os arbóreos ocorreram Myrtaceae, Melastomataceae e Paullinia. Poaceae foi a única erva terrestre, Azolla, e Coelastrum foram as representantes aquáticas. Apesar de também apresentar baixa quantidade de elementos, a diferença entre as duas localidades é marcante, pois todos os táxons são representantes de florestas úmidas (De Oliveira et al., 1999), com exceção de Poaceae, que infelizmente não é possível identificar a nível de gênero ou mesmo Tribo, para a determinação de indivíduos com ciclo fotossintético C3 (Piperno, 2006; Watling et al., 2017). 


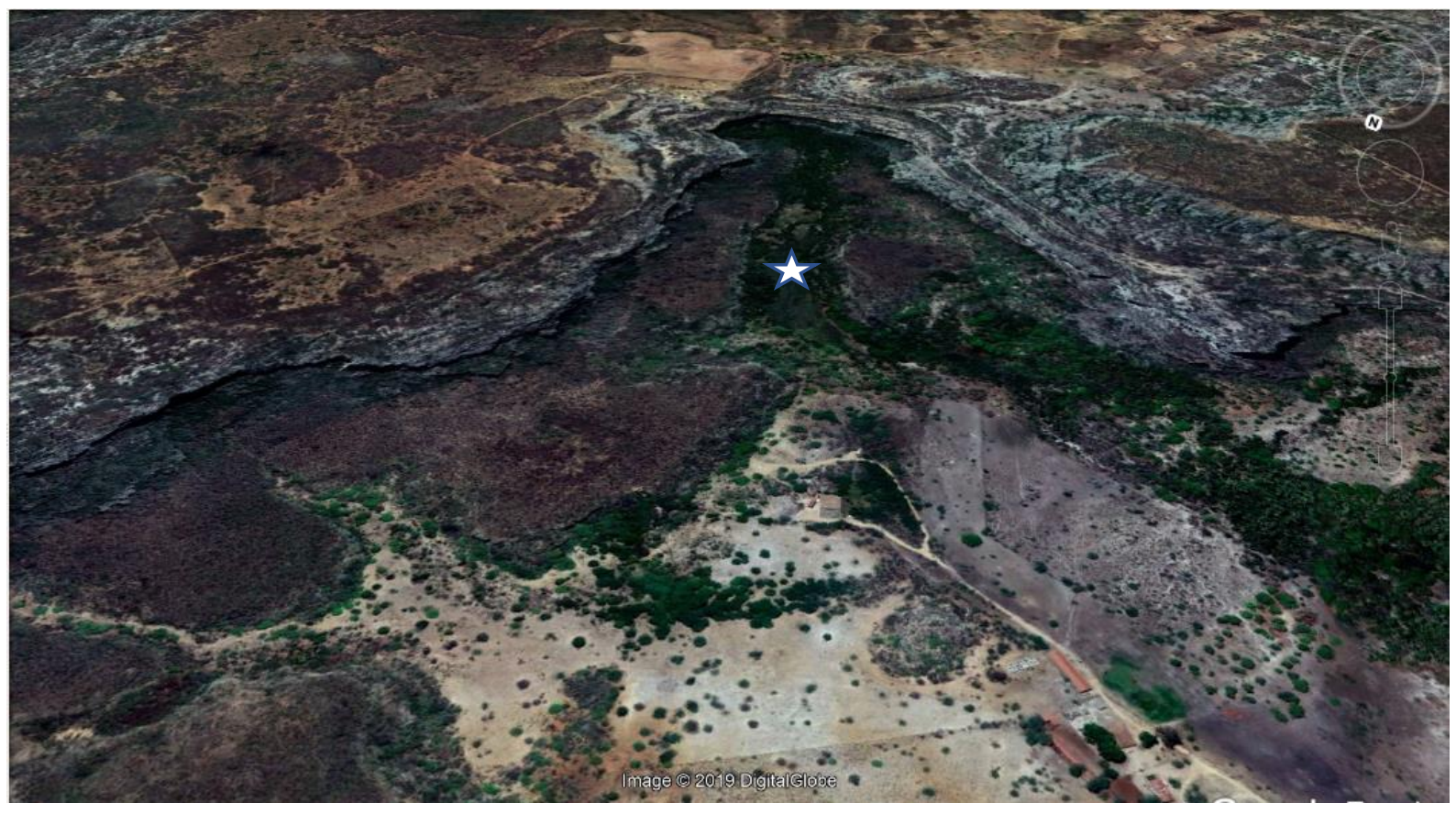

Figura 56. Imagem de satélite da turfeira localizada no Vale do Catimbau, inserida dentro de um anfiteatro rochoso, no meio da Serra de São José. Percebe-se uma camada de umidade no sopé da serra, margeando a caatinga. A estrela sinaliza o local da amostragem. Imagem obtida de Google Earth., em 04/02/2018.

Entre ca. 9.100 e 6.000 anos cal. AP, houve um aumento no número de táxons presentes nos sedimentos, sem, entretanto, haver elevação nas quantidades de concentração, acompanhado da diminuição gradativa da quantidade de areia nos sedimentos, que foi substituída por silte e argila. A floresta se instalou na região, com a presença inclusive de palmeiras, com ervas terrestres e aquáticas, além de algas. Entre os elementos arbóreos presentes neste momento, destacam-se várias árvores que não são comumente encontradas na caatinga, tais como Agarista - Mata Atlântica (Cabral et al., 2013; Reflora, 2019), Alchornea - floresta tropical (Marchant and Hooghiemstra, 2004), Cybianthus - Mata Atlântica (Jung-Mendaçolli et al., 2010), Lecythis - Amazonas, Cerrado e Mata Atlântica (Reflora, 2019) (Anexo 4). Esta diversidade de elementos tradicionais de outros habitats demonstra a ocorrência de uma floresta mais úmida que a vegetação atual, fato corroborado por baixa concentração de micropartículas carbonizadas. Por outro lado, o pico de grãos quebrados de $5.000 / \mathrm{cm}^{3}$, revela a ocorrência de momentos secos, onde os sedimentos devem ter ficado expostos (Campbell, 1991).

- O registro polínico do médio Holoceno da região de São João do Cariri, mostra o domínio das ervas terrestres em detrimento dos elementos arbóreos, com 
distribuição praticamente constante ao longo de todo o perfil estudado. No entanto, as taxas de concentração revelam alterações na fisionomia vegetal, ora com expansão florestal, ora com retração. Apesar do domínio dos elementos herbáceos ser perceptível, nestes também é notada a alternância em sua representatividade. Esta configuração, que indica uma região constantemente úmida, pode ser explicada pelo relevo local, uma vez que o ponto de coleta se encontra muito próximo à rede de drenagem principal local (Figura 57). Além disso, a fisionomia da região sugere uma lagoa (Figura 58), talvez inserida em depressão da rocha cristalina, pois no local amostrado há matacões que circundam toda a área.

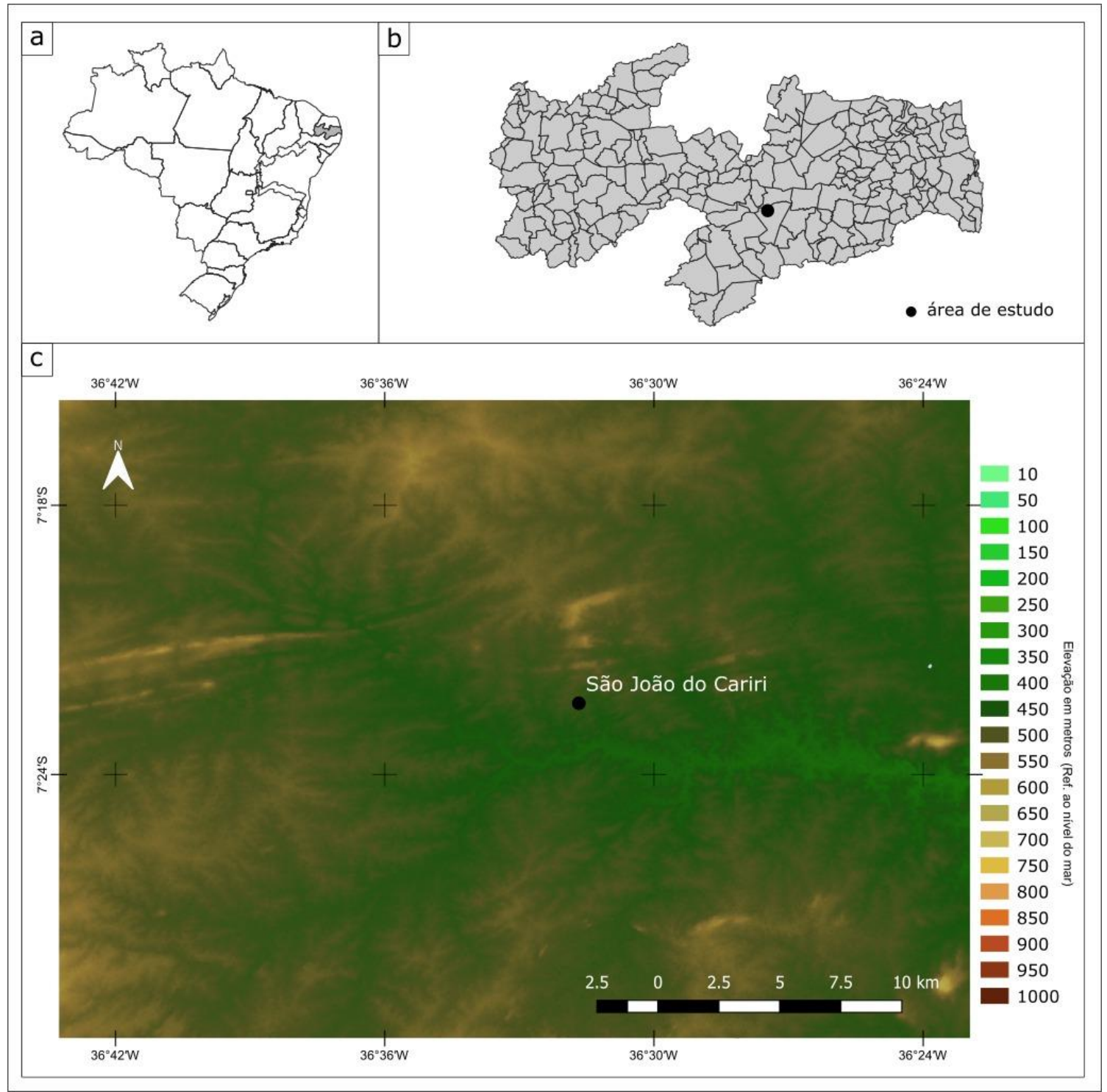

Figura 57. Mapa de relevo da região da Bacia Escola, com a localização do ponto de coleta. a) Mapa do Brasil com a indicação do estado da Paraíba; b) Mapa da Paraíba, com indicação do município de São João do Cariri; c) Indicação do ponto de coleta, próximo à rede de drenagem. 
Entre ca. 6.200 e 5.500 anos cal. AP, prevaleceram árvores e arbustos cuja distribuição atual ocorre em todos os ecossistemas brasileiros, tais como Mimosa, Moraceae, Peltogyne, Sapium e Sloanea (Reflora, 2019), assim como Arecaceae, geralmente encontrada em regiões com climas úmidos (Lorenzi, 1992) e o táxon preferencialmente típico do cerrado Caryocar (Lorenzi, 1992). Outras categorias, também indicativas de ambiente úmido, que prevaleceram foram a das ervas aquáticas, com predomínio de Cyperaceae, as algas Botryococcus, Coelastrum e Zygnema, além de Azolla, que sugerem a presença de um lago na região, similar a florestas de galeria descritas para o cerrado (Ledru et al., 1998, 2007).

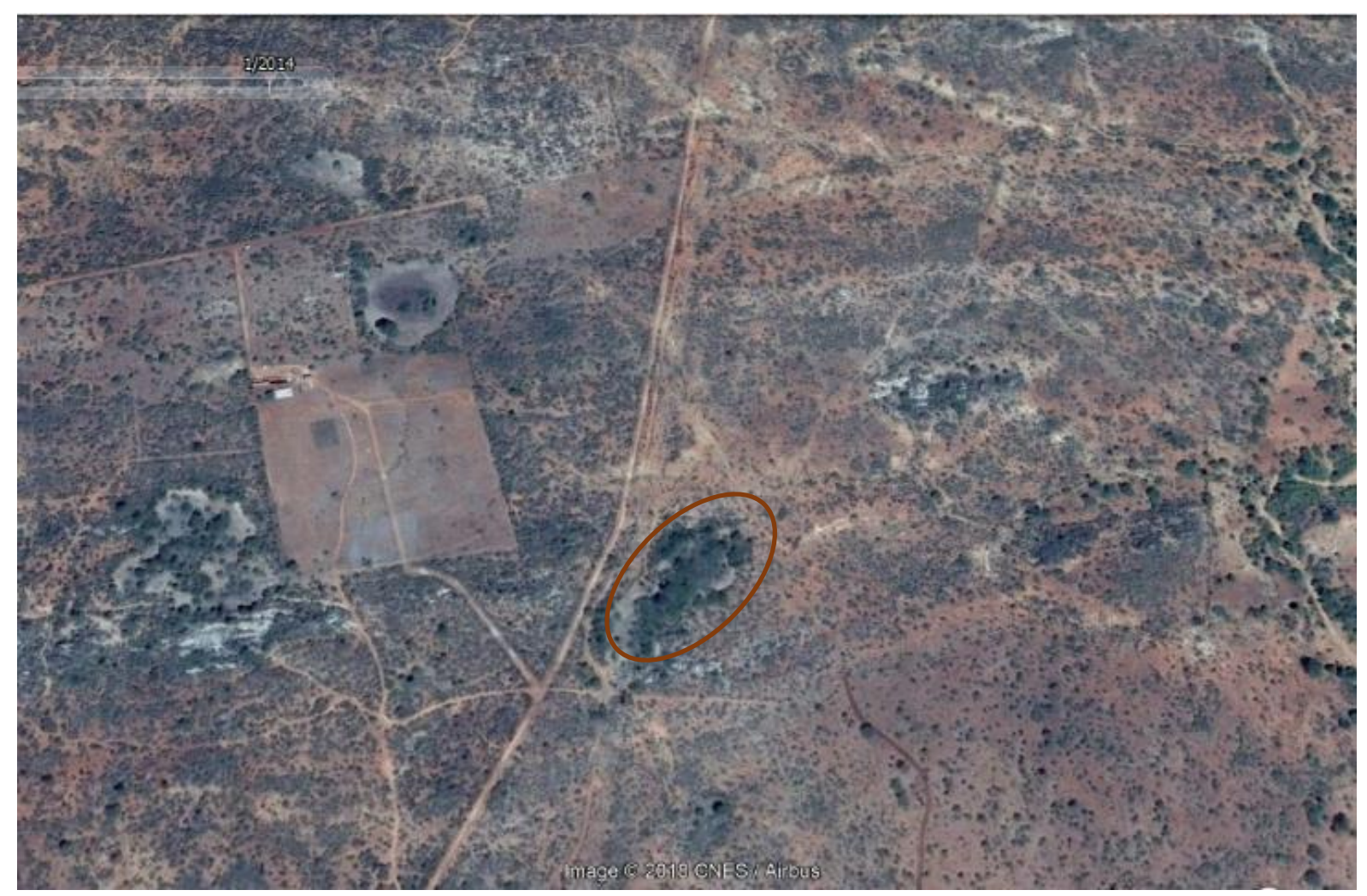

Figura 58. Imagem de satélite com a demarcação do ponto de coleta, em formato de lagoa. Dado referente a 2014. Fonte Google Earth. Acesso: 21/01/2019.

A partir de ca. 4.900 anos cal. AP, é notável a perda de umidade, interpretada como o período da implantação da Caatinga em decorrência da instalação de clima seco (De Oliveira et al., 1999; Cruz et al., 2009; Mendes, 2016), aqui demarcada pela presença de Licania (Oiticica), nativa da região (Beltrão e Oliveira, 2007) e Anacardiaceae, família que tem uma espécie (Apterokarpos) nativa e endêmica da Caatinga (Reflora, 2019). Esta perda de umidade é representada pelo declínio nos 
dados de concentração de todos os elementos. $A$ umidade retorna à região a partir de ca. 2.100 anos cal. AP, com a elevação das concentrações de ervas terrestres e aquáticas, pteridófitas e algas. No entanto, oscilações abruptas ocorreram até aproximadamente 1.615 anos cal. AP, a partir de quando ocorre a estabilização da vegetação de forma geral e se inicia um aumento na quantidade de elementos arbóreos, que atingem seu maior pico, com 1639 grãos $/ \mathrm{cm}^{3}$ a aproximadamente 293 anos AP (idade interpolada). Este aumento é acompanhado pelo incremento dos elementos herbáceos (terrestre e aquáticos) e das algas. Após 500 anos AP (idade interpolada) surge no registro polínico grãos de Pinus e Prosopis (algaroba) elementos introduzidos, que denotam antropização na área de estudo.

Assim como em São João do Cariri, apesar dos $505 \mathrm{~km}$ de distância entre os dois municípios, em Afrânio a partir do final do Holoceno Médio ocorreram grandes oscilações na vegetação, com aumento e diminuição nos valores de porcentagem e de concentração, em todas as categorias, provavelmente em decorrência do período de implantação da caatinga. A partir de ca. 2.200 anos cal. AP ocorreu uma elevação generalizada das concentrações, com domínio de Piperaceae e Virola entre as árvores, Apocynaceae, Araceae e Poaceae entre as ervas terrestres e Cyperaceae e Azolla como representantes de umidade. Neste período surgiram as lianas, que muitas vezes agem como pioneiras (Schnitzer e Carson, 2001). Dentre todos os locais estudados, Afrânio foi o que apresentou menos elementos alóctones e entre eles se destacam Caryocar - cerrado (Reflora, 2019), Faramea - cerrado, Mata Atlântica e caatinga (Reflora, 2019) e Spathiphyllum. De forma geral, a vegetação nesta localidade se estabeleceu, após os ca. 2.000 anos cal. AP com elementos que são comuns na caatinga (Anexo 4).

São Bento do Una e o Vale do Catimbau, distantes $91 \mathrm{~km}$ entre si, apresentam similaridades em termos de sedimentação e consequente recuperação de grãos de pólen. As duas localidades têm baixa deposição de grãos de pólen no Holoceno Médio e a assinatura polínica retorna somente por volta de 1.700 anos cal. AP para o Vale do Catimbau e 1.300 anos para São Bento do Una.

No Vale do Catimbau, a tendência geral de condições secas está bem representada pelos valores de concentração de táxons ecologicamente importantes, indicativos de eventos sucessionais, que prosperam em nichos abertos, tais como Cecropia (Lorenzi, 1998) que teve aumento em sua representação, passando de 743 $\mathrm{g} / \mathrm{cm}^{3}$ no início da zona CA-2 para $22.713 \mathrm{~g} / \mathrm{cm}^{3}$ no final desse intervalo, 
concomitantemente com Melastomataceae, que variou de 741 para $13.421 \mathrm{~g} / \mathrm{cm}^{3}$. Também significativo foi o declínio de Myrtaceae, restrito a apenas uma ocorrência, com $216 \mathrm{~g} / \mathrm{cm}^{3}$. Depois de ca. 500 anos A.P., em direção aos tempos modernos, o sinal polínico apresenta uma diminuição gradual nos táxons adaptados a altos níveis de umidade, como ervas aquáticas e algas, assim como alguns elementos arbóreos que desaparecem da paisagem (Byrsonima, Myrtaceae e Piptadenia). Este padrão climático semiárido também está presente no registro de Icatu, onde foi detectado um declínio no componente arbóreo (De Oliveira et al., 1999).

Em São Bento do Una, a partir de 1.365 anos cal. AP ocorre a recomposição da floresta, com predomínio de Mimosa, com $1.431 \mathrm{grãos} / \mathrm{cm}^{3}$, no entanto, elementos de climas mais frios e úmidos, como Podocarpus, llex e Hedyosmum não estão mais presentes. A umidade atual é percebida pela presença de Borreria e Azolla.

\subsubsection{Diatomáceas e espículas de esponjas}

Apesar da impossibilidade de obter dados quantitativos das frústulas de diatomáceas, devido ao número insuficiente destas nas lâminas, alguns táxons foram identificados (Tabela 10), apesar do estado geral de dissolução em que se encontrava a maioria das frústulas. Tanto em Afrânio como em São Bento do Una, foi localizada Cyclotella, um gênero de diatomáceas planctônicas, geralmente de águas paradas e/ou de considerável coluna d'água (Germain, 1981; Moro e Fürstenberger, 1997), condizente com os ambientes descritos pelos resultados palinológicos para estas localidades. As demais espécies identificadas são perifíticas, ou seja, vivem aderidas a um substrato e determinam a existência de acúmulo de água nas regiões estudadas. Mesmo com a impossibilidade de obter maiores informações, devido à indefinição quanto à espécie e à distribuição destes elementos ao longo das colunas sedimentares, a presença do grande número de diatomáceas dissolvidas e/ou quebradas, podem ser indicativas de alteração de pH alcalino da água (Jorgensen, 1955), ou transporte de alta energia (Tibby, 2001), respectivamente. O transporte de alta energia é justificado para as regiões estudadas, onde alterações climáticas abruptas promovem chuvas torrenciais (Mendes, 2016).

Espículas de esponjas foram encontradas tanto nas lâminas preparadas para diatomáceas, quanto para as de fitólitos, geralmente quebradas. A ocorrência destes organismos aquáticos corrobora a presença de clima úmido na região da caatinga em 
épocas anteriores ao presente, com a ocorrência de elementos florestais característicos de ecossistemas disjuntos.

Tabela 10. Distribuição dos táxons de diatomáceas identificados em cada localidade de estudo.

\begin{tabular}{|l|c|c|c|c|}
\hline Táxon & São Bento do Una & Afrânio & São João do Cariri & Habitat \\
\hline Achnantes & $\mathrm{X}$ & & & perífitica \\
\hline Amphora & & $\mathrm{X}$ & & perifítica \\
\hline Craticula & $\mathrm{X}$ & & $\mathrm{X}$ & perífitica \\
\hline Cyclotella & $\mathrm{X}$ & $\mathrm{X}$ & & planctônica \\
\hline Cymbella & & $\mathrm{X}$ & & perífitica \\
\hline Eunotia & $\mathrm{X}$ & $\mathrm{X}$ & & perífitica \\
\hline Gomphonema & $\mathrm{X}$ & & & perífitica \\
\hline Luticola & $\mathrm{X}$ & $\mathrm{X}$ & $\mathrm{X}$ & perífitica \\
\hline Navicula & & $\mathrm{X}$ & $\mathrm{X}$ & perífitica \\
\hline Pinnularia & $\mathrm{X}$ & & $\mathrm{X}$ & perífitica \\
\hline Rhopalodia & $\mathrm{X}$ & & $\mathrm{X}$ & perífitica \\
\hline Stauroneis & & & $\mathrm{X}$ & perífífica \\
\hline Synedra & & & & \\
\hline
\end{tabular}

\subsubsection{Fitólitos}

Os fitólitos analisados no perfil sedimentar de São Bento do Una corroboram a ocorrência de floresta úmida para a região no período entre 34.935 e 9.673 anos cal. $\mathrm{AP}$, devido à presença de elementos arbóreos em sincronia com palmeiras, gramíneas C3 bambusóides e panicóides. A frequência de bambusóides, diagnósticos de ambientes florestados (Iriarte and Paz, 2009), variando entre 10\% e 25\% se assemelha à floresta de bambus caracterizada por Watling et al. (2016) no Acre, onde fitólitos de táxons bambusóides obtiveram a soma de 15\%. Somado a isto, a alta frequência de panicóides, geralmente adaptados a terras inundadas (Iriarte and Paz, 2009) por volta de 37\%, reafirma a ocorrência de um ambiente bem mais úmido do que $o$ atual na caatinga moderna.

Entre 9.673 anos cal. AP e 1.365 anos cal. AP ocorre oscilação na soma total de elementos arbóreos, com a ausência de palmeiras e com a diminuição de gramíneas panicóides, em sincronia com os resultados palinológicos, que apresentaram baixa diversidade para o local, tendo sido sugerido a ocorrência de eventos chuvosos de alta energia (Mendes, 2016), que teriam impedido a deposição/conservação de microfósseis. 
A partir de 1.362 anos cal. AP, a configuração da vegetação apresenta nova característica, uma vez que as palmeiras diminuem a ca. $4 \%$, acompanhados pelo declínio de bambusóide de $32 \%$ para 13\%. No entanto, as gramíneas panicóides se mantém na casa dos $32 \%$, indicando clima um pouco menos úmido para a região.

\subsection{Fisionomia da vegetação e sua relação com as variações climáticas} do Pleistoceno Tardio e Holoceno

\subsubsection{Pleistoceno Tardio - Transição Pleistoceno/Holoceno}

Durante o Pleistoceno Tardio, caracterizado por eventos climáticos abruptos de frio extremo no Hemisfério Norte (HN) dentro do período glacial (Heinrich, 1988), o clima e a vegetação do NEB passaram por grandes transformações (De Oliveira et al., 1999; Behling et al., 2000; Auler et al., 2004; Cristalli, 2006; Wang et al., 2006; Cruz et al., 2009; Pessenda et al., 2010; Cheng et al., 2013; Barreto, 2016). A presença de floresta característica de clima frio e úmido a partir de ca. 35.000 anos cal. AP, no município de São Bento do Una - PE, dentro do atual domínio da caatinga é um exemplo destas transformações.

A presença de Podocarpus associado a Hedyosmum, elementos característicos de floresta montana, de clima úmido, em sintonia com vegetais característicos de Mata Atlântica e de Floresta Amazônica, neste perfil sedimentar descontínuo, com idades entre 34.935 anos cal. AP e ca. 19.000 cal. AP, engloba os eventos Heinrich 3 e 2, além do UMG, quando a pluviosidade na região seguia padrões de distribuição diferentes dos atuais ( Wang et al., 2004; Cruz et al., 2009; Cheng et al., 2013; Barreto, 2016, entre outros). Estas fases pluviais são amplamente apoiadas para o NEB e foram descritas para o norte da Bahia através da datação de depósitos de travertino e isótopos de espeleotemas para o evento $\mathrm{H} 4$ e $\mathrm{H} 1$ (Wang et al., 2004), enquanto para a Chapada Diamantina (sul da Bahia) isótopos de espeleotemas registram eventos pluviais nos eventos $\mathrm{H} 4, \mathrm{H} 3$ e H2, sendo o $\mathrm{H} 3$ mais moderado que os demais (Barreto, 2016). Já no Rio Grande do Norte, extremo norte do NEB, os isótopos de espeleotemas revelam aumento de pluviosidade nos eventos H2 e H1, com diminuição dos eventos úmidos no UMG (Cruz et al., 2009). Por outro lado, isótopos de $\delta^{13} \mathrm{C}$ em solos dos estados do Ceará, Paraíba e Piauí identificaram a predominância de vegetação arbórea, vinculada a maior umidade a partir de 18.000 anos até a transição Pleistoceno/Holoceno (Pessenda et al., 2010a). 
Sedimentos marinhos coletados próximo ao município de Fortaleza - $\mathrm{CE}$, mostram aumento na concentração e influxo polínico em 40.000, 33.000 e 24.000 anos AP, com taxas ainda mais elevadas entre 15.500 e 11.800 anos AP (Behling et al., 2000). É interessante ressaltar a presença de Hedyosmum e Drymis neste trabalho, uma vez que estes dois elementos vegetais são comumente associados a florestas de Araucaria e Podocarpus.

\subsubsection{Holoceno inicial}

O início do Holoceno é caracterizado por um evento que ocorre tanto nos sedimentos de São Bento do Una como nos de Afrânio, onde uma camada de areia grossa foi depositada e a recuperação de palinomorfos é pouco significativa. Esta camada de areia pode ser interpretada como decorrente de episódio pluvial, ocorrido provavelmente durante o evento climático 8.2, de alta precipitação, de acordo com 0 modelo climático Syntrace (Nace et al., 2014).

A partir de ca. 10.900 anos cal. AP até aproximadamente 6.000 anos cal. AP, a fisionomia vegetacional do NEB é característica de floresta tropical e/ou cerrado e/ou floresta de galeria, de acordo com a localização geográfica do ponto de coleta. Os sedimentos de Afrânio e do Vale do Catimbau - PE, distantes $411 \mathrm{~km}$ entre si, apresentam características de umidade em comum, com vegetação relativamente similar, composta por palmeiras e ervas aquáticas, no entanto, o Vale do Catimbau apresenta uma configuração geológica diferenciada, com a presença de falhas que permitem o acesso às águas subterrâneas (Gomes, 1995), que acarreta em um sinal polínico distinto da vegetação que circunda a turfeira, sem sinal da caatinga, com excessão do gênero Ziziphus. Já em Afrânio, a vegetação úmida apresenta palmeiras e elementos da Mata Atlântica e da Amazônia, assim como táxons característicos do ecossistema caatinga. Este período úmido no início do Holoceno é corroborado pelo registro do Icatu, na Bahia, onde registro palinológico identifica vegetação arbórea montana, composta com elementos atlânticos e amazônicos. O modelo Syntrace (Nace et al., 2014) delimita, dentro do Holoceno, o período entre ca. 9.000 e 8.000 anos AP, como o mais úmido do período, corroborado por isótopos do RN (Cruz et al., 2009), que também sugere grande umidade a 8.000 anos AP. Estes eventos de umidade neste período podem estar relacionados ao evento climático 8.2 (Bond et al., 1997), como também inferido nas cavernas Paixão e do Padre (BA), por isótopos de espeleotemas (Cheng et al., 2009). Isótopos de Carbono de sedimentos do NEB, 
sugerem que a partir de 10.000 os elementos florestais começam a diminuir e elementos de cerrado começam a dominar (Pessenda et al., 2010a).

\subsubsection{Holoceno médio a tardio}

A partir de ca. 6.000 anos cal. AP a assinatura polínica se altera em todos os perfis analisados. No perfil do Vale do Catimbau, a idade dos sedimentos passa de 6.440 anos cal. AP a $120 \mathrm{~cm}$ para 1.714 anos cal. AP a $110 \mathrm{~cm}$ de profundidade. Ocorrência similar é percebida em São Bento do Una, que na camada de areia descrita acima, só foi possível a coleta de três amostras um pouco mais orgânicas entre a areia, as quais continham pouca matéria orgânica e, consequentemente, baixa diversidade e quantidade polínica. As idades radiocarbônicas obtidas passaram de 9.673 anos cal. AP, para 1.365 anos cal. AP após a camada de areia.

Em São João do Cariri - PB, ocorrem elementos de cerrado, com fisionomia de mata de galeria e presença de palmeiras de 6.000 anos cal. AP a 5.000 anos cal. AP e a partir de 4.900 anos cal. AP tem início um período de ressecamento, com a diminuição dos táxons florestais e o predomínio de táxons da caatinga. Em Afrânio PE, a partir de ca. 6.000 anos cal. AP ocorrem oscilações constantes de aumento e diminuição de todos os táxons, com a menor concentração de arbóreos e de elementos aquáticos do perfil, até ca. 2.500 anos cal. AP. Este cenário de ressecamento, apresentado a partir do meio do Holoceno médio até ca. de 2.000 anos AP, é condizente com o registro polínico do Icatu (De Oliveira et al., 1999) e do Ceará (Montade et al., 2014), com o modelo climático Syntrace (Nace et al., 2014), com isótopos do RN (Cruz et al., 2009) e com isótopos de Carbono do NEB (Pessenda et al., 2010a) e é compreendido como o período de implantação da caatinga no NEB a partir de 4.900 anos AP.

Já no meio do Holoceno Tardio, por volta de 2.000 anos AP, os registros palinológicos apresentam uma nova fisionomia vegetal, com características um pouco mais úmida, com o retorno da deposição tanto no Vale do Catimbau quanto em São Bento do Una. O hiato de sedimentação do Vale do Catimbau, com o retorno da deposição de sedimentos em uma camada com inversão de idades, associado à camada de areia de $70 \mathrm{~cm}$, pode ser interpretado como um momento de chuvas torrenciais, que teriam ocorrido a ca. de 2.000 - 1.500 anos AP, reconhecidos por Viana et al., (2014) e por Mendes (2016) como período de instabilidade climática, com a predominância de temporais de alta energia. Isótótopos de espeleotemas da BA 
corroboram com período úmido para este período (Novello et al., 2012). A partir deste período, ocorre a estabilização da vegetação relativamente com os padrões atuais. Devido à falta de resolução da amostragem, uma vez que os perfis foram escavados em trincheiras muitas vezes ressequidas, não foi possível a correlação exata com eventos climáticos ocorridos ao longo do tempo.

\subsection{Micropaleontologia de cálculos dentários de Stegomastodon}

Estudos têm sido realizados ao longo de décadas para caracterizar a dieta de animais atuais e da megafauna, com a utilização de isótopos de Carbono, Oxigênio e Nitrogênio (DeNiro e Epstein, 1978; Schoeninger e DeNiro, 1984; Cerling et al., 1993, 1999; Macfadden, 2000; Sánchez et al., 2004; Silva, 2008; Viana et al., 2011; Dantas et al., 2013; França et al., 2014 entre outros). Para Stegomastodon, foi determinado o hábito alimentar deste gênero da megafauna, assim como o hábitat em que os animais viviam e o consenso a que muitos destes autores chegaram é de que este animal apresenta uma tendência generalista e oportunista. Desta forma, sua dieta inclui plantas C3, C4 ou a mistura entre elas (Cerling et al., 1999; Sánchez et al., 2004; Dantas et al., 2013a; França et al., 2014). No entanto, para a região do NEB, a caracterização da dieta geralmente tende à pastadores de gramíneas C4 (Silva, 2009; Viana et al., 2011; Dantas et al., 2013b; França et al., 2014), passando a generalistas C3/C4 no sul da Bahia (Sánchez et al., 2004) e de forma geral, o ambiente é interpretado como savana aberta ou campo.

Entretanto, os resultados obtidos na análise de cálculos dentários pertencentes a animais deste gênero, todos coletados no estado de Pernambuco, conforme tabela 7, caracterizam uma dieta alimentar baseada em elementos vegetais de uma floresta alta, composta por árvores, arbustos e ervas com ciclo fotossintético C3, que apresentavam ao menos três andares de dossel, além de gramíneas C4 e ervas aquáticas (Tabela 9), com elementos característicos da Mata Atlântica, como por exemplo Podocarpus (Lorenzi, 1992, 2009; Garcia, 2003; Mofatto, 2005; Reflora, 2019). Desta forma, estes resultados palinológicos obtidos a partir da análise de cálculos dentários de Stegomastodon apoiam a conclusão de Dantas et al. (2013) de que resultados de isótopos destes animais não são bons indicadores de vegetação aberta, uma vez que eles se alimentavam do que estivesse à disposição.

Esta configuração vegetacional, no estado de Pernambuco, se opõe à distribuição regional realizada por França et al. $(2014,2015)$, a qual sugere que estes 
animais que viviam entre $6^{\circ} \mathrm{S}$ e $10^{\circ} \mathrm{S}$ de latitude mantinham dieta à base de gramíneas C4 e é apoiada por estudo realizado por Mothé et al. (2010), que relaciona a forma de vida de Stegomastodon à dos elefantes atuais e Cerling et al. (1999) que ressalta o fato de que estes animais modernos da savana apresentam predominantemente dieta mista entre C3 e C4. Além disso, Cerling e Harris (1999) sugerem a possibilidade do uso de isótopos de Carbono de esmalte de dentes poderem ser utilizados para determinar a composição isotópica da atmosfera passada, uma vez que o enriquecimento isotópico entre a vegetação e o esmalte é de $14.1 \pm 0,5 \%$. Assim, os dados palinológicos de cálculos dentários e de sedimentos, devidamente datados, são importantes para fazer esta calibração.

\subsection{Integração de dados micropaleontológicos e paleontológicos}

A presença de microfósseis pertencentes a táxons adaptados a clima úmido e frio no perfil sedimentar de São Bento do Una - PE, não análogos à vegetação atual, entre 34.935 anos cal. AP e cerca de 19.000 anos cal. AP, assim como nos cálculos dentários de Stegomastodon, permite afirmar que a megafauna presente nessa localidade do NEB, durante o Pleistoceno Tardio, viveu em paisagem composta por floresta tropical úmida e relativamente fria, com alta diversidade, um ambiente muito diferente do que aquele presente no ecossistema da caatinga moderna (Figura 59).

Esta configuração climática pode, inclusive, ter sido facilitadora de migrações bióticas, através da formação de corredores de umidade, pelos quais táxons amazônicos e atlânticos chegaram à região onde hoje está estabelecida a vegetação de caatinga. Neste caso, pode-se citar o táxon arbóreo Podocarpus, que atualmente está presente em florestas de regiões alto-montanas do sudeste do Brasil em altas elevações ou em baixas elevações de altas latitudes na Região Sul, junto a florestas de Araucária (De Oliveira, 1992; De Oliveira et al., 2005; Pessenda et al., 2009). A expansão de florestas úmidas em áreas da atual vegetação semi-árida do NEB é evidenciada pela presença de megafósseis vegetais em tufos calcários depositados por volta de 17.000 anos cal. AP (Cristalli, 2006) e por dados palinológicos da transição Pleistoceno/Holoceno no atual campo de dunas do médio Rio São Francisco (De Oliveira et al., 1999). Em ambas localidades, os fósseis apontam para florestas úmidas e relativamente frias para os estágios finais da última glaciação.

Dessa forma, Podocarpus pode ter expandido sua área de abrangência no início do último ciclo glacial, ou mesmo anterior a isto, quando condições climáticas 
mais frias e úmidas (Wang et al., 2004; Cruz et al., 2009; Barreto, 2016) permitiram o seu estabelecimento em baixas latitudes sob climas mais frios que o atual. Stute et al. (1995) reportaram, a partir da distribuição de gases raros em água de aquíferos profundos no NEB, a diminuição de aproximadamente $5^{\circ} \mathrm{C}$ em média na temperatura anual da atual área de caatinga semi-árida, durante o UMG. A existência de vegetação florestal pleistocena no setor semi-árido da Bahia é também apoiada pela descoberta de um esqueleto completo de um primata pertencente à megafauna, em uma caverna na região da caatinga atual, na Bahia (Cartelle and Hartwig, 1996).

Atualmente, árvores de Podocarpus são encontradas em brejos de altitude na região da caatinga (Andrade-Lima, 1981; Rodal et al., 1998; Sales et al., 1998), os quais são considerados microrefúgios que mantém a temperatura e a umidade adequados à vegetação não análoga àquele ecossistema (Locosselli et al., 2016). Além disso, no NEB, a ocorrência de Podocarpus é registrada no Lago Caçó, no estado do Maranhão, a partir de 13.600 anos AP (Ledru et al., 2001, 2007) e em testemunho marinho coletado na plataforma continental, próximo ao estado do Rio Grande do Norte (Dupont et al., 2009). No entanto, são vários os registros de Podocarpus em florestas de galeria, durante o Pleistoceno Tardio, na região de cerrado moderno do Brasil Central (Ledru et al., 1998, 2016; Salgado-Labouriau et al., 1998; Barberi et al., 2000).

Esta fisionomia vegetal de floresta tropical úmida e fria persiste até ca. 19.000 anos cal. AP, quando Podocarpus e Hedyosmum desaparecem da assinatura polínica de São Bento do Una. No entanto, a floresta se mantém estável na região até aproximadamente 9.600 anos cal. AP. Entretanto, em Afrânio e no Vale do Catimbau - PE, ambos com registros a partir de ca. 11.000 anos cal. AP, uma mistura de elementos, hoje característicos da Mata Atlântica, como por exemplo Agarista; da Floresta Amazônica, como Socratea e Calycophyllum; ou presente em ambas, como Macrolobium, Oreopanax e Sciaphila permaneceram na paisagem, com declínio ao longo do tempo, até ca. 6.000 anos cal. AP. 


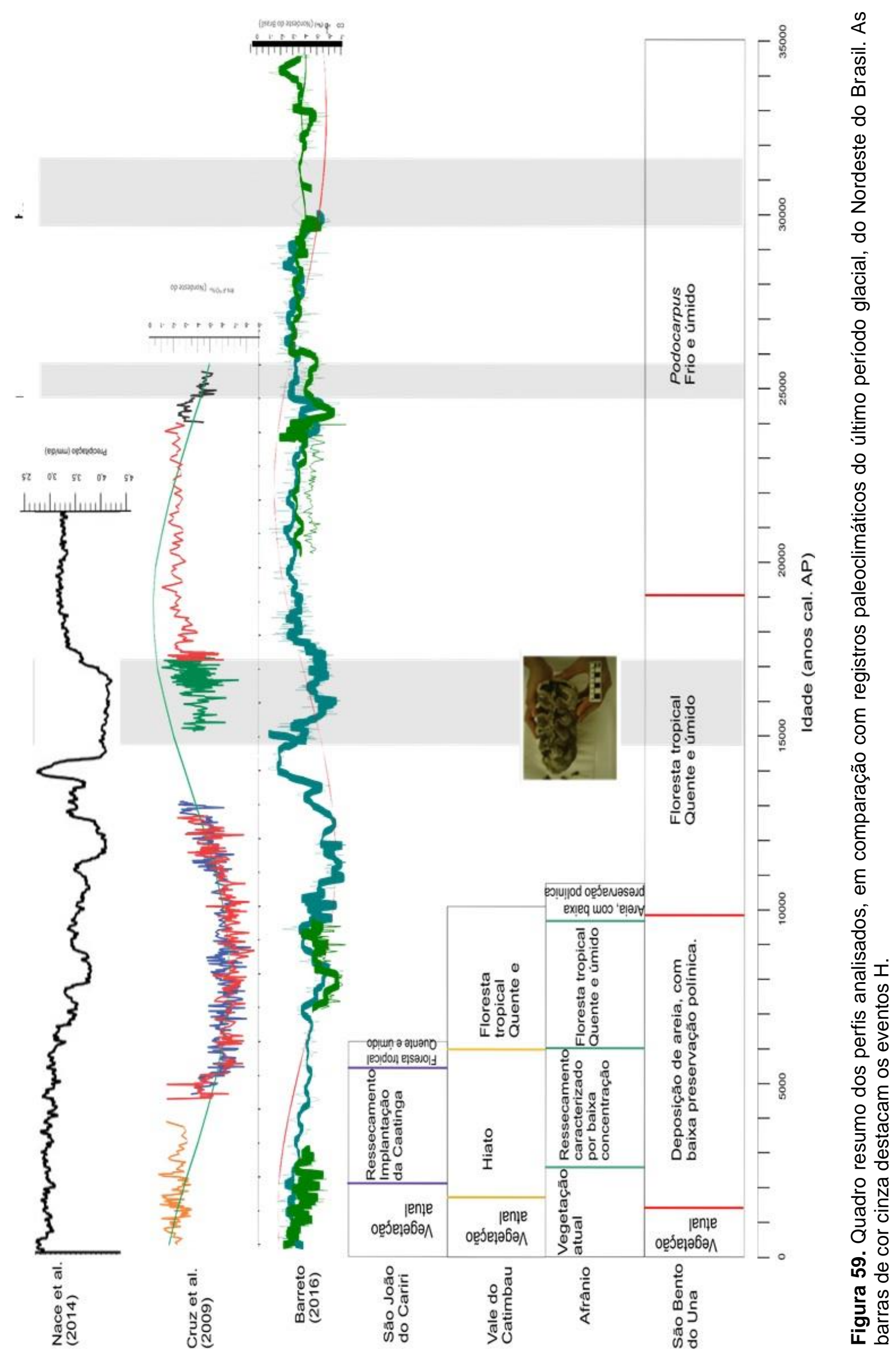


Esta paleopaisagem é também corroborada pelos microfósseis encontrados em cálculos dentários de Stegomastodon, coletados no estado de Pernambuco e pela baixa frequência de grãos de Poaceae, uma vez que esta importante família de ervas terrestres e aquáticas, não ultrapassa $20 \%$ da soma polínica, assim como pela baixa concentração total de partículas carbonizadas, nesta fase, com máximo somente a ca. 9.700 anos cal. AP.

Desta forma, a premissa de que estes animais viviam em ambientes abertos, iguais às savanas africanas (Bergqvist et al., 1997; Silva, 2001; Oliveira, 2012; França et al., 2014, 2015), não é apoiada pelo registro de microfósseis nas áreas de estudo do presente estudo.

Assim, a hipótese de que a vegetação se alterou, durante a transição Pleistoceno/Holoceno para a configuração vegetacional da caatinga atual, devido à seca extrema, o que teria levado os animais à extinção (Silva, 2001; De Vivo and Carmignotto, 2004), também não é apoiada pelo registro micropaleontológico.

A partir dos dados obtidos, é possível observar a alteração da vegetação nas áreas estudadas devido ao aquecimento gradativo, ocorrido ao final do UMG em conjunto com a alta umidade observada no evento climático $\mathrm{H} 1$ para a região do NEB (Wang et al., 2004; Cruz et al., 2009). Estas mudanças climáticas reduziram a vegetação adaptada a clima mais frio, a refúgios ainda hoje encontrados em brejos de altitude no NEB (Andrade-Lima, 1981; Rodal et al., 1998; Jesus et al., 2005), mas o ambiente florestal permaneceu na região, com outra configuração. Desta forma, o que pode ter ocasionado a extinção da megafauna não teria sido a implantação da caatinga, mas sim a não adaptação ao clima quente e extremamente úmido deste período e o surgimento de vegetação sem correspondentes modernos, ou seja, vegetação não-análoga. Esta hipótese é apoiada por Raczka et al. (2018), que determinou com a utilização de esporos de Sporormiella em sedimentos lacustres da região de Lagoa Santa - MG, o início do declínio de animais da megafauna a partir de 18.000 anos AP, com a extinção de fato tendo ocorrido a ca. de 12.000 anos AP.

Esporos de Sporormiella, geralmente usados para inferir a presença e abundância de grandes mamíferos herbívoros (Gill, 2014; Raczka et al., 2016, 2018), não foram encontrados nos sedimentos analisados. De forma geral, estes esporos são localizados em análises palinológicas em sedimentos orgânicos de origem lacustre (Davis, 1987; Davis e Shafer, 2006; Gill, 2014; Raczka et al., 2016, 2018), totalmente diferenciados dos sedimentos arenosos encontrados em São Bento do Una - PE. 
Devido à composição dos sedimentos estudados, é possível que estes esporos não tenham sido preservados.

Em relação à dieta dos animais da megafauna, a predominância de gramíneas C4, geralmente atribuída para estes mamíferos (Silva, 2009; Viana et al., 2011; Dantas et al., 2013b; França et al., 2014), para a região da caatinga, não encontra apoio, uma vez que o sinal polínico e de fitólitos encontrados nos sedimentos contemporâneos à megafauna, assim como nos cálculos dentários de dentes fósseis destes animais, indicam a predominância de vegetação com ciclo fotossintético C3.

A fase de ressecamento ocorrida a partir de $\sim 5.500$ anos cal. AP, é notada em todos os perfis analisados e coincide com os resultados paleoclimáticos anteriormente citados e com o evento arqueológico denominado Hiato do Arcaico (Araujo et al., 2005), que sugere que eventos climáticos secos foram responsáveis pela migração de grupos humanos durante o Holoceno médio. 


\section{CONCLUSÕES}

Os resultados palinológicos, tanto de sedimentos quanto dos cálculos dentários de Stegomastodon, evidenciam que os megamamíferos pleistocênicos que viveram na caatinga, habitaram um ambiente com clima e vegetação característicos de floresta tropical úmida, com temperatura mais amena, com redução de no mínimo 5ํ․

As alterações climáticas de esfriamento do Hemisfério Norte, ocorridas durante o Pleistoceno Tardio (eventos Heinrich), alteraram a vegetação do NEB, devido a aumentos de precipitação, mas a fisionomia da caatinga, tal qual é hoje, só se estabeleceu por volta de 4.900 anos cal. AP. Desta forma, é possível afirmar que a extinção da megafauna, que teve início a 18.000 anos cal. AP, no período úmido (Raczka et al., 2018), não ocorreu, nesta região do NEB, devido à troca da fisionomia vegetal para a da caatinga atual, uma vez que esta só se instalou após 5.000 anos. Desta forma, a extinção pode ter ocorrido devido à não adaptação destes animais a temperaturas e precipitações elevadas.

De forma geral, é possível sugerir a presença de mosaicos na vegetação da região estudada, desde o Pleistoceno até os dias atuais, com a presença de elementos hoje característicos de florestas tropicais úmidas, do cerrado e da própria caatinga. As alterações das condições climáticas podem ter possibilitado a instalação de corredores bióticos que teriam permitido a expansão da área de dominância destes ecossistemas e, portanto, a ocorrência desta vegetação não-análoga.

Não foi possível determinar se houve influência humana na extinção da megafauna, apesar de haver indícios da presença humana, em municípios de Pernambuco (Etchevarne, 2000; Martin, 2005), uma vez que as concentrações totais de micropartículas de carvão se mantiveram abaixo de $10.000 / \mathrm{cm}^{3}$, no período correspondente a 12.000 anos cal. AP, quando teria ocorrido o evento, no entanto, é possível imaginar que o homem tenha causado stress ecológico a uma população que já se achava diminuída, devido às alterações climáticas.

Devido à presença de elementos vegetacionais característicos da Mata Atlântica e da Floresta Amazônica nos sedimentos, é possível sugerir a existência de corredores bióticos, em épocas de maior umidade, que teriam possibilitado esta troca florística, a qual é detectada nos dias atuais pela presença destes elementos em brejos de altitude no NEB. Estes corredores podem ter se instalado às margens da rede de drenagem, que durante os eventos Heinrich, se tornaram caudalosos e 
perenes devido ao aumento de precipitação, como ocorrido na Bacia Hidrográfica do Rio Parnaíba - PI. O sinal polínico do Icatu reforça a presença destes corredores, uma vez que também apresenta elementos de clima mais frio e úmido na caatinga bahiana.

As alterações vegetacionais, com a alternância entre elementos florestais adaptados a clima úmido e frio, aqueles típicos de floresta tropical e os da caatinga atual, ao longo do Pleistoceno Tardio até o Holoceno, estão em sincronia com os eventos climáticos registrados para a região do NEB, tais como os eventos Heinrich, Younger Dryas e Bond.

A vegetação presente em regiões onde hoje predomina o agreste e sertão dos estados de Pernambuco e Paraíba, apresentava fisionomia florestal, durante 0 Pleistoceno Tardio e, desta forma, é possível afirmar que animais generalistas da megafauna tinham hábitos alimentares relacionados a plantas de ciclo fotossintético C3, principalmente os do gênero Stegomastodon, que se alimentavam com frutas, ramos, folhas e cascas de árvore, além das gramíneas.

Em síntese, este estudo traz uma significativa contribuição ao entendimento da relação dos animais da megafauna com a paisagem do semi-árido nordestino, que ainda precisa de muitos esclarecimentos. Além disso, ele atesta a viabilidade de estudos palinológicos, seja em sedimentos de lagos efêmeros ou em cacimbas/ tanques com restos destes animais no sertão nordestino, ou ainda em cálculos dentários. 


\section{REFERÊNCIAS BIBLIOGRÁFICAS}

Aguiar, C.M.L., Zanella, F.C.V., Martins, C, F., and Carvalho, C.A.L., 2003, Plantas visitadas por Centris spp. (Hymenoptera: Aidae) na caatinga para obtenção de recursos florais: Neotropical Entolmology, v. 32, p. 247-259.

Aimola, L., and Moura, M., 2016, A Influência da Circulação de Revolvimento Meridional do Atlântico na Definição da Posição Média da ZCIT ao Norte do Equador. Uma Revisão: Revista Brasileira de Meteorologia, v. 31, p. 555-563, doi:10.1590/0102-7786312314b20150059.

Albuquerque, S.G., Soares, J.G.G., and Araújo Filho, J.A., 1982, Densidade de espécies arbóreas e arbustivas em vegetação de caatinga: 16.

Alcoforado-Filho, F.G., Sampaio, E.V.S.B., and Rodal, M.J.N., 2003, Florística e fitossociologia de um remanescente de vegetação caducifólia espinhos arbórea em Caruaru, Pernambuco: Acta bot. bras., v. 17, p. 287-303, doi:10.3109/00016357208997458.

Alroy, J., 2001, A multispecies overkill simulation of the end-Pleistocene megafaunal mass extinction: Science, v. 292, p. 1893-1896, doi:10.1126/science.1059342.

Alvares, C.A., Stape, J.L., Sentelhas, P.C., Gonçalves, J.L.D.M., and Sparovek, G., 2014, Köppen's climate classification map for Brazil: Meteorologische Zeitschrift, v. 22, p. 711-728, doi:10.1127/0941-2948/2013/0507.

Alves, R. da S., 2007, Os mamíferos pleistocênicos de Fazenda Nova, Brejo da Madre de Deus, Pernambuco: aspectos tafonômicos, taxonômicos e paleoambientais: Universidade Federal de Pernambuco, $127 \mathrm{p}$.

Alves, R. da S., and Barreto, A.M.F., 2007, A megafauna pleistocênica de Fazenda Nova, Brejo da Madre de Deus, Pernambuco, Brasil, in Paleontologia: Cenarios de Vida-Paleoclimas-Volume 5, p. 819-826.

Alves, R. da S., Barreto, A.M.F., Borges, L.E.P., and Farias, C.., 2007, Aspectos tafonômicos no depósito de mamíferos pleistocênicos de Brejo da Madre de Deus, Pernambuco: Estudos Geológicos, v. 17.

Amorim, I.L. de, Sampaio, E.V.S.B., and Araújo, E. de L., 2005, Flora e estrutura da vegetação arbustivo-arbórea de uma área de caatinga do Seridó, RN, Brasil: Acta bot. bras., v. 19, p. 615-623, doi:10.1590/S0102-33062005000300023.

Andrade-Lima, D., 1966, Contribuição ao estudo do paralelismo da flora amazônica e nordestina.: 
Andrade-Lima, D., 1982, Dry forest refuges in neotropical Brazil, in Prance, G.T. ed., Biological Diversification in the Tropics, New York, Columbia Univ. Press, p. 245251.

Andrade-Lima, D., 1981, The caatingas dominium: Revista Brasil. Bot., v. 4, p. 149163.

Araújo-Júnior, H.I. de, and Porpino, K.O., 2011, Assembleias fossilíferas de mamíferos do Quaternário do Estado do Rio Grande do Norte, Nordeste do Brasil: diversidade e aspectos tafonômicos e paleoecológicos: Pesquisas em Geociências - UFRGS, v. 38, p. 67-84.

Araujo, A.G.M., Neves, W.A., Piló, L.B., and Atui, J.P. V., 2005, Holocene Dryness and Human Occupation in Brazil During the "Archaic Gap": Quaternary Research, v. 64, p. 298-307, doi:10.1016/j.yqres.2005.08.002.

Arz, H.W., Pätzold, J., and Wefer, G., 1998, Correlated Millennial-Scale Changes in Surface Hydrography and Terrigenous Sediment Yield Inferred from Last-Glacial Marine Deposits off Northeastern Brazil: Quaternary Research, v. 50, p. 157-166, doi:10.1006/qres.1998.1992.

Auler, A.S., 1999, Karst evolution and palaeoclimate of eastern Brazil: University of Bristol, $268 \mathrm{p}$.

Auler, A.S., Wang, X., Edwards, R.L., Cheng, H., Cristalli, P.S., Smart, P.L., and Richards, D.A., 2004, Quaternary ecological and geomorphic changes associated with rainfall events in presently semi-arid northeastern Brazil: Journal of Quaternary Science, v. 19, p. 693-701.

Balbinot, R., 2009, Carbono, nitrogênio e razões isotópicas d13C e d15N no solo e vegetação de estágios sucessionais de floresta ombrófila densa submontana: Universidade Federal do Paraná, 103 p., doi:10.1021/om300982q.

Balée, W., 2013, Cultural forests of the Amazon: A historical ecology of people and their landscapes. (U. of A. Press, Ed.): Tuscaloosa, Alabama, University of Alabama Press, $288 \mathrm{p}$.

Barberi, M., Salgado-Labouriau, M.L., and Suguio, K., 2000, Paleovegetation and paleoclimate of "Vereda de Aguas Emendadas", central Brazil: Journal of South American Earth Sciences, v. 13, p. 241-254, doi:10.1016/S0895-9811(00)000225.

Barboni, D., and Bremond, L., 2009, Phytoliths of East African grasses: An assessment of their environmental and taxonomic significance based on floristic data: Review 
of Palaeobotany and Palynology, v. 158, p. 29-41, doi:10.1016/j.revpalbo.2009.07.002.

Barnosky, A.D., Koch, P.L., Feranec, R.S., Wing, S.L., and Shabel, A.B., 2004, Assessing the causes of late pleistocene extinctions on the continents: Science, v. 306, p. 70-75, doi:10.1126/science.1101476.

Barnosky, A.D., Lindsey, E.L., Villavicencio, N.A., Bostelmann, E., Hadly, E.A., Wanket, J., and Marshall, C.R., 2016, Variable impact of late-Quaternary megafaunal extinction in causing ecological state shifts in North and South America: Proceedings of the National Academy of Sciences, v. 113, p. 856-861, doi:10.1073/pnas.1505295112.

Barreto, E.A.S., 2010, Reconstituição da pluviosidade da Chapada Diamantina (BA) durante o Quaternário Tardio através de registros isotópicos ( $\mathrm{O}$ e $\mathrm{C}$ ) em estalagmites.: Universidade de São Paulo, 110 p.

Barreto, E.A.S., 2016, Reconstrução da paleoprecipitação no sul do Nordeste Brasileiro durante os dois últimos ciclos glaciais a partir da aplicação de registros isotópicos de oxigênio de estalagmites da Chapada Diamantina, Bahia: Universidade de São Paulo, 127 p.

Barth-Schatzmayr, O.M., and Barros, M.A., 2011, Palinologia, in Carvalho, I.D. ed., Paleontologia: Microfósseis - Paleoinvertebrados, Rio de Janeiro, Ed. Interciência.

Battarbee, R.W., 1986, Diatom analysis, in Berglund, B.E. ed., Handbook of Holocene Palaeocology and Palaeohydrology, New York, John Wiley and Sons Ltd., p. 529_ 570 .

Battarbee, R., Jones, V., Flower, R., Cameron, N., Bennion, H., Carvalho, L., and Juggins, S., 2001, Diatoms, in Smol, J., Birks, H., and Last, W. eds., Tracking environmental change using lake sediments, Dordrecht, Kluwer Academic Publishers, p. 155-201.

Behling, H., Arz, H.W., Pätzold, J., and Wefer, G., 2000, Late Quaternary vegetational and climate dynamics in northeastern Brazil, inferences from marine core GeoB 3104-1: Quaternary Science Reviews, v. 19, p. 981-994.

Behling, H., and Lichte, M., 1997, Evidence of Dry and Cold Climatic Conditions at Glacial Times in Tropical Southeastern Brazil: Quaternary Research, v. 48, p. 348-358, doi:10.1006/qres.1997.1932.

Beltrão, N., and Oliveira, M., 2007, Oleaginosas Potenciais do Nordeste para a 
Produção de Biodiesel: Documentos 177.

Bergqvist, L.P., and Almeida, E.B., 2004, Biodiversidade de mamíferos fósseis brasileiros: Rev. UnG - Geociências, v. IX, p. 54-68.

Bergqvist, L.P., Gomide, M., Cartelle, C., and Capilla, R., 1997, Faunas-locais de mamíferos pleistocênicos de Itapipoca/Ceará, Taperoá/Paraíba e Campina Granda/Paraíba. Estudo comparativo, bioestratinômico e paleoambiental: Geociências, v. 2, p. 23-32.

Bergqvist, L.P., Mansur, K., Rodrigues, M., Rodrigues-Francisco, B., Perez, R., and Beltrão, M., 2008, Bacia São José de Itaboraí, RJ - Berço dos mamíferos no Brasil, in Winge, M., Schobbenhaus, C., Souza, C., Fernandes, A., Berbert-Born, M., and Queiroz, E. eds., Sítios geológicos e paleontológicos do Brasil, p. 413432.

Bicudo, C.E.M., and Bicudo, R.M., 1970, Algas de águas continentais brasileiras: São Paulo, Fundação Brasileira para o Desenvolvimento do Ensino de Ciências FUNBEC, $228 \mathrm{p}$.

Blaauw, M., and Christen, J.A., 2011, Flexible paleoclimate age-depth models using an autoregressive gamma process: Bayesian Analysis, v. 6, p. 457-474, doi:10.1214/11-BA618.

Bond, G., Showers, W., Cheseby, M., Lotti, R., Almasi, P., deMenocal, P., Priore, P., Cullen, H., Hajdas, I., and Bonani, G., 1997, A pervasive Millennial-scale cycle in the North Atlantic Holocene Climate: Science, v. 278, p. 1257-1266.

Borrero, L.A., 2008, Extinction of Pleistocene megamammals in South America: The lost evidence: Quaternary International, v. 185, p. 69-74, doi:10.1016/j.quaint.2007.10.021.

Boutton, T.W., 1991, Stabel carbon isotope ratios of natural materials. II. Atmospheric, terrestrial, marine and freshwater environments, in Coleman, D.. and Fry, B. eds., Carbon isotope techniques, New York, Academic Press, p. 155-171.

Boutton, T.W., 1996, Stable carbon isotope ratios of soils organic matter and their use as indicators of vegetation and climate change, in Boutton, T.W. and Yamasaki, S.I. eds., Mass spectrometry of soils, New York, Marcel Dekker, p. 47-82.

Bozarth, S., 1992, Classification of opal phytoliths formed in selected dicotyledons native to the Great Plains, in Rapp, G. and Mulholland, S. eds., Phytolith Systematics. Advances in archaeological and museum science, Boston, MA, Springer, p. 193-214. 
Brand, M.A., Oliveira, L. da C., Lacerda, S.R., Toniolo, E.R., Júnior, G.L., and Campello, R.B., 2015, Caracterização da vegetação da caatinga do sul do piauí para geração de energia: Floresta, v. 45, p. 477-486, doi:10.5380/rf.v45i3.27753.

Bush, M., Miller, M.C., De Oliveira, P.E., and Colinvaux, P.A., 2002, Orbital forcing signal in sediments of two Amazonian lakes: Paleolimno, v. 27, p. 341-352.

Bush, M.B., and Silman, M.R., 2004, Observations on Late Pleistocene cooling and precipitation in the lowland Neotropics: Journal of Quaternary Science, v. 19, p. 677-684, doi:10.1002/jqs.883.

Buso Jr, A. et al., 2013, Late pleistocene and holocene vegetation, climate dynamics, and amazonian taxa in the atlantic forest, Linhares, SE, Brazil, in Jull, A. and Hatté, C. eds., Proceedings of the 21st International Radiocarbon Conference, v. 55, p. 1747-1762.

Cabral, A., Romão, G.O., Salimena, F.R.G., and Neto, L.M., 2013, Ericaceae no Parque Estadual da Serra do Papagaio, Minas Gerais, Brasil - Dados preliminares, in $64^{\circ}$ Congresso Nacional de Botânica, Belo Horizonte, Minas Gerais.

Campbell, I.D., 1991, Experimental mechanical destruction of pollen grains: Palynology, v. 15, p. 29-33, doi:10.1080/01916122.1991.9989387.

Carson, J.F., Mayle, F.E., Whitney, B.S., Iriarte, J., and Soto, J.D., 2016, PreColumbian ring ditch construction and land use on a 'chocolate forest island' in the Bolivian Amazon: Journal of Quaternary Science, v. 31, p. 337-347, doi:10.1002/jqs.2835.

Cartelle, C., 1999, Pleistocene mammals of the Cerrado and Caatinga of Brazil, in Eisenberg, J. and Redford, K. eds., Mammals of the Neotropics, Chicago, The University of Chicago Press, p. 27-46.

Cartelle, C., 2000, Preguiças terrícolas, essas desconhecidas: Ciência Hoje, v. 27, p. $18-25$.

Cartelle, C., 1994, Tempo passado - Mamíferos do Pleistoceno em Minas Gerais: Belo Horizonte, Minas Gerais, Palco, 131 p.

Cartelle, C., and Hartwig, C., 1996, A new extinct primate among the Pleistocene megafauna of Bahia, Brazil: Proc Natl Acad Sci U S A, v. 93, p. 6405-6409, doi:10.3406/bspf.1992.9504.

Cavalcanti, D., and Tabarelli, M., 2004, Distribuição das Plantas AmazônicoNordestinas no Centro de Endemismo Pernambuco: Brejos de Altitude vs. 


\section{Florestas de Terras Baixas.:}

Cerling, T.E., and Harris, J.M., 1999, Carbon isotope fractionation between diet and bioapatite in ungulate mammals and implications for ecological and paleoecological studies: Oecologia, v. 120, p. 347-363.

Cerling, T.E., Harris, J.M., and Leakey, M.G., 1999, Browsing and grazing in elephants : the isotope record of modern and fossil proboscideans: Oecologia, v. 120, p. 364-374.

Cerling, T.E., Wang, Y., and Quade, J., 1993, Expansion of C4 ecosystems as an indicator of global ecological change in the late Miocene: Nature, v. 361, p. 344345, doi:10.1038/361344a0.

Cheng, H. et al., 2013, Climate change patterns in Amazonia and biodiversity.: Nature communications, v. 4, p. 1411, doi:10.1038/ncomms2415.

Cheng, H. et al., 2009, Timing and structure of the 8.2. kyr B.P. event inferred from $\delta 180$ records of stalagmites from China, Oman, and Brazil: Geology, v. 37, p. 1007-1010, doi:10.1130/G30126A.1.

Cheng, H., Sinha, A., Wang, X., Cruz, F.W., and Edwards, R.L., 2012, The Global Paleomonsoon as seen through speleothem records from Asia and the Americas: Climate Dynamics, v. 39, p. 1045-1062, doi:10.1007/s00382-012-1363-7.

Christiansen, P., 2004, Body size in proboscideans, with notes on elephant metabolism: Zoological Journal of the Linnean Society, v. 140, p. 523-549, doi:10.1111/j.1096-3642.2004.00113.x.

Clement, C.R., Lleras, E., and van Leeuwen, J., 2005, O potencial das palmeiras tropicais no Brasil: acertos e fracassos das última décadas: Agrociência, v. IX, p. 67-71.

Climate-Data, 2018, No Title:, https://pt.climate-data.org/america-dosul/brasil/paraiba/sao-joao-do-cariri-312301/.

Colinvaux, P.A., and De Oliveira, P.E., 2001, Amazon plant diversity and climate through the Cenozoic: Palaeogeography, Palaeoclimatology, Palaeoecology, v. 166, p. 51-63, doi:10.1016/S0031-0182(00)00201-7.

Colinvaux, P.A., De Oliveira, P.E., Moreno, J.E., Miller, M.C., and Bush, M.B., 1996, A Long Pollen Record from Lowland Amazonia: Forest and Cooling in Glacial Times: Science, v. 274, p. 85-88, doi:10.1126/science.274.5284.85.

Colinvaux, P.A., De Oliveira, P.E., and Moreno Patiño, J., 1999, Amazon Pollen manual and atlas: Amsterdam, Harwood Academic Publishers, $332 \mathrm{p}$. 
Cook, K.H., 2005, Hadley circulation dynamics: Seasonality and the Role of Continents, in Diaz, H.F. and Bradley, R.S. eds., The Hadley Circulation: Present, Past and Future. Advances in global change research, Dordrecht/Boston/London, Kluwer Academic Publishers, p. 61-83.

CPRM.BRASIL, 1964, Estudo hidrogeológico do Brejo de São José - Arcoverde: 2. CPRM, 2005, Serviço Geológico do Brasil. Projeto cadastro de fontes de abastecimento por água subterrânea - Diagnóstico do município de Buíque, estado de Pernambuco:

Cristalli, P.S., 2006, Macrofitofósseis em tufos calcários quaternários do norte da Bahia como indicadores paleoclimáticos: Universidade de São Paulo, 195 p.

Croat, T.B., 1988, Ecology and life forms of Araceae: Aroideana, v. 11, p. 4-52.

Cruz, F.W., Vuille, M., Burns, S.J., Wang, X., Cheng, H., Werner, M., Lawrence Edwards, R., Karmann, I., Auler, A.S., and Nguyen, H., 2009, Orbitally driven east-west antiphasing of South American precipitation: Nature Geoscience, v. 2, p. 210-214, doi:10.1038/ngeo444.

Dantas, M.A.T., Dutra, R.P., Cherkinsky, A., Fortier, D.C., Kamino, L.H.Y., Cozzuol, M.A., Ribeiro, A. de S., and Vieira, F.S., 2013, Paleoecology and radiocarbon dating of the Pleistocene megafauna of the Brazilian Intertropical Region: Quaternary Research, v. 79, p. 61-65, doi:10.1016/j.yqres.2012.09.006.

Dantas, M.A.T., Santos, D.B., Liparini, A., Queiroz, A.N. De, Carvalho, O.A. De, Castro, É.S.V. De, and Cherkinsky, A., 2014, Dated evidence of the interaction between humans and megafauna in the late Pleistocene of Sergipe state, northeastern Brazil: Quaternary International, v. 352, p. 197-199, doi:10.1016/j.quaint.2014.09.040.

Davis, O.K., 1987, Spores of the dung fungus Sporormiella: Increased abundance in historic sediments and before Pleistocene megafaunal extinction: Quaternary Research, v. 28, p. 290-294, doi:10.1016/0033-5894(87)90067-6.

Davis, O.K., and Shafer, D.S., 2006, Sporormiella fungal spores, a palynological means of detecting herbivore density: Palaeogeography, Palaeoclimatology, Palaeoecology, v. 237, p. 40-50, doi:10.1016/j.palaeo.2005.11.028.

DeNiro, M.J., and Epstein, S., 1978, Influence of diet on the distribution of carbon isotopes in animals: Geochimica et Cosmochimica Acta, v. 42, p. 495-506, doi:10.1016/0016-7037(78)90199-0.

Dickau, R., Whitney, B.S., Iriarte, J., Mayle, F.E., Soto, J.D., Metcalfe, P., Street- 
Perrott, F.A., Loader, N.J., Ficken, K.J., and Killeen, T.J., 2013, Differentiation of neotropical ecosystems by modern soil phytolith assemblages and its implications for palaeoenvironmental and archaeological reconstructions: Review of Palaeobotany and Palynology, v. 193, p. 15-37, doi:10.1016/j.revpalbo.2013.01.004.

Diniz-Filho, J.A.F., 2004, Macroecological analyses support an overkill scenario for Late Pleistocene extinctions: Braz. J. Biol., v. 64, p. 407-414.

Duffin, K.I., Gillson, L., and Willis, K.J., 2008, Testing the sensitivity of charcoal as an indicator of fire events in savanna environments: Quantitative predictions of fire proximity, area and intensity: Holocene, v. 18, p. 279-291, doi:10.1177/0959683607086766.

Dupont, L.M., Schlütz, F., Ewah, C.T., Jennerjahn, T.C., Paul, A., and Behling, H., 2009, Two-step vegetation response to enhanced precipitation in Northeast Brazil during Heinrich event 1: Global Change Biology, v. 16, p. 1647-1660, doi:10.1111/j.1365-2486.2009.02023.x.

Erdtman, G., 1986, Pollen morphology and plant taxonomy: angiosperms: Brill Archive.

Etchevarne, C., 2000, A ocupação humana do Nordeste Brasileiro antes da colonização portuguesa: Revista USP, v. 44, p. 112-141.

Farquhar, G.D., Ehleringer, J.R., and Hubik, K.T., 1989, Carbon isotope discrimination and photosyntesis: Annual Review of Plant Physiology and Plant Molecular Biology, v. 40, p. 503-537.

Ferigolo, J., 1993, Extinções de pleistocênicos Sul-Americanos - A hipótese das infecções: uma solução pela imunologia, in $13^{\circ}$ Congresso Brasileiro de Paleontologia - $1^{\circ}$ Simpósio Paleontológico do Cone Sul, São Leopoldo, Boletim de resumos, p. 192.

França, L. de M., Asevedo, L. de, Dantas, M.A.T., Bocchiglieri, A., Avilla, L.S., Lopes, R.P., and Silva, J.L.L., 2015, Review of feeding ecology data of Late Pleistocene mammalian herbivores from South America and discussions on niche differentiation: Earth Science Reviews, v. 140, p. 158-165, doi:10.1016/j.earscirev.2014.10.006.

França, L.D.M., Dantas, M.A.T., Bocchiglieri, A., Cherckinsky, A., de Souza Ribeiro, A., and Bocherens, H., 2014, Chronology and ancient feeding ecology of two upper Pleistocene megamammals from the Brazilian Intertropical Region: Quaternary Science Reviews, v. 99, p. 78-83, 
doi:10.1016/j.quascirev.2014.04.028.

Fürstenberger, C.B., 2001, Interpretações paleolimnológicas do Quaternário recente a partir da análise da comunidade de diatomáceas (Bacillariophyceae) no sedimento do Rio Icatu, município de Xique-Xique, Estado da Bahia, Brasil: Universidade Estadual Paulista, Rio Claro, $128 \mathrm{p}$.

Garcia, R.J.F., 2003, Estudo florístico dos campos alto-montanos e matas nebulares do Parque Estadual da Serra do Mar - Núcleo Curucutu, São Paulo, SP, Brasil: Universidade de São Paulo, 356 p.

Garcia, C., 1984, O que é o nordeste brasileiro? São Paulo, Ed. Brasiliense.

van Geel, B., Guthrie, R.D., Altmann, J.G., Broekens, P., Bull, I.D., Gill, F.L., Jansen, B., Nieman, A.M., and Gravendeel, B., 2011, Mycological evidence of coprophagy from the feces of an Alaskan Late Glacial mammoth: Quaternary Science Reviews, v. 30, p. 2289-2303, doi:10.1016/j.quascirev.2010.03.008.

Germain, H., 1981, Flore de diatomêes: eaux douce et saumâtres: Paris, Ed. Boubée, $444 \mathrm{p}$.

Gill, J.L., 2014, Ecological impacts of the late Quaternary megaherbivore extinctions: New Phytologist, v. 201, p. 1163-1169, doi:10.1111/nph.12576.

Gill, J.L., Williams, J.W., Jackson, S.T., Lininger, K.B., and Robinson, G.S., 2009, Pleistocene Megafaunal Collapse, Novel Plant Communities, and Enhanced Fire Regimes in North America: Science, v. 326, p. 1100-1103, doi:10.1126/science.1179504.

Giulietti, A.M., Virgínio, J.F., and Harley, R.M., 2004, Diagnóstico da vegetação nativa do bioma Caatinga, in Biodiversidade da Caatinga: áreas e ações prioritárias para a conservação, p. 48-90, doi:10.1007/BF02055145.

Gomes, H.. (org. ., 1995, Geologia e recuros minerais do Estado de Pernambuco.:

Grayson, D.K., 1984, Quantitative zooarchaeology: New York, Academic Press, 202 p.

Grimm, E.C., 1987a, CONISS: A fortran 77 program for stratigraphically constrained cluster analysis by the method of incremental sum of squares: Computers \& Geosciences, v. 13, p. 13-35.

Grimm, E.C., 1987b, CONISS: Textbook of Polen Analyses: New York, Ed. Wiley.

Grimm, E.C., and Troostheide, C.D., 1994, Tilia 2.00, program for plotting palynological diagrams: Springfield, Illinois State Museum.

Haberle, S.G., 1997, Upper Quaternary vegetation and climate history of the Amazon 
Basin: correlating marine and terrestrial pollen records, in Flood, R.D., Piper, D.J.W., Klaus, A., and Peterson eds., Proceedings of the Ocean Drilling Program, Scientific Results, n. 155, p. 381-396.

Harley, R.M., 1995, Introduction, in Stannard, B.L. ed., Flora of Pico das Almas, Chapada Diamantina, Bahia, Brazil, Kew, Royal Botanic Gardens, p. 1-42.

Hasui, Y., 2012, Sistema Orogênico Borborema, in Hasui, Y., Carneiro, C.D.R., Almeida, F.F.M., and Bartorelli, A. eds., Geologia do Brasil, São Paulo, Beca, p. 254-288.

Heinrich, H., 1988, Origin and Consequences of Cyclic Ice Rafting in the Northeast Atlantic Ocean During the Past 130,000 Years: Quaternary Research, v. 29, p. 142-152, doi:10.1016/0033-5894(88)90057-9.

Hilder, F., 2007, Contribuição à Palinologia das Caatingas Contribuição à Palinologia das Caatingas Francisco Hilder Magalhães e Silva:

Hogg, A.G. et al., 2013, SHCal13 Southern Hemisphere Calibration, 0-50,000 Years cal BP: Radiocarbon, v. 55, p. 1889-1903, doi:10.2458/azu_js_rc.55.16783.

INMET, 2014, INMET: Instituto Nacional de Meteorologia, www.inmet.gov.br/portal/index.php?r=estacoes/estacoesautomaticas (accessed November 2014).

Iriarte, J., and Paz, E.A., 2009, Phytolith analysis of selected native plants and modern soils from southeastern Uruguay and its implications for paleoenvironmental and archeological reconstruction: Quaternary International, v. 193, p. 99-123, doi:10.1016/j.quaint.2007.10.008.

ITP, I. de T. de P., 2014, Relatório de impacto ambiental - rima: Barragem São Bento do Una.:

Jaeschke, A., Rühlemann, C., Arz, H., Heil, G., and Lohmann, G., 2007, Coupling of millennial-scale changes in sea surface temperature and precipitation off northeastern Brazil with high-latitude climate shifts during the last glacial period: Paleoceanography, v. 22, p. n/a-n/a, doi:10.1029/2006PA001391.

Jesus, M., Rodal, N., Sales, M.F., José, M., and Gomes, A., 2005, Flora de um Brejo de Altitude na escarpa oriental do planalto da: v. 19, p. 843-858.

Jolly, A.B., 1993, Botânica: introdução à taxonomia vegetal: São Paulo, Companhia Editora Nacional, 777 p.

Jorgensen, E.G., 1955, Solubility of the Silica in Diatoms: Physiologia Plantarum, v. 8, p. 846-851. 
Jung-Mendaçolli, S.L., Bernacci, L.C., and Freitas, M. de F., 2010, Nova espécie de Cybianthus Mart. ( Myrsinaceae ) do sudeste do Brasil: Acta bot. bras., v. 24, p. 671-673.

Kinoshita, A., Barreto, A., Alves, R., Maria Figueiredo, A., Eduardo de Souza Sarkis, J., Dias, M.L., and Baffa, O., 2008, ESR dating of teeth from northeastern Brazilian megafauna: Radiation Measurements, v. 43, p. 809-812, doi:10.1016/j.radmeas.2007.11.075.

Kipnis, R., 1998, Early hunter-gatherers in the Americans: perspectives from central Brazil: Antiquity, v. 72, p. 581.

Koch, P.L., and Barnosky, A.D., 2006, Late Quaternary Extinctions: State of the Debate: Annual Review of Ecology, Evolution, and Systematics, v. 37, p. 215250, doi:10.1146/annurev.ecolsys.34.011802.132415.

Kumari, I., and Kumarasamy, D., 2014, Studies on phytoliths in some marine plants: International Journal of Plant, Animal and Environmental Sciences, p. 1-5.

Ledru, M.-P., 1993, Late Quaternary environmental and climatic changes in Central Brazil: Quaternary Research, v. 39, p. 90-98.

Ledru, M., 1992, Late Quaternary environmental changes in Central Brazil: Quaternary Research, v. 39, p. 90-98.

Ledru, M.-P., Braga, P.I.S., Soubiès, F., Fournier, M., Martin, L., Suguio, K., and Turcq, B., 1996, The last 50,000 years in the Neotropics (Southern Brazil): evolution of vegetation and climate: Palaeogeography, Palaeoclimatology, Palaeoecology, v. 123, p. 239-257.

Ledru, M.-P., Cordeiro, R.C., Dominguez, J.M.L., Martin, L., Mourguiart, P., and Sifeddine, A., 2001, Late-Glacial Cooling in Amazonia Inferred from Pollen at Lagoa do Caçó, Northern Brazil: Quaternary Research, v. 55, p. 47-56, doi:10.1006/qres.2000.2187.

Ledru, M.P., Montade, V., Blanchard, G., and Hély, C., 2016, Long-term Spatial Changes in the Distribution of the Brazilian Atlantic Forest: Biotropica, v. 48, p. 159-169, doi:10.1111/btp.12266.

Ledru, M.P., Mourguiart, P., Ceccantini, G., Turcq, B., and Sifeddine, A., 2002, Tropical climates in the game of two hemispheres revealed by abrupt climatic change: Geology, v. $30, \quad$ p. 275-278, doi:10.1130/00917613(2002)030<0275:TCITGO>2.0.CO;2.

Ledru, M.-P., Salatino, M.L.F., Ceccantini, G., Salatino, A., Pinheiro, F., and Pintaud, 
J.-C., 2007, Regional assessment of the impact of climatic change on the distribution of a tropical conifer in the lowlands of South America: Diversity and Distributions, v. 13, p. 761-771, doi:10.1111/j.1472-4642.2007.00389.x.

Ledru, M., Salgado-Labouriau, M.L., and Lorscheitter, M.L., 1998, Vegetation dynamics in southern and central Brazil during the last 10,000 yr B.P.: Review of Palaeobotany and Palynology, v. 99, p. 131-142, doi:10.1016/S00346667(97)00049-3.

Lemos, J.R., and Rodal, M.J.N., 2002, Fitossociologia do componente lenhoso de um trecho da vegetação de caatinga no Parque Nacional Serra da Capivara, Piauí, Brasil: Acta bot. bras., v. 16, p. 23-42, doi:10.1590/S0102-33062002000100005. Levin, J., and Costa, S.F., 1987, Estatística aplicada a ciências humanas (Harbra, Ed.): São Paulo.

Lima, B.G. de, and Coelho, M.D.F.B., 2018, FITOSSOCIOLOGIA E ESTRUTURA DE UM FRAGMENTO FLORESTAL DA CAATINGA, CEARÁ, BRASIL: Ciência Florestal, v. 28, p. 809-819, doi:10.5902/1980509832095.

Locatelli, E., and Machado, I.C., 2004, Fenologia das Espécies Arbóreas de uma Mata Serrana (Brejo de Altitude) em Pernambuco, Nordeste do Brasil.:

Locosselli, G.M., Cardim, R.H., and Ceccantini, G., 2016, Rock outcrops reduce temperature-induced stress for tropical conifer by decoupling regional climate in the semiarid environment: Int $\mathrm{J}$ Biometeorol, v. 60, p. 639-649, doi:10.1007/s00484-015-1058-y.

Locosselli, G.M., and Ceccantini, G., 2012, Plasticity of stomatal distribution pattern and stem tracheid dimensions in Podocarpus lambertii : an ecological study: Annals of Botany, v. 110, p. 1057-1066, doi:10.1093/aob/mcs179.

Lombardo, U., Ruiz-Pérez, J., and Madella, M., 2016, Sonication improves the efficiency, efficacy and safety of phytolith extraction: Review of Palaeobotany and Palynology, v. 235, p. 1-5, doi:10.1016/j.revpalbo.2016.09.008.

Longhi-Wagner, H.M., 2012, Poaceae: an overview with reference to Brazil: Rodriguésia, v. 63, p. 089-100.

Lorente, F.L. et al., 2015, Fitólitos como indicadores de mudanças ambientais durante o Holoceno na costa norte do Estado do Espírito Santo: Quaternary and Environmental Geosciences, v. 6, p. 26-40, doi:10.5380/abequa.v6i1.36239.

Lorente, F.L., Buso Jr, A., de Oliveira, P.E., and Pessenda, L.C.R., 2017, Atlas palinológico: Laboratório 14C (FEALQ, Ed.): Piracicaba, 333 p. 
Lorenzi, H., 1998, Árvores brasileiras: Manual de identificação e cultivo de plantas arbóreas nativas do Brasil: $352 \mathrm{p}$.

Lorenzi, H., 1992, Árvores Brasileiras. Manual de identificação e cultivo de plantas arbóreas nativas do Brasil: Nova Odessa, SP, Instituto Plantarum, $384 \mathrm{p}$.

Lorenzi, H., 2009, Árvores brasileiras: Nova Odessa, SP, Instituto Plantarum, 384 p.

Lorenzi, H., 2008, Plantas daninhas do Brasil: Nova Odessa, SP, Instituto Plantarum, $640 \mathrm{p}$.

Mabesoone, J., Oliveira, L., and Damasceno, J., 1990, Desenvolvimento dos tanques fossilíferos no semi-árido norteriograndense, in Congresso Brasileiro de Geologia, Natal - RN, Anais, 36, p. 733-741.

Macfadden, B.J., 2000, Cenozoic Mammalian herbivores from the Americas: Reconstructing ancient diets an terrestrial communities: Annu. Rev. Ecol. Syst., v. 31, p. 33-59.

MacFadden, B.J., 2006, Extinct mammalian biodiversity of the ancient New World tropics: Trends in Ecology and Evolution, v. 21, p. 157-165, doi:10.1016/j.tree.2005.12.003.

Maezumi, S.Y., Power, M.J., Mayle, F.E., McLauchlan, K.K., and Iriarte, J., 2015, Effects of past climate variability on fire and vegetation in the cerrãdo savanna of the Huanchaca Mesetta, NE Bolivia: Climate of the Past, v. 11, p. 835-853, doi:10.5194/cp-11-835-2015.

Marchant, R., and Hooghiemstra, H., 2004, Rapid environmental change in African and South American tropics around 4000 years before present: A review: EarthScience Reviews, v. 66, p. 217-260, doi:10.1016/j.earscirev.2004.01.003.

Marengo, J.A., Torres, R.R., and Alves, L.M., 2017, Drought in Northeast Brazil-past, present, and future: Theoretical and Applied Climatology, v. 129, p. 1189-1200, doi:10.1007/s00704-016-1840-8.

Martin, G., 2005, As pinturas rupestres do sítio Alcobaça, Buíque - PE, no contexto da tradição agreste: Clio Série Arqueológica,.

Martinelli, L.A., Almeida, S., Brown, I.F., Moreira, M.Z., Victoria, R.L., Sternberg, L.S.L., Ferreira, C.A.C., and Thomas, W.W., 1998, Stable carbon isotope ratio of tree leaves, boles and fine litter in a tropical forest in Rondônia, Brazil: Oecologia, v. 114, p. $170-179$.

Mascarenhas, J.C., Beltrão, B.A., Souza Jr., L.C., Galvão, M.J.T., Pereira, S.N., Miranda, L.F., and Miranda, J.L.F., 2005a, Projeto cadastro de fontes de 
abastecimento por água subterrânea. Diagnóstico do município de Afrânio, estado de Pernambuco:

Mascarenhas, J.C., Beltrão, B.A., Souza Jr., L.C., Morais, F., Mendes, V.A., and Miranda, L.F., 2005b, Projeto cadastro de fontes de abastecimento por águas subterrânes. Diagnóstico do município de São João do Cariri, estado da Paraíba.: Mazumdar, J., 2011, Phytoliths of pteridophytes: South African Journal of Botany, v. 77, p. 10-19, doi:10.1016/j.sajb.2010.07.020.

Medeiros, V.B., De Oliveira, P.E., Santos, R.A., Barreto, A.M.F., Oliveira, M.A.T., And Pinaya, J.L.D., 2018, New Holocene pollen records from the Brazilian Caatinga: Anais da Academia Brasileira de Ciências, v. 90, p. 2011-2023, doi:10.1590/0001-3765201820170161.

Mendes, V.R., 2016, Registro sedimentar quaternário na Bacia do Rio Parnaíba, Piauí: um estudo multi-indicadores voltado à investigação de mudanças climáticas: Universidade de São Paulo, 100 p.

Mendonça, R., 2012, Diversidade de toxodontes pleistocênicos (Notoungulata, Toxodontidae): uma nova visão: Universidade de São Paulo, 151 p.

Mercader, J., Bennett, T., Esselmont, C., Simpson, S., and Walde, D., 2011, Soil phytoliths from miombo woodlands in Mozambique: Quaternary Research, v. 75, p. 138-150, doi:10.1016/j.yqres.2010.09.008.

Misumi, S.Y., Asevedo, L., Avilla, L. dos S., Barth, O.M., and de Barros, M.A., 2016, Técnica de extração de palinomorfos em cálculos déntarios de gonfotérios sulAmericanos: Anuario do Instituto de Geociencias, v. 39, p. 127-132, doi:10.11137/2016_1_127_132.

Mofatto, M., 2005, Estudo multi/interdisciplinar de reconstrução da vegetação e clima do Parque Estadual da Serra do Mar - Núcleo Curucutu, São Paulo, SP no Quaternário tardio: Universidade de São Paulo, 158 p.

Montade, V., Ledru, M.-P., Burte, J., Martins, E.S.R.P.R., Verola, C.F., Costa, I.R. da, Magalhães e Silva, F.H., and Silva, F.H.M., 2014, Stability of a Neotropical microrefugium during climatic instability (J. Williams, Ed.): Journal of Biogeography, v. 41, p. 1-12, doi:10.1111/jbi.12283.

Moreira, J.N., Lira, M.A., Santos, M.V.F., Ferreira, M.A., Araújo, G.G.L., Ferreira, R.L.C., and Silva, G.., 2006, Caracterização da vegetação de caatinga e da dieta de novilhos no Sertão de Pernambuco: Pesq.agropec.bras., v. 41, p. 1643-1651, doi:10.1590/S1516-35982011000100010. 
Moro, R.S., and Fürstenberger, C.B., 1997, Catálogo dos principais parâmetros ecológicos de diatomáceas não-marinhas: Ponta Grossa, Editora UEPG, 282 p.

Mothé, D., Avilla, L.S., and Winck, G.R., 2010, Population structure of the gomphothere Stegomastodon waringi (Mammalia: Proboscidea: Gomphotheriidae) from the Pleistocene of Brazil: Anais da Academia Brasileira de Ciencias, v. 82, p. 983-996, doi:10.1590/S0001-37652010000400020.

Mulholland, S.C., 1989, Phytolith shape frequencies in North Dakota grasses: a comparison to general patterns: Journal of Archaeological Science, v. 16, p. 489511, doi:10.1016/0305-4403(89)90070-8.

Nace, T.E., Baker, P.A., Dwyer, G.S., Silva, C.G., Rigsby, C.A., Burns, S.J., Giosan, L., Otto-Bliesner, B., Liu, Z., and Zhu, J., 2014, The role of North Brazil Current transport in the paleoclimate of the Brazilian Nordeste margin and paleoceanography of the western tropical Atlantic during the late Quaternary: Palaeogeography, Palaeoclimatology, Palaeoecology, v. 415, p. 3-13, doi:10.1016/j.palaeo.2014.05.030.

Nascimento, L., 2008, Dinâmica vegetacional e climática holcênica da Caatinga, na região do Parque Nacional do Catimbau, Buíque - PE: Universidade Federal de Pernambuco, $113 \mathrm{p}$.

Nascimento, T.C., 2012, Reconstituição da história quaternária da Mata Atlântica na região centro-norte do estado do Espírito Santo: Universidade de Guarulhos, 229 p.

Novello, V.F. et al., 2012, Multidecadal climate variability in Brazil's Nordeste during the last 3000 years based on speleothem isotope records: Geophysical Research Letters, v. 39, p. n/a-n/a, doi:10.1029/2012GL053936.

O'Leary, M.H., 1988, Carbon isotopes in photosyntesis: Bioscience, v. 38, p. 328-336. Oliveira, É. V., Barreto, A.M.F., and Alves, R.S., 2009, Aspectos sistemáticos, paleobiogeográficos e paleoclimáticos dos mamíferos fósseis do Quaternário de Fazenda Nova, PE, nordeste do Brasil: Gaea - Journal of Geoscience, v. 5, p. 7585, doi:10.4013/gaea.2009.52.04.

Oliveira, É. V., Porpino, K.O., and Barreto, A.F., 2010, On the presence of Glyptotherium in the Late Pleistocene of Northeastern Brazil, and the status of "Glyptodon" and "Chlamydotherium". Paleobiogeographic implications: N. Jb. Geol. Paläont. Abh., v. 258, p. 353-363, doi:10.1127/0077-7749/2010/0116.

Oliveira, É.V., Porpino, K.D.O., and Silva, F.M., 2013, New material of 
Pachyarmatherium from the late Pleistocene of northeastern Brazil: insights into its morphology and systematics: Paläontologische Zeitschrift, v. 87, p. 505-513, doi:10.1007/s12542-013-0166-4.

De Oliveira, P.E., 1992, A palynological record of late Quaternary vegetational and climatic change in Southeastern Brazil: The Ohio State University, $134 \mathrm{p}$.

De Oliveira, P.E., Barreto, A.M.F., and Suguio, K., 1999, Late Pleistocene/Holocene climatic and vegetational history of the Brazilian caatinga: the fossil dunes of the middle São Francisco River: Palaeogeography, Palaeoclimatology, Palaeoecology, v. 152, p. 319-337.

De Oliveira, P.E., Behling, H., Ledru, M.-P., Barberi, M., Bush, M.B., SalgadoLabouriau, M.L., Medeanic, S., Barth, O.M., Barros, M.A., and Scheel-Ybert, R., 2005, Paleovegetação e paleoclimas do Quaternário do Brasil, in Souza, C, R.G., Suguio, K., Oliveira, A.M.S., and De Oliveira, P.E. eds., Quaternário do Brasil, Ribeirão Preto - SP, Holos Editora, p. 52-74.

De Oliveira, P.E., Pessenda, L.C.R., Barreto, A.M.F., Oliveira, É. V., and Santos, J.C., 2014, Paleoclimas da caatinga brasileira durante o quaternário tardio, in Carvalho, I.S., Garcia, M.J., Lana, C., and Strohschoen Jr., O. eds., Paleontologia: Cenarios de Vida-Paleoclimas-Volume 5, Rio de Janeiro, Ed. Interciência, p. 501-516.

Oliveira, P.P., and Santos, F.A.., 2014, Prospecção palinológica em méis da Bahia: Feira de Santana - Bahia, Print Midia, $120 \mathrm{p}$.

Oliveira, Y.A.B., 2012, Descrição sistemática e inferências tafonômicas em jazigo fossilífero de mamíferos pleistocênicos, município Piranhas, Algoas: Universidade Federal de Alagoas, 91 p.

Patrick, R., and Reimer, C.W., 1966a, The Diatoms of the United States, in Monographs of the Academy of Natural Sciences of Philadelphia, Pennsilvania, $v$. Part I, p. 213.

Patrick, R., and Reimer, C., 1966b, The diatoms of the United States exclusive of Alaska and Hawaii: Academy of Natural Sciences of Philadelphia, 672 p.

Paula-Couto, C., 1980, Fossil pleistocene to subrecent mammals from Northeastern Brazil: Anais da Academia Brasileira de Ciências, v. 52, p. 144-151.

Paula-Couto, C., 1975, Mamíferos fósseis do Quaternário do sudeste brasileiro:

Boletim Paranaense de Geociências, v. 33, p. 89-132.

Paula-Couto, C., 1979, Tratado de Paleomastozoologia: Rio de Janeiro, Academia Brasileira de Ciências, 563 p. 
Paulo, P.O., and Bertini, R.J., 2015, Mamíferos Fósseis Do Limite Pleistoceno/Holoceno Do Estado De Goiás: Revista do Instituto Geológico, v. 36, p. 61-75, doi:10.5935/0100-929X.20150008.

Pessenda, L.C.R. et al., 2009, The evolution of a tropical rainforest/grassland mosaic in southeastern Brazil since 28,000 14C yr BP based on carbon isotopes and pollen records: Quaternary Research, v. 71, p. 437-452, doi:10.1016/j.yqres.2009.01.008.

Pessenda, L.C.R., Gouveia, S.E.M., Ribeiro, A.S., De Oliveira, P.E., and Aravena, R., 2010a, Late Pleistocene and Holocene vegetation changes in northeastern Brazil determined from carbon isotopes and charcoal records in soils: Palaeogeography, Palaeoclimatology, Palaeoecology, v. 297, p. 597-608, doi:10.1016/j.palaeo.2010.09.008.

Pessenda, L.C.R., Ledru, M.P., Gouveia, S.E.M., Aravena, R., Ribeiro, A.S., Bendashsollil, J.A., and Boulet, R., 2005, Holocene palaeoenvironmental reconstruction in norteastern Brazi inferred from polen,, charcoal and carboon isotope records: The Holocene, v. 15, p. 812-820, doi:10.1191/0959683605hl855ra.

Pessenda, L.C.R., Saia, S.E.M.G., Gouveia, S.E.M., Ledru, M.-P., Sifeddine, A., Amaral, P.G.C., and Bendassolli, J.A., 2010b, Last millennium environmental changes and climate inferences in the Southeastern Atlantic forest, Brazil: Anais da Academia Brasileira de Ciencias, v. 82, p. 717-729.

Peterson, B.J., and Howarth, R.W., 1987, Sufur, carbon and nitrogen isotopes used to trace organic matter flow in the salt marsh estuaries of Sapelo Island, Georgia: Limnology and Oceanography, v. 32, p. 1195-1213.

Piperno, D.R., 2006, Phytoliths: A compreensive guide for archaeologists and paleoecologists: Lanham, Rowman Altamira Press, 238 p.

Porpino, K.D.O., Fernicola, J.C., and Bergqvist, L.P., 2009, A new cingulate (Mammalia: Xenarthra), Pachyarmatherium brasiliense sp. nov., from the Late Pleistocene of Northeastern Brazil: Journal of Vertebrate Paleontology, v. 29, p. 881-893, doi:10.1671/039.029.0305.

Prous, A., and Fogaça, E., 1999, Archaeology of the Pleistocene-Holocene boundary in Brazil: Quaternary International, v. 53-54, p. 21-41, doi:10.1016/S10406182(98)00005-6.

Raczka, M.F., Bush, M.B., Folcik, A.M., and McMichael, C.H., 2016, Sporormiella as a 
tool for detecting the presence of large herbivores in the Neotropics: Biota Neotropica, v. 16, p. 1-9, doi:10.1590/1676-0611-BN-2015-0090.

Raczka, M.F., Bush, M.B., and De Oliveira, P.E., 2018, The collapse of megafaunal populations in southeastern Brazil: Quaternary Research (United States), v. 89, p. 103-118, doi:10.1017/qua.2017.60.

Ramsey, C.B., 2008, Deposition models for chronological records: Quaternary Science Reviews, v. 27, p. 42-60, doi:10.1016/j.quascirev.2007.01.019.

Raven, P., Evert, R., and Eichhorn, S., 2001, Biologia vegetal: Rio de Janeiro, Guanabara Koogan, 728 p.

Reflora, J.B. do R. de J., 2019, Flora do Brasil 2020 em construção.:, http://reflora.jbrj.gov.br/reflora/listaBrasil (accessed January 2019).

Ribeiro, A., 2002, Dinâmica paleoambiental da vegetação e clima durante o Quaternário tardio em domínios da mata Atlântica, brejo do semiárido e cerrado nordestinos, utilizando isótopos do carbono da matéria orgânica do solo e das plantas: Universidade de São Paulo, 193 p.

Ricklefs, R., 2003, A economia da natureza: Rio de Janeiro, Editora Guanabara Koogan, $570 \mathrm{p}$.

Rodal, M.J.N., Martins, F.R., and Sampaio, E.V.S.B., 2008, Levantamento quantitativo das plantas lenhosas em trechos de vegetação de caatinga em Pernambuco: Caatinga, v. 21, p. 192-205.

Rodal, M.J.N., Nascimento, L.M., and Melo, A.L., 1999, Composição florística de um trecho de vegetação arbustiva caducifólia, no município de lbimirim, PE, Brasil: Acta Botanica Brasilica, v. 13, p. 15-28, doi:10.1590/S010233061999000100003.

Rodal, M.J.N., Sales, M.F., and Mayo, S.J., 1998, Floresta serrana: localização e conservação dos remanescentes brejos de altitude em Pernambuco: Recife, Imprensa Universitária - Universidade Federal Rural de Pernambuco, $37 \mathrm{p}$.

Roubik, D.W., and Moreno Patiño, J., 1991, Pollen and spores of Barro Colorado Island: St. Louis - Missouri, Missouri Botanical Garden, 270 p.

Round, F.E., Crawford, R.M., and Mann, D.G., 1990, The diatoms: biology \& morphology of the genera: Cambridge, Cambridge University Press, $747 \mathrm{p}$.

Rule, S., Brook, B.W., Haberle, S.G., Turney, C.S.M., Kershaw, A.P., and Johnson, C.N., 2012, The aftermath of megafaunal extinction: Ecosystem transformation in Pleistocene Australia: Science, v. 335, p. 1483-1486, 
doi:10.1126/science.1214261.

Runge, F., 1999, The opal phytolith inventory of soils in central Africa - Quantities, shapes, classification, and spectra: Review of Palaeobotany and Palynology, v. 107, p. 23-53, doi:10.1016/S0034-6667(99)00018-4.

Sales, M.F., Mayo, S.J., and Rodal, M.J.N., 1998, Plantas vasculares das florestas serranas de Pernambuco: Um checklist da flora ameaçada dos brejos de altitude, Pernambuco, Brasil: Recife, Universidade Federal Rural de Pernambuco, 130 p. Salgado-Labouriau, M.L., 1973, Contribuição à palinologia dos cerrados: Rio de Janeiro, Academia Brasileira de Ciências, 291 p.

Salgado-Labouriau, M.L., 1994, História ecológica da Terra: São Paulo, E. Bücher, $1994 \mathrm{p}$.

Salgado-Labouriau, M.L., Barberi, M., Ferraz-Vicentini, K.R., and Parizzi, M.G., 1998, A dry climatic event during the late Quaternary of tropical Brazil: Review of Palaeobotany and Palynology, v. 99, p. 115-129, doi:10.1016/S00346667(97)00045-6.

Sánchez, B., Prado, J.L., and Alberdi, M.T., 2004, Feeding ecology , dispersal , and extinction of South American Pleistocene gomphotheres (Gomphotheriidae , Proboscidea ): Paleobiology, v. 30, p. 146-161.

Santana, J.A.D.S., Santana Júnior, J.A.S., Barreto, W.D.S., and Ferreira, A.T.D.S., 2016, Estrutura e distribuição espacial da vegetação da Caatinga na Estação Ecológica do Seridó, RN: Pesquisa Florestal Brasileira, v. 36, p. 355-361, doi:10.4336/2016.pfb.36.88.1002.

Santos, M.P.D., 2004, As comunidades de aves em duas fisionomias da vegetação de Caatinga no estado do Piauí, Brasi: Ararajuba, v. 12, p. 113-123, doi:10.1039/cs9790800563.

Schmitz, P.I., 1987, Prehistoric Hunters and Gatherers of Brazil: Journal of World Prehistory, v. 1, p. 53-136.

Schneider, T., Bischoff, T., and Haug, G.H., 2014, Migrations and dynamics of the intertropical convergence zone: Nature, v. 513, p. 45-53, doi:10.1038/nature13636.

Schnitzer, S.A., and Carson, W.P., 2001, Treefall gaps and the maintenance of species diversity in a tropical forest: Ecology, v. 82, p. 913-919, doi:https://doi.org/10.1890/0012-9658(2001)082.

Schoeninger, M.J., and DeNiro, M.J., 1984, Nitrogen and carbon isotopic composition 
of bone collagen from marine and terrestrial animals: Geochimica et Cosmochimica Acta, v. 48, p. 625-639.

Schultz, A., 1985, Introdução à Botânica Sistemática: Univ. Fed. Rio G. Sul. NBS., 414 p.

Scott, A.C., and Damblon, F., 2010, Charcoal: Taphonomy and significance in geology, botany and archaeology: Palaeogeography, Palaeoclimatology, Palaeoecology, v. 291, p. 1-10, doi:10.1016/j.palaeo.2010.03.044.

Silva, V.P., 2010, Distúrbios Ondulatórios de Leste: estudo de casos que afetaram a costa leste do NEB: Universidade Federal de Campina Grande, 77 p.

Silva, F.M., 2009, Mamíferos do Pleistoceno Superior de Afrânio, Pernambuco, nordeste do Brasil: Universidade Federal de Pernambuco, 107 p.

Silva, J.L.L., 2008, Reconstituição paleoambiental baseada no estudo de mamíferos pleistocênicos de Maravilha e Poço das Trincheiras, Alagoas, nordeste do Brasil: Universidade Federal de Pernambuco, $229 \mathrm{p}$.

Silva, J.L.L., 2001, Tafonomia em mamíferos pleistocênicos: caso da planície colúvioaluvionar de Maravilha - AL: $99 \mathrm{p}$.

Silva De Lucena, M., Alves, A.R., and Bakke, I.A., 2017, Regeneração natural da vegetação arbóreo-arbustiva de Caatinga em face de duas formas de uso: Agropecuária Científica no Semiárido, v. 13, p. 212-222, http://revistas.ufcg.edu.br/acsa/index.php/ACSA/index.

Silva, F.H.M., Santos, F.A.R., and Lima, L.C.L., 2016, Flora polínica das caatingas: Estação Ecológica de Canudos - Canudos, Bahia, Brasil: Feira de Santana Bahia, Micron Bahia, $120 \mathrm{p}$.

Smith, B.N., and Epstein, S., 1971, Two Categories of 13C/12C Ratios for Higher Plants: Plant Physiology, v. 47, p. 380-384, doi:10.1104/pp.47.3.380.

Souza, J.A.N., and Rodal, M.J.N., 2010, Levantamento florístico em trecho de vegetação ripária de caatinga no Rio Pajeú, Floresta/Pernambuco-Brasil: Caatinga, v. 23, p. 54-62.

Stockmarr, J., 1971, Tablets with spores in absolute pollen analysis: Pollen et Spores, v. 13, p. $615-621$.

Stuiver, M., Reimer, P.J., and Reimer, C.W., 2017, CALIB 7.1: WWW program, http://calib.org (accessed September 2017).

Stute, M., Forster, M., Frischkorn, H., Serejo, A., Clark, J.F., Schlosser, P., Broecker, W.S., and Bonani, G., $1995 \mathrm{a}$, Cooling of tropical Brazil $\left(5^{\circ} \mathrm{C}\right)$ during the last glacial 
maximum: Science, v. 269, p. 379-383, doi:10.1126/science.269.5222.379.

Stute, M., Forster, M., Frischkorn, H., Serejo, A., Clark, J.F., Schlosser, P., Broecker, W.S., and Bonani, G., $1995 \mathrm{~b}$, Cooling of tropical Brazil $\left(5^{\circ} \mathrm{C}\right)$ during the last Glacial Maximum: Science, v. 269, p. 379-383.

Suguio, K., Barreto, A.M.F., De Oliveira, P.E., Bezerra, F.H.R., and Vilela, M.C.S.H., 2013, Indicators of Holocene sea level changes along the coast of the states of Pernambuco and Paraíba, Brazil: Geologia USP - Serie Cientifica, v. 13, p. 141152, doi:10.5327/Z1519-874X201300040008.

Talbot, M.R., and Johannessen, T.A., 1992, High resolution paloclimatic record from the last 27,500 years in the tropical West Africa from the carbon and nitrogen isotopic composition of lacustrine organic matter: Earth and Planetary Science Letters, v. 100, p. 23-37.

Tatumi, S.H., Oliveira, E., Ferreira, T., Yee, M., Brito, T.M.F., Bélo, P., and Rocca, R.R., 2015, OSL and FTIR -VIS Spectroscopy Analysis of Mammal-Bearing Pleistocene Deposits: International Journal of Luminescence and Applications, v. 5, p. 36-40.

Teles, M.M.F., Andrade, A.P., and Rosa, P.R.O., 2006, Delimitação espacial da vegetação do município de São João do Cariri - PB através de classificação de imagem orbital: Geografia - UEL, v. 15, p. 81-93.

Temóteo, J.W.C., 2000, Base municipal de informações das águas subterrâneas: Município de Ibimirim - PE: Hidrogeologia. Informações Básicas.

Tibby, J., 2001, Diatoms as indicators of sedimentary processes in Burrinjuck reservoir, New South Wales, Australia: Quater, v. 83-85, p. 245-256.

Tolonen, K., 1986, Charred particule analyses, in Berglund, B.E. ed., Handbook of Holocene Palaeocology and Palaeohydrology, New York, John Wiley and Sons Ltd., p. 485-490.

Traverse, A. (Ed.), 2005, Sedimentation of organic particles: Cambridge University Press.

Trovão, D., Silva, S., Silva, A., and Vieira Júnior, R., 2004, Estudo comparativo entre três fisionomias de caatinga no estado da Paraíba e análise do uso das espécies vegetais pelo homem nas áreas de estudo: Revista Biologia e Ciências da Terra, v. 4, http://eduep.uepb.edu.br/rbct/sumarios/pdf/estudocomparativo.pdf.

Utida, G., 2016, Variações paleoambientais e paleoclimáticas durante o Holoceno no rio Grande do Norte a partir do estudo de registros geoquímicos de sedimentos 
de lagos e cavernas: Universidade de São Paulo, 182 p.

Viana, J.C.C., Sifeddine, A., Turcq, B., Albuquerque, A.L.S., Moreira, L.S., Gomes, D.F., and Cordeiro, R.C., 2014, A late Holocene paleoclimate reconstruction from Boqueirão Lake sediments , northeastern Brazil: Palaeogeography, Palaeoclimatology, Palaeoecology, v. 415, p. 117-126, doi:10.1016/j.palaeo.2014.07.010.

Viana, M.S.S., Silva, J.L.L., Oliveira, P.V., and Julião, M.S. da S., 2011, Hábitos alimentares em herbívoros da megafauna pleistocênica no Nordeste do Brasil: Estudos Geológicos, v. 21, p. 89-95.

De Vivo, M., and Carmignotto, A.P., 2004, Holocene vegetation change and the mammal faunas of South America and Africa: Journal of Biogeography, v. 31, p. 943-957, doi:10.1111/j.1365-2699.2004.01068.x.

Vogel, J.C., 1980, Fractionation of the carbon isotopes during photosynthesis: New York, Springer Verlag, $29 \mathrm{p}$.

Vuille, M., Burns, S.J., Taylor, B.L., Cruz, F.W., Bird, B.W., Abbott, M.B., Kanner, L.C., Cheng, H., and Novello, V.F., 2012, A review of the South American monsoon history as recorded in stable isotopic proxies over the past two millennia: Climate of the Past, v. 8, p. 1309-1321, doi:10.5194/cp-8-1309-2012.

Wang, X., Auler, A.S., Edwards, R.L., and Cheng, H., 2004, Wet periods in northeastern Brazil over the past 210 kyr linked to distant climate anomalies: $\mathrm{v}$. 432, p. 2767-2769.

Wang, X., Auler, A.S., Edwards, R.L., Cheng, H., Ito, E., and Solheid, M., 2006, Interhemispheric anti-phasing of rainfall during the last glacial period: Quaternary Science Reviews, v. 25, p. 3391-3403, doi:10.1016/j.quascirev.2006.02.009.

Wang, X., Cruz, F.W., Auler, A.S., Cheng, H., and Edwards, R.L., 2008, Millennialscale climate variability recorded in Brazilian speleothems: PAGES News, v. 16, p. 31-32.

Watling, J., and Iriarte, J., 2013, Phytoliths from the coastal savannas of French Guiana: Quaternary International, v. 287, p. 162-180, doi:10.1016/j.quaint.2012.10.030.

Watling, J., Iriarte, J., Mayle, F.E., Schaan, D., Pessenda, L.C.R., Loader, N.J., StreetPerrott, F.A., Dickau, R.E., Damasceno, A., and Ranzi, A., 2017, Impact of preColumbian "geoglyph" builders on Amazonian forests: Proceedings of the National Academy of Sciences, v. 114, p. 1868-1873, doi:10.1073/pnas.1614359114. 
Watling, J., Iriarte, J., Whitney, B.S., Consuelo, E., Mayle, F., Castro, W., Schaan, D., and Feldpausch, T.R., 2016, Differentiation of neotropical ecosystems by modern soil phytolith assemblages and its implications for palaeoenvironmental and archaeological reconstructions II: Southwestern Amazonian forests: Review of Palaeobotany and Palynology, v. 226, p. 30-43, doi:http://dx.doi.org/10.1016/j.revpalbo.2015.12.002.

Wroe, S., Field, J., Fullagar, R., and Jermin, L.S., 2004, Megafaunal extinction in the late Quaternary and the global overkill hypothesis: Alcheringa: An Australasian Journal of Palaeontology, v. 28, p. 291-331, doi:10.1080/03115510408619286. 

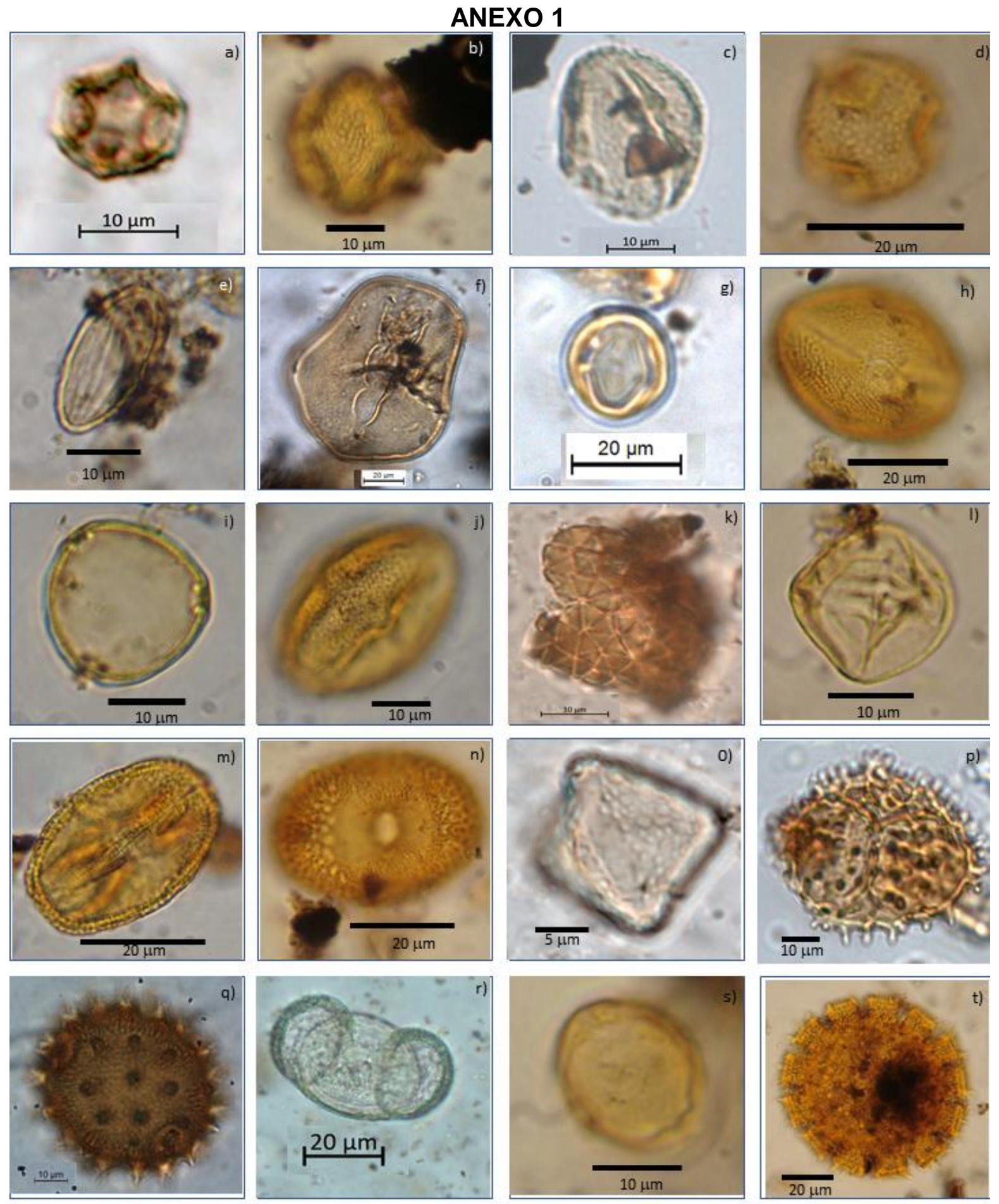

Palinomorfos representativos. Amaranthaceae: a) Alternanthera; Anacardiaceae: b) Astronium; c) Myracrodruon; Apocynaceae: d) Tabernaemontana; Araceae: e) Spathiphyllum; Arecaceae: f) Attalea (Orbignya); Begoniaceae: g) Begonia; Brassicaceae: h) Capparis; Cannabaceae: i) Celtis; Euphorbiaceae: k) Croton; j) Sapium; Fabaceae: n) Caesalpinia; m) Centrolobium; I) Copaifera; o) Peltogyne; Gentianaceae: p) Chelonanthus; Malvaceae: q) Sidastrum; r) Podocarpaceae: Podocarpus; Rhamnaceae: s) Ziziphus; Rubiaceae: t) Richardia. 

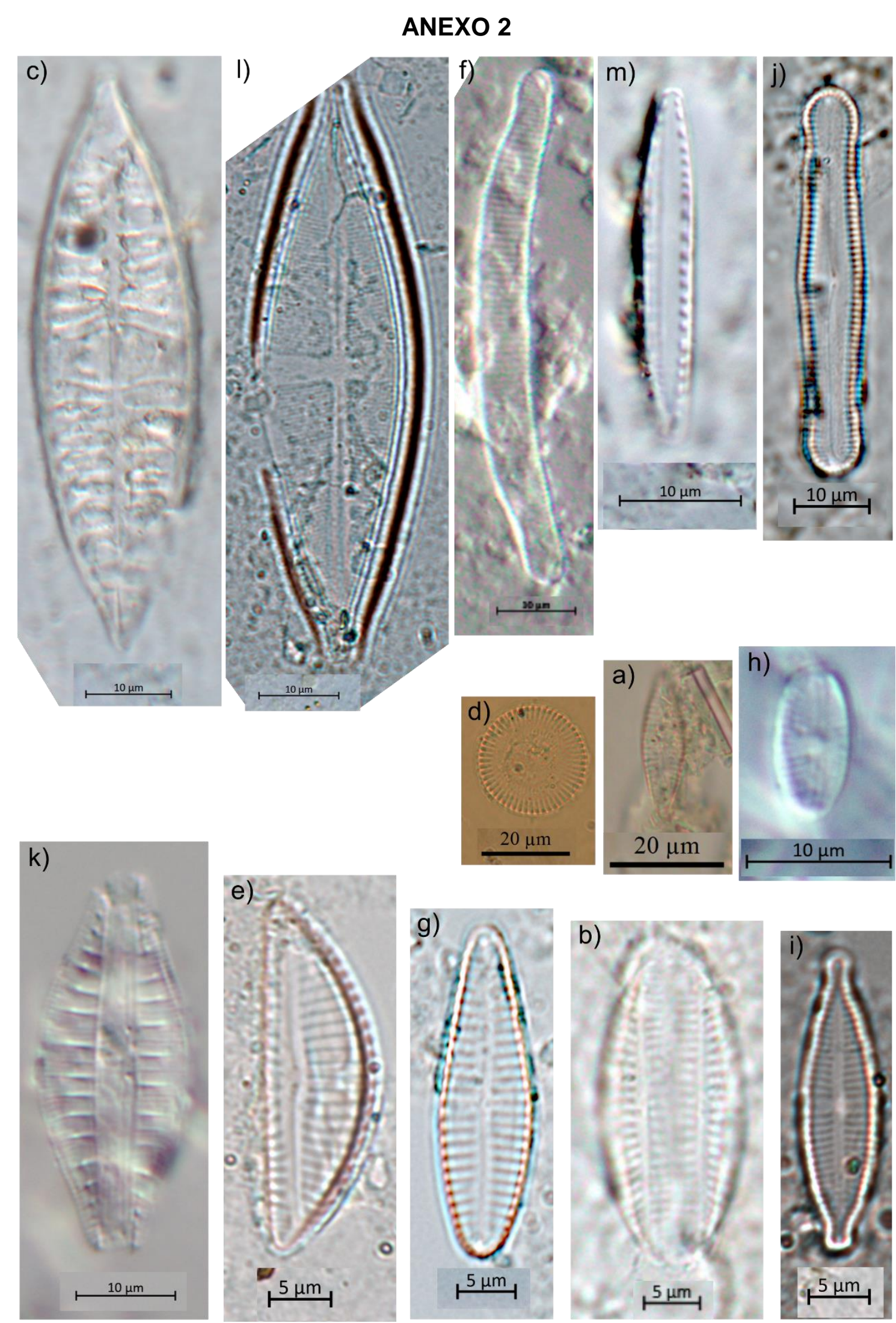

Diatomáceas identificadas: a) Achnantes deflexa; b) Amphora sp; c) Craticula cuspidata; d) Cyclotella; e) Cymbella; f) Eunotia; g) Gomphonema; h) Luticola mutica; i) Navicula; j) Pinnularia; k) Rhopalodia; I) Stauroneis; m) Synedra. 

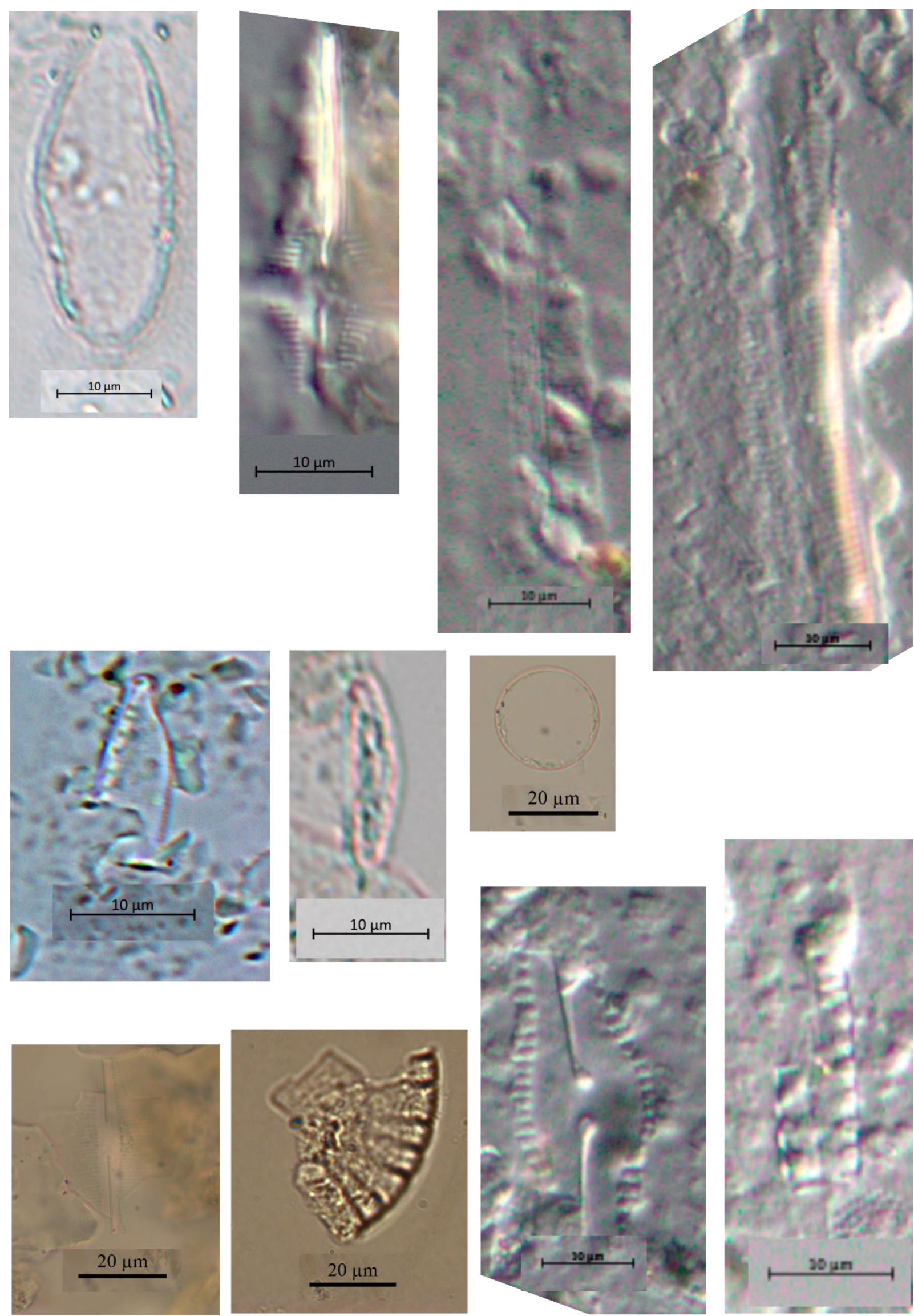

Diatomáceas quebradas e dissolvidas. 
ANEXO 3
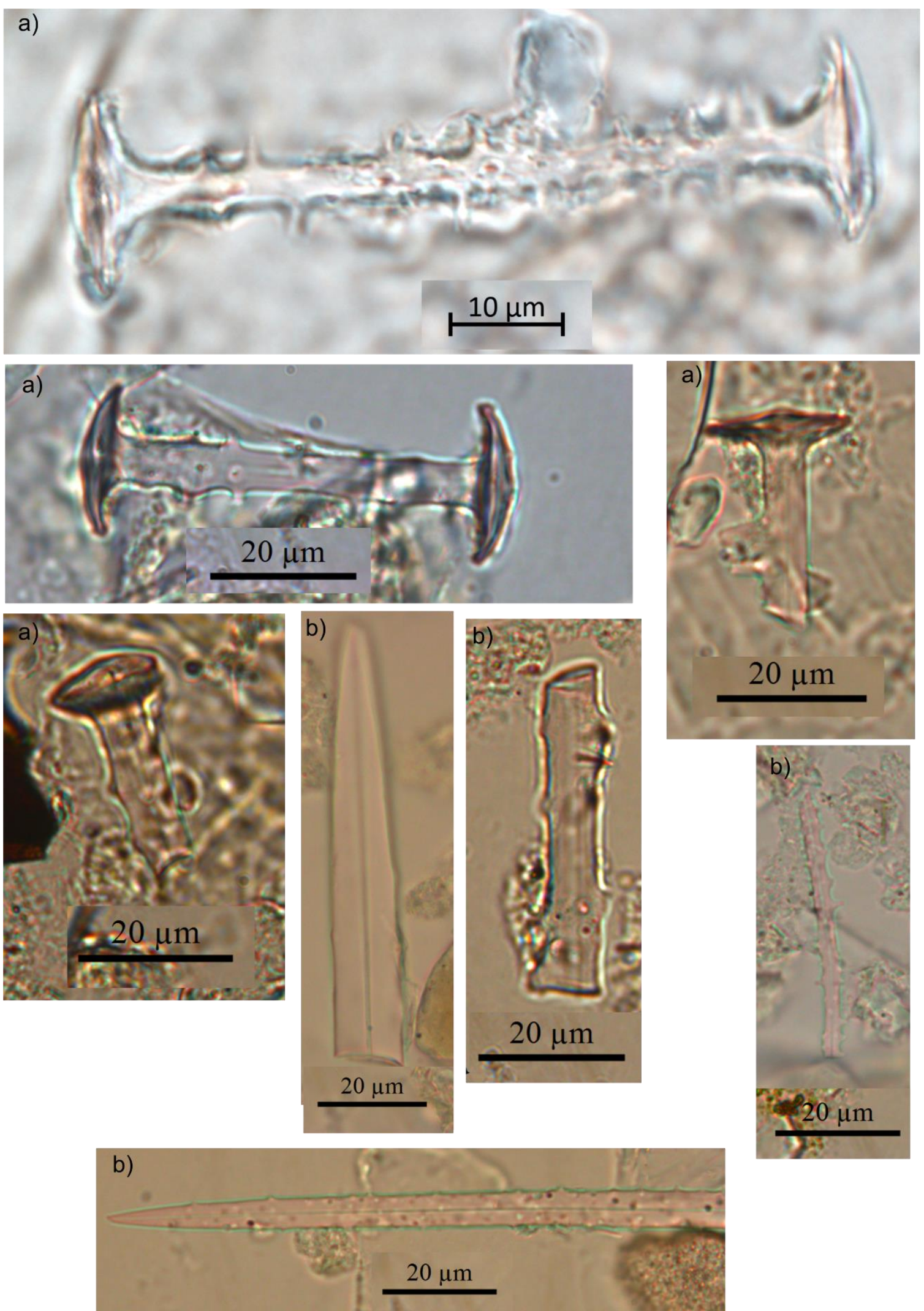

Espículas de esponja: a) Gemoscleras; b) Acanthóstilos 


\section{ANEXO 4}

Relação dos táxons identificados neste trabalho e sua correspondente distribuição para a região NEB, segundo a literatura. Afr: Afrânio; SBU: São Bento do Una; Cat: Vale do Catimbau- Buíque; SJC: São João do Cariri; PE: Pernambuco; PB: Paraíba; RN: Rio Grande do Norte; BA: Bahia; PI: Piauí; CE: Ceará; MA: Mata Atlântica; AM: Floresta Amazônica. 1 - Aguiar et al. (2003); 2 - Alcoforado-Filho et al. (2003); 3 - Souza e Rodal (2010); 4 - Trovão et al. (2004); 5 - Rodal et al. (2008); 6 - Moreira et al. (2006); 7 - Santos (2004); 8 - Albuquerque et al. (1982); 9 - Giulietti et al. (2004); 10 - Amorim et al. (2005); 11 - Santana et al. (2016); 12 - Lucena et al. (2017); 13 - Brand et al. (2015); 14 - Lima e Coelho (2018); 15 - Lemos e Rodal (2002); 16 - JBRJ (2019).

\begin{tabular}{|c|c|c|c|c|c|c|c|c|c|c|c|c|c|c|c|c|c|c|c|c|c|c|c|}
\hline & & PE & & PB & & & 1 & & 2 & 3 & 4 & 5 & 6 & 7 & 8 & 9 & 10 & 11 & 12 & 13 & 14 & 15 & 16 \\
\hline Taxa & Afr & SBU & Cat & SJC & $\mathrm{PE}$ & $\mathrm{RN}$ & PB & $\mathrm{BA}$ & $\mathrm{PE}$ & $\mathrm{PE}$ & PB & $\mathrm{PE}$ & $\mathrm{PE}$ & $\mathrm{Pl}$ & $\mathrm{PE}$ & $\mathrm{BA}$ & $\mathrm{RN}$ & $\mathrm{RN}$ & $\mathrm{RN}$ & $\mathrm{Pl}$ & $\mathrm{CE}$ & $\mathrm{PI}$ & \\
\hline Acalypha & & $X$ & & & & & & & $x$ & $X$ & & & & & & & & & & & & & \\
\hline Acanthaceae & $X$ & $X$ & & $x$ & $X$ & & & & $x$ & $x$ & & & & & & & & & & & & & \\
\hline Agarista & $X$ & & & & & & & & & & & & & & & & & & & & & & MA \\
\hline Alchornea & $x$ & & & $x$ & & & & & & & & & & & & & & & & & & & \\
\hline Alismataceae & $X$ & & & & & & & & & & & & & & & & & & & & & & \\
\hline Alternanthera & $X$ & $X$ & $X$ & $x$ & & & & $x$ & & $\mathrm{X}$ & & & $\mathrm{X}$ & & & & & & & & & & \\
\hline Amaranthaceae & & & $X$ & & & & & $x$ & $x$ & $X$ & & & $X$ & & & & & & & & & & \\
\hline Amaranthus & & $x$ & & $x$ & & & & & & $x$ & & & & & & & & & & & & & \\
\hline Anacardiaceae & & $x$ & & & & & & & $x$ & $x$ & $X$ & $X$ & $x$ & $X$ & $x$ & $x$ & & & & & $\mathrm{X}$ & & \\
\hline Annonaceae & $x$ & & & & & & & & & & & & $x$ & & & $x$ & & & & $X$ & & $\mathrm{X}$ & \\
\hline Anthurium & & & $X$ & & & & & & $\mathrm{X}$ & & & & & & & & & & & & & & \\
\hline Aphelandra & & $X$ & & & & & & & & & & & & & & & & & & & & & \\
\hline Apiaceae & & $x$ & $X$ & & & & & & & & & & & & & & & & & & & & \\
\hline Apocynaceae & $X$ & $x$ & $x$ & $x$ & & & & & & $x$ & $x$ & $x$ & & & $x$ & $X$ & $\mathrm{X}$ & $x$ & $X$ & $X$ & $x$ & $X$ & \\
\hline Aptandra & & & $x$ & & & & & & & & & & & & & & & & & & & & AM \\
\hline Araceae & $x$ & $X$ & $x$ & $x$ & & & & & $x$ & & & & & & & & & & & & & & \\
\hline Arecaceae & $X$ & $X$ & $X$ & $x$ & & & & & & & & & & & & $X$ & & & & & & & \\
\hline Asteraceae & $X$ & $X$ & & $x$ & & & & & $X$ & $X$ & & & & & & $X$ & & & & & & & \\
\hline Asteraceae arb. & & $X$ & $X$ & & & & & & $X$ & & & & & & & & & & & & & & \\
\hline Astrocaryum & $X$ & & & & & & & & & & & & & & & & & & & & & & \\
\hline Astronium & & & $X$ & & & & & & & & & & $X$ & $X$ & $X$ & & & & & & & & \\
\hline Balfourodendron & & $x$ & & & & & & & & & & & & & & $x$ & & & & & & & \\
\hline Bauhinia & & & $X$ & & & & & & $x$ & & $\mathrm{X}$ & $x$ & & & $X$ & $x$ & $X$ & $x$ & & $X$ & $X$ & $X$ & \\
\hline
\end{tabular}


Continuação ....

\begin{tabular}{|c|c|c|c|c|c|c|c|c|c|c|c|c|c|c|c|c|c|c|c|c|c|c|}
\hline Begonia & & $\mathrm{x}$ & & & & & & $x$ & & & & & & & $x$ & & & & & & & \\
\hline Bignoniaceae & $\mathrm{x}$ & & & & $x$ & & $\mathrm{X}$ & $\mathrm{X}$ & $\mathrm{X}$ & $\mathrm{x}$ & $\mathrm{x}$ & $x$ & & $x$ & $\mathrm{x}$ & $\mathrm{x}$ & $\mathrm{x}$ & & $x$ & $\mathrm{x}$ & & \\
\hline Bombacaceae & & $\mathrm{x}$ & & & & & & $x$ & & $x$ & $x$ & $x$ & & $x$ & $x$ & & & & & $x$ & & \\
\hline Boraginaceae & $\mathrm{x}$ & & & & & & & $x$ & $x$ & & $x$ & $x$ & & $x$ & $x$ & $\mathrm{x}$ & & & $x$ & $x$ & $\mathrm{X}$ & \\
\hline Borreria & $x$ & $\mathrm{x}$ & $x$ & & & & & & & & & & & & & & & & & & & \\
\hline Bredemeyera & & $x$ & & & & & & & & & & & & & & & & & & & & \\
\hline Bromeliaceae & & $x$ & & & & & & $x$ & $x$ & & & & $\mathrm{x}$ & & $x$ & & & & & & & \\
\hline Byrsonima & & $x$ & $x$ & & & & $\mathrm{x}$ & & & & & & & & $x$ & & & & $x$ & & $\mathrm{x}$ & \\
\hline Cactaceae & & $x$ & & & & & & $\mathrm{x}$ & $\mathrm{x}$ & & $x$ & & $x$ & $x$ & $x$ & & $x$ & & & $x$ & $x$ & \\
\hline Caesalpinia & & & $x$ & & $\mathrm{x}$ & $x$ & $x$ & $\mathrm{X}$ & $\mathrm{X}$ & $\mathrm{x}$ & $x$ & $x$ & $\mathrm{x}$ & $\mathrm{X}$ & $\mathrm{x}$ & $\mathrm{X}$ & & & $\mathrm{X}$ & & & \\
\hline Calycophyllum & & & $\mathrm{x}$ & & & & & & & & & & & & & & & & & & & AM \\
\hline Capparis & & & $x$ & & & & & $\mathrm{X}$ & $\mathrm{X}$ & & $\mathrm{x}$ & $\mathrm{X}$ & & & $\mathrm{x}$ & $\mathrm{X}$ & & & & & & \\
\hline Caryocar & & & $x$ & $\mathrm{x}$ & & & & & & & & & & & & & & & & & & \\
\hline Casearia & $\mathrm{x}$ & $\mathrm{x}$ & $x$ & & & & & $\mathrm{X}$ & & & & & & & & & & & $x$ & & & \\
\hline Cassia & & $x$ & & & & & & & & & & & & $\mathrm{X}$ & $\mathrm{x}$ & & $\mathrm{x}$ & & & & & \\
\hline Cecropia & & & $\mathrm{x}$ & & & & & & & & & & & & & & & & & & & \\
\hline Celtis & & $x$ & & & & & & & $x$ & & & & & & & & & & & & & \\
\hline Centrolobium & & $x$ & & & & & & & & & & & & & $\mathrm{x}$ & & & & & & & \\
\hline Cereus & $\mathrm{X}$ & & & & & & & $\mathrm{X}$ & & & $\mathrm{x}$ & & & & $x$ & & $\mathrm{X}$ & & & $\mathrm{X}$ & $\mathrm{X}$ & \\
\hline Cheiloclinium & & $x$ & & & & & & & & & & & & & & & & & & & & \\
\hline Chelonanthus & & $x$ & & & & & & & & & & & & & & & & & & & & \\
\hline Chenopodiaceae & & & $\mathrm{X}$ & & & & & & & & & & & & & & & & & & & \\
\hline Chomelia & & $x$ & & & & & & & & & & & & & & & & & & & & \\
\hline Chorisia & & $x$ & $\mathrm{X}$ & & & & & $\mathrm{X}$ & & & & & & & $\mathrm{X}$ & & & & & & & \\
\hline Chrysobalanaceae & & $x$ & & & & & & & $\mathrm{x}$ & & & & & & $x$ & & & & & & & \\
\hline Cleome & & $x$ & & & & & & & $\mathrm{x}$ & & & & & & $x$ & & & & & & & \\
\hline Coccocypselum & & $\mathrm{x}$ & & & & & & & & & & & & & & & & & & & & \\
\hline Commelina & & $x$ & $\mathrm{X}$ & & & & $\mathrm{X}$ & $X$ & & & & $\mathrm{x}$ & & & & & & & & & & \\
\hline Commiphora & & $\mathrm{x}$ & & & & & & $\mathrm{x}$ & & $\mathrm{X}$ & $\mathrm{x}$ & & & & $X$ & $\mathrm{X}$ & $\mathrm{x}$ & $\mathrm{X}$ & & & & \\
\hline
\end{tabular}


Continuação ....

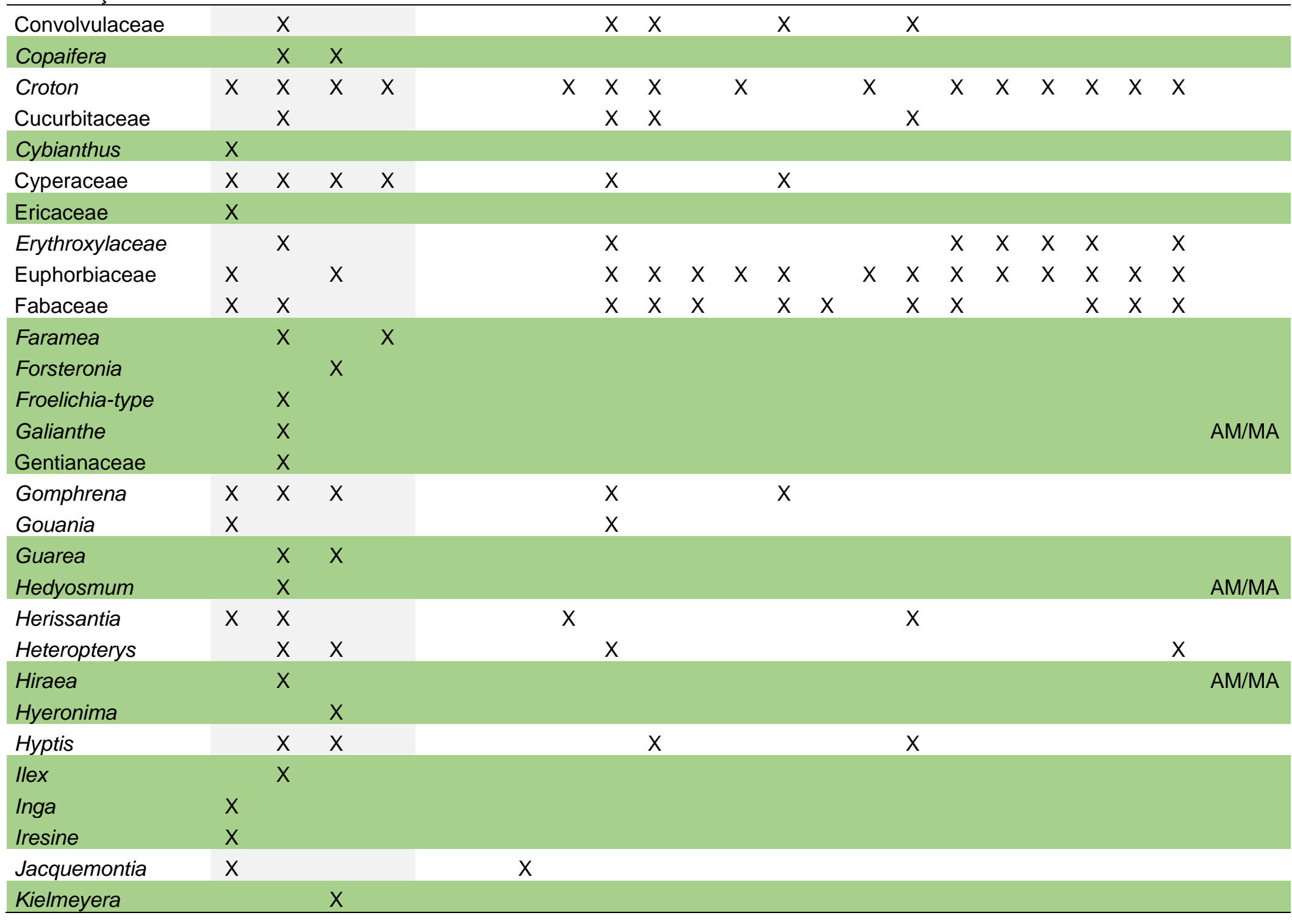


Continuação ....

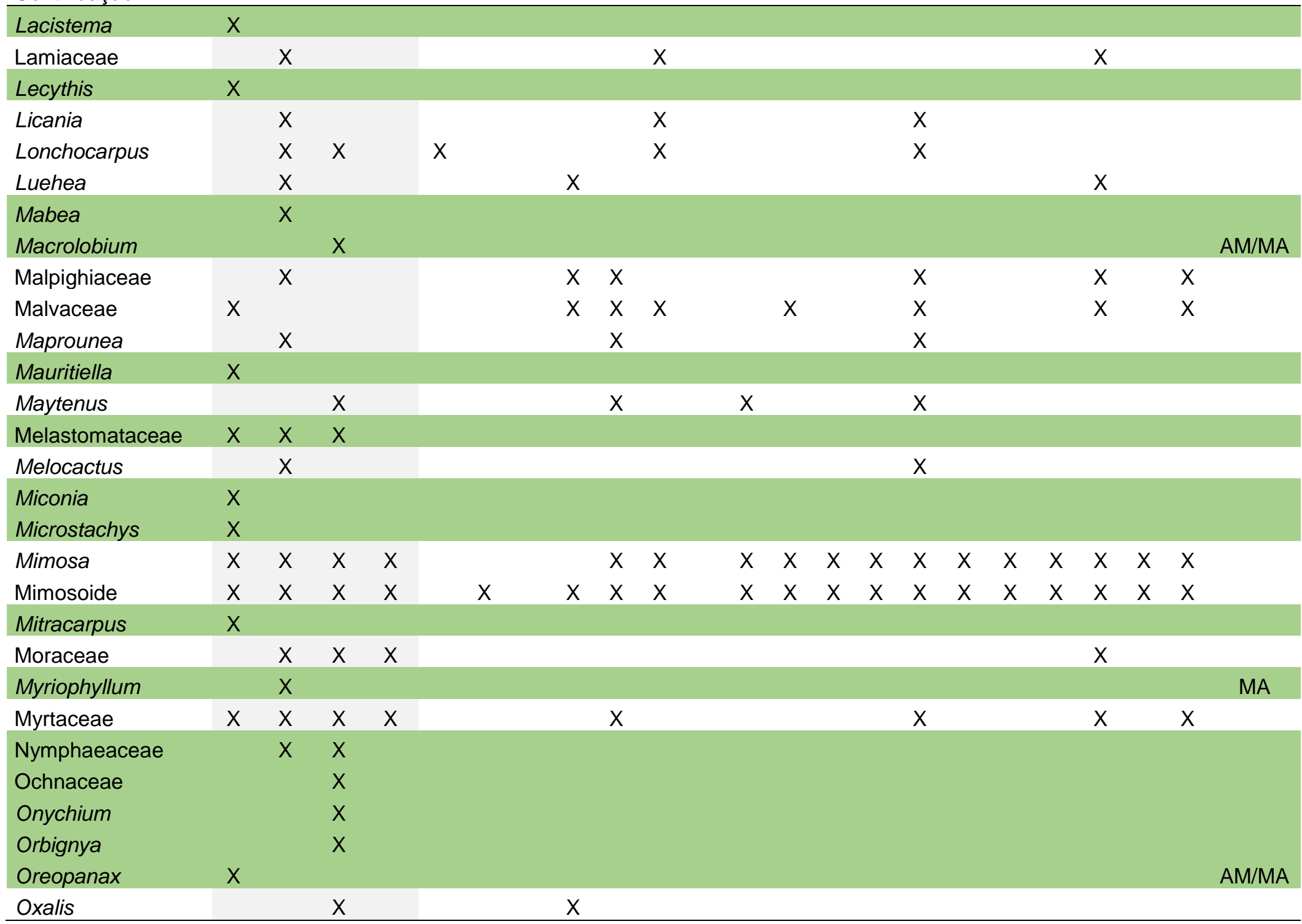


Continuação...

\begin{tabular}{|c|c|c|c|c|c|c|c|c|c|c|c|c|c|c|c|}
\hline Oxandra & $x$ & & & & & & & & & & & $\mathrm{X}$ & & & \\
\hline Parkia & $x$ & & & & & & & & & & & & & & \\
\hline Passifloraceae & & $\mathrm{X}$ & & & & $\mathrm{X}$ & & & & & & & & & \\
\hline Paullinia & $\mathrm{x}$ & & & & & & & & & & & & & & \\
\hline Peixotoa & & $\mathrm{x}$ & $x$ & & & & & & & & & & & & $\mathrm{x}$ \\
\hline Pereskia & & $x$ & & & & & & & & & & $x$ & & & \\
\hline Pinus & & & $\mathrm{x}$ & & & & & & & & & & & & \\
\hline Piperaceae & $x$ & $x$ & $x$ & & & & & & & & & & & & \\
\hline Piptadenia & & $x$ & & & & & $x$ & & & $x$ & & $\mathrm{x}$ & $x$ & $x \quad x$ & $x$ \\
\hline Poaceae & $\mathrm{x}$ & $x$ & $x$ & $x$ & & & & & & $\mathrm{X}$ & & & & & \\
\hline Podocarpus & $x$ & $x$ & & & & & & & & & & & & & \\
\hline Pouteria & & $\mathrm{x}$ & $\mathrm{X}$ & & & & & & & & & & & & \\
\hline Prosopis & & & & $\mathrm{X}$ & & & & & & $x$ & & & & & \\
\hline Protium & & $x$ & & & & & & & & & & & & & \\
\hline Psychotria & & $\mathrm{x}$ & & & & & & & & & & & & & \\
\hline Pterogyne & $\mathrm{x}$ & & & & & & & & & & & $x$ & & & \\
\hline Richardia & $x$ & $x$ & $x$ & & & & & & & & & & & & \\
\hline Roupala & & $x$ & & & & & & & & & & & & & \\
\hline Ruellia & & $x$ & & & $x$ & & $X$ & $\mathrm{X}$ & & & & & & & \\
\hline Sagittaria & & $x$ & $x$ & & & & & & & & & & & & \\
\hline Salvia & & & $\mathrm{X}$ & & & & & & & & & & & & \\
\hline Sapindaceae & & $x$ & & & & $x$ & $x$ & $x$ & & $x$ & & $\mathrm{X}$ & & & \\
\hline Sapium & $\mathrm{x}$ & $x$ & $\mathrm{x}$ & & & & $x$ & & $\mathrm{X}$ & $\mathrm{x}$ & $\mathrm{X}$ & $x$ & & & \\
\hline Schefflera & & & $x$ & & & & & & & & & & & & \\
\hline Schinus & $x$ & & & & & & & & & & & & & & \\
\hline Sciaphila & $x$ & & & & & & & & & & & & & & $\mathrm{AM} / \mathrm{MA}$ \\
\hline Scleronema & & & $\mathrm{x}$ & & & & & & & & & & & & AM \\
\hline Sebastiania & & $x$ & & & & & & & & & & $X$ & & $\mathrm{X}$ & \\
\hline Secondatia & $\mathrm{X}$ & & & & & & & & & & & & & & \\
\hline
\end{tabular}


Continuação ....

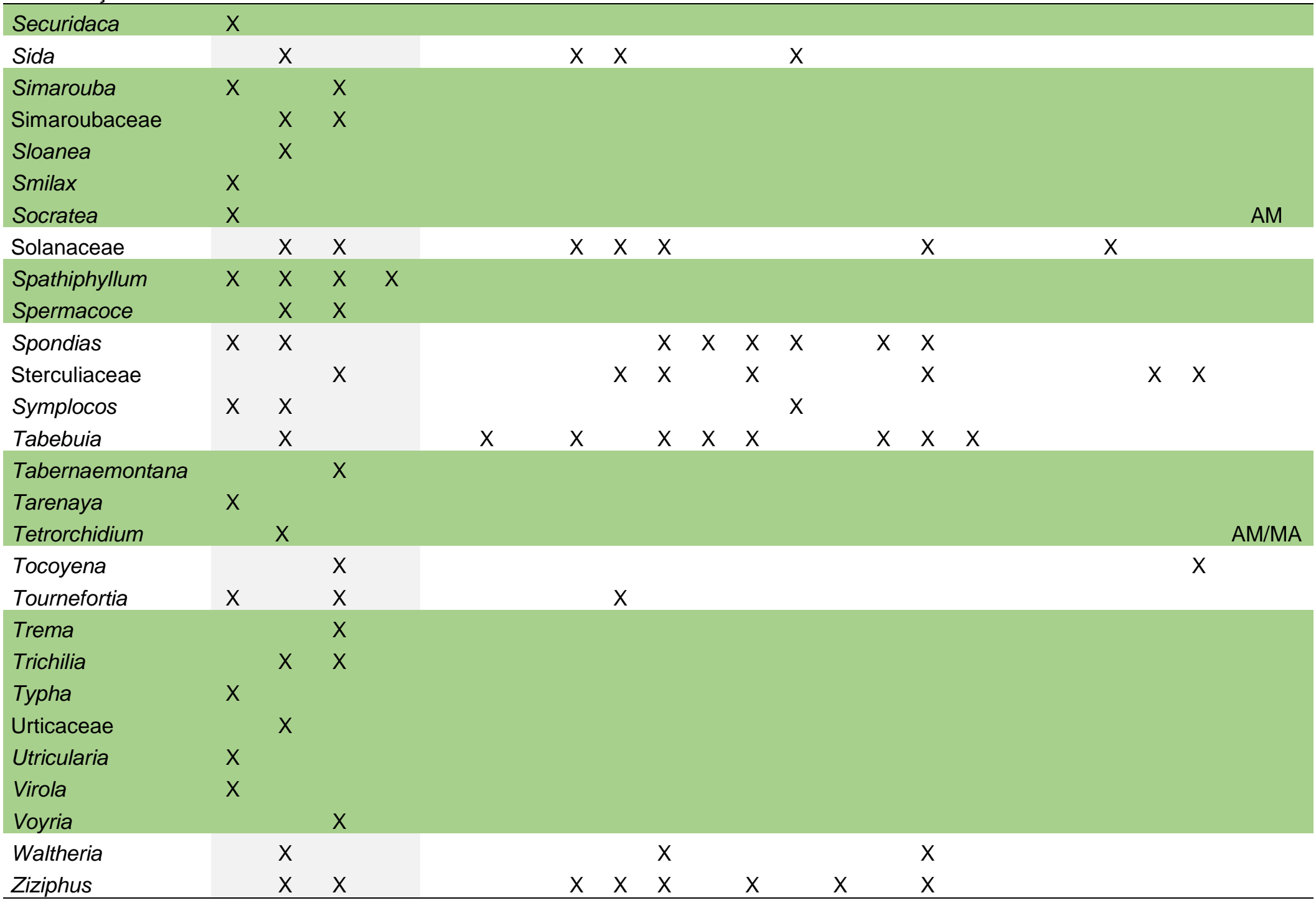

${ }^{*}$ Coluna em azul representa os táxons identificados neste trabalho e linhas verdes os não citados na literatura referenciada. 
